\title{
THE TEOTIHUACAN BURIALS AND OFFERINGS: \\ A COMMENTARY AND INVENTORY
}

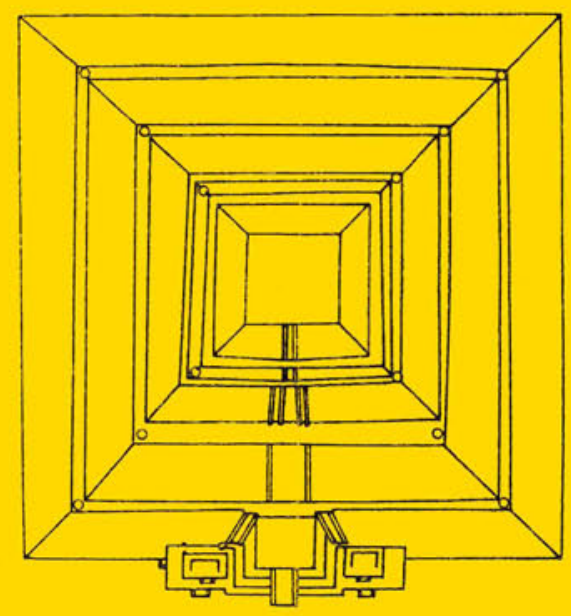

EVELYN RATTRAY

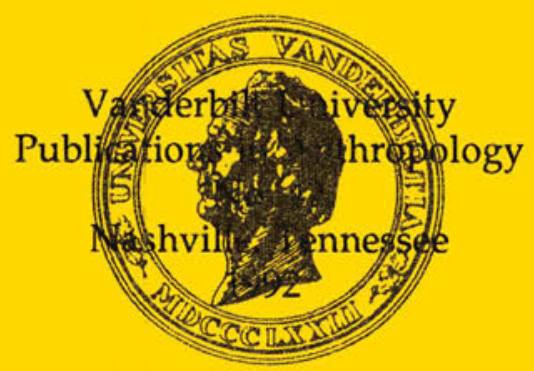




\title{
THE TEOTIHUACAN BURIALS AND OFFERINGS: A COMMENTARY AND INVENTORY
}

\author{
EVELYN RATTRAY
}

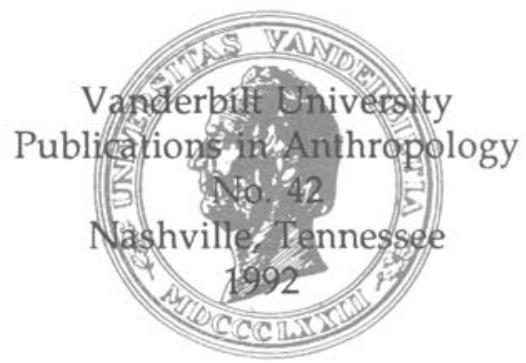




\section{VANDERBILT UNIVERSITY PUBLICATIONS IN ANTHROPOLOGY}

Vanderbilt University Publications in Anthropology are published by the Department of Anthropology, Vanderbilt University, Nashville, Tennessee. This is a consecutively numbered series devoted to the dissemination of the results of scholarly research in the field of Anthropology but without specific restriction as to content or theoretical orientation of research, geographical cencentration or institutional affiliation of the author.

Ronald Spores, Series Editor

William Fowler, Associate Editor

John D. Monaghan, Associate Editor

Renee Yoder, Assistant Editor 


\section{TABLE OF CONTENTS}

$\underline{\text { Page }}$

Acknowledgements

i

INTRODUCTION

$\begin{array}{lr}\text { Earlier Studies } & 2\end{array}$

COMMENTARY ON THE TEOTIHUACAN BURIALS 4

The Terminal Formative Period Pattern $\quad 4$

Pyramid-Temple Burials

Burials in Residential Complexes 9

La Ventilla B Temples and Patios 9

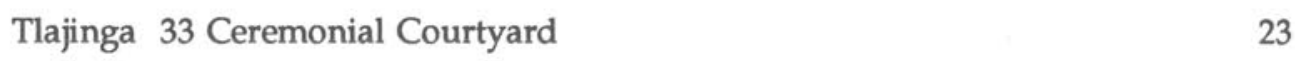

The Early Classic Period Burial Patterns $\quad 24$

La Ventilla A and B Compounds $\quad 27$

$\begin{array}{ll}\text { Tlajinga } 33 \text { Compound } & 27\end{array}$

$\begin{array}{ll}\text { The Ethnic Barrios } & 27\end{array}$

$\begin{array}{ll}\text { Oaxaca Barrio } & 39\end{array}$

Merchants' Barrio $\quad 51$

Tlamimilolpa Compound 53

Thin Orange in the Teotihuacan Burials $\quad 59$

$\begin{array}{lr}\text { The Late Classic Burial Patterns } & 59\end{array}$

$\begin{array}{ll}\text { Ethnic Barrios } & 65\end{array}$

$\begin{array}{ll}\text { Excavations and Chronology of the Teotihuacan Burials } & 71\end{array}$

$\begin{array}{ll}\text { Ostoyahualco Site Excavations } & 71\end{array}$

$\begin{array}{ll}\text { Temple of Quetzalcoatl Excavations } & 71\end{array}$

$\begin{array}{ll}\text { Ciudadela Palaces Excavations } & 72\end{array}$

$\begin{array}{ll}\text { Excavations at La Ventilla A and B Compounds } & 73\end{array}$

$\begin{array}{ll}\text { Excavations at the Tlajinga } 33 & 74\end{array}$ 
$\begin{array}{ll}\text { Oaxaca Barrio Excavations } & 75\end{array}$

$\begin{array}{ll}\text { Merchants' Barrio Excavations } & 76\end{array}$

$\begin{array}{ll}\text { Tlamimilolpa Compound } & 76\end{array}$

$\begin{array}{ll}\text { Xolalpan Compound Excavations } & 77\end{array}$

$\begin{array}{lc}\text { Tetitla Compound Excavations } & 78\end{array}$

$\begin{array}{ll}\text { Zacuala Compound Excavations } & 79\end{array}$

$\begin{array}{lc}\text { Yayahuala Compound Excavations } & 80\end{array}$

INAH Teotihuacan Project 1960-1964 80

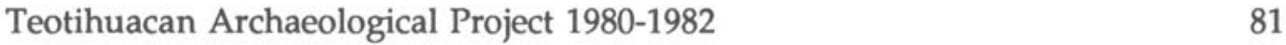

APPENDIX: THE BURIAL AND OFFERING INVENTORIES 85

$\begin{array}{lr}\text { Ostoyahualco Caches } & 87\end{array}$

$\begin{array}{lr}\text { Ostoyahualco Burials } & 89\end{array}$

$\begin{array}{ll}\text { Pueblo Perdido Burial } & 91\end{array}$

Pyramid of the Sun, Cave Offerings $\quad 92$

Temple of Quetzalcoatl Burials and Offerings $\quad 92$

Temple of Quetzalcoatl, Burials on South Side 96

$\begin{array}{lr}\text { Tlamimilolpa Compound Burials (1942) } & 97\end{array}$

$\begin{array}{ll}\text { Tlamimilolpa Compound burials (1983) } & 104\end{array}$

$\begin{array}{ll}\text { Xolalpan Compound } & 106\end{array}$

$\begin{array}{lr}\text { Extroardinary Find } & 109\end{array}$

$\begin{array}{ll}\text { La Ventilla A Compound } & 111\end{array}$

$\begin{array}{ll}\text { La Ventilla B Compound } & 116\end{array}$

$\begin{array}{lr}\text { Tetitla Compound } & 145\end{array}$

$\begin{array}{lr}\text { Zacuala Palace and Zacuala Patio Burials } & 171\end{array}$

$\begin{array}{lr}\text { Yayahuala Compound Burials } & 182\end{array}$

$\begin{array}{ll}\text { Tlajinga } 33 \text { Burials } & 186\end{array}$

$\begin{array}{ll}\text { Oaxaca Barrio Burials } & 201\end{array}$ 
Proyecto Teotihuacan 1960-1964 (INAH) Burials 222

Proyecto Arqueológico Teotihuacan 1980-1982 225

REFERENCES CITED $\quad 226$

APPENDIX:

TABLE 1. LIST OF TEOTIHUACAN BURIALS 236

TABLE 2. INDIVIDUALS IN TEOTIHUACAN BURIALS 252 


\section{LIST OF FIGURES}

Figures

$\underline{\text { Page }}$

1 Map of Teotihuacan Showing Locations of the Burials 3

2 Plans of Terminal Formative Pyramids and Temples 5

$3 \quad$ "Tlaloc Floreros" from Ostoyahualco $\quad 7$

$\begin{array}{lll}4 & \text { Temple of Quetzalcoatl, Burial } 190 & 7\end{array}$

$5 \quad$ Plans of Terminal Formative Temples and Courtyards $\quad 10$

6 Plan of La Ventilla B Compound 13

$7 \quad$ Examples of Burial Positions at La Ventilla B 14

$8 \quad$ Plan of Tlajinga 33 Compound 22

9 Bird Effigy from Burial 66, La Ventilla B 25

10 Early Tlamimilolpa Bowl Offerings 26

11 Plan of Excavations at the Oaxaca Barrio: 28

University of the Americas and Teotihuacan Mapping Project

12 Oaxaca Barrio, Burials A1, A2, A3, A4 29

13 Oaxaca Barrio Monte Alban II-IIIA Urn 30

14 Oaxaca Barrio: South Profile and Plan of E1N17, Skull Burial C 31

15 Merchants' Barrio, Plan of Xocotitla 40

16 Merchants' Barrio, Plan of Mezquititla 41

17 Merchants' Barrio, Plan of Nopalera 42

18 Merchants' Barrio, Plan of Late Tlamimilolpa Burials 22 and $23 \quad 43$

19 Merchants' Barrio: Shrine 2, Burials 14, 17 and $18 \quad 48$

20 Merchants' Barrio: Shrine 3, Circular Structure 12 Burials 49

21 Merchants' Barrio, Early Xolalpan Offerings 50

22 Plan of Tlamimilolpa Compound 54

23 Plan of Excavations at Tlamimilolpa in 1983

24 Plan and Profile of Burial 1-'83 56 
25 Plan of Tetitla, Level 3

26 Plan of Tetitla, Level 2

27 Plan of Zacuala Patios

28 Plan of Zacuala Palace

66

29 Plan of Yayahuala Compound

30 Plan of Xolalpan Compound 


\section{LIST OF PLATES}

$\underline{\text { Plate }}$

$\underline{\text { Page }}$

I $\quad$ Pueblo Perdido Burial Offering, Early Tzacualli Phase 8

II Ostoyahualco Tlaloc Vases, Early Tzacualli Phase 11

III La Ventilla B , Burial 16, Early Tlamimilolpa Phase 15

IV La Ventilla B Burial 21, Early Tlamimilolpa Phase 16

$\begin{array}{ll}\text { V La Ventilla B Burial 73, Early Tlamimilolpa Phase } & 17\end{array}$

$\begin{array}{ll}\text { VI La Ventilla B Salvage Burial III, Early Tlamimilolpa Phase } & 18\end{array}$

VII La Ventilla B Burial 100, Early Tlamimilolpa Phase 19

VIII La Ventilla B Burial 110, Early Tlamimilolpa Phase 20

IX La Ventilla B Burial 66, Late Tlamimilolpa Phase 32

X Cylindrical Vase "Kaminaljuyu Style", Early Xolalpan Phase 33

XI "Terrazas Lustroso" Bowl, El Tajin Import 34

XII Lustrous Ware Vase with Lid, Late Tlamimilolpa Phase 35

XIII Monte Albán II-IIIA Urn from Oaxaca Barrio 36

XIV Late Xolalpan Funerary Offering from Oaxaca Barrio 37

$\begin{array}{lll}\text { XV Early Xolalpan Incensario from Oaxaca Barrio } & 38\end{array}$

XVI Early Xolalpan Round Houses at Xocotitla 44

XVII Late Xolalpan Burial 17 Skeleton, Xocotitla 45

XVIII Late Xolalpan Burials 10-12, Circular Structure 4, Xocotitla 46

$\begin{array}{ll}\text { XIX Late Tlamimilolpa Burial } 22 \text { from Mezquititla } & 47\end{array}$

$\begin{array}{ll}\text { XX Late Xolalpan Incensario } & 60\end{array}$

XXI Metepec Thin Orange Vase with Moldmade Applique 61

XXII Thin Orange Human Effigy Jar from Kaminaljuyu 62

XXIII Late Xolalpan Phase Multiple Burial, INAH Project 80-82 63

$\begin{array}{lll}\text { XXIV Tetitla, Southeast Temple Group } & 69\end{array}$

XXV Yayahuala, Main Plaza with 4-Temple Complex 69 


\section{ACKNOWLEDGEMENTS}

This inventory of the Teotihuacan burials has been in preparation since 1978 as a sideline to my work on the Teotihuacan Ceramic Chronology which I started as a member of the Teotihuacan Mapping Project (1966-1969) and continued at the Instituto de Investigaciones Antropológicas of the National University of Mexico (1974 to the present). The Instituto de Investigaciones Antropológicas provided the financial support for the excavations at the Merchants' Barrio, Teotihuacan. Permits to excavate at the Merchants' Barrio were kindly granted by Ingeniero García Barcenas head of the Instituto Nacional de Antropología e Historia. I take this opportunity to express my thanks to members of both these Institutions for their assistance.

The cataloging of the burial offerings from INAH's "Proyecto Teotihuacan" excavations of 1960-1964 was done in 1978 at the Museum of Anthropology with the invaluable assistance of Noemí Castillo Tejero and Rosa Brambila, curators of the Teotihuacan collections. My assistant, María Elena Ruiz, rendered valuable help throughout the year we spent sketching and measuring the pieces in the storerooms of the Museum. José de los Reyes Medina, the photographer for the Department of Archaeology of the Museo Nacional de Antropología, took the excellent photos of the Teotihuacan vessels.

I am greatly indebted to INAH archaeologist Juan Vidarte who excavated the La Ventilla B compound, not only for making available to me his reports with excellent photographs but the many conversations and ideas he shared with me. I have relied extensively on Laurette Séjourné's published volumes on the Teotihuacan ceramics and without them our information on Teotihuacan burials would be greatly deficient. I am grateful to J. Bennyhoff, a member of the Teotihuacan Mapping Project, whose excellent and very complete notes on the burials from the INAH excavations were so helpful. I wish to express my appreciation to Rene Millon for the excellent experience of participating in the Teotihuacan Mapping Project. In the mid-sixties John Paddock and I excavated at the Oaxaca Barrio, Teotihuacan, an excavation sponsored by University of the Americas. I express my gratitude to John Paddock for introducing me to Oaxacan archaeology. The extensive excavations at Tlajinga 33, Teotihuacan by Penn State archaeologists William Sanders, Rebecca Storey and Randolph Widmer yielded new information on the burial customs of the Teotihuacanos and I thank them for allowing me to work with this valuable collection. Also, I thank Nicole Spitalier, my assistant at the Instituto de Investigaciones for her assistance in helping me inventory this large collection.

The next Project to yield a substantial body of data on Teotihuacan burials was the Merchants' Barrio Project. Among the many participants who worked in the field and laboratory with me, I gratefully acknowledge the assistance of Consuelo Quintana, Erendira Fajardo and Eduardo Gamboa.

Ruben Cabrera, director of the recent excavations of the Proyecto Arqueológico Teotihuacan 80-82 at the Ciudadela along with Saburo Sugiyama, a member of the INAH team, are responsible for the spectacular finds at the Ciudadela and I thank them for providing me with published and unpublished data on the burial finds.

Extremely important to this study have been the contributions of physical anthropologists Carlos Serrano and Zaid Lagunas for their studies on the skeletal material at La Ventilla B. We have been most fortunate in having Michael Spence to do the studies on the skeletal material from the Oaxaca Barrio excavations carried out by University of the Americas and the Teotihuacan Mapping Project. In addition we have benefited from his excellent studies on the human skeletal material of the Tetitla, Zacuala and Yayahuala compounds.

I also wish to extend my sincerest appreciation to Fernando Botas and Antonino Guzmán for their unstinting help in making up the illustrations for this volume.

Finally, Renee Yoder, Don Thieme, and Bridget Hodder Stuart at Vanderbilt University lent their time and expertise with computers to the editors of this volume and their aid is much appreciated. 



\section{THE TEOTIHUACAN BURIALS AND OFFERINGS}

\section{INTRODUCTION:}

A wealth of information on Teotihuacan burials has been collected in recent years. The present work attempts to bring together older published sources and more recent material, much of which is presented here for the first time. The major source of data for the burial inventories is the collections from Teotihuacan now located in the Museo Nacional de Antropología in Mexico City. Included in these collections are the burial offerings from the apartment compounds of La Ventilla A and B, Tetitla, Zacuala Patios and Zacuala Palace, and Yayahuala.

I began to assemble data for the inventory in 1978, while I was working on the Teotihuacan ceramic chronology (Rattray 1978, 1981). The study of whole vessels from burials added indispensable new information about form and size range of the pottery vessels, data that the fragmentary sherds from Teotihuacan surface collections had not provided. Comparisons of groupings of vessels from burial offerings and the ceramic associations found in the stratigraphic units substantially aided my revision of the chronology.

The initial inventory of the Teotihuacan burials done in 1978 has been updated in accordance with more recent work on the Teotihuacan ceramic chronology (Rattray 1981, 1986). This has resulted in the rephasing of certain burials. Furthermore, the inventory has been expanded to include new material from the Merchants' Barrio (Rattray 1984, 1985, 1987a \& b, 1991), the Oaxaca Barrio (Rattray 1979, 1987a; Spence 1989), the Proyecto Arqueológico Teotihuacan (Cabrera et al. 1982, Jarquín and Martínez 1982; Sugiyama 1986, 1989) and from the Tlajinga 33 compound (Sanders, Storey and Widmer 1982; Storey 1985, 1987; Widmer 1987a).

This is the first publication of complete inventories of the burials and offerings from the apartment compounds (Tetitla, Zacuala, Yayahuala and La Ventilla) and from the Tlajinga 33 compound, the Merchants' Barrio, and the Oaxaca Barrio. I classified the Tlajinga 33 burial offerings in the archaeological materials laboratory at the Instituto de Investigaciones Antropológicas of the Universidad Autónoma de México. Randolph Widmer and Rebecca Storey conducted the excavations at Tlajinga 33, and we worked together on the inventories and classification of the ceramic vessels using the revised Teotihuacan ceramic chronology (Rattray 1981). This provided Widmer and Storey with the chronological data required to interpret the different building stages at Tlajinga 33, as well as furnishing me with much of the information on burial customs upon which the present study is based. Widmer and Storey assigned burials without offerings to their respective stratigraphic positions in the structure (Sanders, Storey and Widmer 1982).

The original purpose of the inventory was to assemble as much data as possible on the location of skeletal remains and their associated offerings, and to chronologically order them based on the available stratigraphic data from excavations. When such data were lacking the burials were phased according to stylistic characteristics of the ceramics. With this accomplished, it soon became obvious that there were some regularities and patterns discernable in the mortuary customs of the ancient Teotihuacanos that reflected possible ethnic affiliations, wealth, social status, and religious beliefs.

Distinctive patterns having chronological significance emerged in the course of these studies:

1) A Terminal Formative pattern of sacrificial burials in pyramids and the customary burials in temple-like structures associated with residences. 
2) An Early Classic pattern, conforming to the typical burials of Teotihuacan apartment compounds, and non-conforming burials that were made by foreigners living in Teotihuacan in the different ethnic barrios.

3) A Late Classic pattern that continues many of the burial customs of the preceding period but with an increase in number of individuals buried and in the wealth displayed in the burial ceremonies at the apartment compounds of Tetitla, Zacuala, Xolalpan, and La Ventilla B.

The Merchants' Barrio and Oaxaca Barrio burials provide important comparative information for the study of ethnic groups residing in Teotihuacan from the beginnings of the Terminal Formative through the Late Classic Period. In three seasons nearly 3000 square meters were excavated at the Merchants' Barrio (Rattray 1984, 1987). The skeletal remains recovered were studied by physical anthropologist Magalí Civera (1983, 1989) at the Instituto de Investigaciones Antropológicas, UNAM, and relevant data are presented here. Also considered here are the burials and offerings from various earlier excavations at Teotihuacan, as well as those recovered more recently by the Proyecto Arqueológico Teotihacan (Linné 1934, 1942; Armillas 1950; Millon and Bennyhoff 196l; Cook de Leonard 1957 a, b, c; Noguera 1955; Muller 1978; Cabrera et al. 1982; González y Fuentes 1982; González y Salas 1990; Sugiyama 1986, 1989).

Information on type of interment (whether primary or secondary), location of burials (under house floors, in shrines or platforms, in specially constructed tombs), and physical characteristics such as age and sex are provided along with inventories of ceramic vessels and other offerings, such as shell, pigment, jade, and obsidian. Radiocarbon dates of organic materials directly associated with the burials are reported when available. The inventories of the burials and offerings are organized by phases, starting with the earliest at Teotihuacan, the Tzacualli phase, and continuing through to the final phase, the Metepec. The ceramic complexes have the same names as the phases and are as follows:

PHASE NAME
Metepec
Late Xolalpan
Early Xolalpan
Late Tlamimilolpa
Early Tlamimilolpa
Miccaotli
Late Tzacualli
Early Tzacualli
Patlachique

DATE
650-750 A.D.
550-650 A.D.
400-550 A.D.
300-400 A.D.
200-300 A.D.
150-200 A.D.
50-150 A.D.
$0-50$ A.D.
$150-0$ B.C.

PERIOD

Late Classic

Late Classic

Early Classic

Early Classic

Early Classic

Terminal Formative

Terminal Formative

Terminal Formative

Terminal Formative

\section{EARLIER STUDIES:}

The systematic study of Teotihuacan burials is relatively new. As recently as 1981 , researchers still had the erroneous idea that the deceased "were usually carefully wrapped and then cremated" (Weaver 1981: 203). Extensive excavations made in the administrative-ceremonial center of the city had failed to yield skeletal material. In his summary of the first season's work of the Proyecto Teotihuacan in the 1960's, Bernal (1963) wrote:

We do not have in the ceremonial zone of Teotihuacan a single burial, which demonstrates clearly that it was not customary to bury the deceased here, exactly the opposite of what we found in Monte Albán.

Even the extensive excavations in the residential apartment compounds of Tetitla, Zacuala Palace and Patios, and Yayahuala failed to produce large numbers of interments (Séjourné 1959, 1966 a, c). This seems most unusual, considering that these localities were inhabited for several centuries and the fact that each compound could have housed more than 100 individuals. 


$\ddot{-}$

acendel a do miter conse

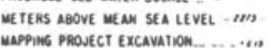

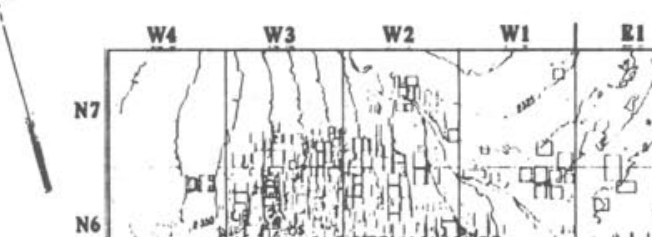

s2

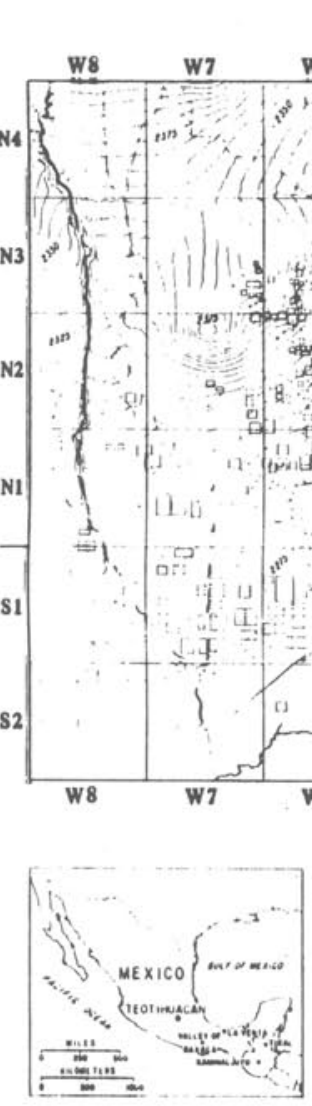

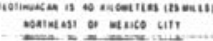

\section{TEOTIHUACAN} CENTRAL PLATEAU OF MEXICO ARCHAEOLOOGICAL AND TOPOGRAPHIC MAP (n)

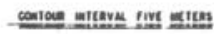

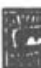

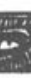

\section{N5 N6

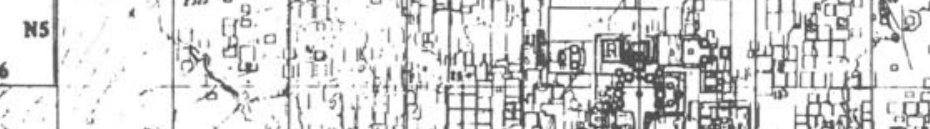
等

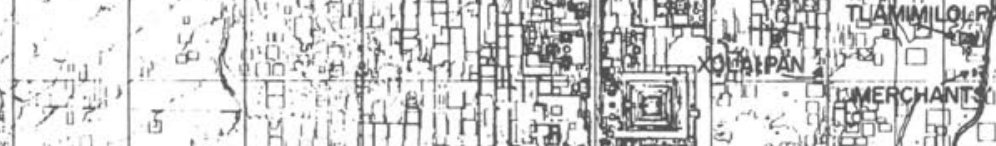

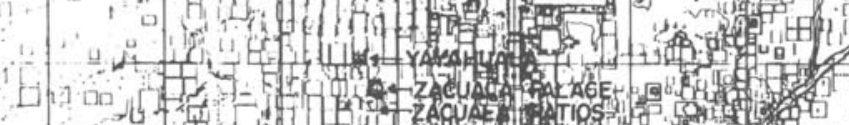

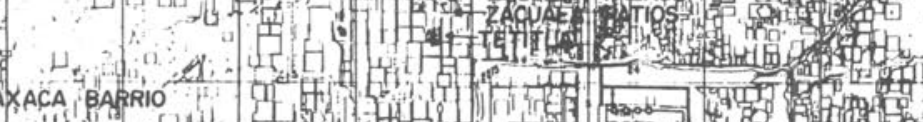

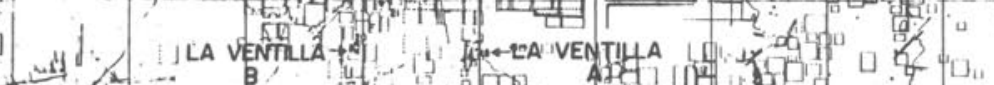

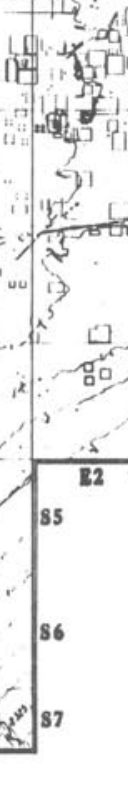

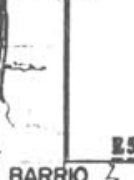

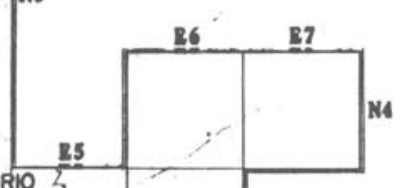

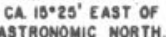

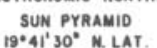
$19^{\circ} 41^{\circ} 30^{\circ}$ N. LAT. LAT.
$96^{\circ} 50^{\circ} 30^{\circ}$ W. LONG.

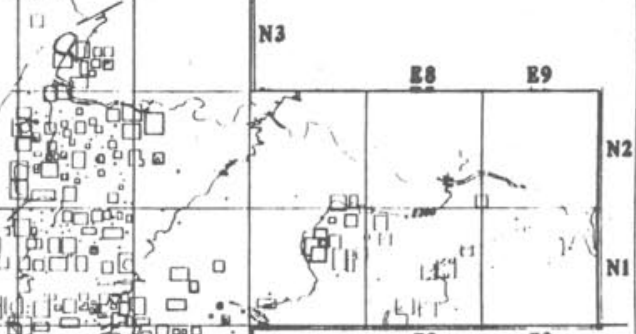

Fig. I

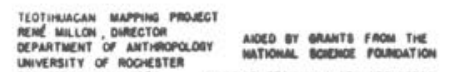

KEY TO INSET MAP

cuoudetis

Teume of outraccourt

sect or me oevo

ceat comomon.

paras of The roon

outzalpapalot palace.

crowip s'

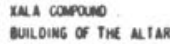

TEuplE of Acencu tues

wrthodocical amiens wares.

praze of $T$.

exporations of ins -

puace of the sum

mitio of tie rove sumct trunts

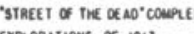

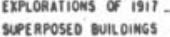

Explonations of 1900

zacuma parios

w1 I N B B T A P $\quad 1$

no m $x^{2}$ o 1n. cocarion of user un 1 ,

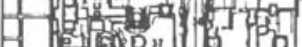

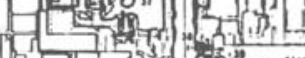
7 . 3 s. f $=-1 .=-1$

м 7 ant दिic

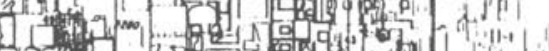

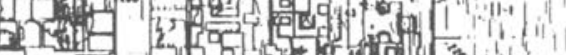

Figure 1: Map of Teotihuacan showing locations of the compounds, barrios, and sites discussed in the study. Base map from Millon, Drewitt, and Cowgill 1973

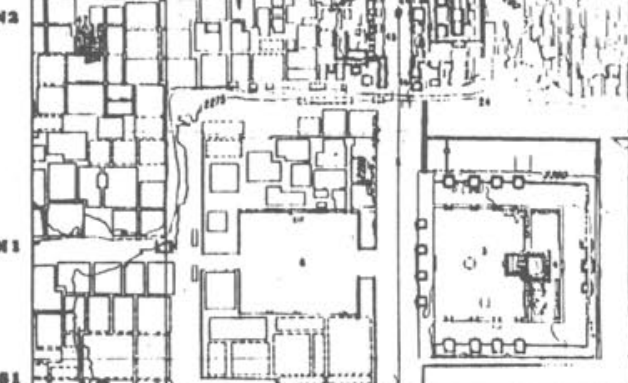


The lack of information on burials has persisted until recently. The primary reason for this is that excavators had not consistently reported or published their findings. Sometimes excavations were reported only in official reports (informes) for the Instituto Nacional de Antropología e Historia. Some areas, however, such as those excavated in 1980-82 by INAH along the Avenue of the Dead, have truly lacked burials. The excavation of 9800 square meters on the west side of the Avenue in the Calle de los Muertos complex (CMC) revealed spacious plazas, temple platforms, habitations, adoratorios, storage rooms, collonaded porches, streets and various other constructions, but no burials (Morelos 1985). The Northwest Complex, on the other hand, yielded an area of burials which included an interment of an important person with a rich offering (Sánchez 1982).

Data compiled in the present study (see fig. l) are derived from numerous excavations conducted by Mexican and foreign archaeologists, the majority dating from the 1960's. The inventoried burial lots are from the apartment compounds of Tetitla, Zacuala, Yayahuala and La Ventilla A and B (See fig. 1; Séjourné 1959, 1963, 1966 a, 1966 b; Rattray 1978; Rattray and Ruiz 1980), from the Oaxaca Barrio excavations (Rattray 1979, 1986, 1987 a; Spence 1976, 1989, 1990), the recent excavations at the Merchants' Barrio (Rattray $1984,1987 \mathrm{~b}$ ), and the material from the burial offerings recovered from the Tlajinga 33 compound (Sanders, Storey and Widmer 1982; Storey 1987, Storey and Widmer 1989; Rattray 1983). Published works, such as those on the compounds of Tlamimilolpa and Xolalpan (Linné 1934, 1942), on the Ostoyahualco burials (Cook de Leonard 1957 b) and caches (Millon, Drewitt and Bennyhoff 1965) and on a single burial from near the Ciudadela (Noguera 1955), have been utilized. To date, only brief summaries have appeared on the 100 or more burials recovered during the 1980-1982 Proyecto Arqueológico Teotihuacan (Cabrera, Rodríguez and Morelos 1982; González and Salas 1990). Information on Teotihuacan burials is now extensive. Since preparation of the present study, new excavations in Teotihuacan have revealed scores of new burials, such as those from a Xolalpan phase compound in Ostoyahualco where twenty burials were recovered (Manzanilla 1991, personal communication) and from the continued excavations in the Ciudadela at the Temple of Quetzalcoatl (Cabrera et al. 1990; Sugiyama 1986, 1989).

Among the earliest known Teotihuacan burials are the Patlachique and Tzacualli phase burials from Tlachinolpan ${ }^{1}$ (Blucher 1971) and the child interments (probably sacrificial) at the corners of the Pyramid of the Sun (Batres 1906: 22, illustration 40 following page 30 of text), apparently without goods. Burials of similar age and type have also been found at the Teotihuacan related sites of Pueblo Perdido, near Azcapotzalco (Rattray 1968), and at Cuanalan (Manzanilla 1985).

\section{COMMENTARY ON THE TEOTIHUACAN BURIALS:}

The purpose of the present study is to assemble the many data derived from the burial reports and the excavations and to organize them by chronological periods and phases. Grouping phases into larger blocks of time helps to focus more clearly on certain traits that remain fairly stable and facilitates the detection of patterns. This leads to a better understanding of the mortuary-offertory customs of the Teotihuacanos. Dating of the individual burials is not yet precise enough for an analysis of blocks of time equivalent to the Teotihuacan phases.

Data are sparse for the Terminal Formative-Early Classic Periods (Tzacualli-Early Tlamimilolpa phases) at Teotihuacan. The earliest known burials are those of children (probably sacrificial) made in the four corners of the Pyramid of the Sun (fig. 2a; Batres 1906: 22, fig.40, following page 30). It is also possible that a large tomb may be concealed within the Pyramid of the Sun near the center (Millon, Drewitt and Bennyhoff 1965: 35). Clear distinctions exist between burials associated with the large monumental structures--the Pyramid of the Sun and the Temple of Quetzalcoatl--and those from structures that are primarily habitational, such as La Ventilla A and B and Tlajinga 33.

\section{The Terminal Formative Pattern: Pyramid-Temple Burials:}

Highly characteristic of Teotihuacan are the three-temple complexes, some twenty of them 


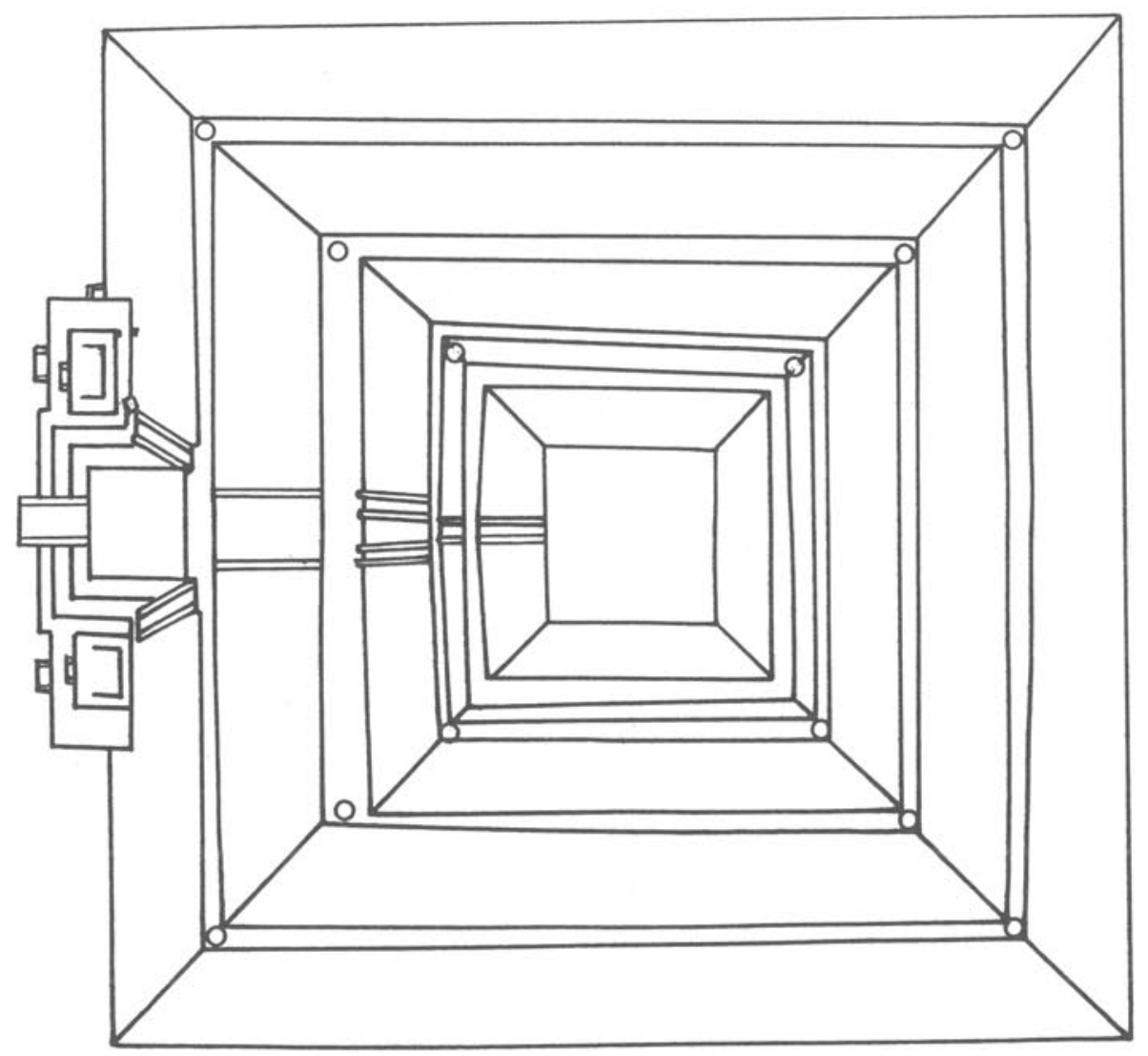

\section{a. Pyramid of the Sun. O Child burials (Batres 1906)}
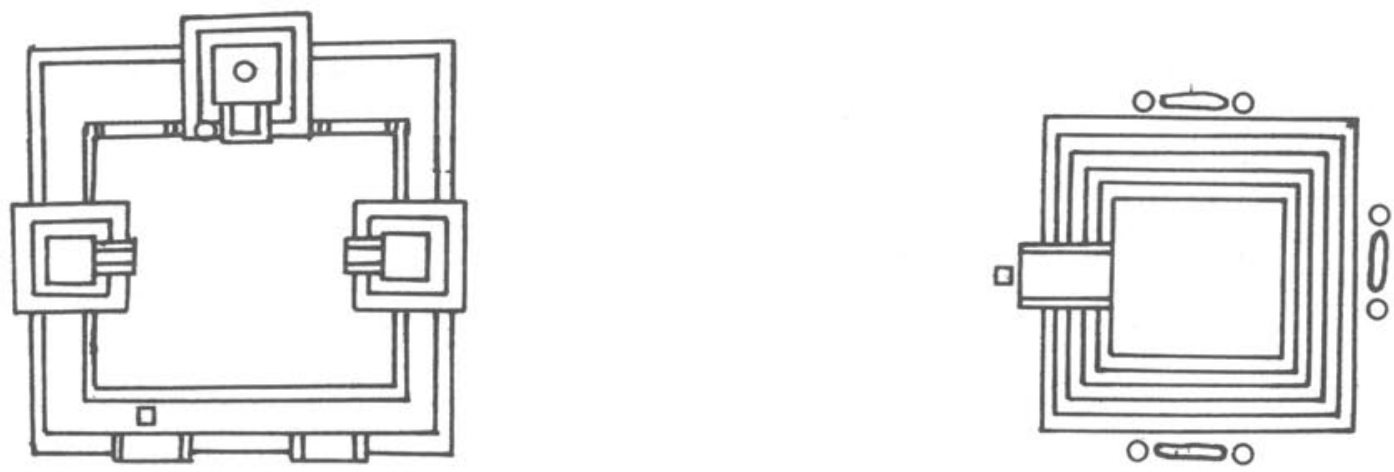

\section{b. PLAZA One}

\section{Ostoyahualco}

3 - Temple Complex

O Burials $1-12$ a Cache

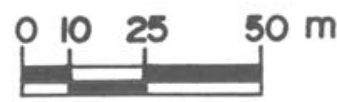

Figure 2: Plans of Terminal Formative Pyramids and Temples: a. Pyramid of the Sun, the locations of child burials indicated; b. 3-Temple Complex at Plaza 1, Ostoyahualco, showing locations of Burials 1-12 and Caches; $\mathrm{c}$. The Temple of Quetzalcoatl with Burials and Caches indicated. Buildings are shown in final stage (Xolapan-Metepec Phases); The Terminal Formative constructions are buried within. Plans based on Millon, Drewitt, and Cowgill 1973. 
attributed to the Tzacualli phase. Ostoyahualco, a site within the district known as the "Old City" of Teotihuacan, is one of the earliest of these complexes to be excavated (figs. 1 and 2). Cook de Leonard (1971: 191) excavated there in 1957 by means of a tunnel into the central mound, and unearthed twelve burials. These were adults in flexed positions, many associated with "Tlaloc floreros" (Plate II; fig. 3 ). ${ }^{2}$ They were wrapped mummy-style in cotton cloth or ixtle and in one instance, placed on the steps of the substructure. These do not appear to have been sacrificial victims, but we do not rule out the possibility. Cook de Leonard (1971: 191, fig. 10a) concluded that "the burials in Pyramid B of Plaza 1, Ostoyohualco" belonged to newly arrived peoples, the architects, who placed their dead within the sacred pyramidal structure with "Tlaloc floreros". She postulates that the caches discovered in the South Platform, on the other hand, belong to workers or peons, peoples who "did not conform to the trends of the new upper class and emigrated." It is now known, however, that the Mound B "Tlaloc floreros" and the flexed burials within the pyramid are typical of Teotihuacan. They date to the Early Tzacualli phase, whereas the Tzacualli phase "resist wares" from the deep caches could have been a new introduction, perhaps from the Gulf Coast region. ${ }^{3}$ Although Cook de Leonard (1971) placed these burials in Teotihuacan II (Miccaotli phase), I have reevaluated the evidence and corrected the dating to Teotihuacan I (Early Tzacualli phase). ${ }^{4}$ The Ostoyahualco burials fit into the pattern we have mentioned of burials associated with large ceremonial structures. Undoubtedly, many more three-temple complexes along the Avenue of the Dead contain burials as well.

Recently discovered offerings from the cave and tunnel system under the Pyramid of the Sun also suggest Gulf Coast contacts in Tzacualli times (fig. 2a)(Rattray 1986). Two basalt disks bearing "Tajín scrolls" and depicting Gulf Coast individuals could indicate the presence of such foreigners in Teotihuacan. According to Doris Heyden (1975: 131, figs. 2, 3):

In these chambers numerous vessels of crude manufacture were found, together with two thin basalt disks beautifully engraved with anthropomorphic figures, one dressed in a jaguar costume, another as a bird (figs. 2,3). These disks have Gulf Coast stylistic influence and show evidence of having been inlaid with other material, which is missing. Both the clay vessels and disks were intentionally broken when placed in the chambers. The disks appear to have been mirror backs.

The "crude" jar or olla described and illustrated by Heyden (1975: fig. 2) is of the same type as the ones I classified from the ceramic collections recovered in Millon's 1978 excavations in the tunnel system. Besides the wedge rim jars in matte finish, sherds of cazuelas, floreros, fluted jars, low walled plates, bowls and a tumbler were recovered (Rattray 1981). Millon (1981: 234) suggests that "everything done to the cave and in the cave proclaims ritual", noting that the three most common types of vessels used in cave ritual, the plate or low-walled dish, the jar and the florero do not occur commonly together in other contexts and "seem peculiar to cave ritual".

Gamio (1922) and others carried out extensive excavations at the Temple of Quetzalcoatl from 1917 to the early 1920's. In the process of excavating the "Templo Viejo", the earliest of the two constructions, Dozal (1925: 218) discovered at the four corners, human skeletons buried with offerings, almost certainly sacrificial victims (Sugiyama 1986, fig. 30). Important dedicatory caches included one at the base of the Temple of Quetzalcoatl (fig. 2c) and discoveries made in the upper part of the Temple. These have been described by Marquina (see Gamio 1922: 157-158) and Rubín de la Borbolla (1947). The stairway caches (associated with isolated teeth only) are the next earliest known after the Ostoyahualco findings. A few dateable ceramic artifacts were included; the moldmade figurines (Rubín de la Borbolla 1947: 63, fig. 13a, and possibly $\mathrm{d}$ and $\mathrm{f}$ ) included in the "dedicatory offering" appear to have been placed by the third or fourth centuries A.D. (the Early to Late Tlamimilolpa phases) and may postdate the building of the Temple of Quetzalcoatl. 

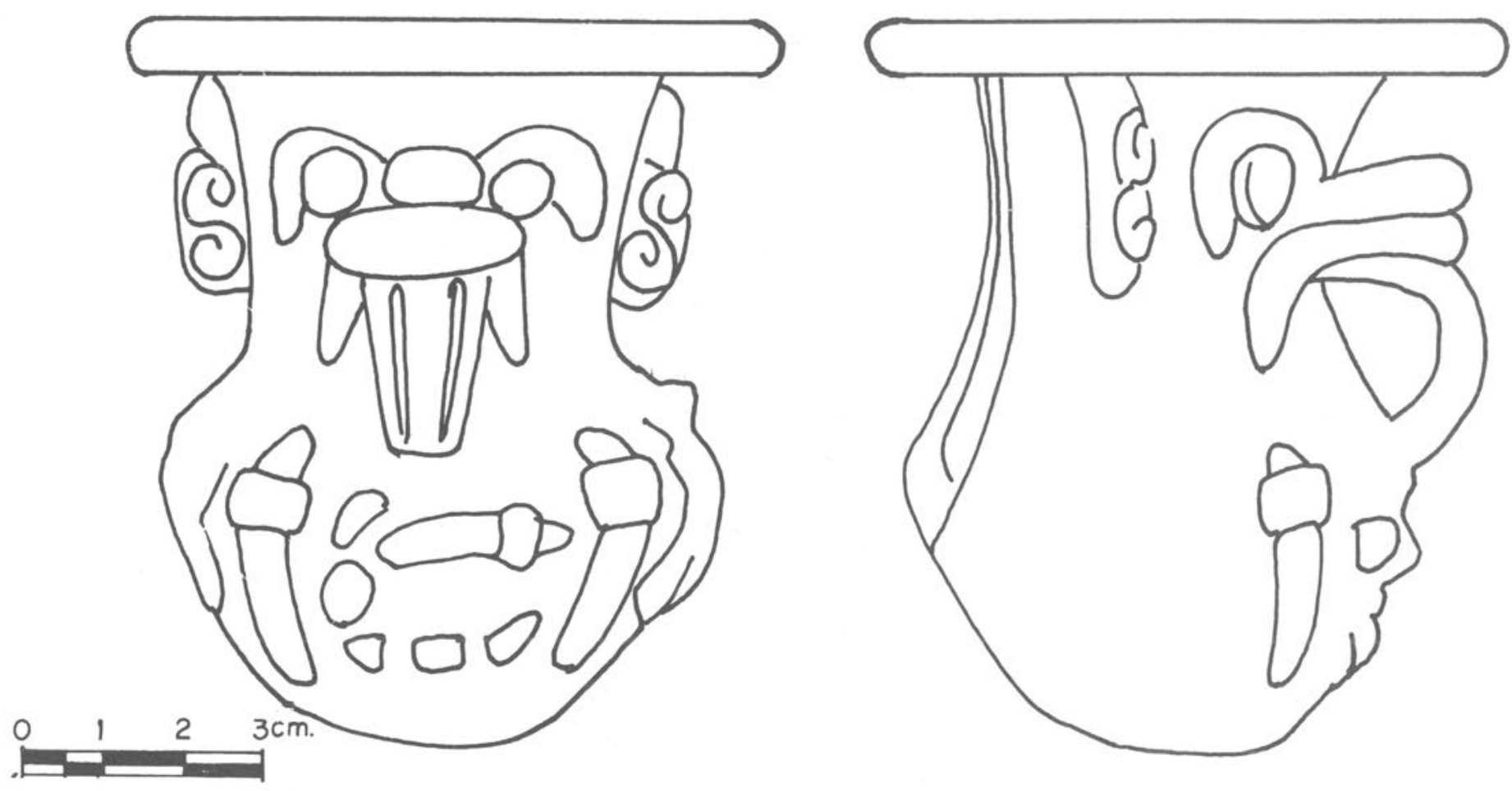

Figure 3: "Tlaloc Floreros" from Ostoyahualco, Teotihuacan.

TEMPLE OF QUETZALCOATL

South Side

Plan of Burial 190

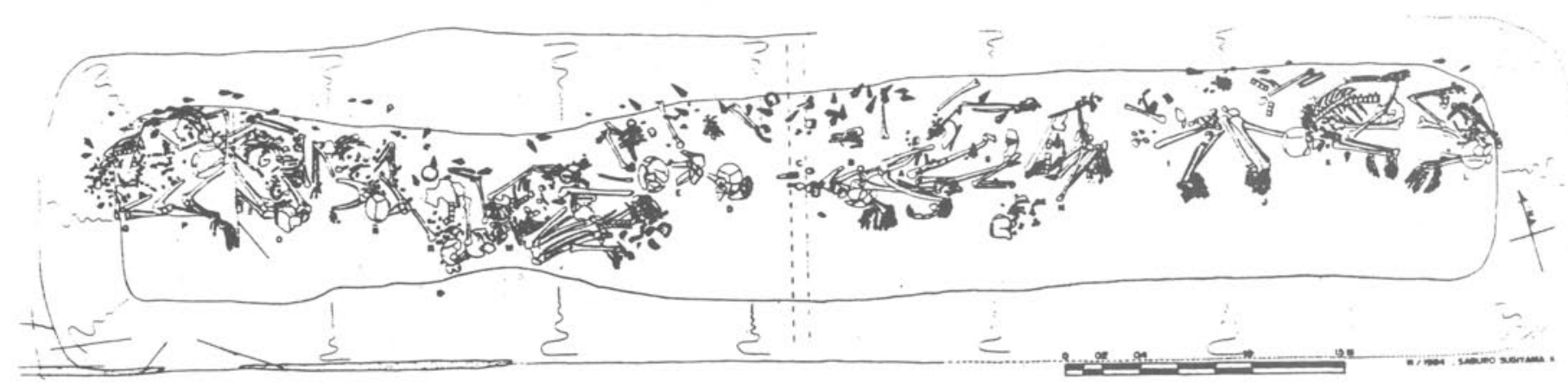

Figure 4: Plan of Burial 190, South Side, Temple of Quetzalcoatl. Reproduced from article by Sugiyama, 1989, Figure 5 . Courtesy of American Antiquity. 


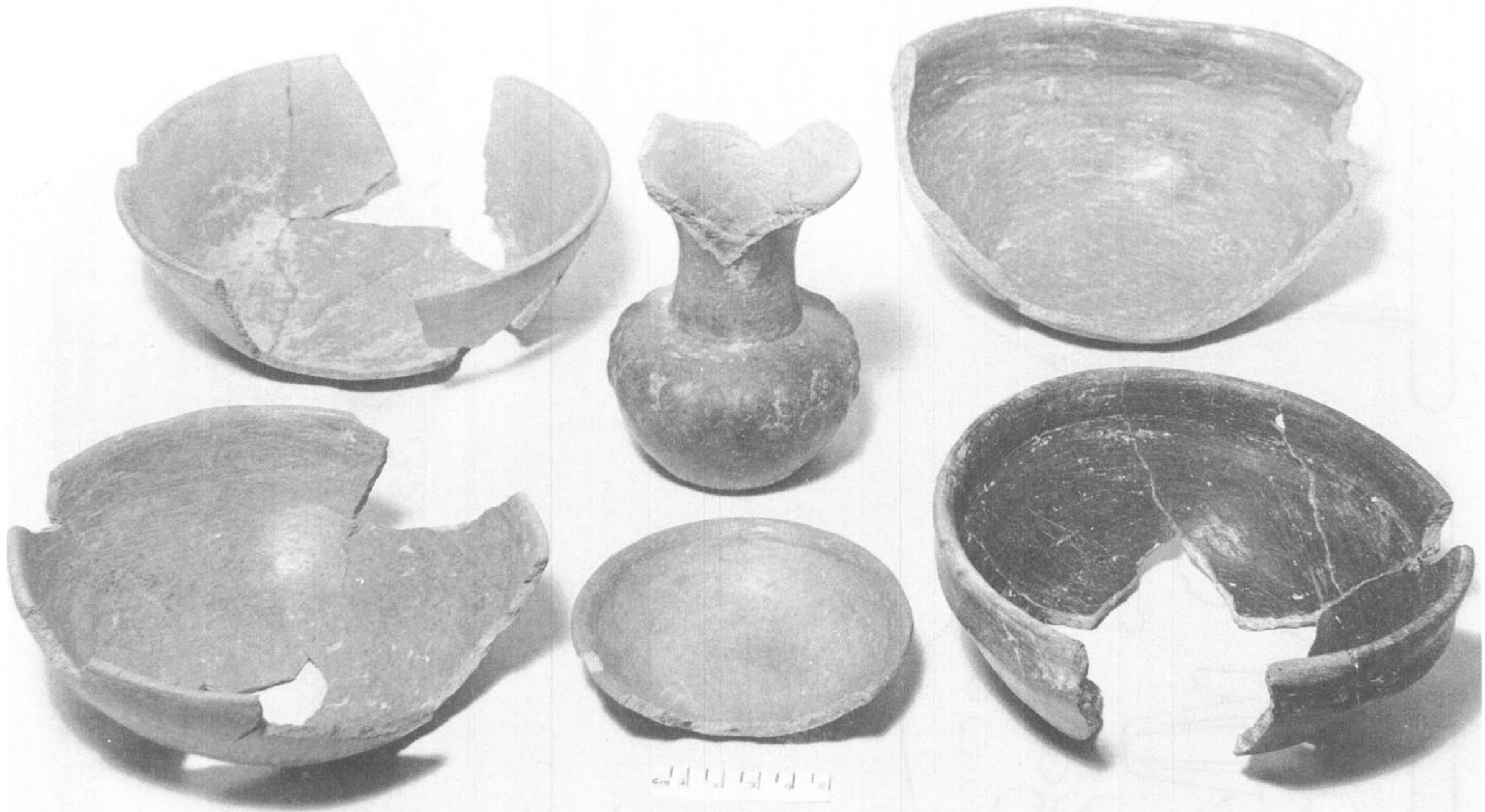

Plate I: Early Tzacualli Phase Burial Offering from Pueblo Perdido, San Bartolo Naucalpan, State of Mexico (near Azcapotzalco). a. Hard Orange bowl (foreign of unknown origin); b. florero; c. Bi-Pinched Red-on-Orange bowl; d. Hemispherical bowl; e. Red-Rimmed miniature plate; f. Black, rim-shouldered bowl (reproduced from Rattray 1968). 
New data come from the recent Proyecto Arqueológico Teotihuacan excavations (Cabrera et al. 1982) and from subsequent excavations by Sugiyama $(1986,1989)$. Sugiyama discovered "a ritual grave complex dedicated to the Old Temple of Quetzalcoatl" in which there were eighteen individuals in an enormous burial pit found below the south facade near the center of the Temple (fig. 4). The appearance of a symmetrical pattern of the dedicatory caches led to the discovery of a corresponding multiple grave on the south side of the Temple (fig. 2c) (Jarquín and Martínez: personal communication, 1986; Sugiyama 1986: 7). Although rich in other goods (obsidian and shell artifacts), these sacrificial burials have few ceramic offerings and pose a problem for dating. The radiocarbon dates suggest the ceremonial sacrifices took place in Miccaotli and Early Tlamimilolpa times. ${ }^{5}$

A complete inventory of the material recovered from these burials has been published by Sugiyama (1989) that consisted mainly of Pacific Coast shells, gray obsidian projectile points, pyrite disks (the back waist ornaments, the tezcacuitlapilli worn by warriors) worked human maxillae and mandibles, and shell imitations thereof. Certain individuals were also associated with green stone ornaments, earplugs and nosepieces in the shape of butterflies. Interestingly, a male in Early Tlamimilolpa Burial 21 (Plate III), La Ventilla B compound (Rattray and Ruiz 1980; Sugiyama 1989) was accompanied by similar paraphernalia including three pyrite disks.

Recent extensive excavations carried out by Cabrera and Cowgill (Cabrera et al. 1990) clearly indicate the sacrificial nature of these human offerings. The individuals are mainly males, their hands are tied behind their backs, and they are dressed in military attire. Antecedents to burials associated with a major mound have been found at the site of the round pyramid of Cuicuilco A, where a dozen individuals were placed perpendicular to the circumference of the the outer platform (Noguera 1939: 210-221). Cummings also found similar burials

(Schavelson 1983: Photo 26). Very possibly these were related to sacrificial-ceremonial rites that were later introduced to the Teotihuacanos and survived into the Miccaotli-Early Tlamimilolpa phase as manifested in the mass sacrifices performed during the building and inauguration of the Temple of Quetzalcoatl (Cabrera et al. 1990). ${ }^{6}$ The dominant theme of burial practices in this period is their association with temples or large monumental structures, often associated with sacrificial rites.

Terminal Formative Burials in Residential Complexes:

Apparently, the terminal Formative populace at Teotihuacan lived in insubstantial housing, and consequently, few of their burials have survived. Antecedents occur at Cuanalan (Manzanilla 1985) and Tlachinolpan (Blucher 1971) where individuals were buried in pits under the floors of dwellings and in the patios. The Pueblo Perdido burial (Plate I) (Rattray 1968), contemporaneous with the Ostoyahualco burials, is similar in form and may have been a temple burial, but the original context is unclear. ${ }^{7}$ With the exception of the North and South Palaces at the Ciudadela (from which we have four burials), residential structures are little known prior to the Early Tlamimilolpa phase. Beginning with the Early Tlamimilolpa phase, good data on mortuary practices were collected from Tlajinga 33 (fig. 5a) (Widmer 1987a; Storey 1987) and from La Ventilla B (fig. 5b, c) (Vidarte 1964; Serrano and Lagunas 1975; Rattray and Ruiz 1980). At La Ventilla A (fig. 1) an Early Tlamimilolpa burial associated with a Ball Court Marker or stela was recovered from a patio containing a T-shaped altar (Aveleyra Arroyo de Anda 1963: 17-18, 1964: 26). Another such T-shaped altar was unearthed in Patio I at La Ventilla B, but no stela or burial was found (Vidarte 1964). A recently discovered ballcourt marker mounted on a small talud-tablero altar at Tikal is similar in style to the La Ventilla A and B examples. The Tikal marker has an inscription referring to its "planting" in the year 414 (Schele and Freidel 1990), a date that is 50 to 100 years later than the ceremonial burial of the La Ventilla stela.

La Ventilla B Compound:

The distribution of its burials strongly suggests that the La Ventilla B compound grew out of small patio groupings. These groupings, which were the major foci of Early Tlamimilolpa burials, are: "Patio 

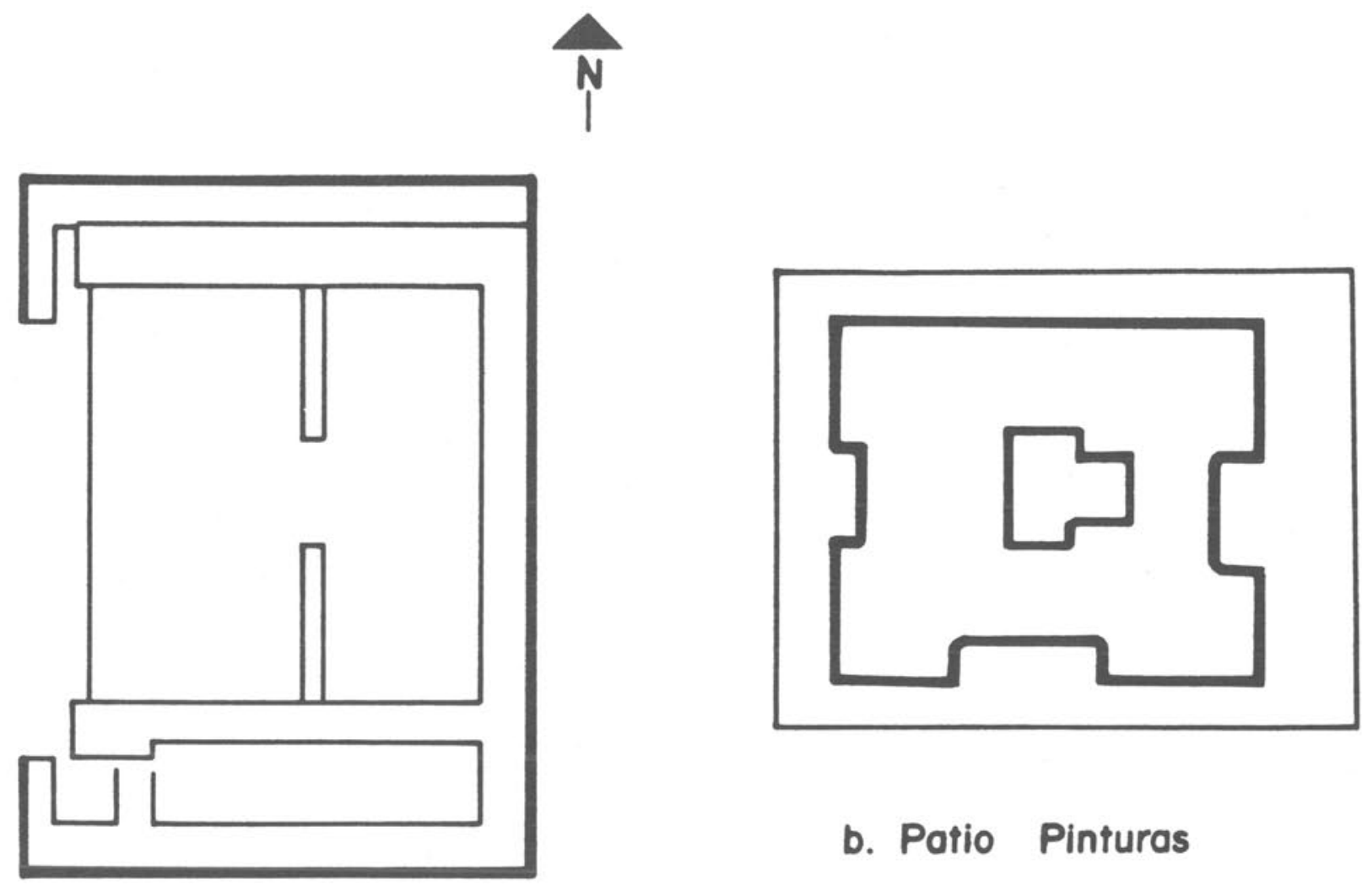

\section{b. Patio Pinturas}

a. Tlajinga 33
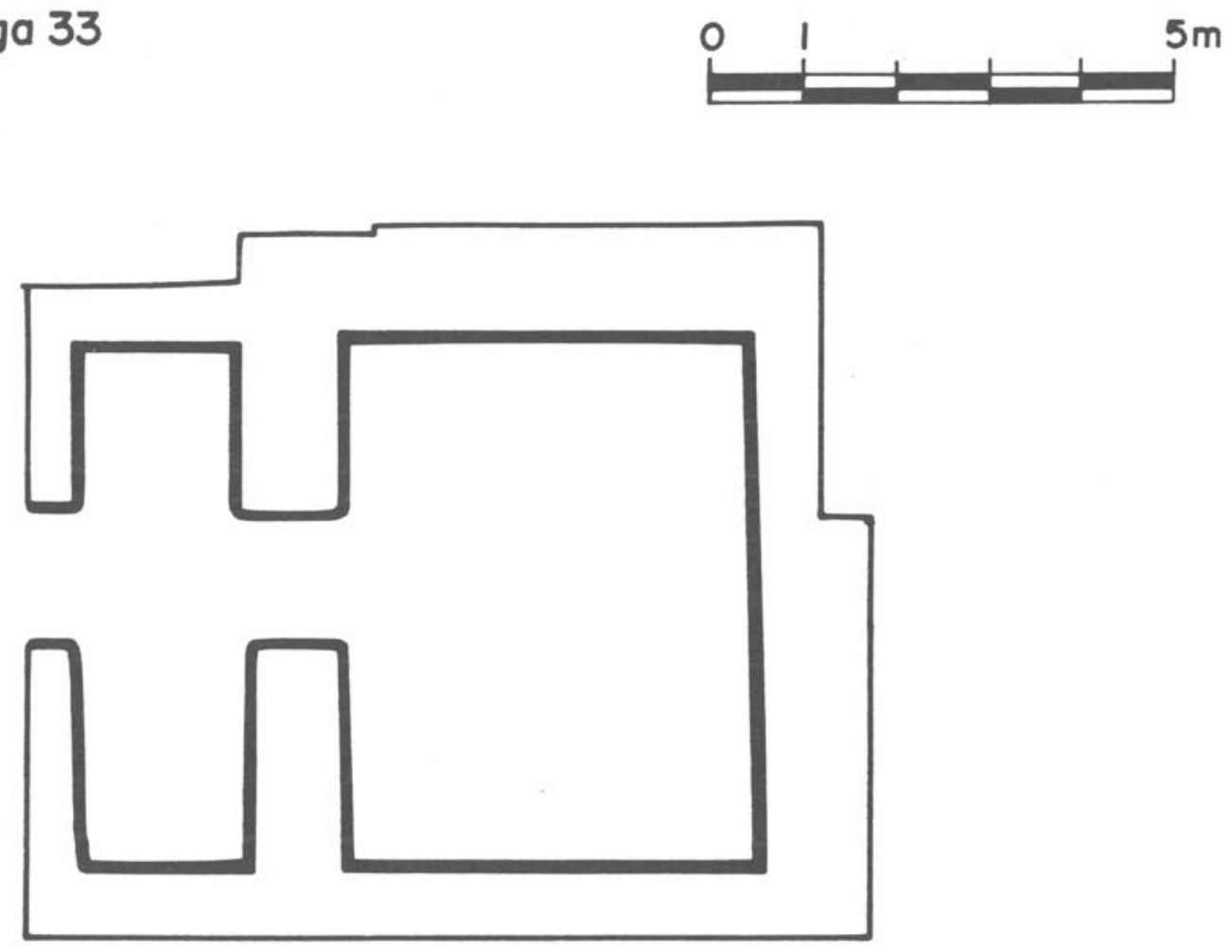

c. Patio 5 Group

Figure 5: Plans of Terminal Formative Patios and Temples at Residential Compounds. a. Early Tlamilolpa Phase Temple at Tlajinga 33; b. "Patio Pinturas", La Ventilla B, with T-shaped altar and stairs on east, west, and south that once led to temples; c. Patio 5 Group Temple at La Ventilla B. 


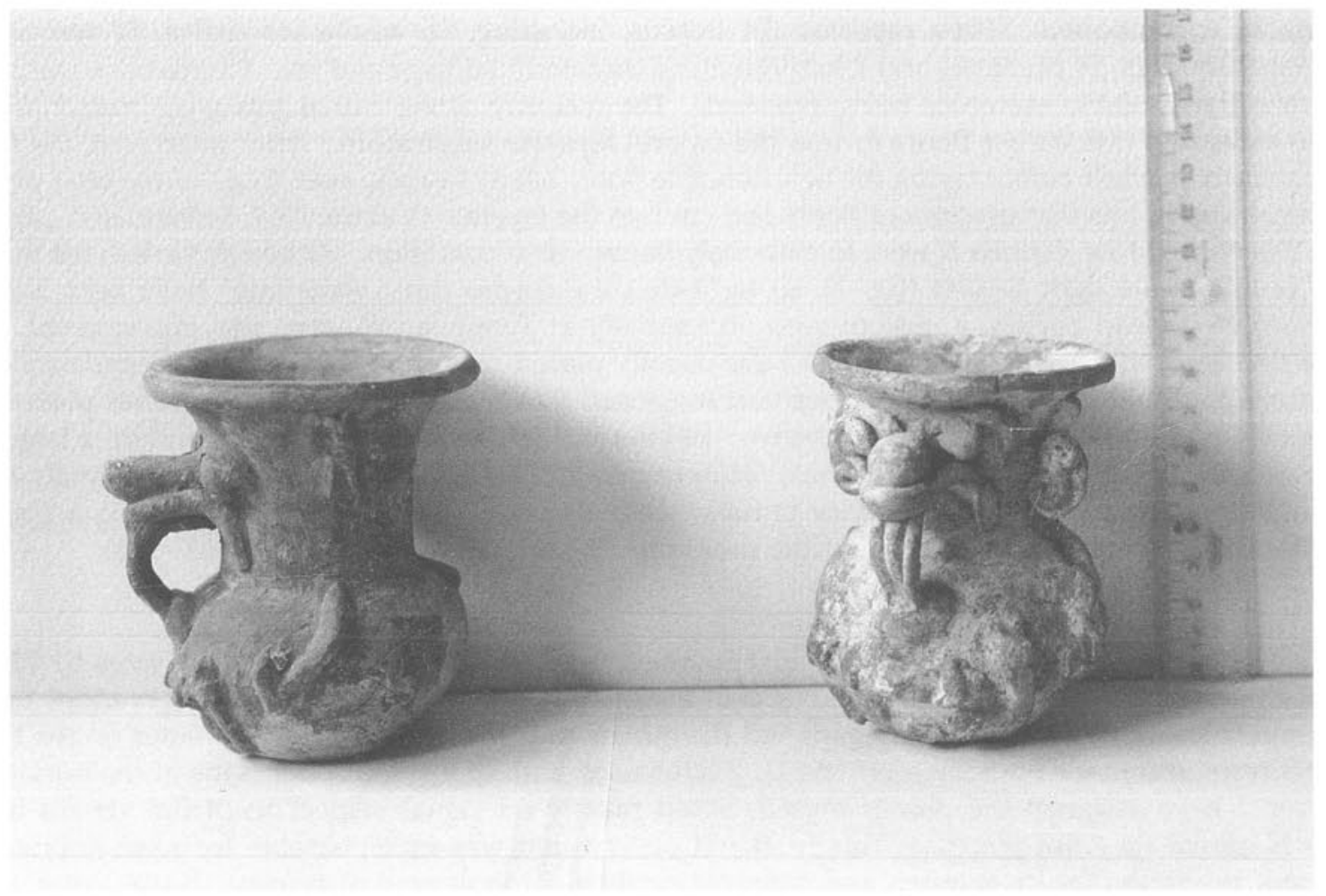

Plate II: Tlaloc floreros from Mound B, Ostoyahualco. a. side view of florero from Burial 1-2; b. front view of florero from Burial 6. Photo taken by E. Rattray for C. Cook de Leonard, 1987. 
Pinturas" (Altar Room II), with its adjoining plaza, and Altar Room I; Patio 5 to the south; and Adobe Room 3 on the east side of the later compound (fig. 6). These areas appear to have been public or ceremonial rather than habitational, the people buried in them probably having lived nearby in perishable structures. "Patio Pinturas", which has three stairways that probably led to three temples, is considered to be the earliest structure at La Ventilla B (Vidarte 1964). Patio 7 may have had a similar layout, suggesting that La Ventilla B may have been built around three-temple complexes. In this period much energy was expended on temple constructions rather than on elite or commoners' housing. House compounds do not become common until the Late Tlamimilolpa phase. A few early platforms like those on the Street of the Dead (Cabrera and Soruco 1982) may be the forerunners to compounds.

Serrano and Lagunas (1975) conducted osteological studies on human skeletal material from the La Ventilla B compound. They reported 174 burials, including 106 adults (43 males, 52 females), 8 juveniles, 24 infants, 34 prenatals and 2 individuals of undetermined age and sex. Cremations were rare, only three indisputable examples being reported. The majority of the burial pits were round or oval cavities excavated into earlier floors or into the natural tepetate substratum. After interment, the floors were carefully patched before laying the new concrete floor. Many burials, even those of the later phases, were deposited in pits that penetrated floors and cut into the tepetate (Vidarte 1964; Serrano and Lagunas 1975). The bones of La Ventilla B were in extremely deteriorated condition. Although varied, the normal burial position was tight flexure (fig. 7), so tight that the corpse must sometimes have been tied up mummy-style. Head burials, a custom seen occasionally at Teotihuacan, were also encountered. The vessels that accompanied the adult burials were usually placed about the bundle, with a tendency to be concentrated around the feet. Their disposition suggested that the artifacts were sometimes placed in a bag that disintegrated, spilling out the contents. Infants and fetuses often received burial on a large olla sherd, sometimes in altars. Primary burials far outnumbered secondary and incineration burials at the La Ventilla B compound. The secondary burials "were almost always the result of shifting a primary burial to make room for another body in the same pit" (Serrano and Lagunas 1975: 107-108).

The 174 burials that Vidarte excavated spanned the Early Tlamimilolpa (fig. 6, Plates III-VIII) to Metepec phases at La Ventilla B. At the time of excavation, Vidarte recorded his observations on the stratigraphic locations and tentatively assigned the burials to phases (Vidarte 1964). Notes on the burial contents were also made by Bennyhoff (1964). I have used both in my reconstructions of the burial lots. However, I have assigned the phases myself, based mainly on visual inspection of the vessels in the Museo Nacional de Antropología. This firsthand observation was indispensable for reassembling the burial lots, preparing the inventories, and determining their chronological placement. It was not possible for me to stratigraphically reconstruct the chronology of the burials at La Ventilla B. Burials have been seriated on the basis of the associated ceramic vessels. The burials subject to such relative dating at $\mathrm{La}$ Ventilla B are: 22 Early Tlamimilolpa burials; 19 Late Tlamimilolpa burials; 7 Early Xolalpan burials; 11 Late Xolalpan burials and 8 Metepec burials (see inventories in Appendix). Sixty-six individuals were interred without offerings and twenty-seven with undateable objects only or matte ware miniatures, which show little change from Tlamimilolpa to Metepec times.

Altar II in the "Patio Pinturas" contained five fetal burials (designated with numbers 152 to 156 , Serrano and Lagunas 1975: 143, Table 14) that were placed at the time of the building of Altar II, that is, in the Early Tlamimilolpa phase. Four of the five altars at the La Ventilla B contained infant burials, suggestive of a sacrificial custom (Vidarte 1964). The high infant mortality, amounting to $20 \%$ of the osseous material recovered, is interpreted by Serrano and Lagunas as having been caused by both biological and cultural factors. They believe that the presence of so many fetuses in the altars could indicate intentional acts of abortion performed at the time that the altars were constructed. Storey (1985: 531 , Table 5), on the other hand, attributes the $31.3 \%$ mortality rate among perinatals at Tlajinga 33 to poor nutrition and disease. 


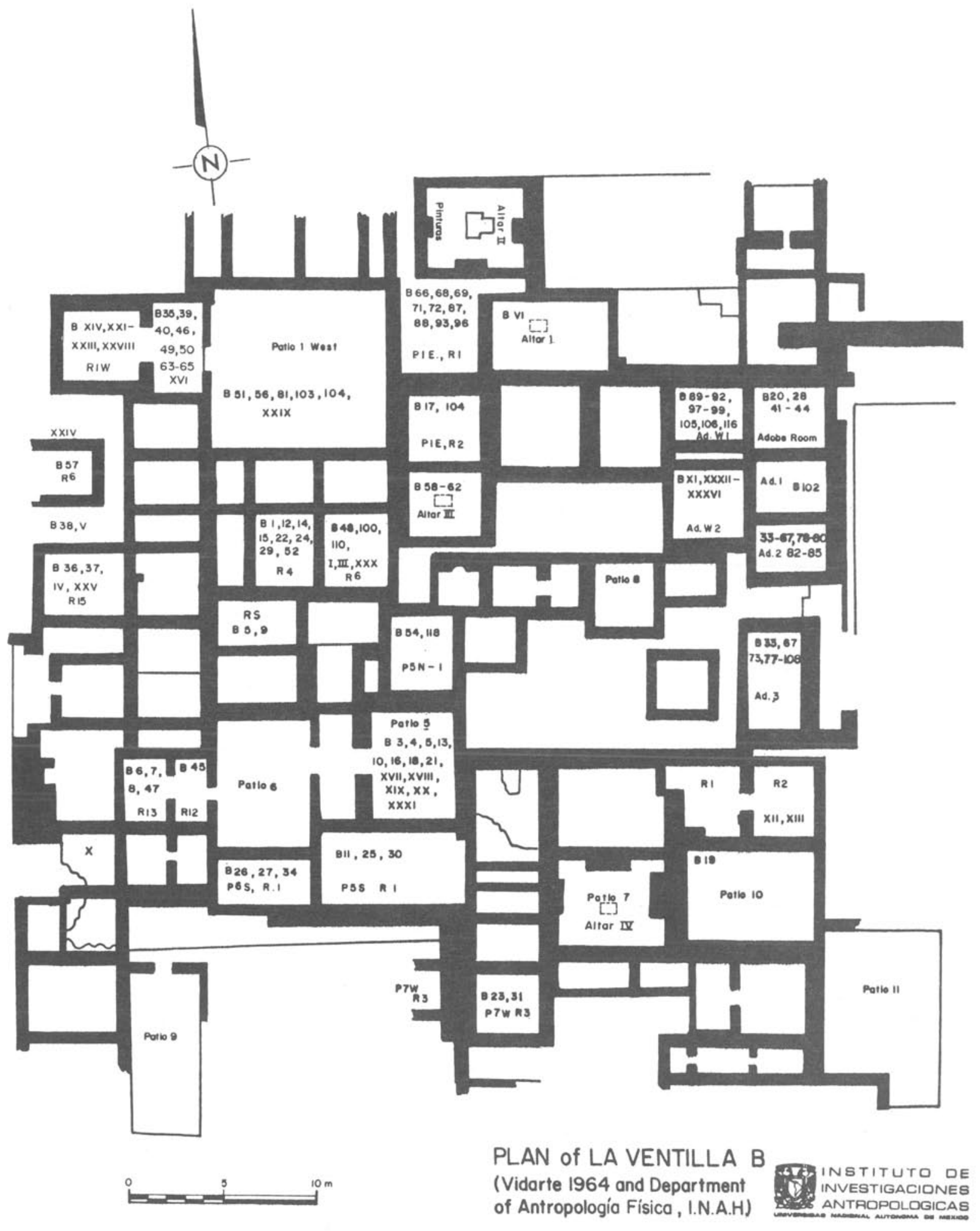

Figure 6: Plan of La Ventilla B Compound with Burial Locations indicated. Redrawn from Plan provided by Vidarte (1974). 

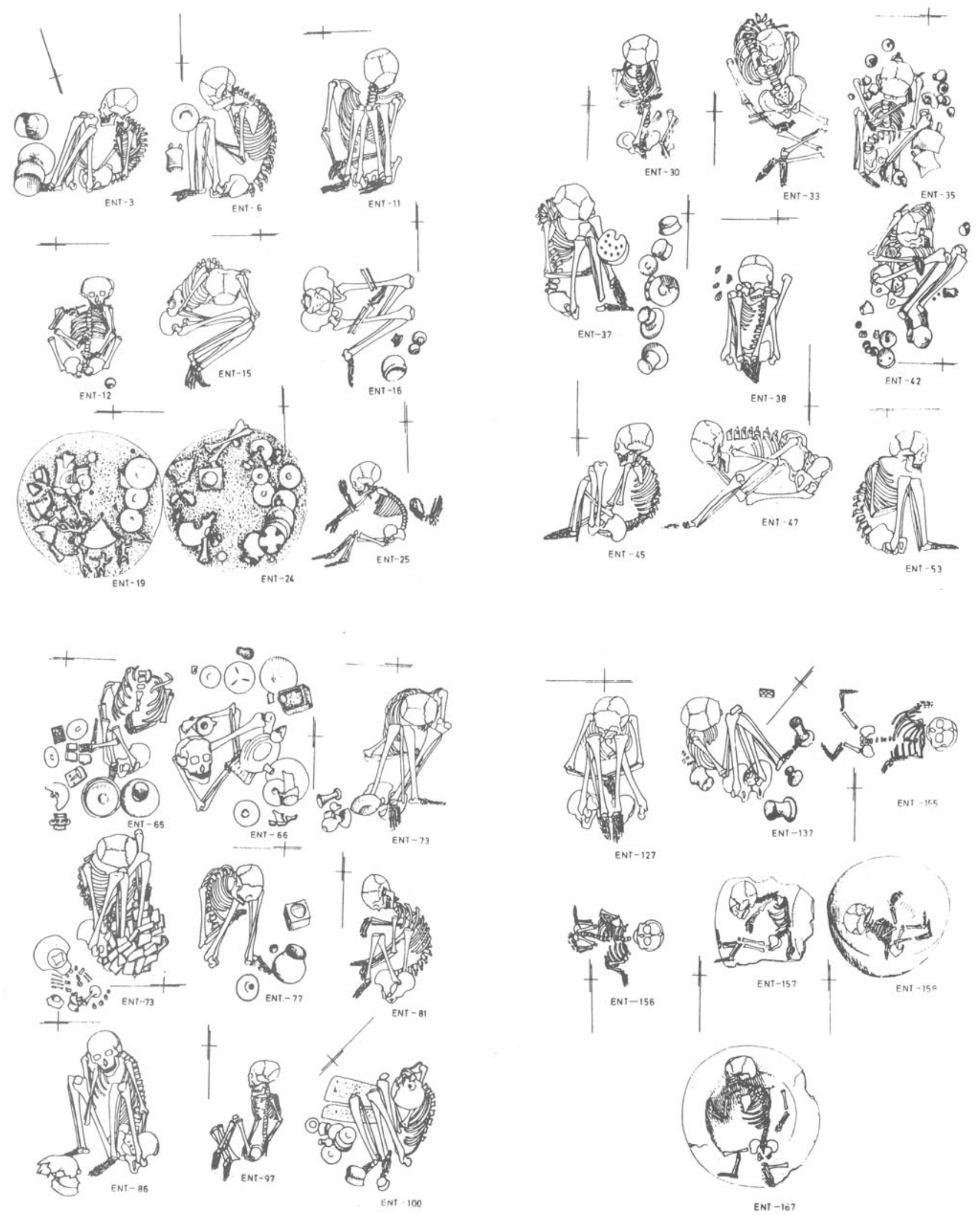

Figure 7: Positions of skeletons excavated at La Ventilla B by Vidarte (1974). From Serrano and Lagunas (1974, Figure 5). Courtesy C. Serrano and the Instituto Nacional de Antropología e Historia. 


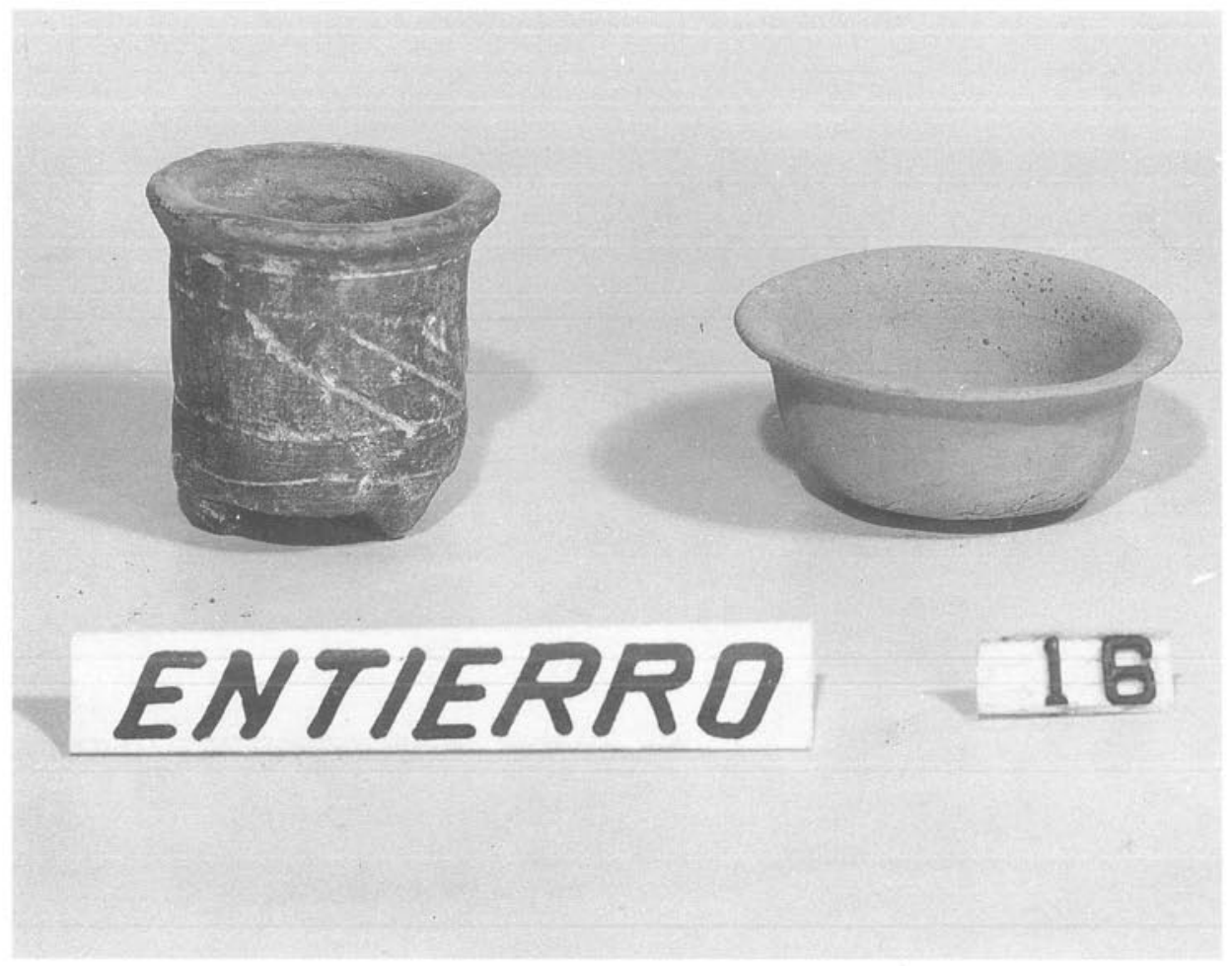

Plate III: Offering from Early Tlamimilolpa Phase Burial 21, La Ventilla B compound. The rich offering contained jade earspools, a jadeite nosepiece in the form of a butterfly, pyrite disks, jadeite beads and other goods listed in the inventory. Photo by Vidarte. 


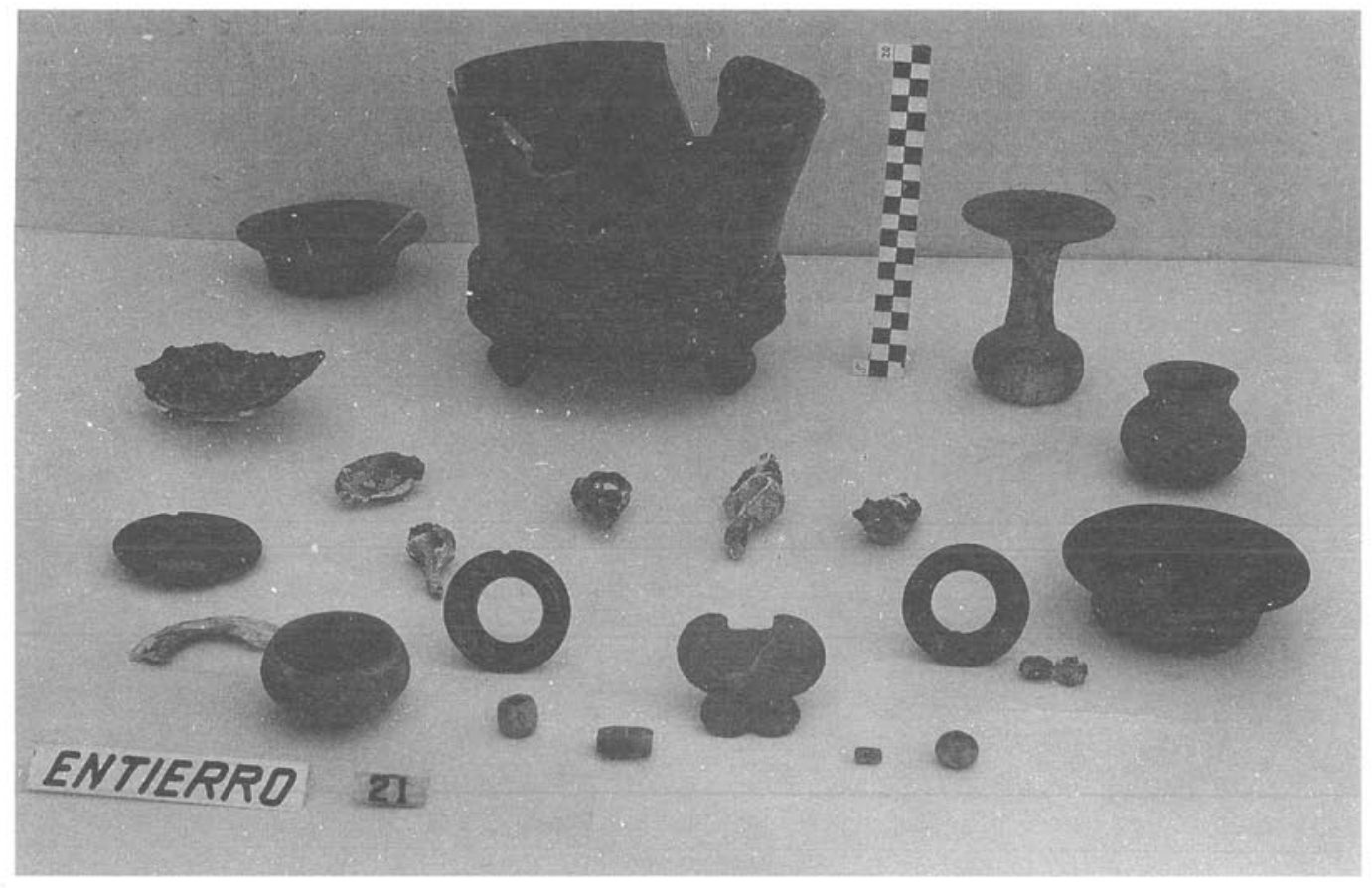

Plate IV: Offering from Early Tlamimilolpa Phase Burial 16, La Ventilla B compound. a. Painted Red-on-Natural miniature vase; b. Low Polish or Matte bowl (Vidarte 1964). 


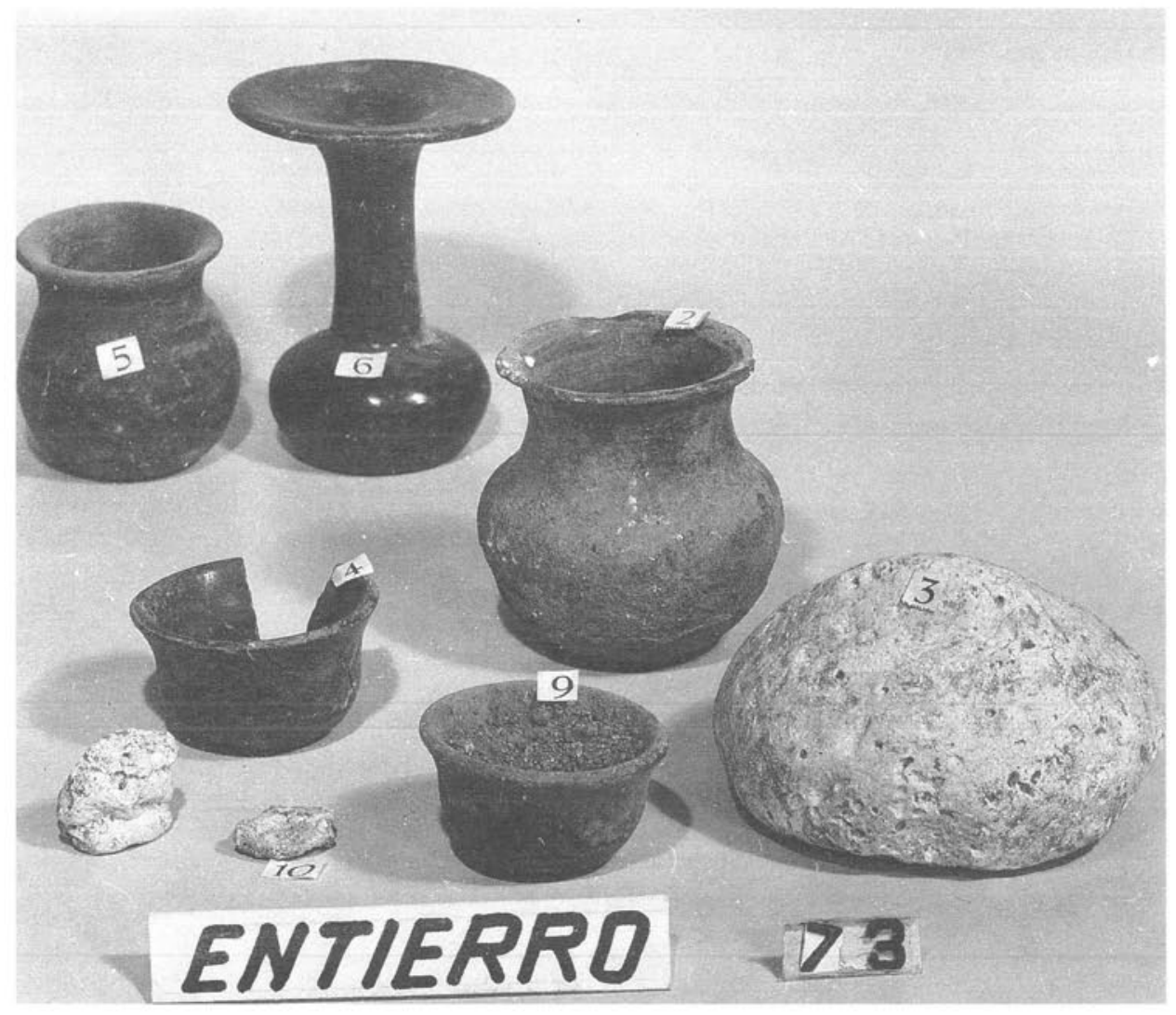

Plate V: Offering from Early Tlamimilolpa Phase Burial 73, La Ventilla B compound. Top row: two polished high neck jars; one polished black florero. Below: two polished upright bowls, one diatomaceous earth figurine, one ball diatomaceous earth. Photo by Vidarte. 


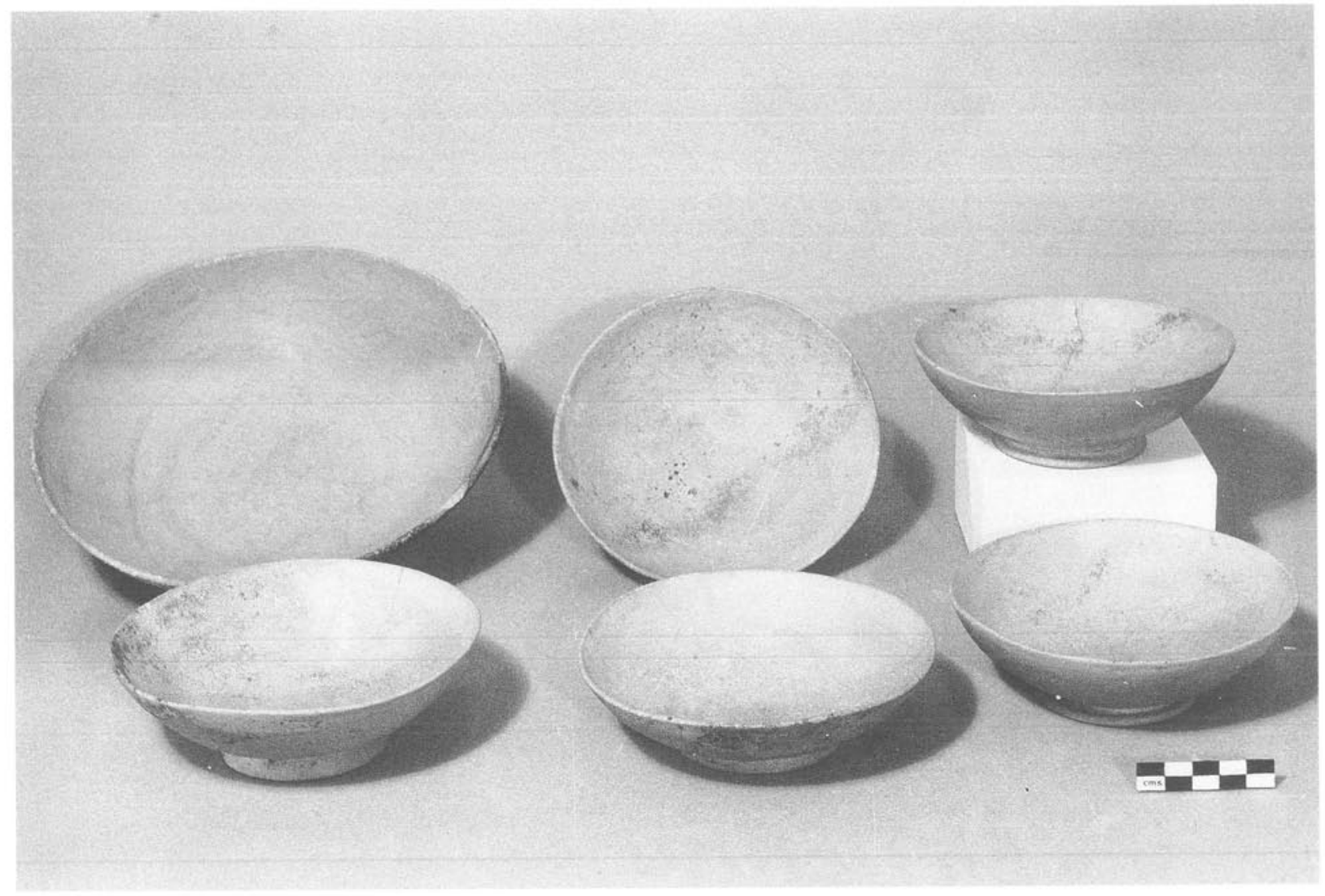

Plate VI: Offering from Early Tlamimilolpa Phase Salvage Burial III, La Ventilla B compound. Shown here are six of the eight Thin Orange ring-based bowls in graduated sizes. See inventory for remainder of offering. Photo by Reyes. 


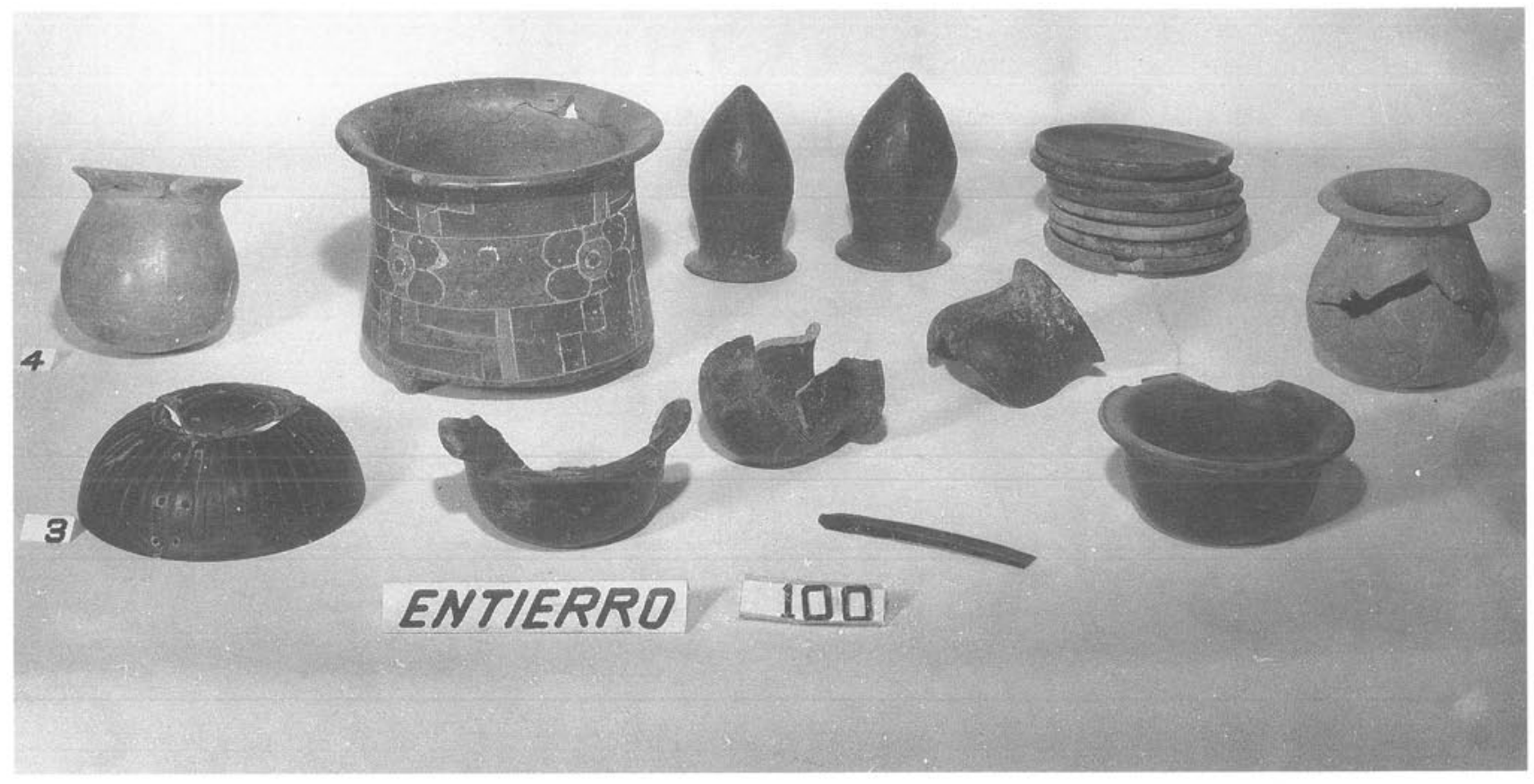

Plate VII: Offering from Early Tlamimilolpa Phase Burial 100, La Ventilla B compound. Short neck jar (4), Painted Red-on-Natural incised vase, Polished Black miniature amphoras, Polished Black groove incised bowl (3), and miscellaneous Matte miniatures. Photo by Vidarte. 


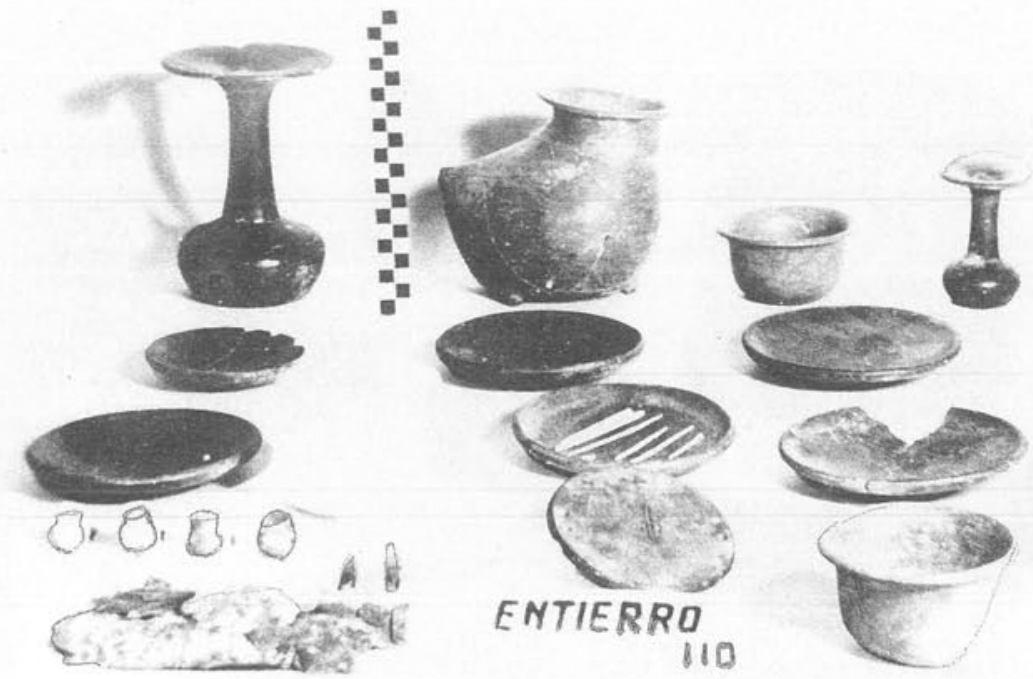

Plate VIII: Offering from Early Tlamimilolpa Phase Burial 110, La Ventilla B compound. Top row: Polished Black florero, patojo, recurved bowl, and miniature florero.

Below: Polished low walled plates, Matte miniatures, obsidian blades, pyrite disk with pecked cross design and Polished recurved bowl. Photo by Vidarte. 
"Patio 5", another Early Tlamimilolpa focus of burials, is a room with a portico (fig. 5c) facing a patio on the west. Its beginnings were in Early Tlamimilolpa times as evidenced by Burials 13, 16 (Plate IV) and 21 (Plate III) and Salvage Burials XVII, XVIII, XX, and XXXI, located in Patio 5A (possibly, the lower level of Patio 5: fig. 6). Patio 5 had a large pit, the "gran huella", where some richly stocked burials were recovered. An important individual, an adult male (Burial 21), was interred there (Rattray and Ruiz 1980: 108, fig. 1) with funerary offerings consisting of six ceramic vessels, a nosepiece of jadeite in the form of a butterfly, earrings finely executed in obsidian, jadeite beads, shell objects and pyrite disks. The exotic items once seemed to suggest the person was a merchant with access to wealth and appeared to bear out the hypothesis of Gulf Coast affiliations with this barrio (Piña Chan 1963). However, recent evidence from the Temple of Quetzalcoatl ties such offerings to a warrior cult (Sugiyama 1989). Burials 3 and 10 from Patio 5 were Late Tlamimilolpa in date, indicating continuity in residence. The skeletal material from Patios 5 and 6, studied first by Serrano and Lagunas (1975) for age, sex and pathological characteristics and later by Spence for "the distribution of anomalies in the population" (1971: 59) found a predominance of females (nine) over males (three) and a closer genetic relationship between the males than the females. Spence suggests that males in the La Ventilla B compound were engaged in obsidian working, a commonly male dominated activity. The absence of some males could be explained if they were the pochteca, the travelling traders, who went to Veracruz perhaps for shell materials (Piña Chan 1963).

Altar Room III located in the north-central part of the compound (fig. 6) is also Early and Late Tlamimilolpa in date. Burials 60,61 and 62 can be tentatively phased as Early Tlamimilolpa. Early Tlamimilolpa Burial 60, a young female, was accompanied by a fairly rich offering. Burial 61 is a child and Burial 62 held two infants, the first accompanied by two undiagnostic bowls, the second by Polished dark brown outcurving bowls with nubbins. A posterior use of Altar Room III is indicated by the two adult burials (Burials 58 and 59) that were unquestionably of Late Xolalpan date judging from the characteristics of the vessels.

The Adobe Room complex located on the east central side of the La Ventilla B compound is the locus of Late Tlamimilolpa Burials 41, 42, and 82 . Undated burials stocked with only Matte miniatures were Burials 20, 28, 43, 83, 97, 98, 105, 106 and 116. Burials with no artifacts were $67,78,79,80,84,85$, 99, and 108. Adobe Room 3 on the south contained almost exclusively Early Tlamimilolpa interments (Burials 73 [Plate V], 74, 75 [unphased], 76, 77, and 108 [unphased]). The individuals buried in Adobe Room 3 have been identified as five females, two males and one infant (Table 1) (Serrano and Lagunas 1975). An examination of the burial accompaniments shows males were not favored with richer items than females. Both had shell pieces, red painted slate pieces, unfired diatomaceous earth figurines and ordinary ceramic vessels.

Patio 1 West and the rooms to the west, south and east (fig. 6) had burials under the floors dating to Early Tlamimilolpa and Late Tlamimilolpa, then sporadic re-use from Early Xolalpan to Metepec times. Perhaps the most important single burial was Early Tlamimilolpa Salvage Burial III from Patio 1S, an adult male buried with two human skulls and a large ceramic offering that included eight Thin Orange vessels in graduated sizes, an imported ware from southern Puebla (Plate VI) (Rattray and Ruiz 1980: 109). Other Early Tlamimilolpa burials were represented by Burials 100 (Plate VII) and 110 (Plate VIII). Spence's analyses of the residential practices at La Ventilla B showed Patio 1 West to be the interment locality of males who were less closely related than the women, an unusual situation in the La Ventilla B compound that had predominantly male lineages (Spence 1971). Burials 87 and 88 (Late Xolalpan phase burials) located in Patio $1 \mathrm{E}$ are discussed below. 


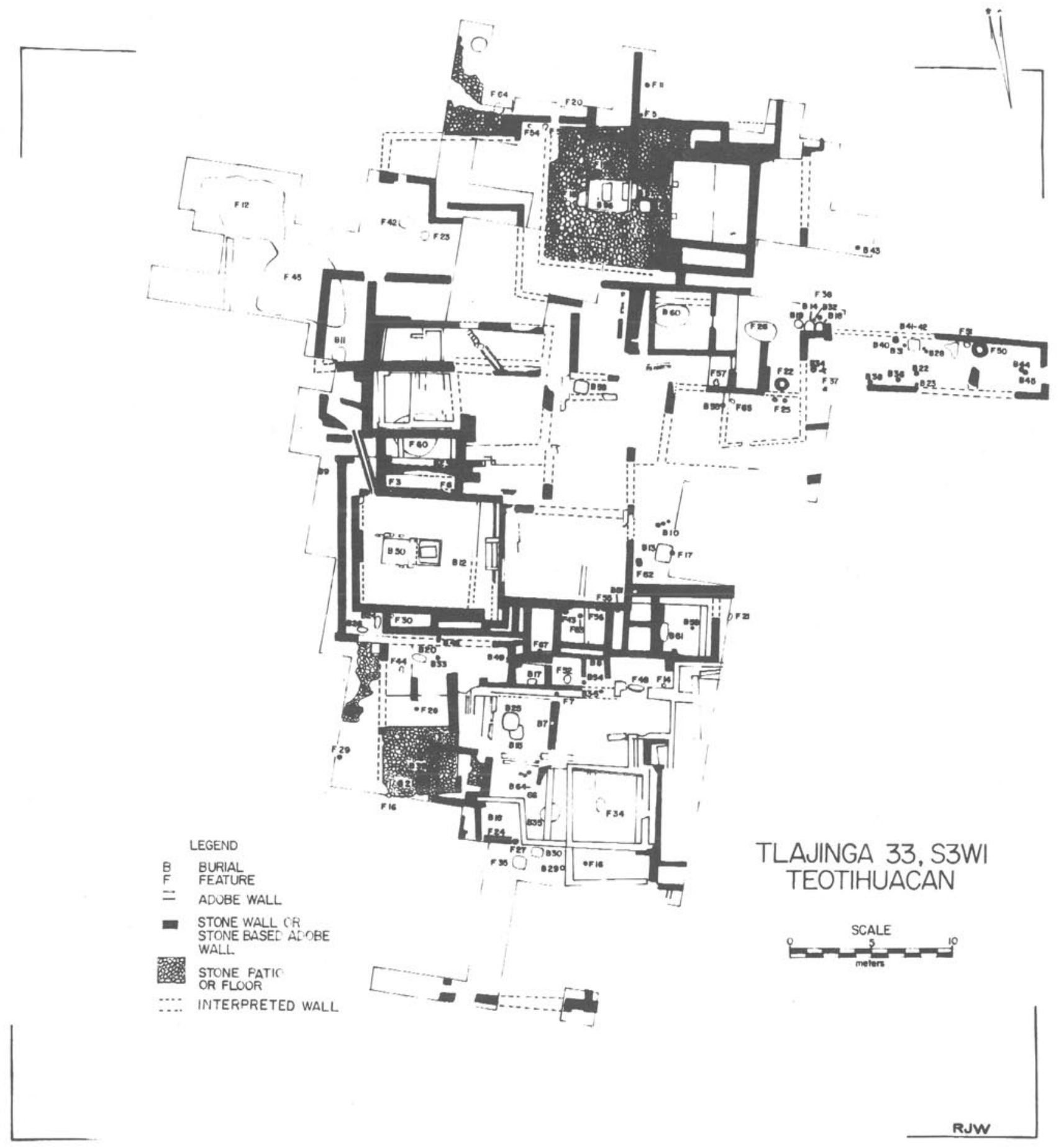

Figure 8: Plan of Tlajinga 33 showing Burial locations. Early Tlamilolpa Phase Temple shown on the north. From Widmer 1987a. Courtesy of Instituto de Investigaciones Antropológicas, UNAM. 
Tlajinga 33 Compound:

The excavations at Tlajinga 33 (fig. 8) were the first specifically designed to recover paleodemographic data on the skeletal materials of a Teotihuacan apartment compound. Storey (1985, 1987: 93) recovered over 100 individuals: 39 were primary burials with ceramic offerings, 13 were primary burials lacking offerings, 6 were secondarily deposited individuals with offerings and 12 other secondary burials had no offerings. In addition, Storey made the important discovery of 37 "refuse interments" or the scattered bones of individuals that she recovered not from graves but from garbage dumps and fill material used in building, which she says were "probably primary and secondary interments that were never reburied after being disturbed". Table 1 lists both the formal burials and the "refuse" burials. There were 68 burial episodes and the number of individuals involved was 107 (Appendix 1, Table 1). No clear cases of cremation were reported.

In the Early Tlamimilolpa phase the initial occupation of the site occurred and the major living and ceremonial area was located in the northeast corner of the compound (fig. 5) (Storey 1987: 100). The main focus was a cobblestone ceremonial courtyard and shrine room. An important, evidently high-status individual (Burial 56) with a rich ceramic offering had been buried in the shrine room. Subsequently, a second individual was interred in the eastern entrance to the shrine room. Storey says that without doubt the latter was the highest ranked individual in the compound at this time. On his death he was given a sumptuous burial with ceramic vessels and two greenstone beads and was wrapped in a robe embroidered with 4,000 olivella shells and a headdress consisting of two large ring-shaped rattlesnakes made of shell.

The ceramic offerings of the Early Tlamimilolpa phase at La Ventilla B and Tlajinga 33 are characteristically made up of Polished black vessels (floreros, low-walled plates, jars and distinctive outcurving bowls with flat bases and nubbin supports), usually of high quality workmanship. Tlalocs are an intriguing offering in the early burials and one of the few items that give an insight into the religious customs. (The diatomaeceous earth figurines may be another.) No Tlaloc jars and only a few Thin Orange vessels were recovered in the Tlajinga 33 burials.

A clustering of interesting characteristics, the patojo, florero, and green obsidian, pertaining to the mortuary offerings of three male adults (Early Tlamimilolpa Burials 87 and 110 [Plate VIII], and one transitional burial, Burial 10) were distributed in different parts of the compound. Chadwick, in his study on New World merchants (1974), says this combination of traits is representative of groups of foreign traders related to the ancient concept of the "Q Complex" proposed by Valliant (1941). The attributes of this complex are usually the above-mentioned items and Thin Orange effigies. Chadwick thinks that the appearance of this merchandise at $\mathrm{La}$ Ventilla B is indicative of the presence of such individuals at Teotihuacan.

By way of summary, in the Early Tlamimilolpa phase, "Patio 5" (a temple), Patio 1E and Altar Room II, and Adobe Room South were the formal disposal areas for three different corporate groups probably practicing patrilineal descent as Spence (1971) suggests. Possibly each architectural unit corresponded to an extended family.

One of the individuals in the Patio 5 group (Burial 21 Plate III) seems to have enjoyed a status above the others, as is evident from the exotic goods in his interment. Burial 96 of Patio 1E and Salvage Burial III (Plate VI) and Burial 110 (Plate VIII)--the latter two related to Altar Room III--also stand out for their offerings. The Adobe Room burials (Burials 73 [Plate V] and 77) consisting of five females, two males and a child were not outstanding for their burial contents. 
La Ventilla B in the Early Tlamimilolpa phase continuing into Late Tlamimilolpa seems to have enjoyed greater prosperity than at any later time. Contemporaneous individuals were buried at the Tlajinga 33 compound and honored with unusually exotic items (Burials 56 and 57, fig. 8).

Intermediate between the temple constructions and the simple habitational platforms are the Ciudadela Palaces. They are the earliest known at Teotihuacan and may have been in existence since the end of the Miccaotli phase. The construction of the Temple of Quetzalcoatl was initiated in Miccaotli times and could indicate a shift from the ideology and politics of the Sun Pyramid priests to a powerful new group of priest-rulers centered at the Ciudadela, or possibly the co-existence of two powerful competing groups.

Early Classic Period Burial Patterns:

Late Tlamimilolpa-Early Xolalpan Phases

Profound changes take place at the beginning of the Late Tlamimilolpa phase, changes that must have had incipient beginnings in Early Tlamimilolpa but are now thorougly recognizable. A shift in emphasis from monumental building of pyramids and temples to greater emphasis on elite housing and family shrines continues.

In this phase, public religious activities no doubt still centered at the main monuments, the Pyramid of the Sun, the Pyramid of the Moon and the Temple of Quetzalcoatl. Many three-temple complexes along the Avenue of the Dead were built over and enlarged (Cabrera 1987; Angulo 1987). The Calle de los Muertos complex was entering a second period of construction with modifications in the use of space, such as the incorporation of habitations where previously had existed plazas and patios. The five or six three-temple complexes were incorporated and absorbed into the new plan (Morelos 1985). From what had been two major ceremonial zones that dominated Teotihuacan, the Sun and Moon Plaza on the North Avenue and the Great Compound-Ciudadela complex on the south were now integrated with the Calle de los Muertos complex. Palace-type structures spread throughout the city and other complexes were built over and raised to the Calle de los Muertos level (ibid.). By Early Xolalpan times, extensive rebuilding took place along the main avenue, extending south to the Ciudadela.

An overwhelming amount of data on burials is available for the Early Classic Period, reflecting the enormous complexity of Teotihuacan society at this time. Of the many themes that govern the life of Teotihuacanos we restrict our discussion here to the aspects related to their mortuary behavior. The richness and variety in Late Tlamimilolpa-Early Xolalpan ceramics testify to this phase as being one of the most creative and dynamic in Teotihuacan's long existence as well as the period of greatest contacts and expansion throughout Mesoamerica.

Three or more ethnic barrios at Teotihuacan, the Merchants' Barrio with its Gulf Coast-Maya affiliations, the Zapotec Barrio with its Oaxacan affiliations, and the La Ventilla A and B Barrios with their Gulf Coast affiliations become recognizable archaeologically as separate entities with distinctive traits. By Early Xolalpan these barrios are fully established and apparently involved in intensive interaction with their respective homeland regions. A region that enjoyed continuous, intensive contact with Teotihuacan was the Tepexi de Rodríguez, Southern Puebla region, where the important trade ware, Thin Orange, was manufactured. The descendants of the Popoloca peoples, thought to be the manufacturers of the ware (Cook de Leonard 1957c), almost certainly maintained their own ethnic barrios at Teotihuacan to administer the distribution of the ware and accomodate for the enormous volume of pots arriving in the city. The "Old City" is one possibility, due to its large concentrations of the ware, and an area west of the Pyramid of the Sun is another, judging from the ceramic concentrations as revealed by computer maps (Cowgill 1981). Thin Orange is extremely abundant at the Merchants' Barrio, comprising up to $25 \%$ of 


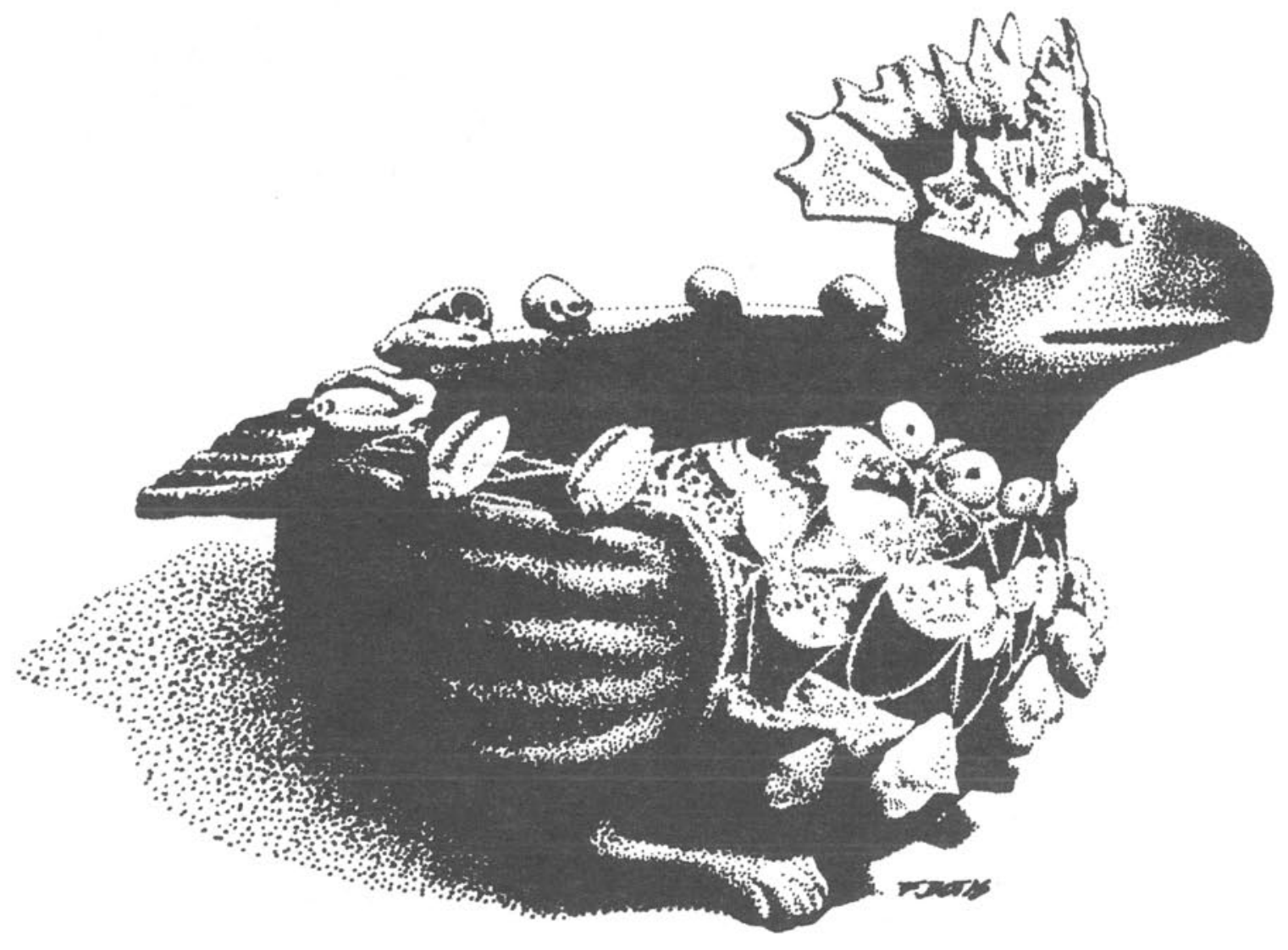

Figure 9: Bird Effigy from Burial 66, La Ventilla B. Profusely decorated with shells. Eyes are of jadeite. Drawing by Botas. 

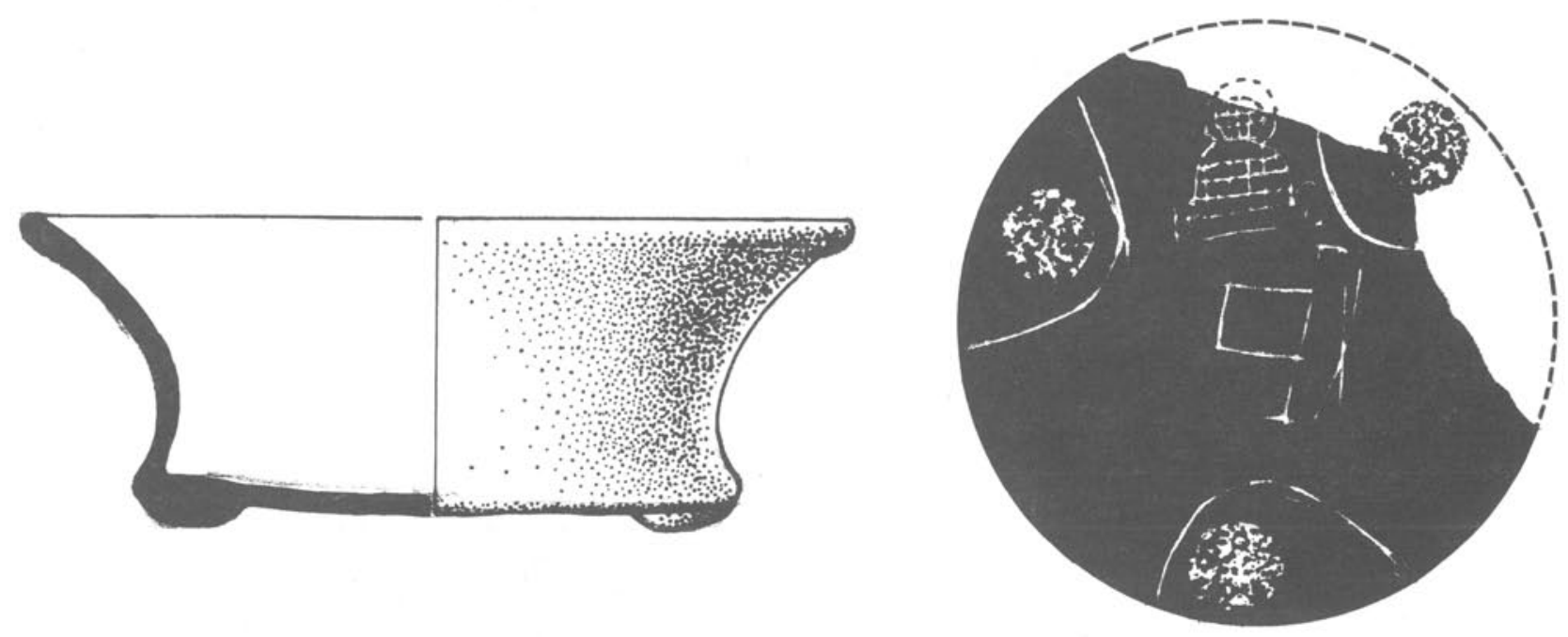

a. Polished black outcurving bowl

b. Bulto and altar on bottom
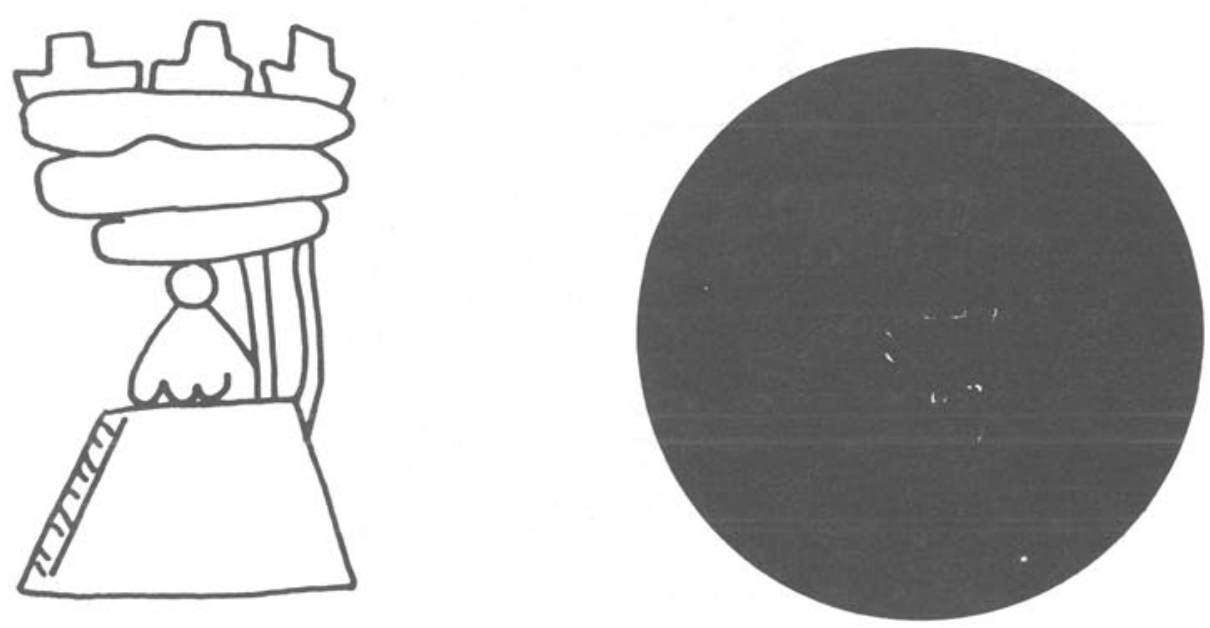

c. Temple with bulto

d. Bowl with design

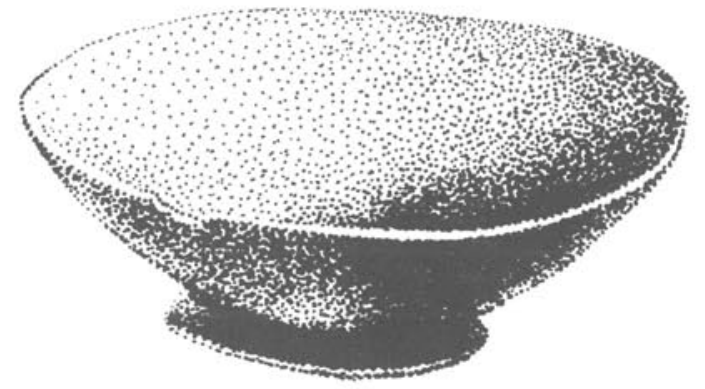

\section{- Polished brown ring base bowl}

Figure 10: Early Tlamimilolpa and Metepec Phase bowl offerings with graffiti depicting wrapped corpses. a. Polished Black outcurving bowl from Tlajinga 33 with "bulto" and altar drawn on the base; b. Metepec Phase Polished Brown ringbase bowl from Pueblo Perdido; c. Temple with "bulto" design on interior of bowl; d. bowl interior; e. view of ringbase bowl. 
some Early Xolalpan deposits. In Late Xolalpan times the Coarse Thin Orange amphoras (cantaros) make up much of the volume at the Merchants' Barrio. At the Oaxaca Barrio, industries involving the use of Coarse Thin Orange amphoras as liquid containers had developed (Rattray 1979, 1987b).

\section{La Ventilla A and B Compound:}

In the Late Tlamimilolpa phase at La Ventilla B there is considerable evidence for continued use of the same areas for disposal of the dead, such as Patio 5, Patio 1 East, and Patio 1 West. Adobe Room 3 seems to have been abandoned and a group of connected rooms just to the north was built. These burials are rich and varied with new traits such as painted specular red vases and cajetes, polished spouted cups and cylindrical tripod vases appearing. Thin Orange from Southern Puebla becomes more common. The shell offerings in the La Ventilla B burials of Early and Late Tlamimilolpa are particularly notable. Our data (albeit incomplete) show shell offerings in Early Tlamimilolpa Burials 21, 88, 110 and Salvage Burial IX and Late Tlamimilolpa Burials 3 and 66. A burial of great interest, probably the wealthiest at the compound and with the most shell, is Burial 66 (Plate IX) that was located in Patio 1E, Room 1. Perhaps the individual interred there was a shell merchant or artisan, as his offering contained a stone palette and tools, shell beads and a strange bird effigy decorated profusely with shells and jade incrustations for the eyes (fig. 9). (Jade is extremely rare at La Ventilla B, occurring only in Burials 21 and 66.) The bird effigy's ruffled feathers, represented by shells, and its curved beak, indicate it is a bird of prey such as an eagle or an osprey, the latter a coastal bird which is an appealing assumption because of the aforementioned possible Veracruz relationships.

Teotihuacan was the recipient of strong Gulf Coast infiltration in the Early Xolalpan phase as evidenced by the "Terrazas Lustroso" and Lustrous Ware vessels (Plates X, XI, XII) from Teotihuacan graves that were coming in from the El Tajín region. ${ }^{8}$ At the Merchants' Barrio also it was the time of most intensive interaction with southern Gulf Coast sites, the most common import from there being the Fine Paste Orange, Cream and Gray wares (probably from the Tuxtlas region) and almost no Lustrous ware, indicating control over different wares by the pochteca (merchants) originating from different sites on the Coast.

The Tlajinga 33 Compound:

The burial pattern of the Late Tlamimilolpa-Early Xolalpan phases at Tlajinga 33 (fig. 8) was somewhat different from the previous one. The settlement shifted to the south to a new ceremonial courtyard where the burials were then located (Widmer 1987a). There may have been two subgroups or sublineages as evidenced by the two distinctive activity-discard areas associated with the burial concentrations in the Enclosed Yard and those located to the very south of the compound (Storey and Widmer 1989). Burials are located under the rooms and walls and not in the main courtyard as in the Early Tlamimilolpa phase. This phase accounts for the largest number of dateable burials and the most elaborate offering-accompanied burials. Infants and perinatals were buried under altars and do not seem to have been sacrificial victims. An unusual grafitti-decorated basal incurved bowl of Early Tlamimilolpa style from this compound depicts a bulto (burial bundle) associated with an altar on the outside bottom (fig. 10b).

\section{THE ETHNIC BARRIOS:}

The primarily non-elite group who established a foreign enclave at Teotihuacan on the western fringe of Teotihuacan about 200 A.D. were Zapotecs (Rattray 1987a, Spence 1989) who maintained their identity intact for a period of 300 years or more. The physical layout of the community consisted of typical Teotihuacan apartment compounds with one or more temples each (fig. 11). As seen from 


\section{Plan of excavations in site 7:NIW6. Teotihuacan TLAILOTLACAN,OAXACA BARRIO \\ TMP(TE3; TE3A)AND UNIVERSITY OF THE AMERICAS}

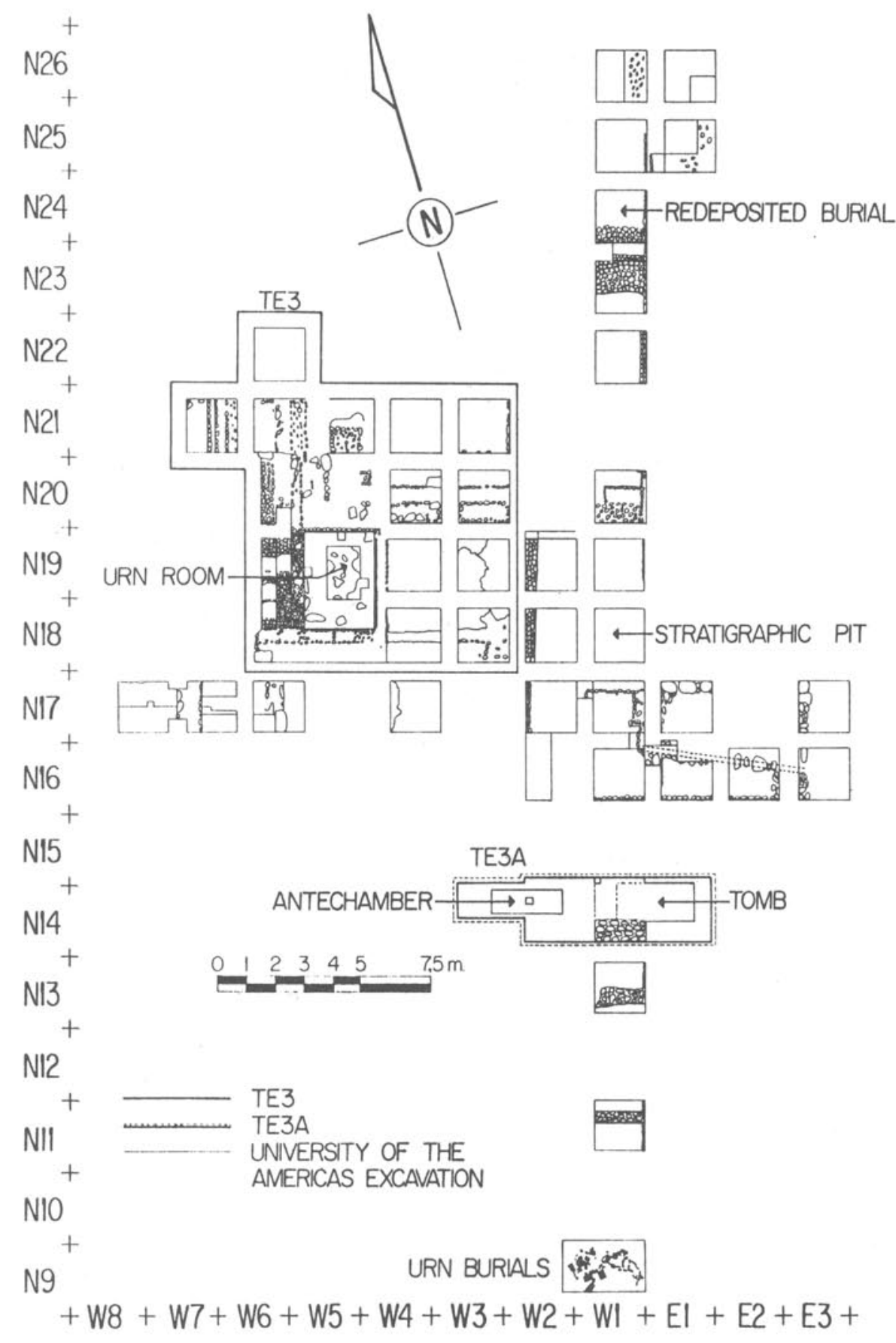

Figure 11: Plan of Excavations in Site 7:N1W6, Oaxaca Barrio: University of the Americas and Teotihuacan Mapping Project 


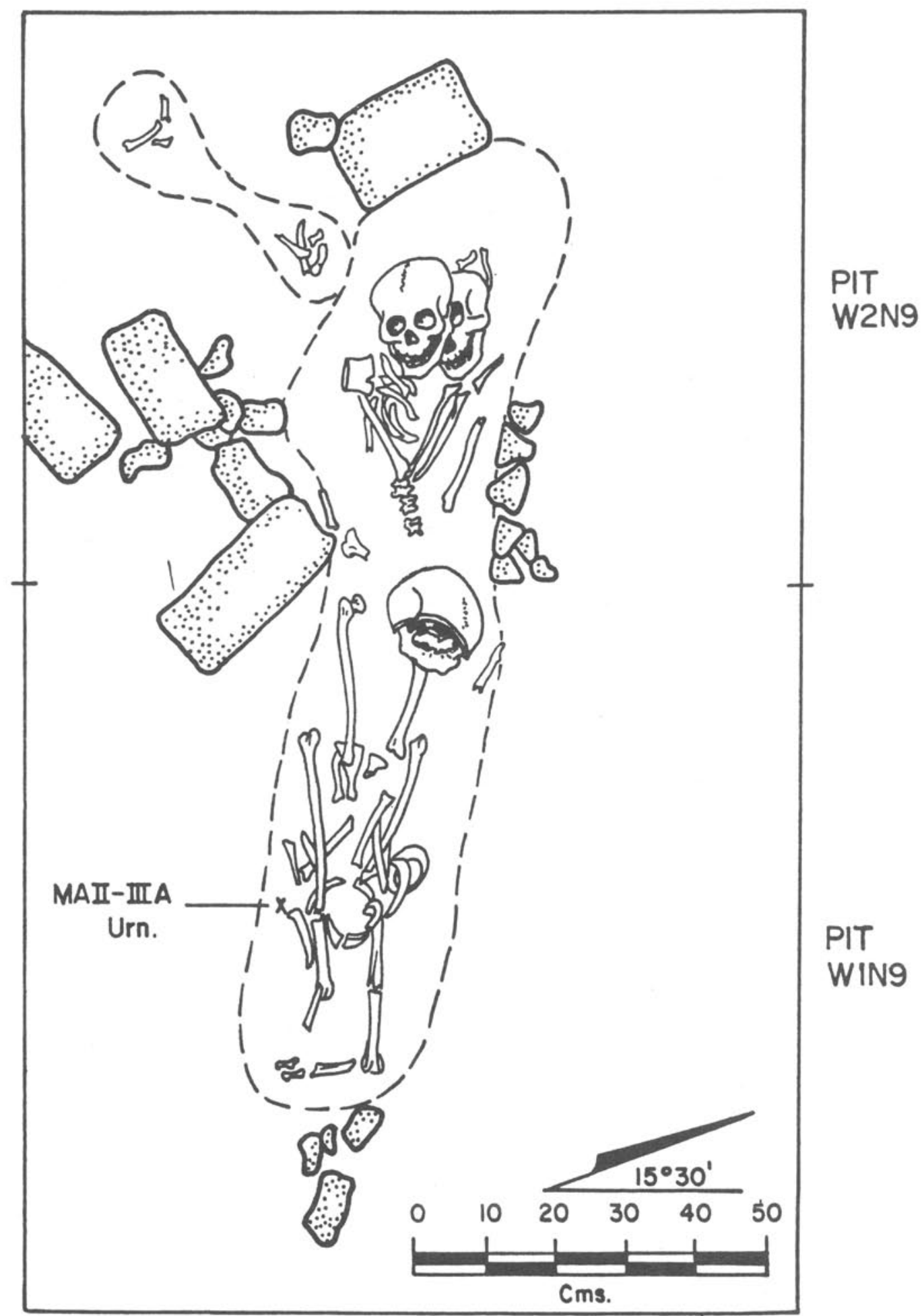

Figure 12: Plan of Extended Burials A1, A2, A3, and A4, which were accompanied by the Monte Alban II-IIIA urn. University of the Americas excavations at the Oaxaca Barrio in 1966, Pits W1N9-W2N9. 

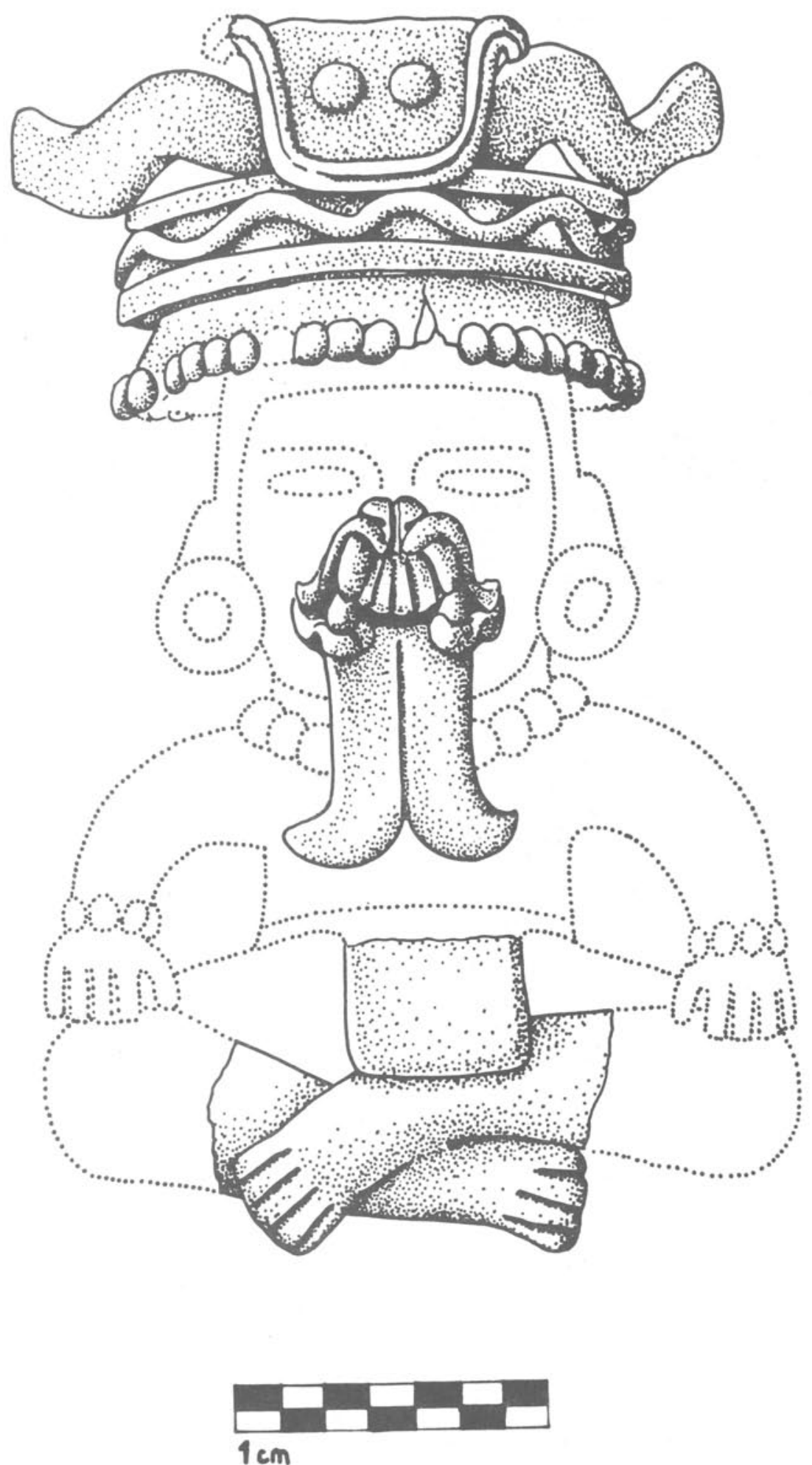

Figure 13: Monte Albán II-IIIA Urn from Pits W1N9-W2N9, Late Xolalpan Phase Burial A. University of the Americas Excavation at the Oaxaca Barrio. Drawing by F. Bagot. 
Oaxaca Barrio: South Profile, Pit EINI7

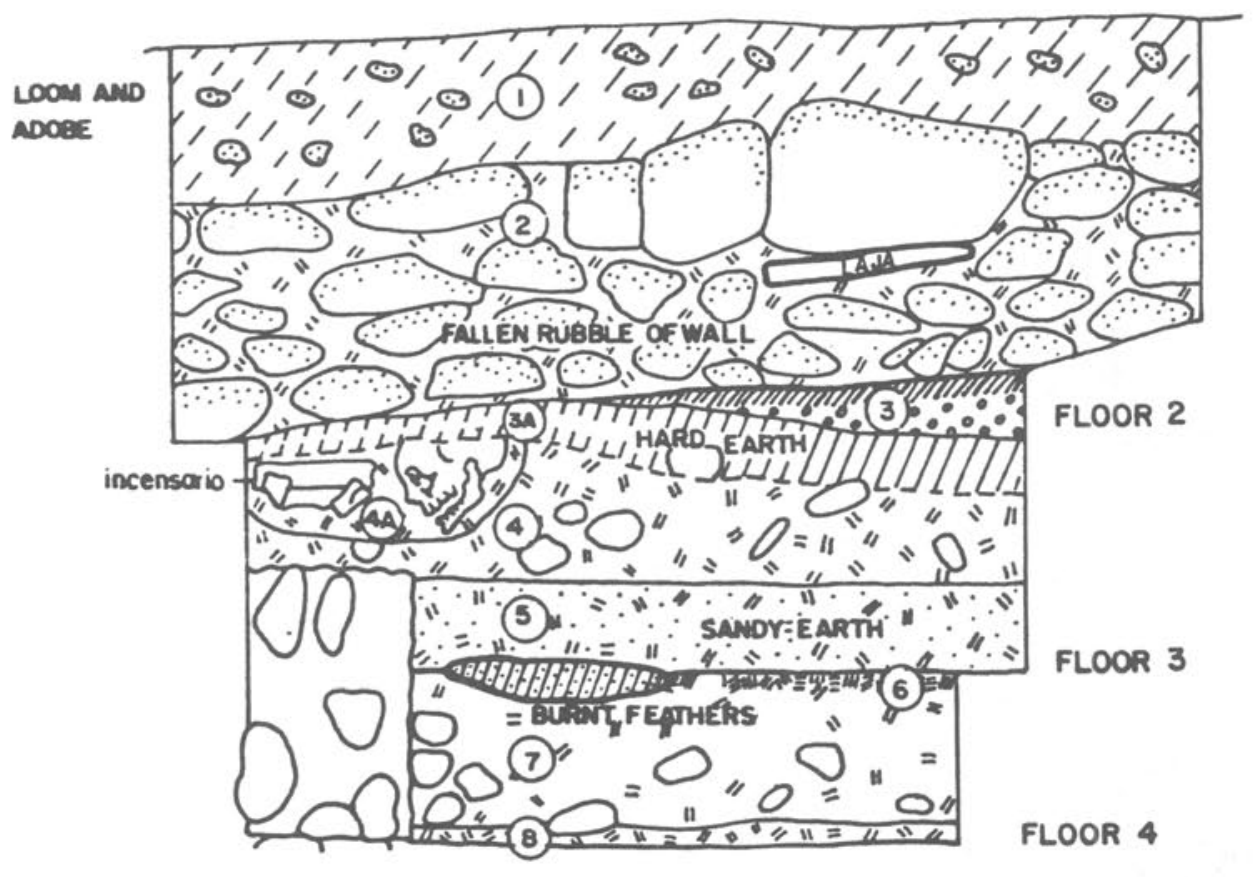

PLAN OF INCENSARIO BURIAL C

PIT EINI7, Loyer 40

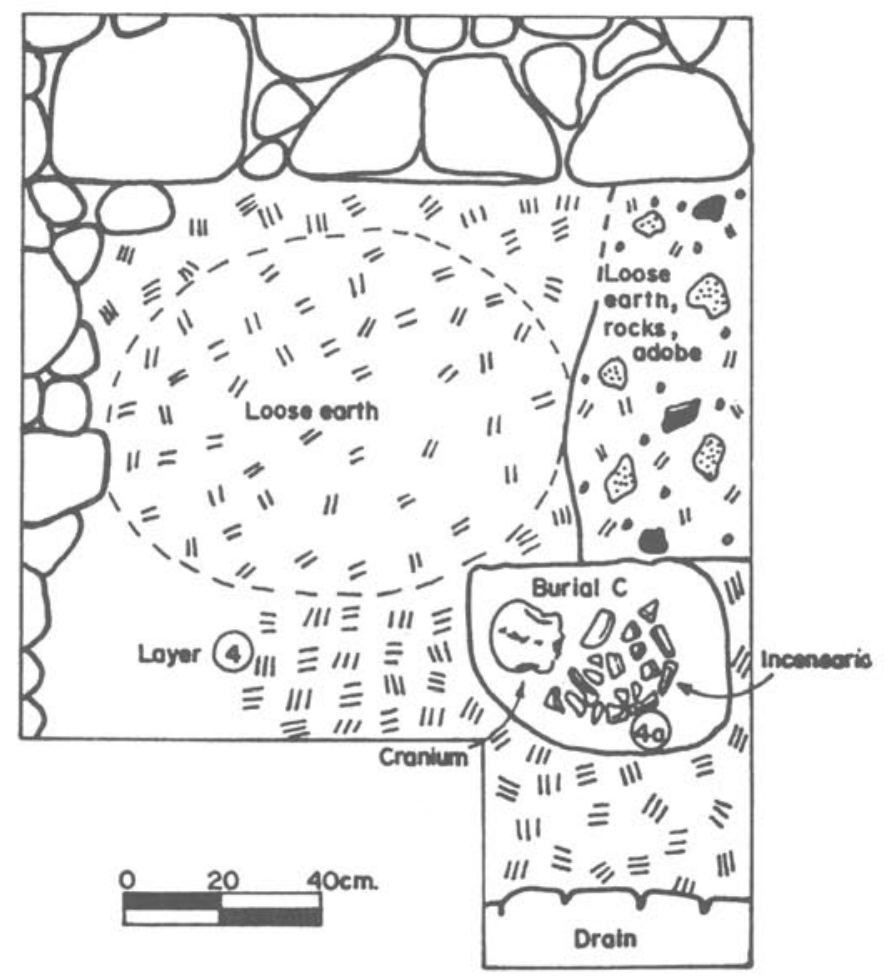

SOUTH PROFILE

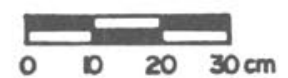

Figure 14: Plan and South Profile of Skull Burial C1 associated with Early Xolalpan Phase Incensario, Oaxaca Barrio, Pit E1N17. 


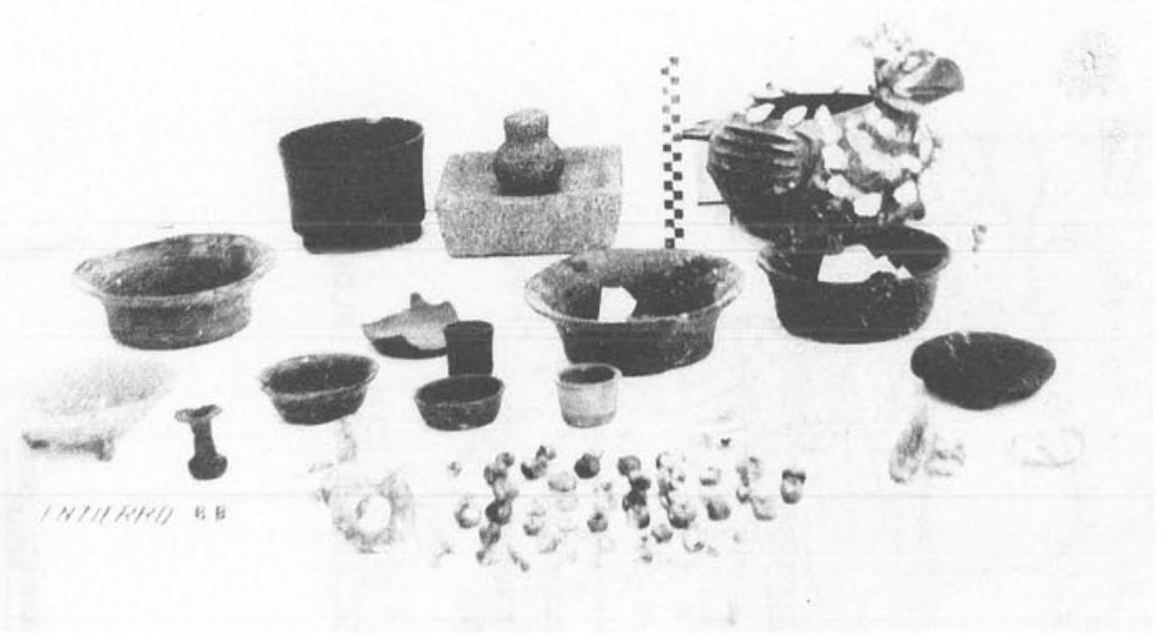

Plate IX: Offering from Late Tlamimilolpa Phase Burial 66, La Ventilla B compound. Burial of a possible shell worker was accompanied by: above, a small cylindrical vase, a stone palette with pestle, a bird effigy profusely decorated with shells;

below, Polished outcurving bowls, a Polished miniature florero, various Matte miniatures, and numerous shell beads. Photo by Vidarte. 


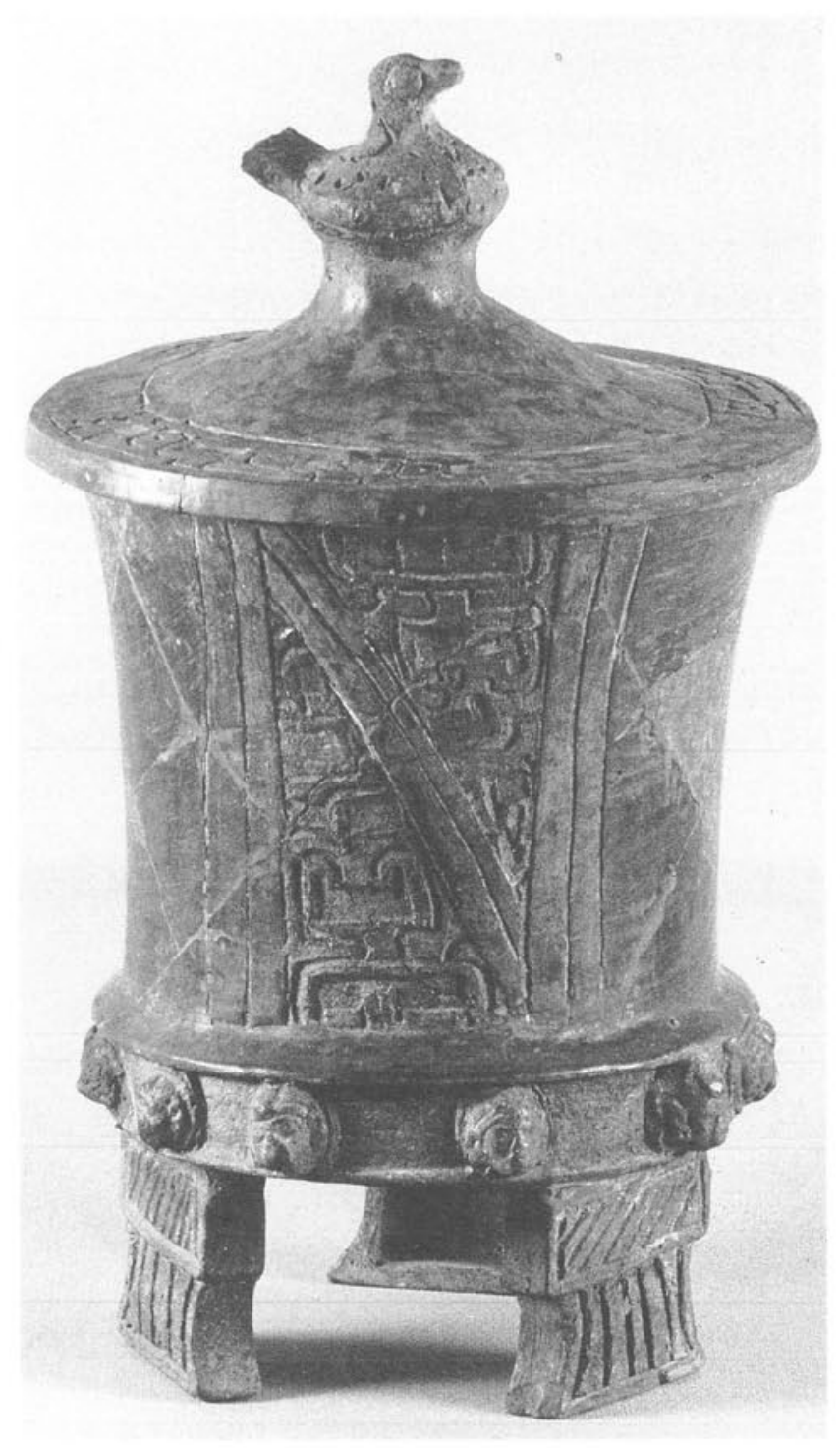

Plate X: Early Xolalpan "Kaminaljuyu Style" cylindrical vase (probably foreign). Lustrous ware with low relief scroll design, fine diagonal fluting, and monkey adornos. From La Ventilla A, Teotihuacan, Structure III, Room 5, Burial 1 (Kidder, Jennings, and Shook 1946, Figure 193). 


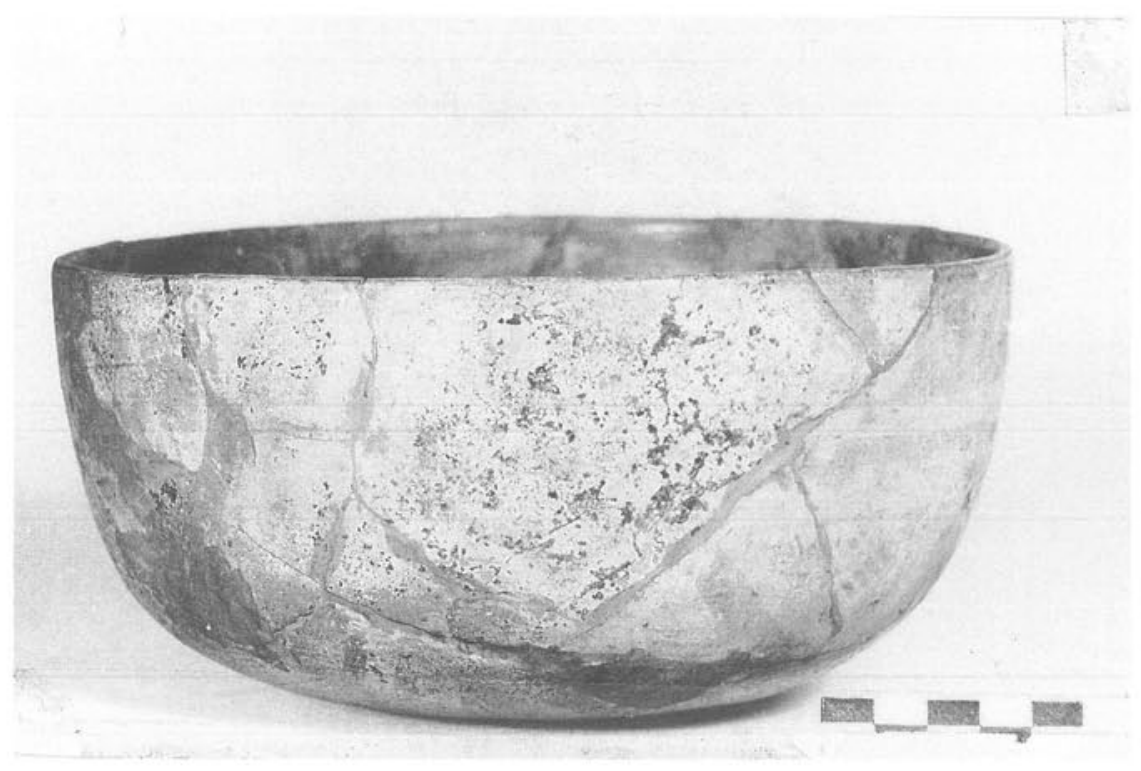

Plate XI: Offering from Early Xolalpan Phase Burial 3, La Ventilla A. Fine Paste "Terrazas Lustroso" bowl with negative design on cream backgound and orange "double-slipped" interior originating from El Tajin or vicinity. 


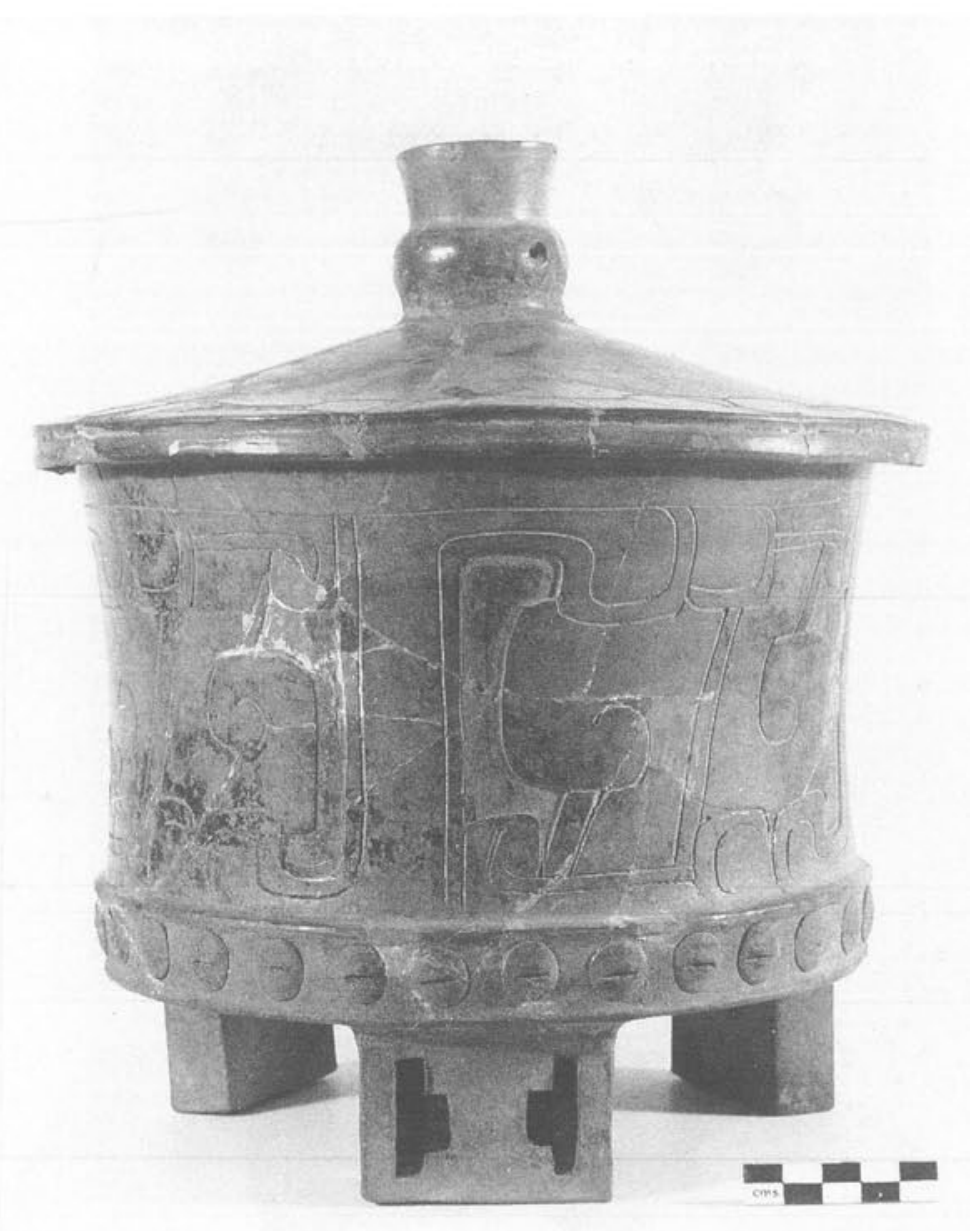

Plate XII: Late Tlamimilolpa Phase Lustrous Ware Vase originating from El Tajin or vicinity with apron lid from child burial north of the Rio San Juan. Noguera's "extroardinary find" (1955, Figure 13). 


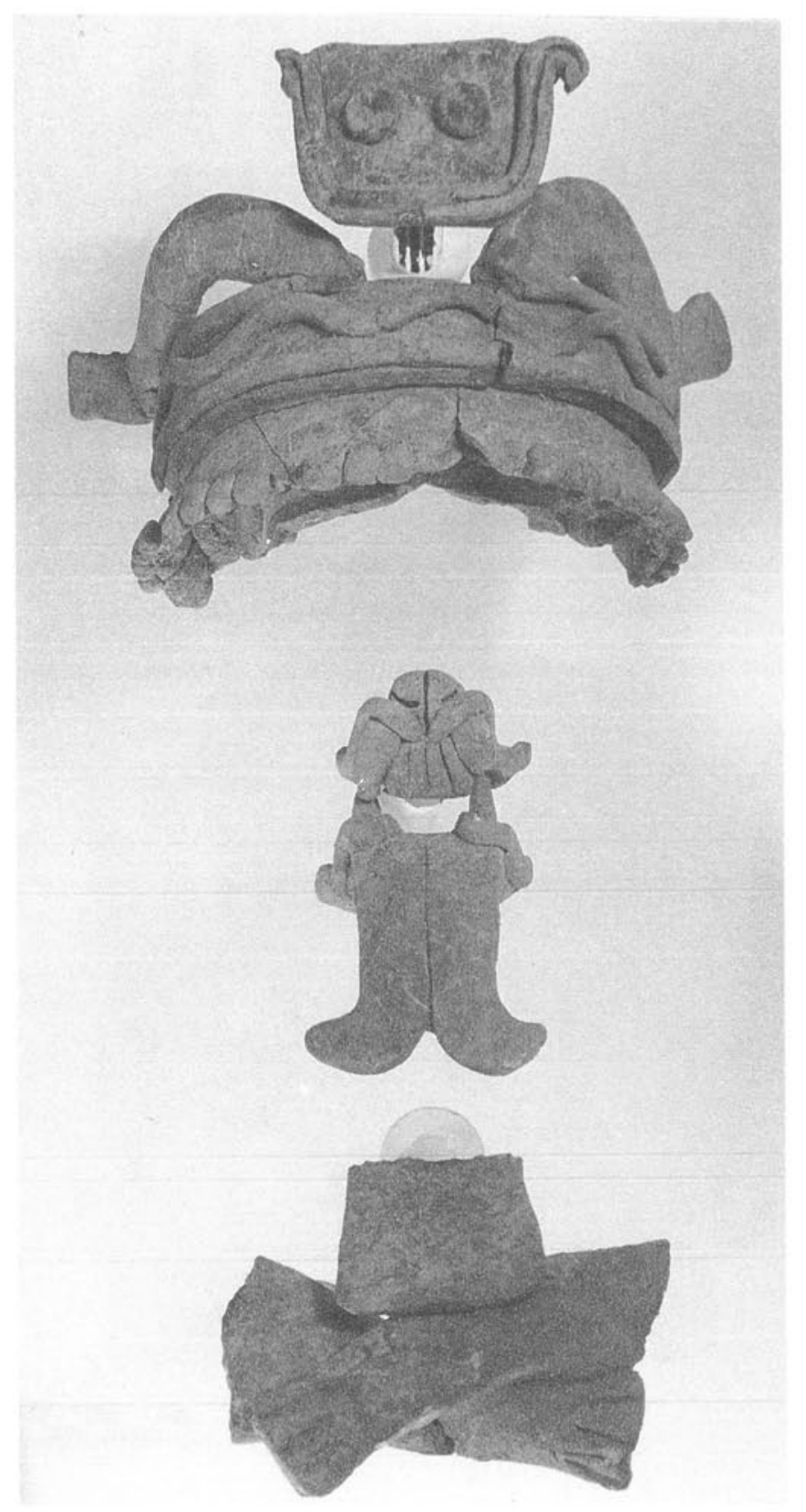

Plate XIII: Monte Alban Transition II-IIIA Urn from Pit W1N9-W2N9, Late Xolalpan Phase Burial A1. From excavations by University of the Americas at the Oaxaca Barrio. 


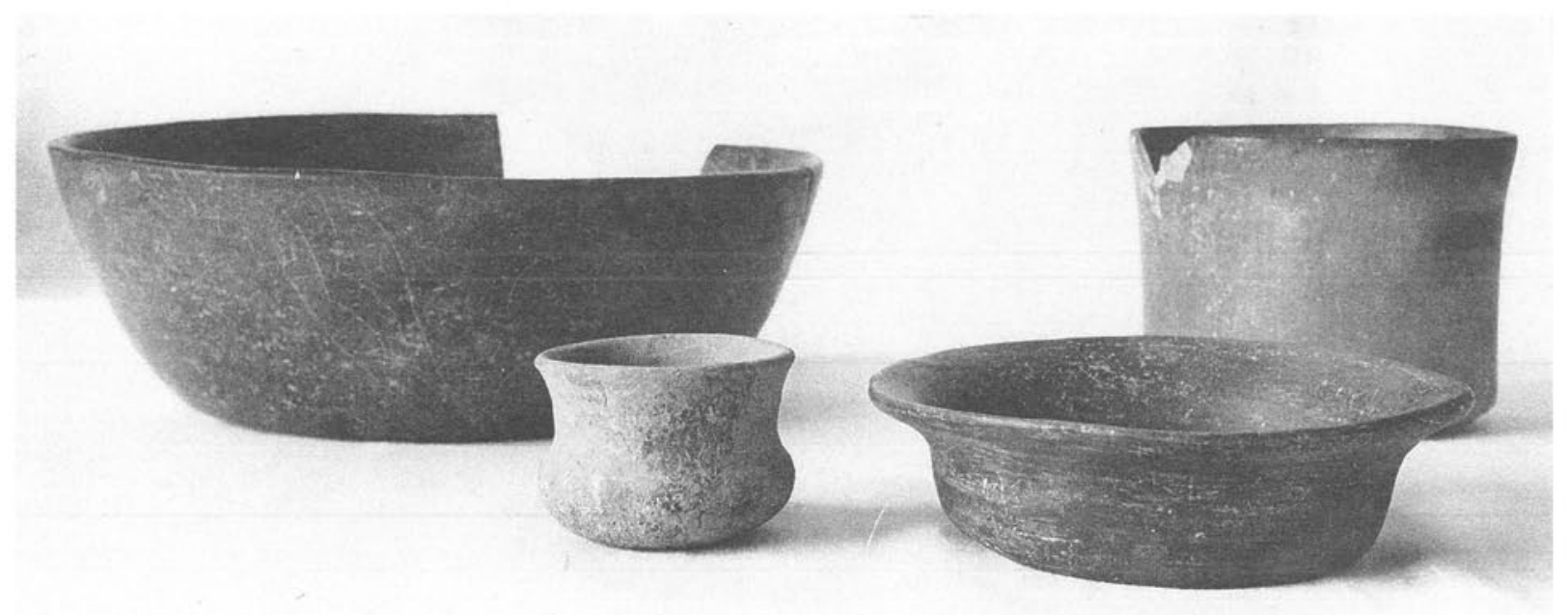

Plate XIV: Late Xolalpan Phase Offering of Teotihuacan vessels associated with extended Burials A1, A2, A3. Above: Polished and finely incised upright bowl and Copa ware vase; Below: Matte miniature ollita and Low Polished outcurving bowl. 


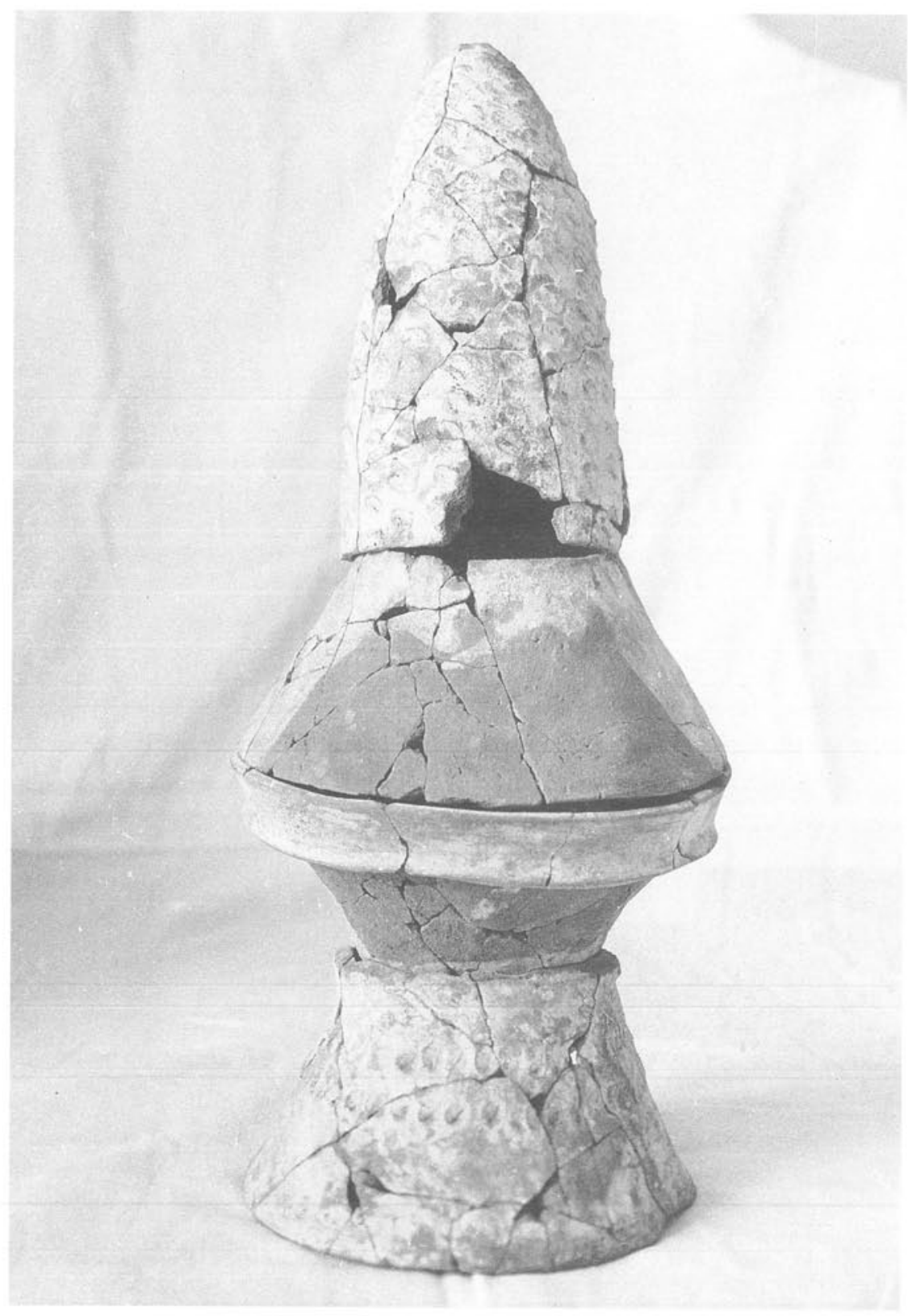

Plate XV: Early Xolalpan Phase Incensario included in Burial C, Pit E1N17, Oaxaca Barrio. The Incensario has "thumbnail" impressions on the chimney and base possibly representing corn ("elote" decoration). 
excavations, the Barrio does not have the appearance of a poor neighborhood. On the other hand it is far from luxurious and the burial offerings are quite ordinary with the exception of the imported funerary urns (Rattray 1989a). Serving symbolic and religious functions are the Monte Albán style tombs, stelae, figurines, urns and miniature effigies. Locally-made Fine Gray bowls and jars, as well as the important Fine Gray wares were used at the Barrio. Of obvious utilitarian nature are the Coarse Matte sieves and jars and the large apaxtles (tubs), the latter appearing exclusively at the Oaxaca Barrio and in quantity at several compounds just west of the Great Compound marketplace, where there seem to have been stockpiles of goods of all kinds. A clue to the role played by the Zapotec enclave at Teotihuacan comes from the related communities with similar attributes in the regions north of Tula whose inhabitants may have been involved in trading relationships with Teotihuacanos and other regions. At Chingú, the Oaxaca-Teotihuacan community was probably supplying Teotihuacan with food products and lime for building and was strongly dominated by Teotihuacan, as evidenced by architecture, pottery and figurines (Díaz 1981: 110).

Ethnicity was clearly expressed in the mortuary customs practiced by the Zapotec group residing at Teotihuacan. At the south end of the excavation we found a Late Xolalpan grave with three extended individuals (fig.12: Burials A-1, A-2, and A-3) associated with a Monte Albán Transition II-IIIA urn (fig. 13, Plate XIII; Caso, Bernal and Acosta 1967) and Teotihuacan pots (Plate XIV). Toward the northern extreme of the apartment compound a secondary burial under a floor was associated with the headdress only of a Monte Albán Transition II-IIIA urn and loincloth (Rattray 1987a: fig. 2h, 1). In addition, there were throughout the fill Oaxacan-style ceramics and figurines amounting to $5 \%$ of the recovered ceramics. Regarding the ceramics, Paddock (1983) says:

Every sherd of Oaxaca style that I know from the Oaxaca Barrio fits without forcing into a Transición II-III date at Monte Albán (though nearly all of them were produced at Teotihuacan from local clay). There are three classes of diagnostics that mark Transición: Period II ceramic types, Transición urns, and Period IIIa ceramic types. The Oaxaca Barrio materials include all three.

\section{THE EARLY XOLALPAN INCENSARIO OFFERING:}

In an east room toward the center of the compound (fig. 11, Square E1N17) under two floors we found an incensario associated with Skull Burial C (fig. 14, Plate XV). The skull was that of an adult, probably a female (Spence, personal communication 1988). We have determined the date of this burial to have occurred in Early Xolalpan times, both from the stylistic aspects of the censer cone (Plate XV) and the sherds surrounding it and in the deposits below the cranium of Burial C1. ${ }^{9}$ Skull burials are probably Teotihuacan-related and point out the nature of this barrio, incorporating both Oaxacan and Teotihuacan traits. Spence (1988) reports an Early Xolalpan adult burial with an offering from the Patio Hundido consisting of a Oaxacan-style sahumador (ladle censer), a Miccaotli florero, a Tlamimilolpa fluted jar, and a remarkable series of Thin Orange miniatures (including a vase with a stamped design, bowls, an ollita, jars and amphoras).

The first Oaxacan tomb and antechamber at Teotihuacan to be discovered (Millon 1967) was typically Oaxacan in construction. The entrance had two door jambs, one of which had been robbed. The in situ stone jamb was inscribed with Zapotec glyphs. The tomb offering as reconstructed from the archaeological evidence (Rattray 1979) contained both Teotihuacan and Oaxacan artifacts pertaining to the Early Xolalpan through the Metepec phases. The skeletal material revealed four adults, at least three of which had been painted with red pigment after the decomposition of the flesh (Spence 1976). 


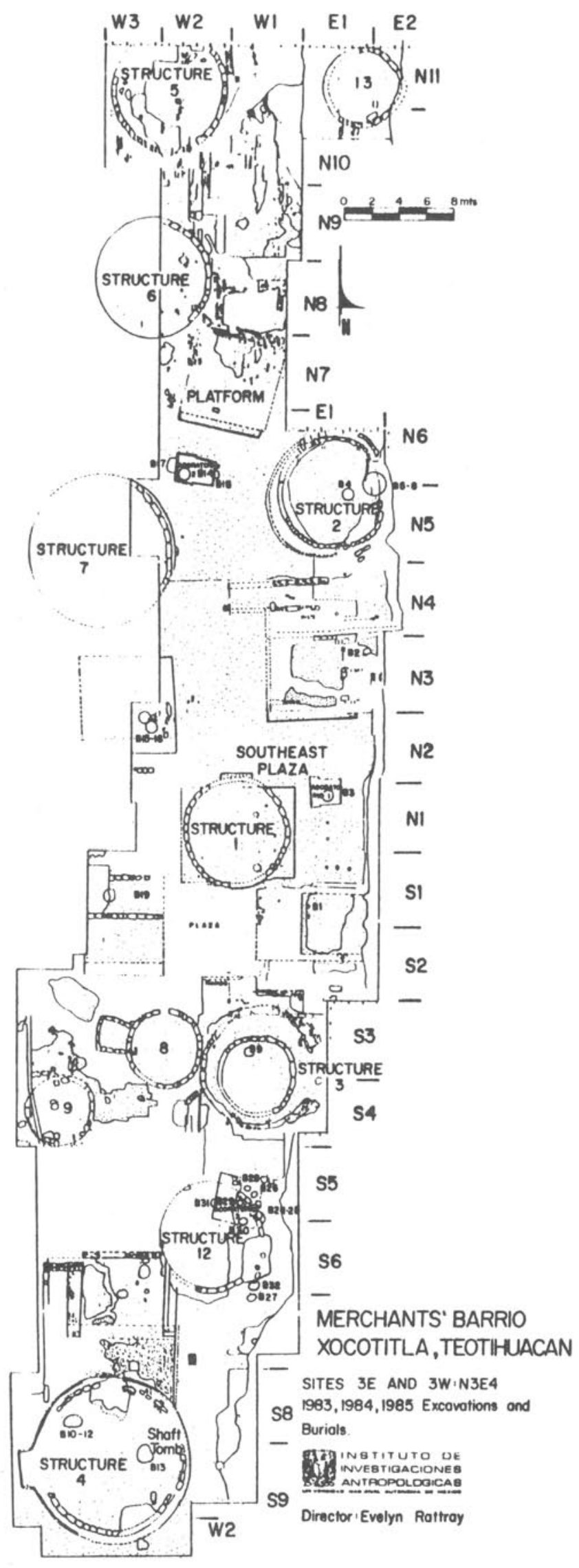

Figure 15: Plan of Merchants' Barrio in the northeast of Teotihuacan. Circular houses alternating with Platforms in the Xocotitla district. Burial locations indicated. 


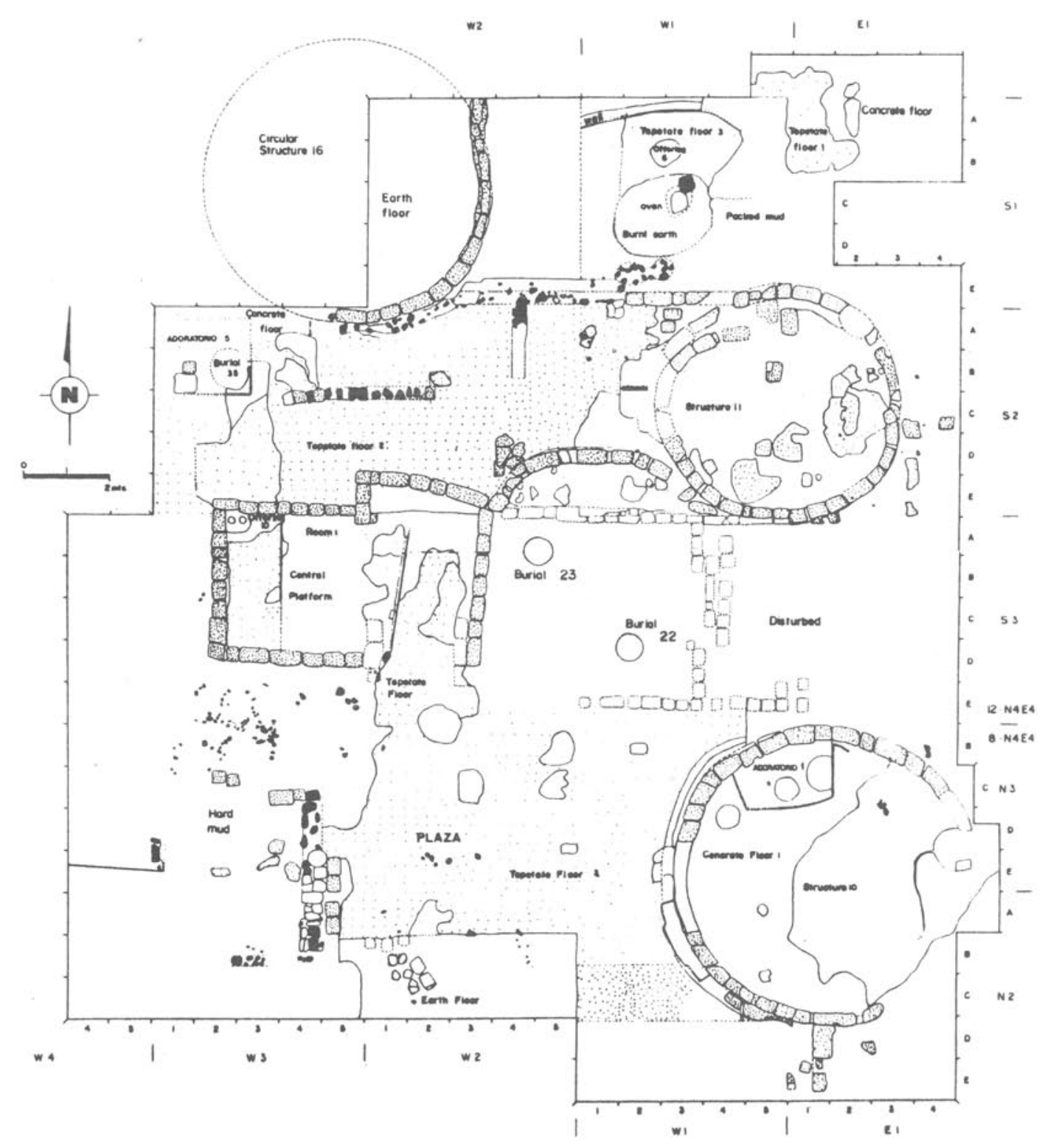

Figure 16: Plan of Mezquitla, Merchants' Barrio. Two burial pits (Burials 20-21) in Adoratorio 4 inside Circular Structure 10 had been emptied and resealed. Burial 22, located in the patio between Circular Structures 10 and 11, was associated with a rich offering including two Maya Polychrome vessels. Burial 23, also located in the patio, was associated with a stone polisher and a Thin Orange bowl. 


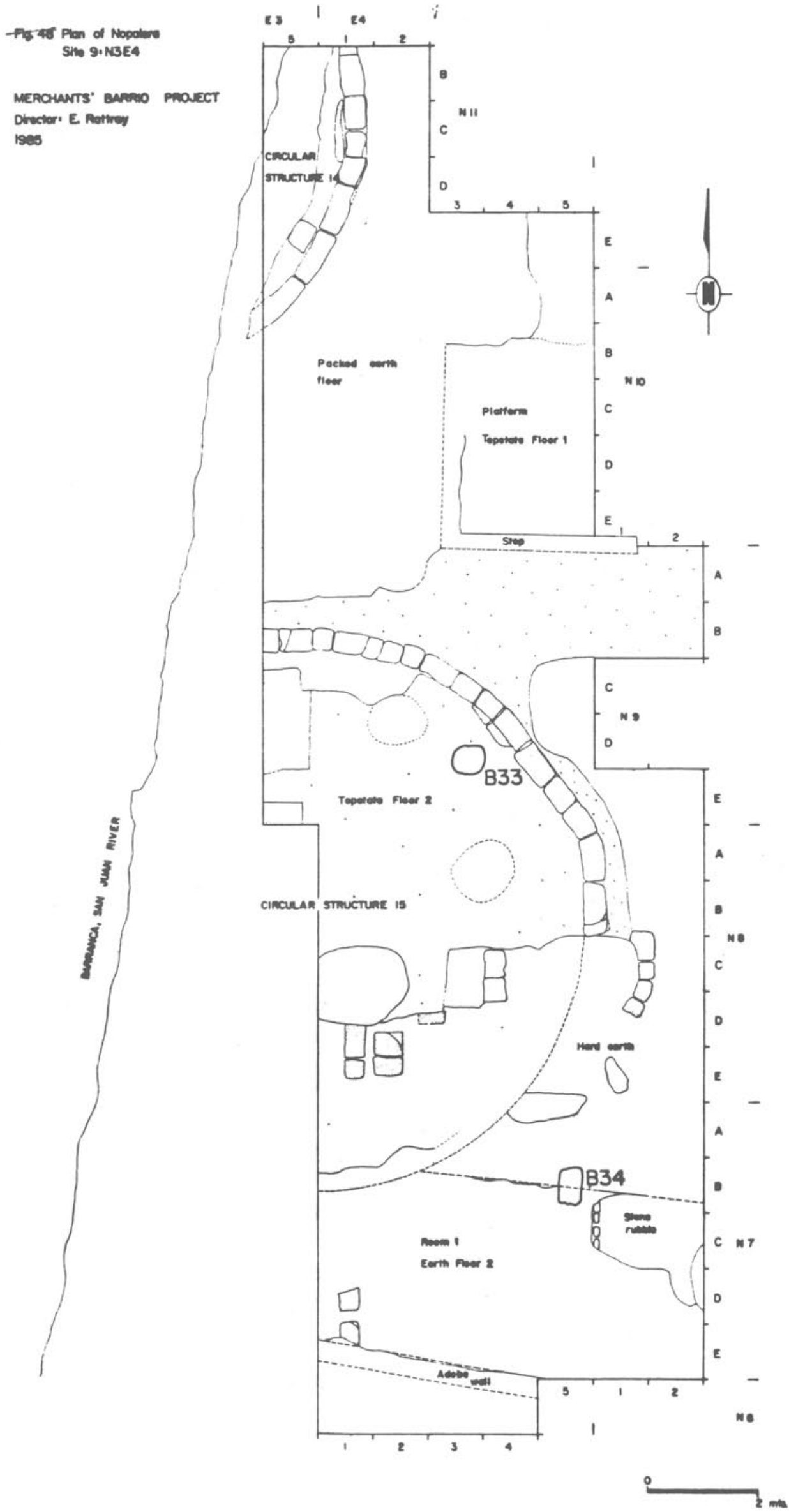

Figure 17: Plan of the Nopalera site, located on the opposite side of the barranca from Xocotitla, had two large Circular Structures (14 and 15) and associated Burials 33 and 34. 


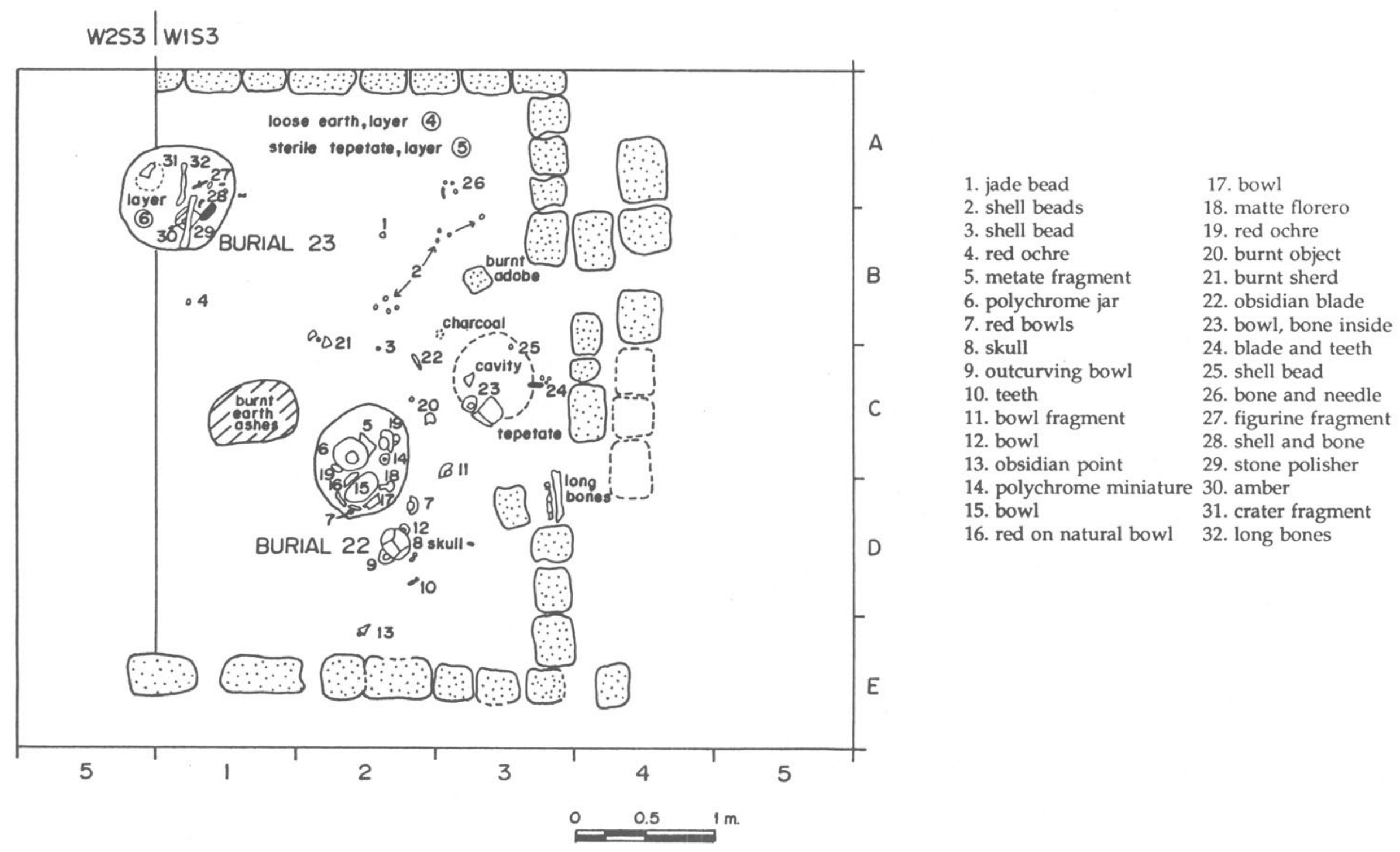

Figure 18: Plan of Late Tlamimolpa Phase Burials 22 and 23 and Offering, Merchants' Barrio, Site 12:N4E4, Square W1S3. 

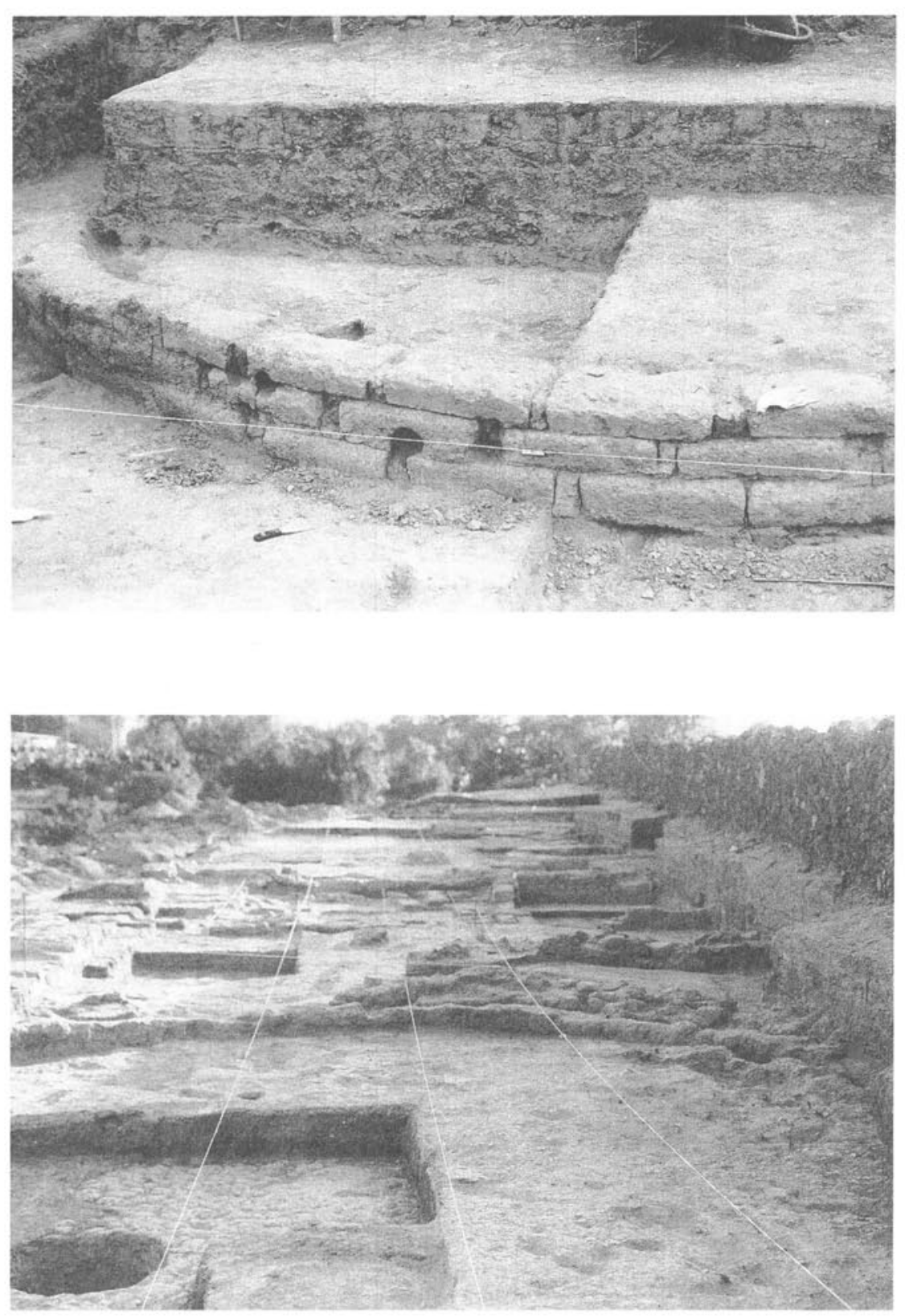

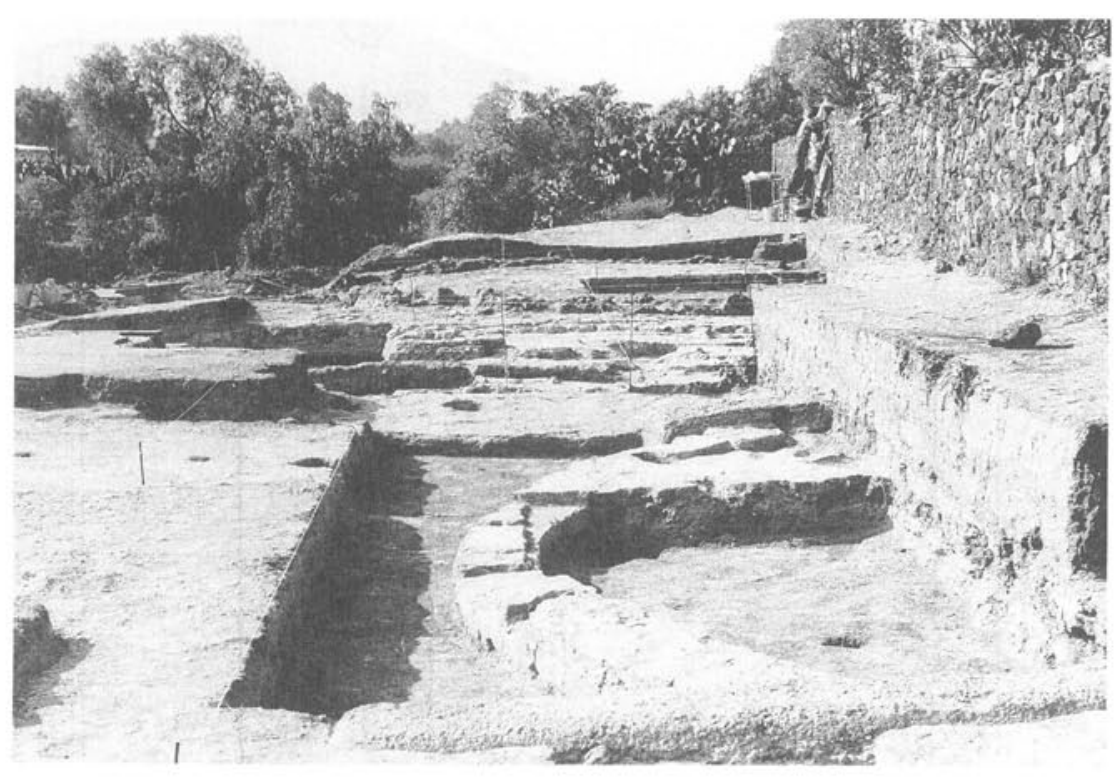

Plate XVI: Early Xolalpan Phase Round Houses exposed at Xocotitla, the Merchants' Barrio, Teotihuacan: a. East side of Circular Structure 1 showing adobe construction and superimposed floors on the inside of the cemetery wall; b. Circular Structure 2 in foreground with Burial 4 Pit exposed. Circular Structures 1 and 3 are located further south; c. Detail of Circular Structure 1 exposed on the west side of the cemetery wall below a concrete paving that had been built over it. 


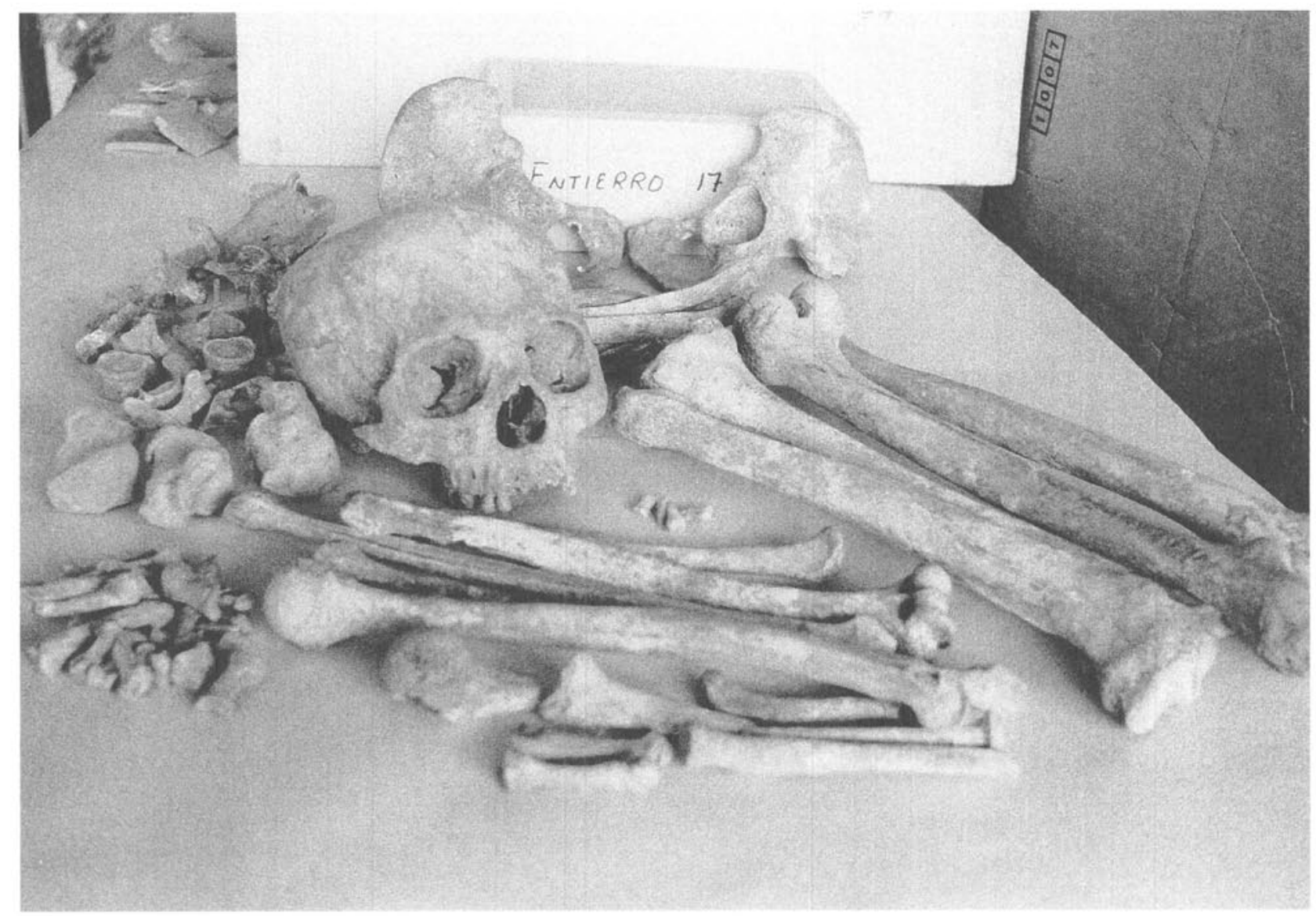

Plate XVII: Late Xolalpan Burial 17, Xocotitla. Bones of adult female recovered from Adoratorio 2 with marked tabular oblique cranial deformation. 


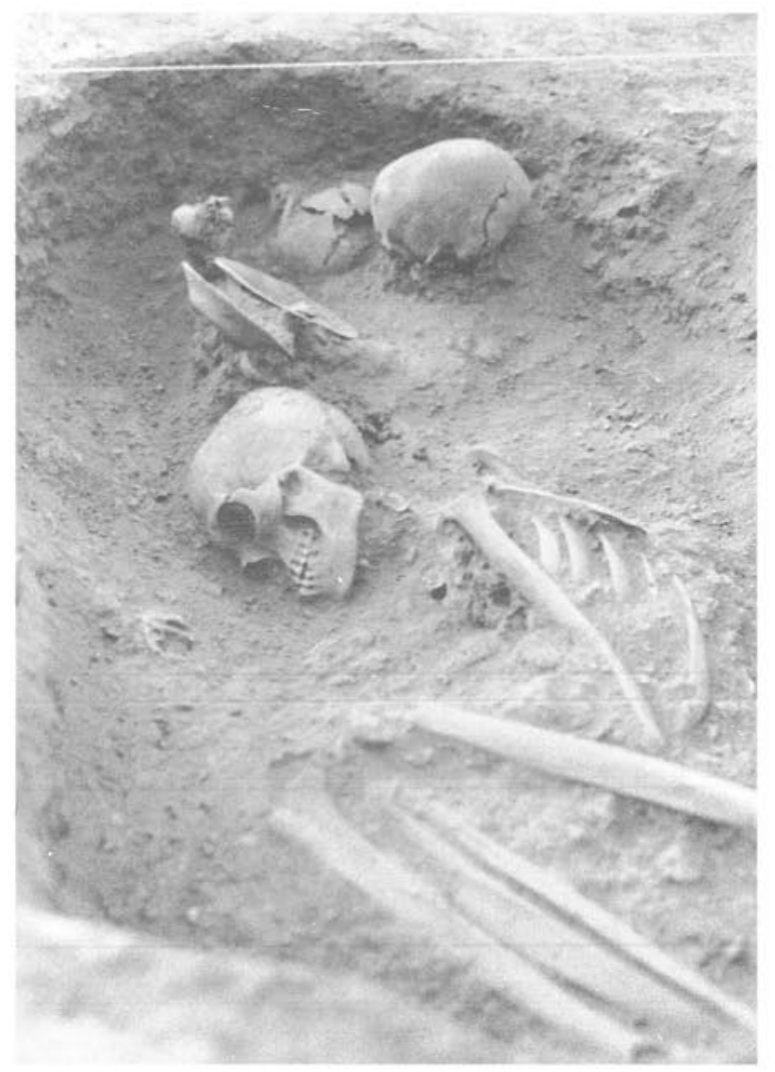

Plate XVIII: Late Xolalpan Burial 10-12, Circular Structure 4, Xocotitla. Bones of a young male in a shallow grave accompanied by bones of two adults, two children, and a fetus. The clay vessel offering consisted of two Polished outcurving bowls and two Copa ware vases. 


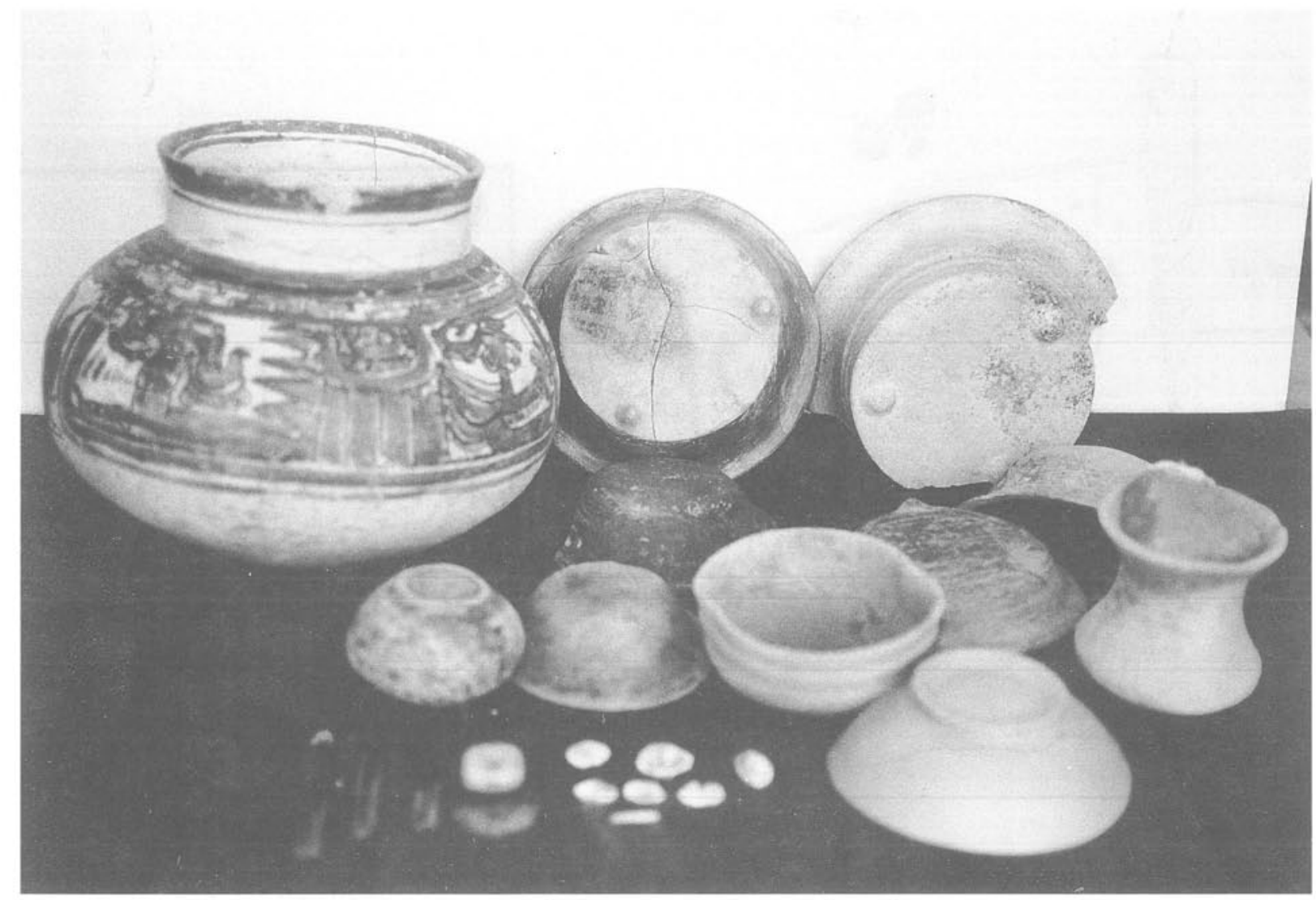

Plate XIX: Offering from Late Tlamimilolpa Phase Burial 22, Mezquitla. Top: Maya Polychrome jar, Red-on-Natural outcurving bowl. Below: miniature Maya Polychrome tecomate, recurved bowl, Dense ware corrugated bowl, Thin Orange bowl, compound silhouette jar, and shell beads. 


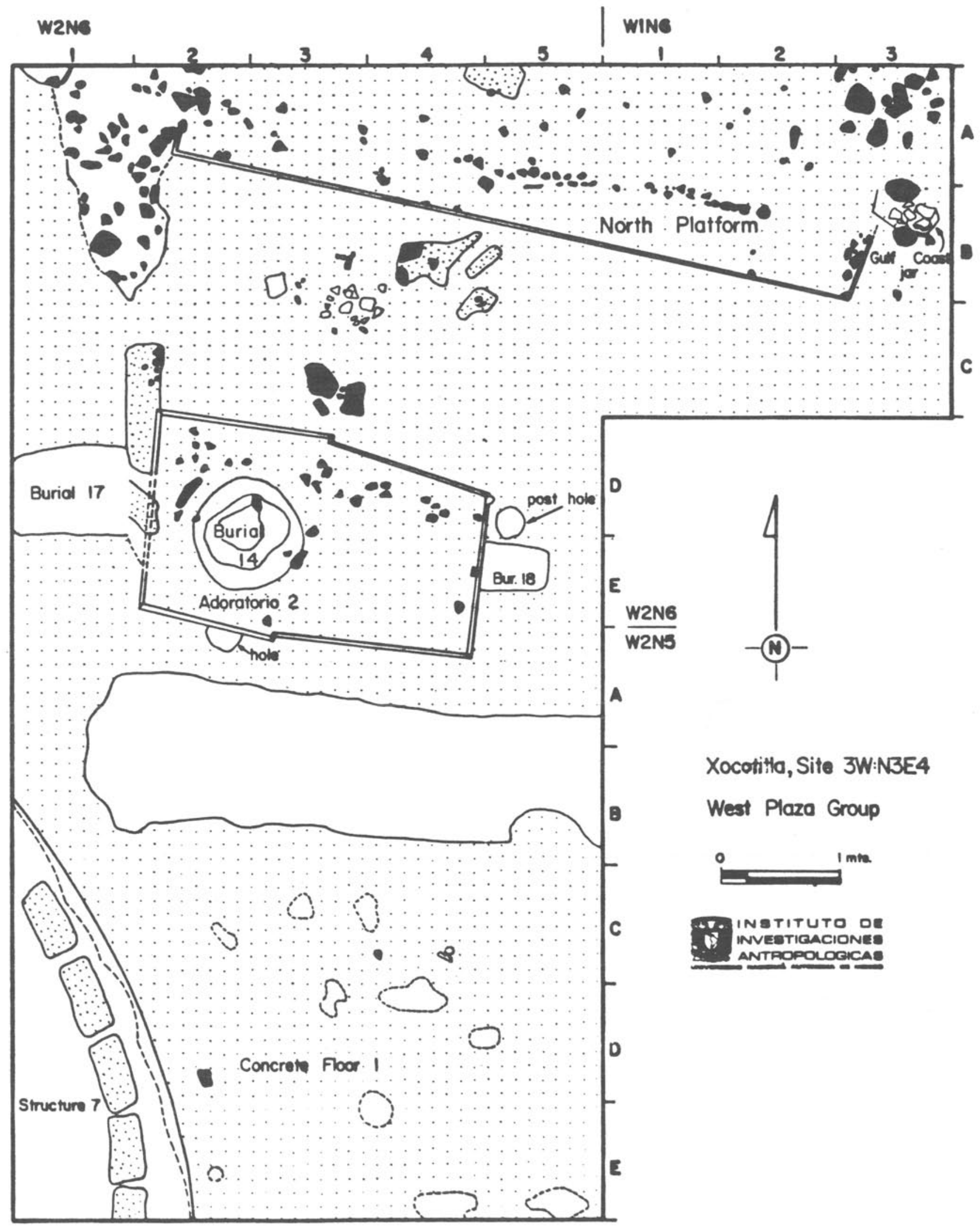

Figure 19: Plan of Adoratorio 2 with associated Burials 14, 17, and 18, Xocotitla, West Plaza Group, Site 3W:N3E4 


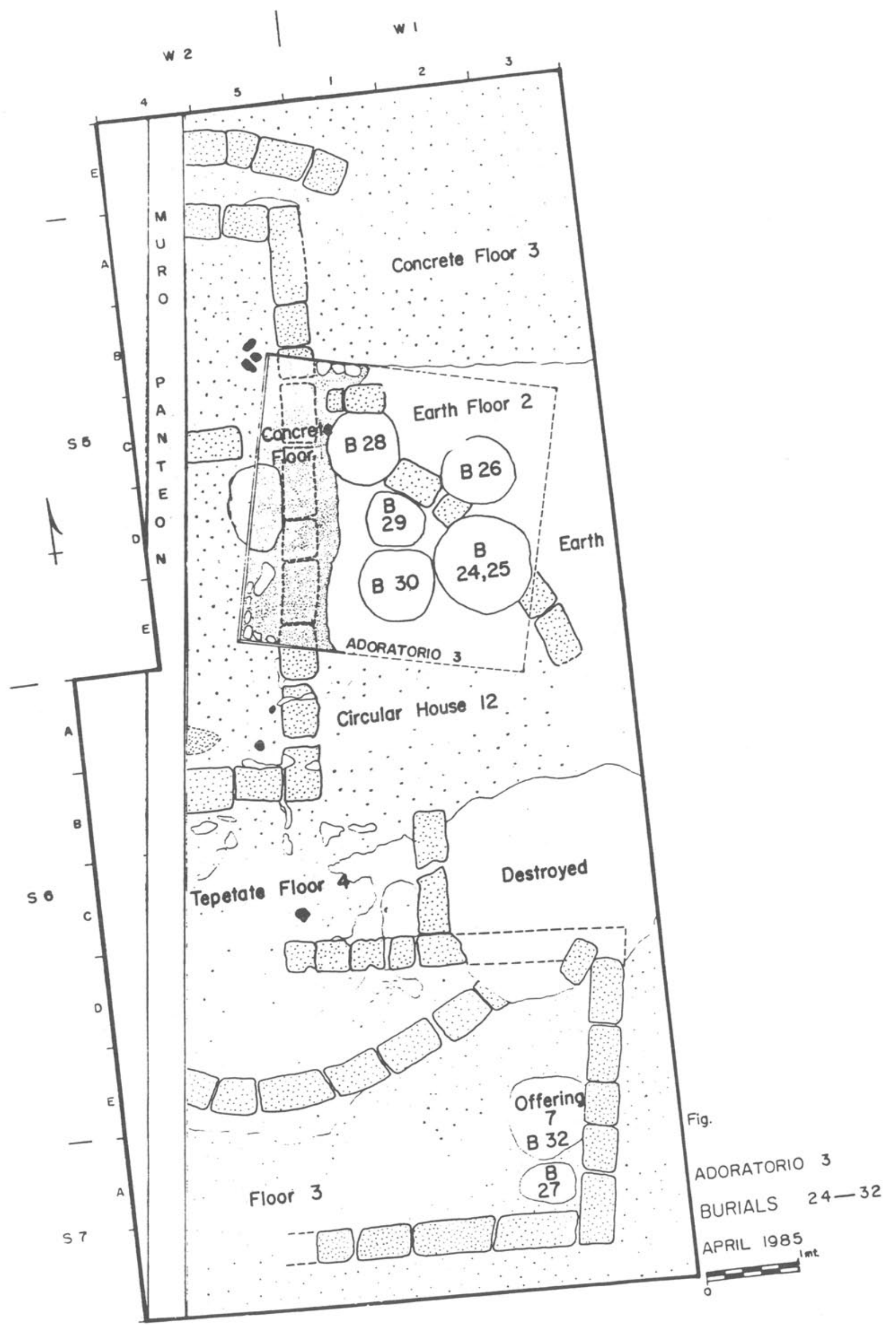




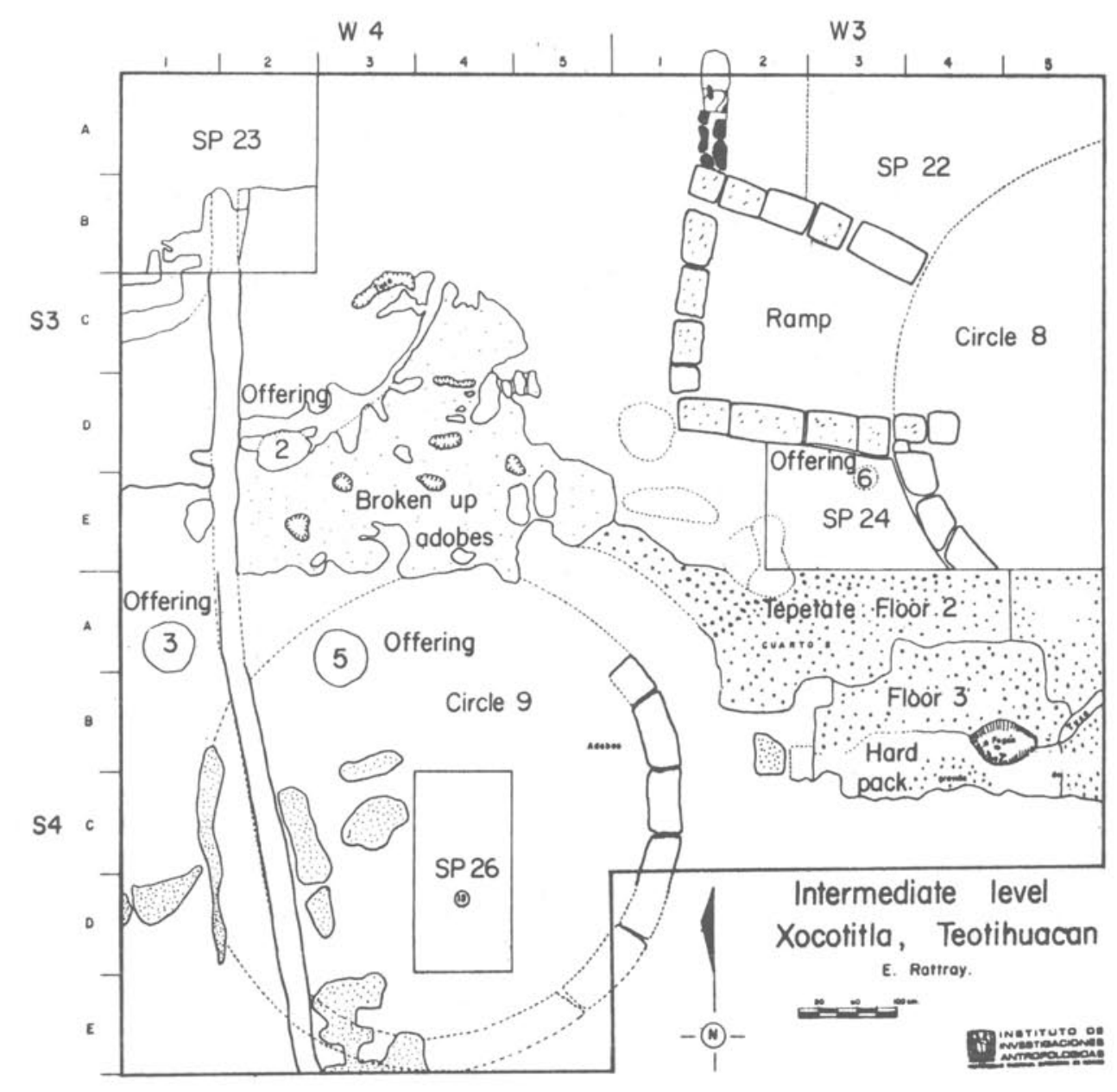

Figure 21: Intermediate level at Xocotitla where Incensario Offerings 2, 3, and 5 were recovered. Next to Circular Structure 8 was Offering 6 containing two Thin Orange bowls. 


\section{THE MERCHANTS' BARRIO}

This barrio is located on the extreme northeastern edge of Teotihuacan (fig. 1). Its architecture, planning and ceramic complex contrast strongly with all other known districts of Teotihuacan (fig. 15, 16, 17). The dominant form of architecture here consists of round houses with adobe walls (Plate XVI $a, b$, c) and presumably, roofs of perishable materials. From 1983 to 1985 in three field seasons, the Merchants' Barrio Project (Rattray 1987a, 1989) excavated 18 of these circular structures ranging in size from $5 \mathrm{~m}$ to $9.5 \mathrm{~m}$ in diameter, distributed along both sides of the ravine of the Río San Juan (fig. 1). The typical layout at the barrio consists of the plaza (approximately $10 \mathrm{~m}$ by $12 \mathrm{~m}$ ) surrounded by circular structures, sometimes alternating with rectangular platforms surmounted by rectangular rooms. Four of the plazas had small T-shaped shrines in the center, underneath which were multiple burials in circular pits. Circular Structure 4 stands out from the rest by virtue of its superior construction (concrete and stone) and large size ( $9.5 \mathrm{~m}$ in diameter) and may have served as the center for religious and secular barrio activities. The Late Xolalpan burials were located either below the floors or in a deep shaft tomb within the confines of this circular construction. The plazas located to the north, south and east also contained burial pits at one time or another.

Although Mezquititla (fig. 16) is separated from Tlamimilolpa by a street only, the two differ enormously. The Merchants' Barrio seems to have spread along the San Juan river southward to Xocotitla (fig. 15) and Nopalera (fig. 17), starting from a nucleus of round houses at Mezquititla where the earliest burials occurred (fig. 18, Plate XIX). Two almost identical structures were recently discovered by INAH archaeologist Rodríguez (1982: 55-73, Plans 1, 4) further down the river at the Great Rectangle that borders on the Ciudadela. This is a large open plaza with three small temples, evidently a non-residential section of the city, that was used for ceremonies and various kinds of craft working. The late occupants were artisans devoted to manufacturing elaborate ceremonial censers and figurines, and possibly were featherworking for the elite (Muñera 1985). Rodriguez interprets the "semi-circular" structures as "burial platforms" and "not as habitations of any kind". Late Tlamimilolpa-Early Xolalpan burials were located below the floors (Cabrera, personal communication 1988) and perhaps they did function as religious shrines and storage places for the pooling and redistribution of elite goods from the Gulf Coast and Maya regions.

Dating from the Tlamimilolpa phase, the standard Teotihuacan living quarters consist of suites in one-storey buildings measuring on an average $60 \mathrm{~m}$ by $60 \mathrm{~m}$ as at Tetitla, Zacuala and Atetelco (Séjourné 1966a, 1966c). The Tlamimilolpa compound just to the north of the Merchants' Barrio has clearly defined units, an organized grid arrangement, and an occasional temple with talud-tablero facade (Linné 1942, Rattray 1989). Xocotitla (fig. 15) lacks such units. Nevertheless there is evidence of central planning as the round houses are consistently located at approximately the same distances from one another and are grouped symmetrically around plazas.

We can glean some information on religious and cult behavior from the burial practices of the Merchants' Barrio peoples (Plates XVII, XVIII, XIX; figs. 18-21). Burials were customarily multiple and secondary, usually under the floors of the circular houses or associated with a shrine. The reconstruction of the burial customs of the population at the Merchants' Barrio is based on an analysis of the religious paraphernalia found throughout the barrio and the offerings accompanying the interments. The osteological characteristics of the eighty or more identifiable individuals from Xolotitla were studied by Civera (1989) who has provided the following data on the demographic makeup of the population. Family groups are represented by 80 individuals ( 24 males, 23 females and 33 of undetermined sex). One possibly unusual finding is the poor representation of individuals between the ages of 13 and 20 years. We might speculate that this age group had left the barrio to seek work elsewhere; that they may have been traders or carriers who journeyed to the distant lands of the Gulf Coast and died outside the barrio; or simply that this age group may not have been considered important enough to be given formal burial.

Cranial deformation is fairly common in Mesoamerica, occurring occasionally at Teotihuacan. Five 
of the six complete skulls from the Merchants' Barrio showed intentional cranial deformation (either tabular erect or tabular oblique) (Plate XVII). Deformation has been reported at La Ventilla B (Serrano and Lagunas 1975: Table 8), a barrio that also has Gulf Coast affiliations (Piña Chan 1963).

The individuals buried next to Adoratorio 2 (Burial 17, fig. 19, Plate XVII) and the infant in Burial 18 were interred sometime after Burial 14 (which had in it one male, one female, one child and one fetus) indicating continued usage of this shrine probably by members of the same family. The interments below Circular Structure 12 and Shrine 3 (fig. 20), Burials 24 to 30, are Early Xolalpan phase and were deposited there or moved there after the building of the Circular Structure and prior to that of Adoratorio B. Burials 27 and 32 also date to the same phase and were placed in the Patio area which was subsequently paved.

The burial offerings at the Merchants' Barrio are unlike most Teotihuacan burials for the large proportion of multiple and secondary interments. For example, thirty-one individuals were buried together in a very large pit within the ramp of Circular Structure 2, and eleven individuals in Circular Structure 12 (fig. 20); seven individuals were buried together in Circular Structure 4, in addition to two individuals from a deep shaft tomb made in Early Xolalpan times (Rattray 1987b).

The Gulf Coast group that settled on the northeastern fringes of Teotihuacan between 300 and 500 A.D. ${ }^{10}$ probably had origins in the Huaxteca region of Veracruz, as during that period Southern Veracruz traits (portable objects mainly) became abundant and dominant. Interestingly, at San Antonio Nogalar (Stresser Pean 1977: figs. 16, 17, 23, 30,32) the six burials recovered were placed under the floors of the circular houses or under the doorsteps.

Because of its peripheral location, its moderate size covering approximately $40,000 \mathrm{~m}^{2}$, and modest architecture, we have concluded that the status level represented at the Merchants' Barrio was non-elite. The inhabitants may have been a group of traders (pochteca) or carriers (tlamemes), hereditary groups that may have originated in the Veracruz region (Acosta Saignes 1945), as this barrio seems definitely to be linked with the procurement of exotic goods. More jade has been found here than from the lapidary workshops of Teotihuacan, although the size of the excavation may have been a factor. There are also foreign imports such as fine ceramic vessels, honey-brown chert from Belize (Iceland 1989) and amber, probably from Chiapas. Some evidence for Maya coexisting with Gulf Coast individuals comes from the Mezquititla, Late Tlamimilolpa Burials 22a and 22b where a young adult and child were buried together with rich offerings including two Maya polychrome vessels, four Thin Orange bowls, jade and amber (fig. 18, Plate XIX). An unusual aspect of the burial was the presence of a fired area, a possible pyre. Maya basal flange bowls occur throughout the Merchants' Barrio, although less frequently than the Gulf Coast types ${ }^{11}$. Early Xolalpan Burial 32 (a middle-aged male) at Xocotitla (fig. 15) contained a Maya Orange Gloss compound silhouette jar and shell objects. Burials 13a and $13 \mathrm{~b}$ were accompanied by sherds of two Maya polychrome bowls that had been smashed by looters, a stucco Painted vase, and shell. This large boot-shaped shaft tomb attests to the wealth bestowed postmortem on the female and fetus interred here.

The persistent spatial association of foreign goods with round houses and family shrines symbolically represents the ethnic unity and cohesiveness of the Merchants' Barrio. There seems to be no doubt that this was a foreign enclave of peoples from the Gulf Coast (probably Huaxtecan and Southern Gulf Coast peoples). The Gulf Coast Huaxteca region is unique in Mesoamerica in that entire settlements there were composed of circular habitations, exemplified by San Antonio Nogalar (Stresser Pean 1977: fold-out map).

That ethnicity and consequent alliances were the principal determinants for the maintenance of the Merchants' Barrio in Teotihuacan for some 300 years cannot be doubted. That families were permanent residents is evident from the burials, the houses, and the culinary and religious customs (Rattray 1990). 
To continue the discussion of Early Classic mortuary customs, Late Tlamimilolpa burials have not survived very well, our inventory showing three at Tlamimilolpa, three at Tetitla, and three at Yayahuala. They share elements such as Thin Orange vessels; Polished black gadrooned and plain jars and bowls; and Painted Red on Natural outcurving bowls and vases. Early Xolalpan burials are better represented, numbering three at Tlamimilolpa, two at Xolalpan, six at Tetitla, five at Zacuala and four at Yayahuala. Linné's $(1934,1942)$ report on the burials from the Xolalpan and Tlamimilolpa compounds gives us much concrete knowledge on how the Teotihuacanos buried their dead, although the number of burials reported was small and not truly representative of the population that inhabited these compounds over a period of time. A possible explanation for the situation at Tlamimilolpa (fig. 22) is that Linné's excavations generally did not penetrate to the deepest level. Two exceptions occur: the first is an area encompassing $300^{\mathrm{m} 2}$ excavated to bedrock near the center of the compound where Linné reported 6 burials and 2 caches; and the deep excavation under Room 16 where Burial 1 was discovered. In all, Linné recovered thirteen burials: three Late Tlamimilolpa, three Early Xolalpan, two Late Xolalpan, one Metepec and four unphased burials. Burial 1, the earliest ${ }^{12}$ and most important because of the size of the offering (over 1200 artifacts), was discovered in a kind of tomb under the walls and floors of Room 16. It was constructed of adobe, and its roof coincided with the floor of the room above (Linné 1942: 125, figs. 185, 186). The walls utilized for the tomb construction belonged to an earlier construction phase that was built onto to form a chamber, the interior filled with:

...whole or broken clay vessels and other artifacts, considerable quantities of charcoal, shells, and some few skeletal fragments. This was covered by a layer of closely packed charcoal. Between this and the roof there was a layer of yellowish substance, some $2 \mathrm{~cm}$. in thickness...The body had been cremated in the grave itself. (Linné 1942: 126)

Cremation is not a common practice at Teotihuacan. Contexts in which it occurs suggest exclusive treatment of high status personages of which there are only one or two to a compound. Partial cremation occurs as in Burial 1-'83, Room 56 (figs. 23, 24). The individual in Adoratorio 1 at Xocotitla (a very prestigious location) received such treatment.

Sacrificial burials of various phases throughout Teotihuacan's existence have been reported sporadically. A sacrificial burial of four decapitated individuals ( 2 males, 2 females) occurred in the zone west of the Great Rectangle, dated to the Late Tlamimilolpa phase (Gonzalez and Salas 1990: 168, fig. 7). An extraordinary find was that of archaeologist Enrique Martínez in a place called Solar Amanalco in the Barrio of San Francisco Mazapan, Teotihuacan (Site 25: N3E3), located some 400 meters southeast of the Barrio de los Comerciantes. A square "funerary structure", measuring $1.74 \mathrm{~m}$ on a side and $.80 \mathrm{~m}$ high, was excavated, revealing the cremation of a male individual. Surrounding the central figure were five decapitated males, sacrificial victims according to Martinez and Gonzalez (1983). The ceremony has been dated to the Early Xolalpan phase based on vessel style and radiocarbon dates, and seemed to show Gulf Coast traits.

Subsequent excavations by Rattray $(1983,1987 \mathrm{~b})$ adjacent to the $300 \mathrm{~m}^{2}$ where Linné had recovered over half of the burials yielded an additional 2 Early Xolalpan adults and 3 infants. The infant burials appear to have been dedications made when the new building level was constructed (fig. 23). A comparison between the Tlamimilolpa compound and the Merchants' Barrio throughout the Late Tlamimilolpa and Xolalpan phases shows that they differed drastically in architecture. The Merchants' Barrio is a unique neighborhood of circular houses constructed mainly of adobe bricks with clay and concrete-tepetate floors, whereas Tlamimilolpa is constructed in the typical Teotihuacan architectural style with masonry walls and good concrete floors. In the last phase of occupation at the Merchants' Barrio, a rectangular adobe house was erected over the circular structures. Tlamimilolpa was also modified many times throughout its existence by vertical and lateral accretion. 


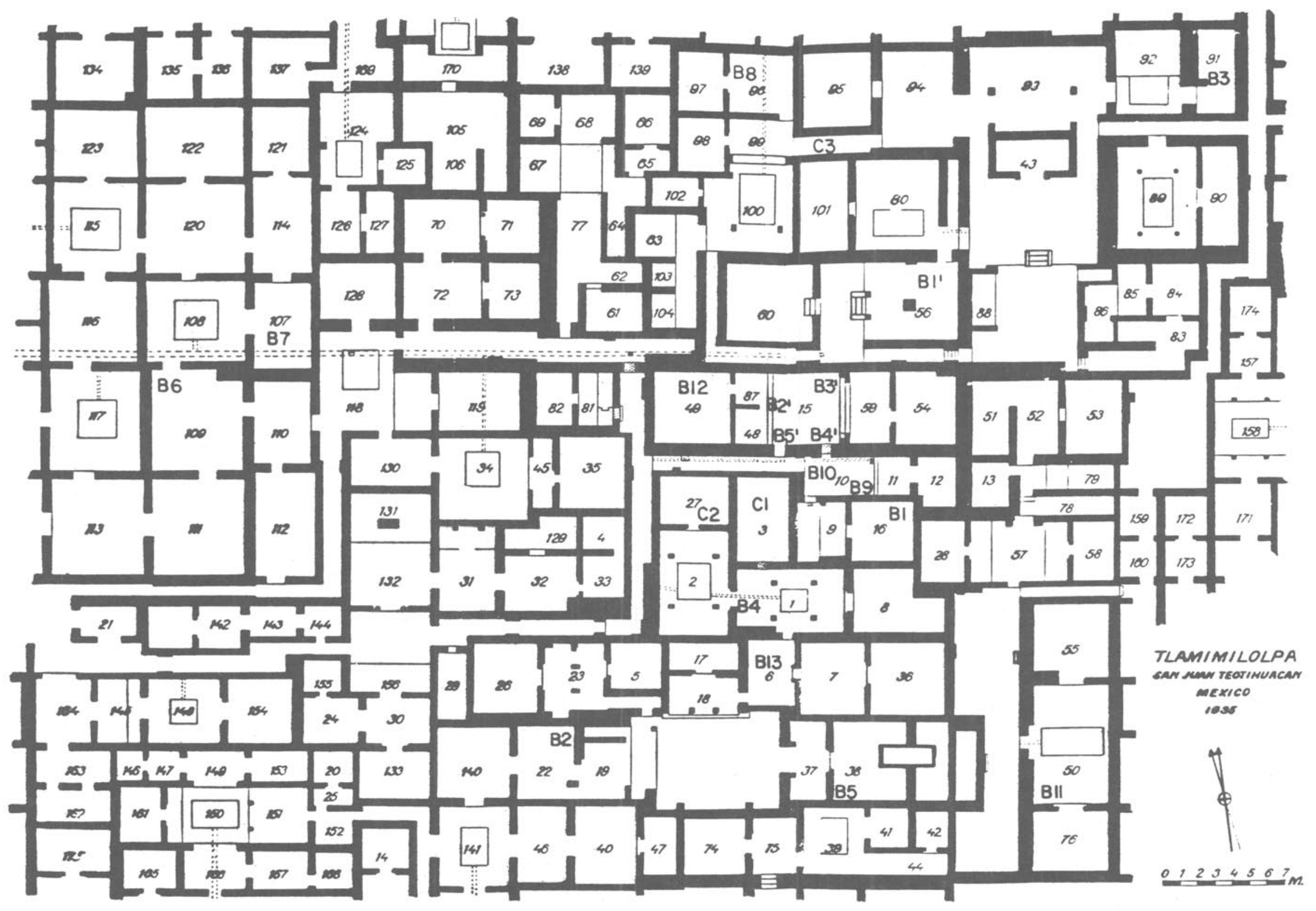

Figure 22: Plan of the Tlamimilolpa Compound with burial locations indicated (from Linne 1946, Figure 1). 


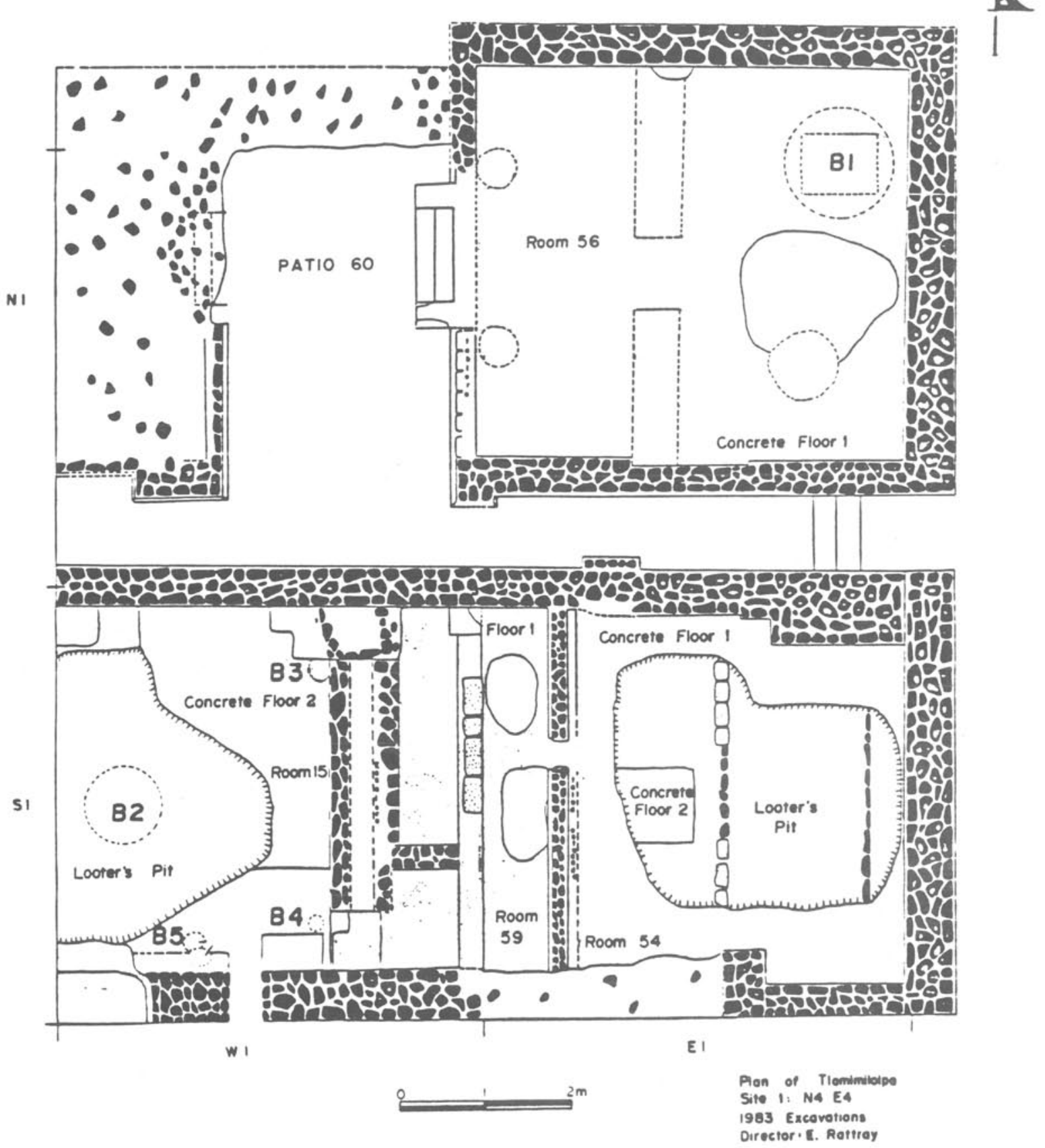

Figure 23: Plan of Rooms 60,56, 15, 59, and 54 at the Tlamilolpa Compound excavated by Rattray in 1983. Burial 1 in Room 56 was sealed over with a square patch. Looted Burial 2 and the infant dedicatory Burials B3, B4, and B5 were located in Room 15 (Rattray 1987). 


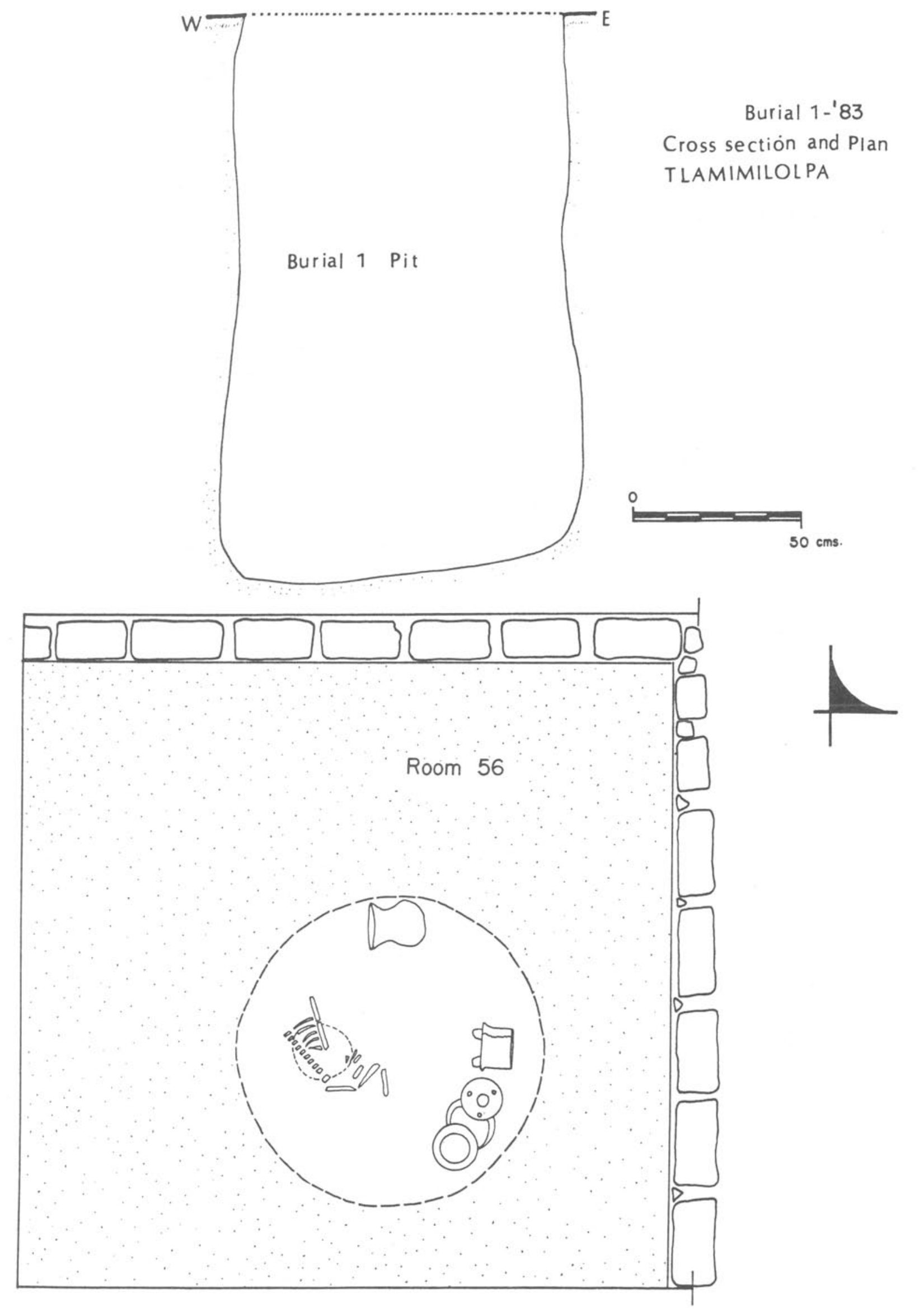

Figure 24: Plan and Profile of Burial 1-'83, Tlamilolpa Compound. The partially cremated adult male in Room 56 was accompanied by typical Teotihuacan vessels of the Early Xolalpan Phase. 


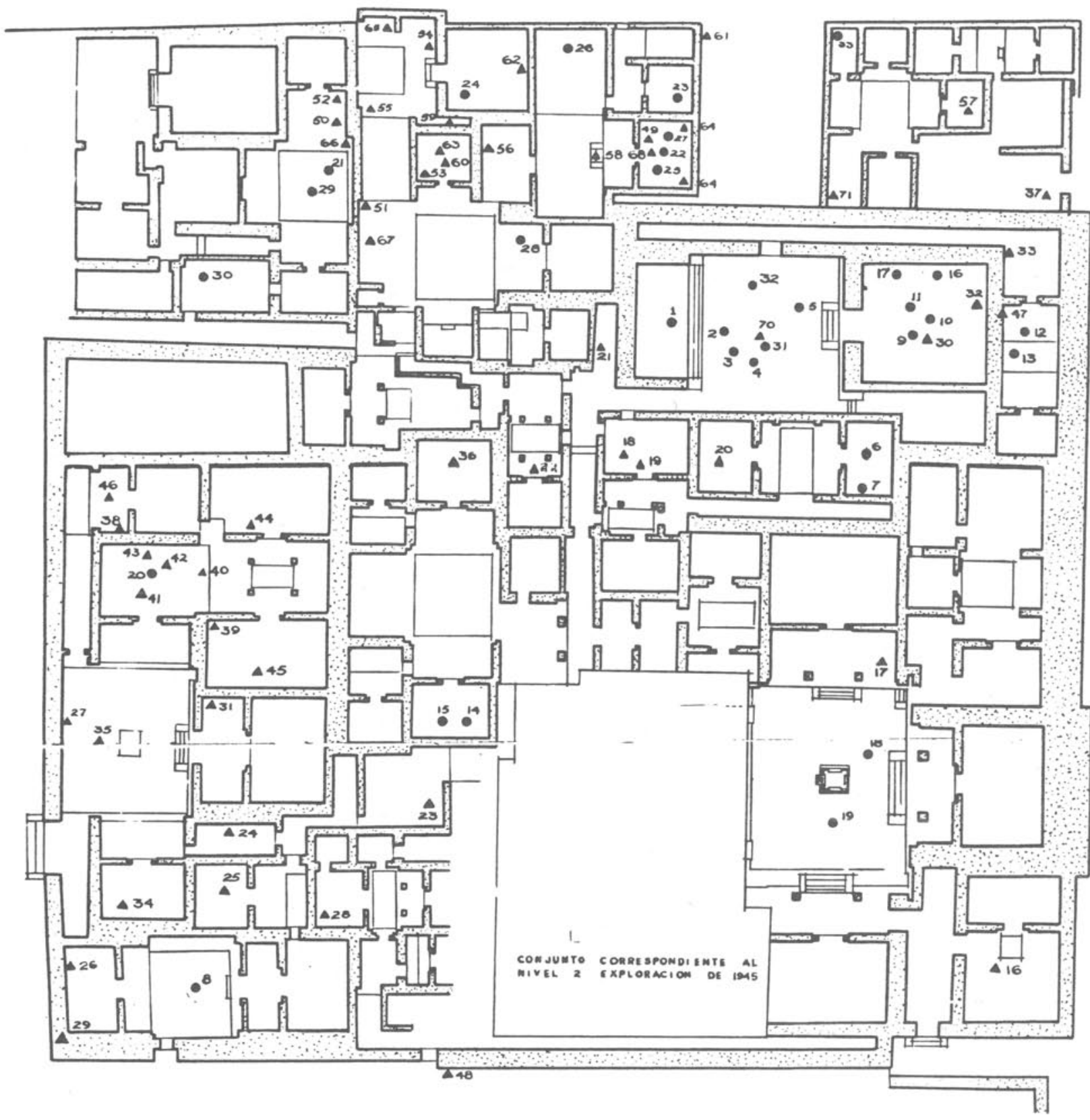

$\begin{array}{lllllll}\text { T } & \text { E } & \text { T } & \text { I } & \text { T } & \text { L } & \text { A }\end{array}$

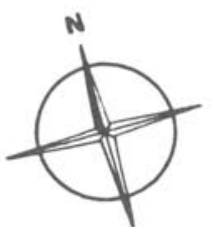

Fic. 220

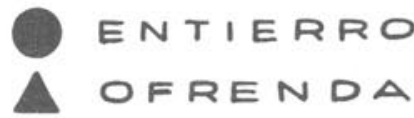

$\triangle O F R E N D$

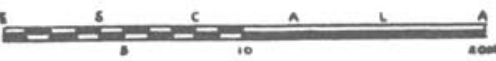

Figure 25: Plan of the Tetitla Compound showing the Burials and Offerings recovered from under the floors of the third level of construction (Sejourne 1966a, Figure 220). 


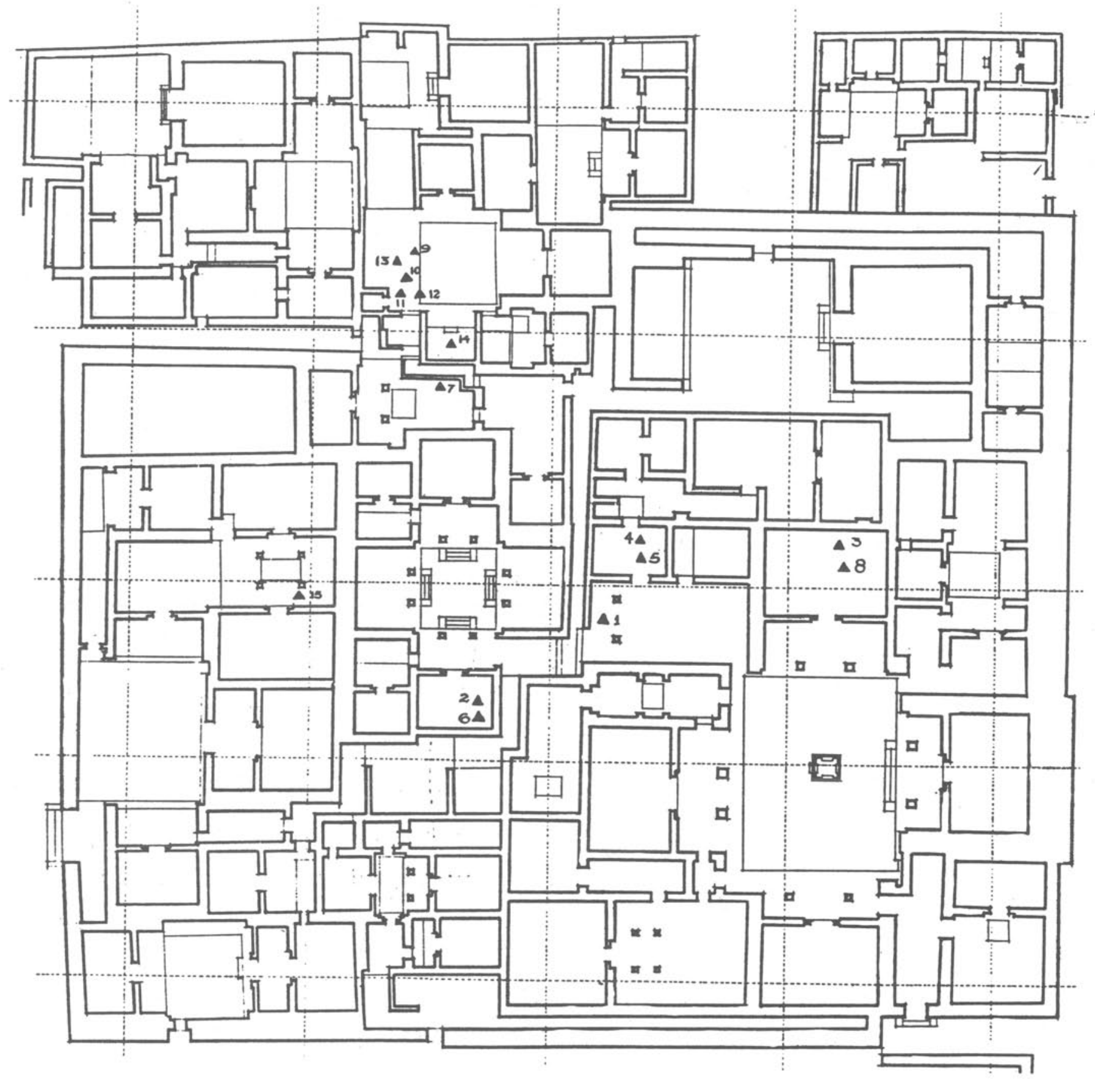

$\begin{array}{lllllll}\text { T } & E & T & \text { I } & \text { T } & \text { L } & \text { A }\end{array}$

ENTIERRO

- ofrenda

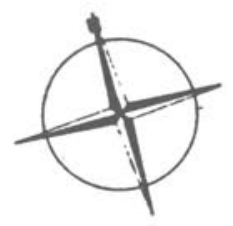

FIG. 221

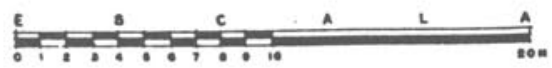

Figure 26: Plan of the Tetitla Compound showing the Burials and Offerings recovered from under the floors of the second level of construction (Sejourne 1966a, Figure 221) 


\section{THIN ORANGE IN TEOTIHUACAN BURIALS}

Beginning with the Late Tlamimilolpa phase at Teotihuacan, we find a significant number of burials accompanied by Thin Orange vessels in compounds all over the city, whether they manifest Teotihuacan traits or are of different ethnic affiliations. Characteristic forms are ringbase bowls (Plate VI), cylindrical tripods (Plate XXI) and effigies. La Ventilla B burials, Late Tlamimilolpa Burials 3, 37, 38 and 42, and Salvage Burial XI all contained Thin Orange vessels. They occur also in Early Xolalpan burials at Tetitla (Burials 27, 32), at La Ventilla A (13 vessels from several burials) and at La Ventilla B Burial 11, the latter a Thin Orange effigy. They are common in Late Xolalpan contexts at Tetitla such as Burials 9, $14,15,18$ and 28 , but diminish in later burials such as Burials 10, 30, and 33 . Burial 86 contained a Thin Orange dog (or coyote) covered with red paint.

Thin Orange is inextricably tied up with burial customs and religious rites. When it appears at sites great distances from Teotihuacan such as the Maya sites of Tikal and Kaminaljuyú, it is always considered as indicative of a Teotihuacan presence. For example, at Kaminaljuyú, Thin Orange was highly controlled and occurred only in Tombs A and B. In Tomb X, associated with Tomb B1, there was a beautiful effigy vessel with classic Teotihuacan features (Plate XXII) accompanied by rich offerings (Kidder, Jennings and Shook 1946).

The contexts of Thin Orange at Teotihuacan are varied: it occurs in burials, dedicatory offerings and in the rooms and fill of apartment compounds. Dedicatory offerings of one or two Thin Orange bowls are common, occurring at Tetitla (Moore 1966, fig. 6) and at the Merchants' Barrio (fig. 21). We now know that Thin Orange ceramics were manufactured in the Río Carnero region of Tepexi de Rodriguez, Puebla (Rattray 1990). The region had a flourishing civilization during the Classic Period (A.D. 300-750) which enjoyed continuous, intensive contacts with Teotihuacan, yet the region appears not to have been under the domination of the Teotihuacan state.

\section{THE LATE CLASSIC PERIOD BURIALS: LATE XOLALPAN-METEPEC PHASES}

An enormous amount of wealth was poured into the Late Xolalpan burials in compounds all over Teotihuacan. (A typical multiple burial with a double burial pit is illustrated in Plate XXIII). This contrasts with a definite decline in the number and lavishness of the Metepec phase burials ${ }^{13}$. No clear pattern can be discerned for this period. Many themes (ethnicity, the coexistence of religious cults, sacrificial burials) continue from earlier times. Offerings are richer and furnished with elaborate vessels and incensarios (Plate XX). Copa Ware was introduced in the Early Xolalpan phase and became an important mortuary accompaniment. At Tetitla, for example, Burials 4, 26 and 32 contained Copa ware; Burials 9, 14, 15, 18 and 28 contained stucco Painted vases, Thin Orange vessels, and sometimes Tlaloc jars. A prestigious location in the Tetitla Compound for burial ceremonies and dedicatory offerings seems to have been the Northeast Temple Complex (figs. 25, 26), as it continued to be a disposal area throughout the Xolalpan and Metepec phases. The major occupancy at Zacuala Patios (fig. 27) and Zacuala Palace (fig. 28) was during the Late Xolalpan-Metepec phases, as an analysis of the burials has demonstrated. Nearby Yayahuala (fig. 29) followed a similar sequence with an earlier occupation and unexplained paucity of Late Xolalpan burials and Metepec burials, although excavations (Millon 1973; Starbuck 1973) have shown that occupation continued there throughout the last two centuries of Teotihuacan's Classic period. We lack data on burials from three important excavated compounds on or near the Avenue of the Dead, the Palace of the Sun, Tepantitla, and the Viking Group. Except for the mention of a possible tomb at the Quetzalpapalotl Palace (Acosta 1964: Plan 4) we have no further information on the mortuary behavior of the individuals who occupied one of the most magnificent palaces of the Late Classic at Teotihuacan.

Important burials are known from the Tlamimilolpa and Xolalpan Compounds. Burial 13, an aged adult, at the Tlamimilolpa site was notable for the wealth displayed (onyx bowl, mother of pearl 


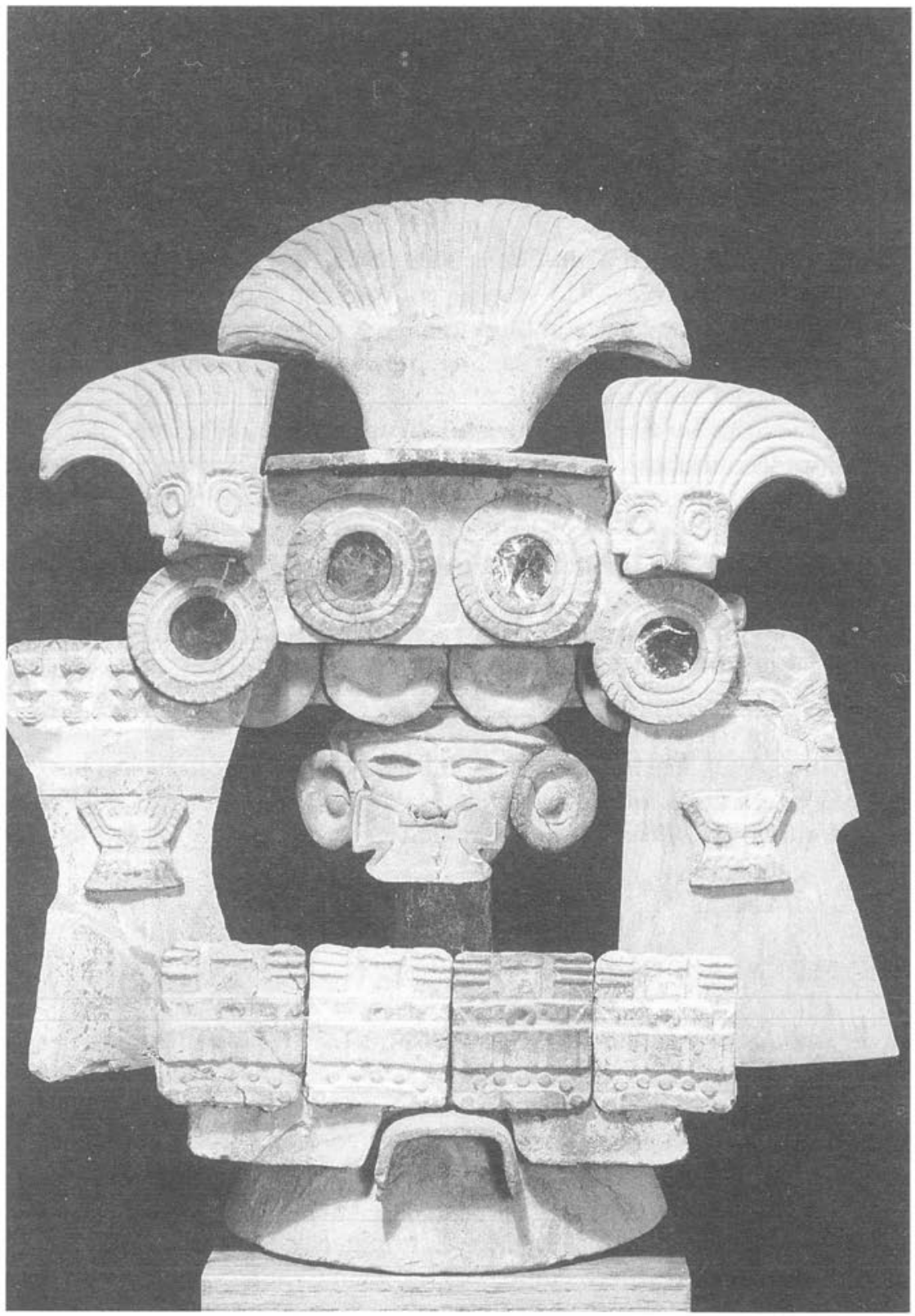

Plate XX: Late Xolalpan Incensario from Tetitla. Offering 29, consisting of a central face mask surrounded by molded clay adornos (birds, butterflies, feathered disks, flat plaques painted in brilliant colors) mounted on a large flat frame attached to the chimney. This fragile structure sits on a flower-pot shape vessel and conical base which are not shown. Photo by Reyes. 


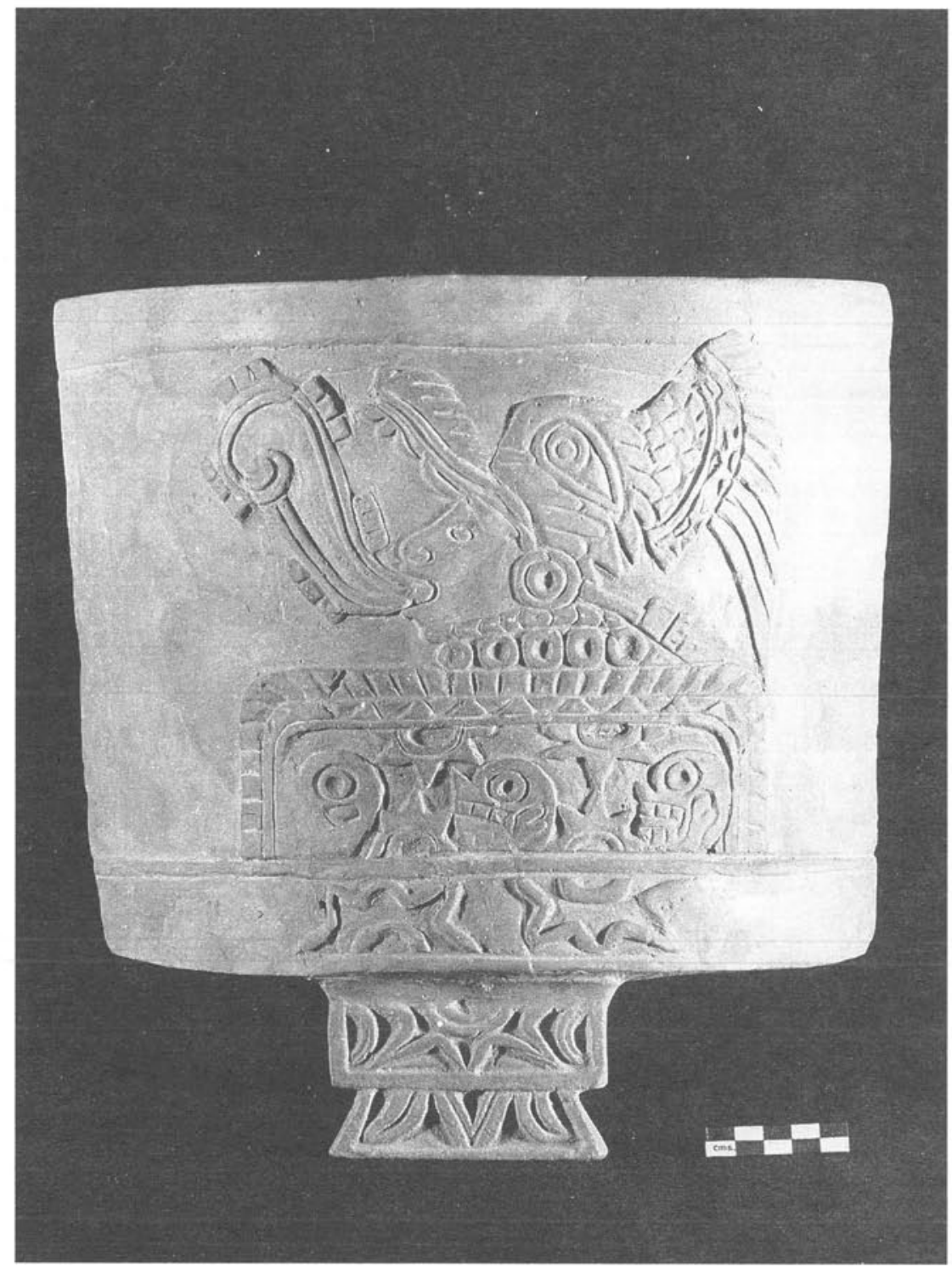

Plate XXI: Late Xolalpan or Metepec Phase Thin Orange cylindrical vase with moldmade applique in a complex iconographic style. Photo by Reyes. 

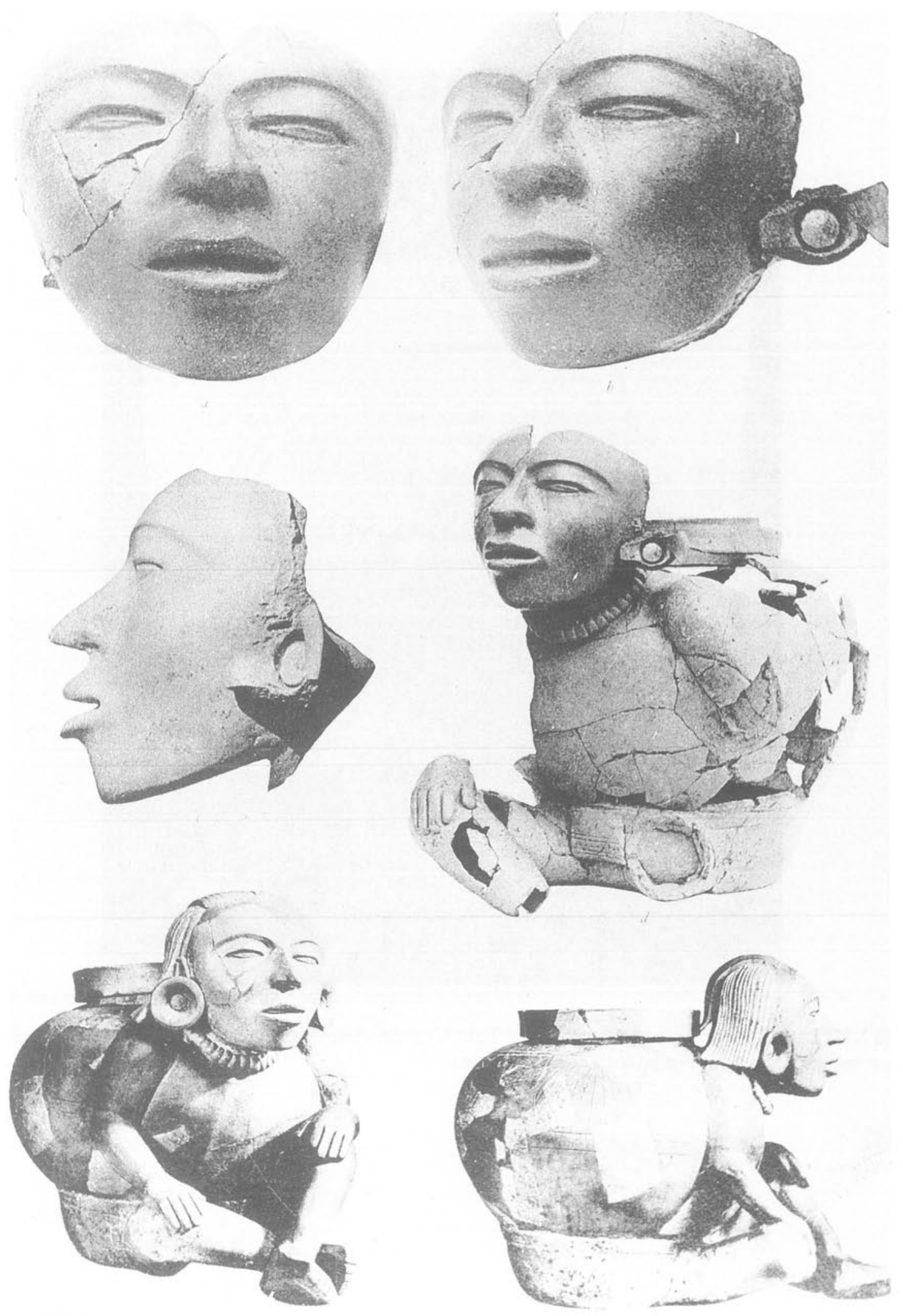

Plate XXII: Esperanza Phase Thin Orange effigy from Kaminaljuyu, Guatemala, Tomb X (associated with Tomb B1). Maximum diameter, $30.6 \mathrm{~cm}$. Reproduced from Kidder, Jennings, and Shook 1946, Figure 193. 


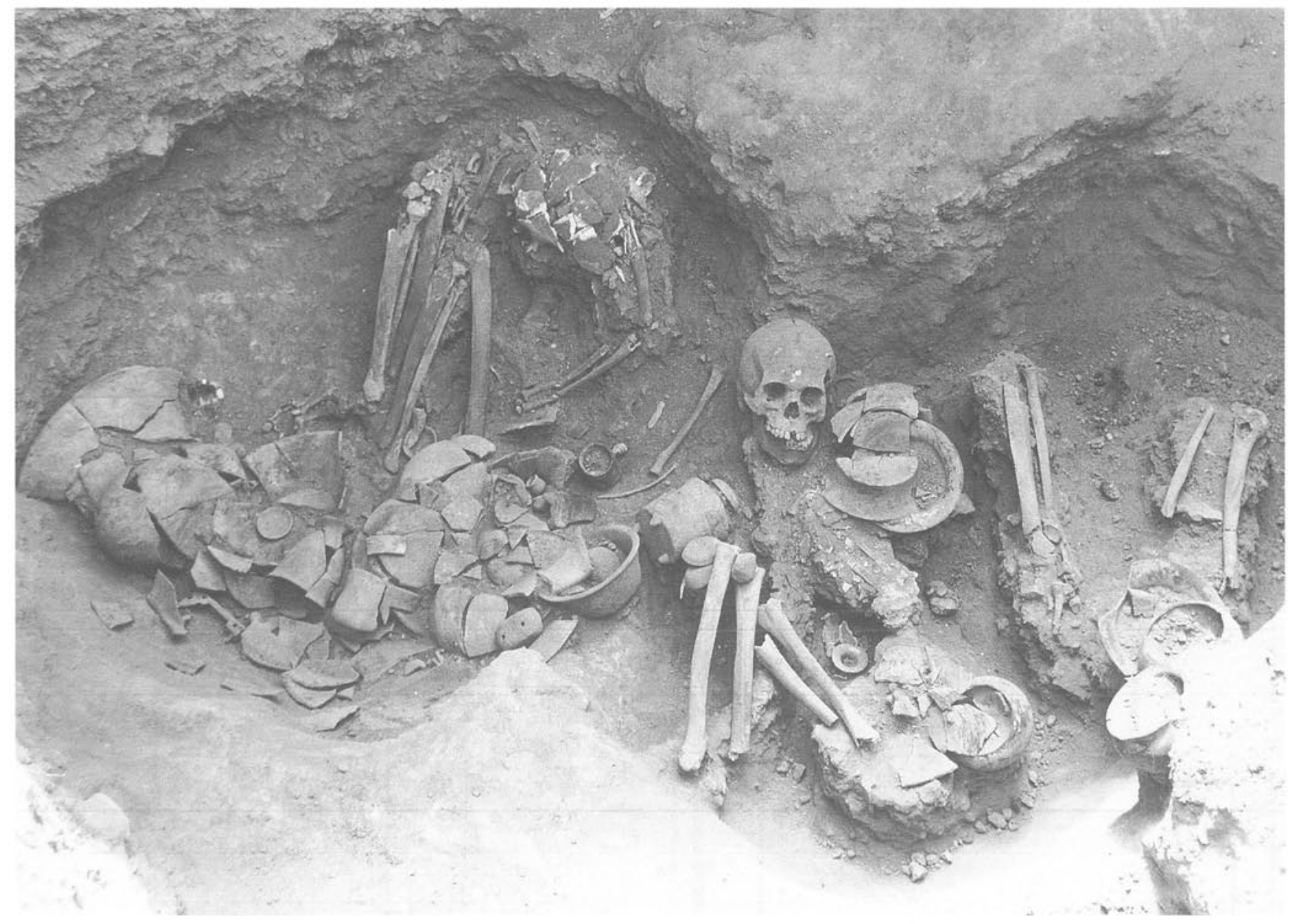

Plate XXIII: Late Xolalpan Phase multiple burial made in tepetate with large offering of clay vessels (outcurving bowls, recurved bowls, jars, cylindrical vases, Thin Orange bowls, Matte miniatures, etc.) From INAH Projecto Teotihuacan 80-82 excavations, supervised by R. Cabrera (from Cabrera 1987, Photo 8). 


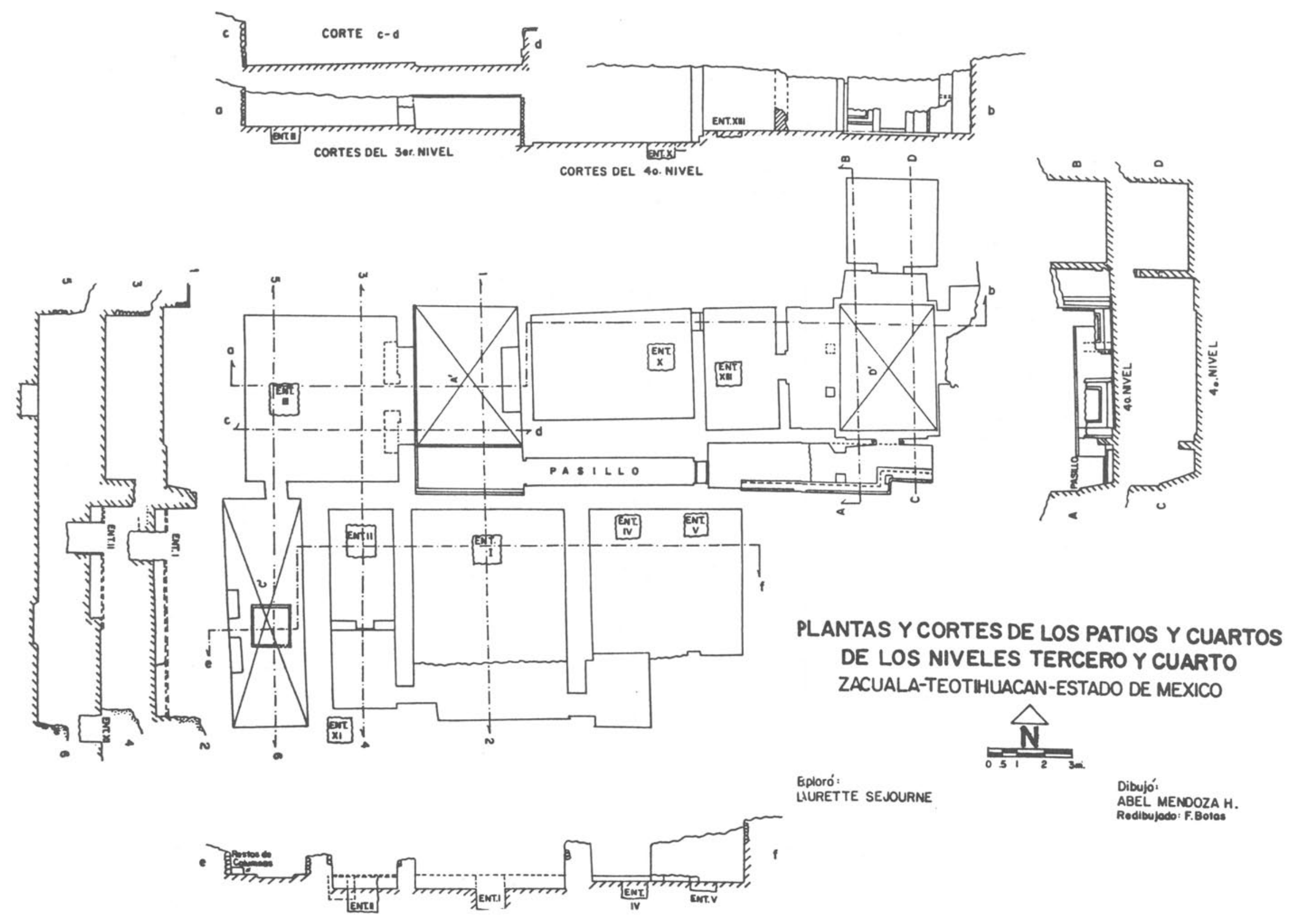

Figure 27: Plan of the Zacuala Patios and Rooms in the third and fourth levels of construction (Sejourne 1959, Figure 35). 
ornaments, rings of shell, jade beads, two identical stucco Painted cylindrical vases) (fig. 22, Linné 1942: fig. 272-273). Burial 4, an adult male, was favored with objects of personal adornment (earplugs) and an unusually fine collection of obsidian objects (a large lanceolate knife, $13.5 \mathrm{~cm}$ long, 2 projectile points, a scraper, blades and 2 obsidian figurines) (Linné 1942: figs. 263-271).

Burials 1 and 2 at the Xolalpan Compound (fig. 30) were stocked with incredibly beautiful Polished plano-relief vases, particularly those of Burials 1 and 2. The individual in Burial 1 was afforded unique treatment in being placed in a special tomb-like structure (Linné 1934: 60). Burial 2 contained a pair of cylindrical tripods in plano-relief designs that are iconographically Maya rather than Teotihuacan, in that they represent a "long-lipped" Maya god (ibid., figs. 28, 29). These occurrences point to an eliteoriented exchange of goods and ideas between Teotihuacan rulers and Maya nobility, particularly with the site of Tikal where Coggins (1976) finds overwhelming evidence of a Teotihuacan presence including cremation burial rites, Teotihuacan vases, green obsidian blades and the Tlaloc complex. Among the important burials at Tikal supporting contact are those of three presumed Central Mexican individuals from Problematical Deposits 50, 22 and 74 that were accompanied by exotic vessels. The figures on the vessel from Deposit 50 are Central Mexican, probably Teotihuacanos carrying offerings toward a temple. However, Ball (1983: 133) says that "the known actual occurrences of Mexican plateau pottery vessels or replicas thereof at Tikal are few in number and restricted in context to (a) the graves of prominent local elite-status individuals with extraordinary foreign ties and (b) those of apparent foreign (elite-status?) individuals." Exchange between Maya and Teotihuacan elites is evidenced at Teotihuacan by the cylindrical vases in the Xolalpan Compound burials cited above, by occasional finds of carved Maya jade at Teotihuacan, by Maya vessels in graves such as the "Kaminaljuyú style" vase from La Ventilla A (Plate X) or the two Polychrome jars in Burial 22, Mezquititla (fig. 18, Plate XIX) and by the "Pinturas Realistas" in which Maya are depicted with "typical" attire and facial characteristics in murals at Tetitla (C. Millon 1972).

\section{ETHNIC BARRIOS}

The Late Classic burials at the Merchants' Barrio are associated with late construction and occupation, an example being Circular Structure 15 at the La Nopalera site that contained Burial 33 (fig. 17) and the Patio on the south where Burial 34 was located. Burial 3 in Adoratorio 1 and Burials 17 and 18 next to Adoratorio 2 testify to the continued use of the Adoratorio in the Late Xolalpan phase. Shallow graves in Circular Structure 4 (Burials 10-12) and the shaft tomb Burials 13a and 13b (that contained two Maya Polychrome vessels in fragments) were of Late Xolalpan date. One incineration burial (Burial 13) was recovered in Adoratorio 1 of Late Xolalpan date. It is interesting to note that adults were sometimes buried in shrines at Tlajinga 33, Teotihuacan (Storey 1987).

The interaction between non-elites of contemporaneous cultures is an important phenomenon that probably took place at the Merchants' Barrio. The type of architecture, the peripheral location of the settlement on the northeastern edge of Teotihuacan, and evidence of large numbers of craftsmen at work signify that the members of this enclave belonged to the middle or commoner class with one or two higher statuses represented. In the Late Xolalpan phase where previously there had been round houses exclusively, a new rectangular stone-walled room complex built of large rough stones and tepetate-earth floors was built (Rattray 1987a, 1987b). Only in the central part of the Xocotitla site could this room complex be reconstructed. Compared with Tlamimilolpa the architecture is decidedly poorer; the Teotihuacan orientations of $15^{\circ} 30^{\prime}$ east of north are not followed as at Tlamimilolpa, and there are no talud-tablero facades. The quality of imported Gulf Coast-Maya ceramics diminishes in Late Xolalpan and Metepec times but does not cease, whereas trade in Thin Orange, particularly the amphora form, increases. Perhaps the Teotihuacanos were tightening control over pochteca groups from the Gulf Coast at the same time that events outside the city may have been a factor in the lessening of Teotihuacan influence and its controls over long distance trade and commerce. It has been known for some time that Teotihuacan's 


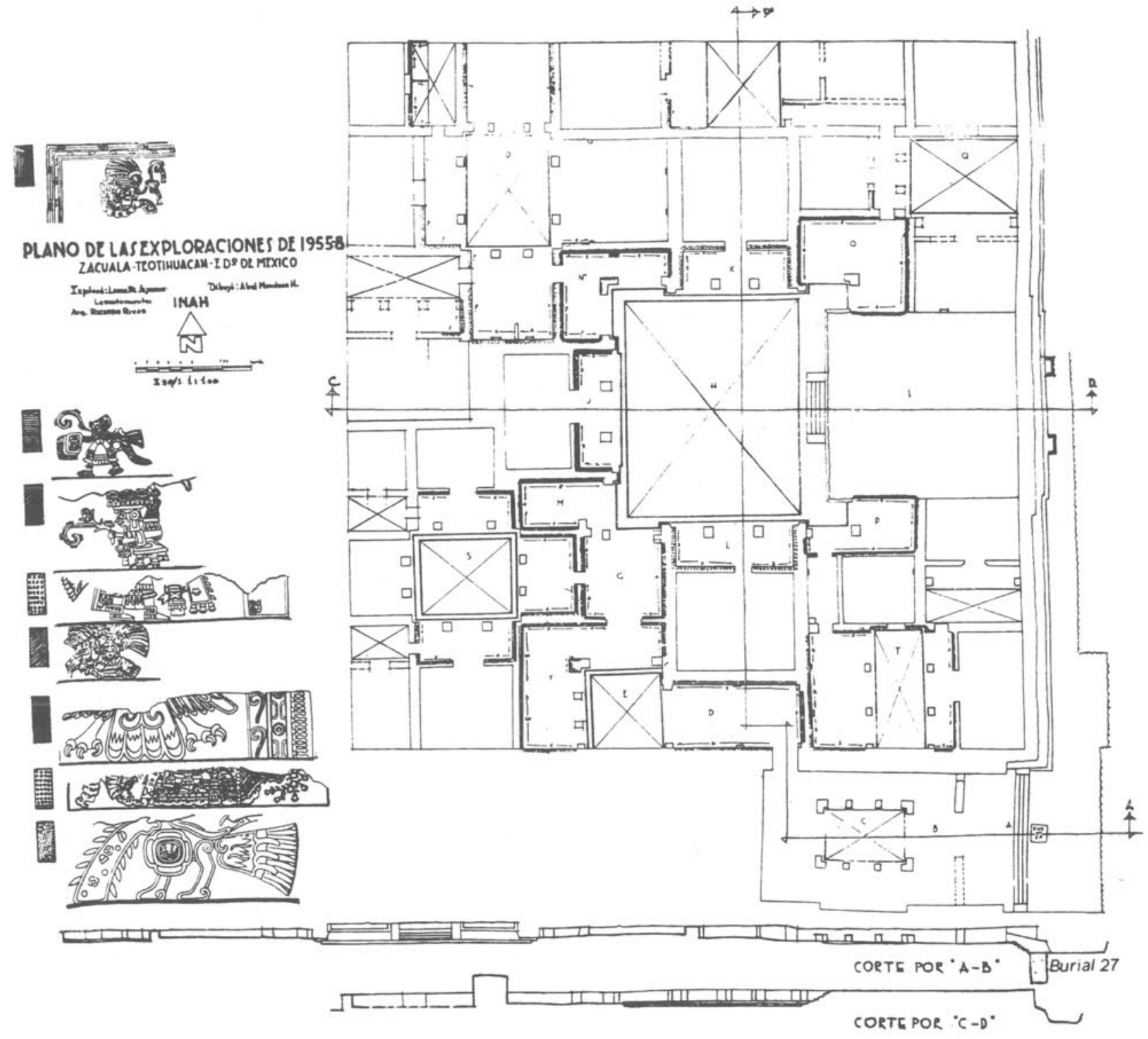

Figure 28: Plan of the 1955-1958 explorations at Zacuala Palace, Teotihuacan. Burial 27 was located at the foot of the steps of the main entrance to the Compound (Sejourne 1959, Figure 1). 


\section{YAYAHUALA}
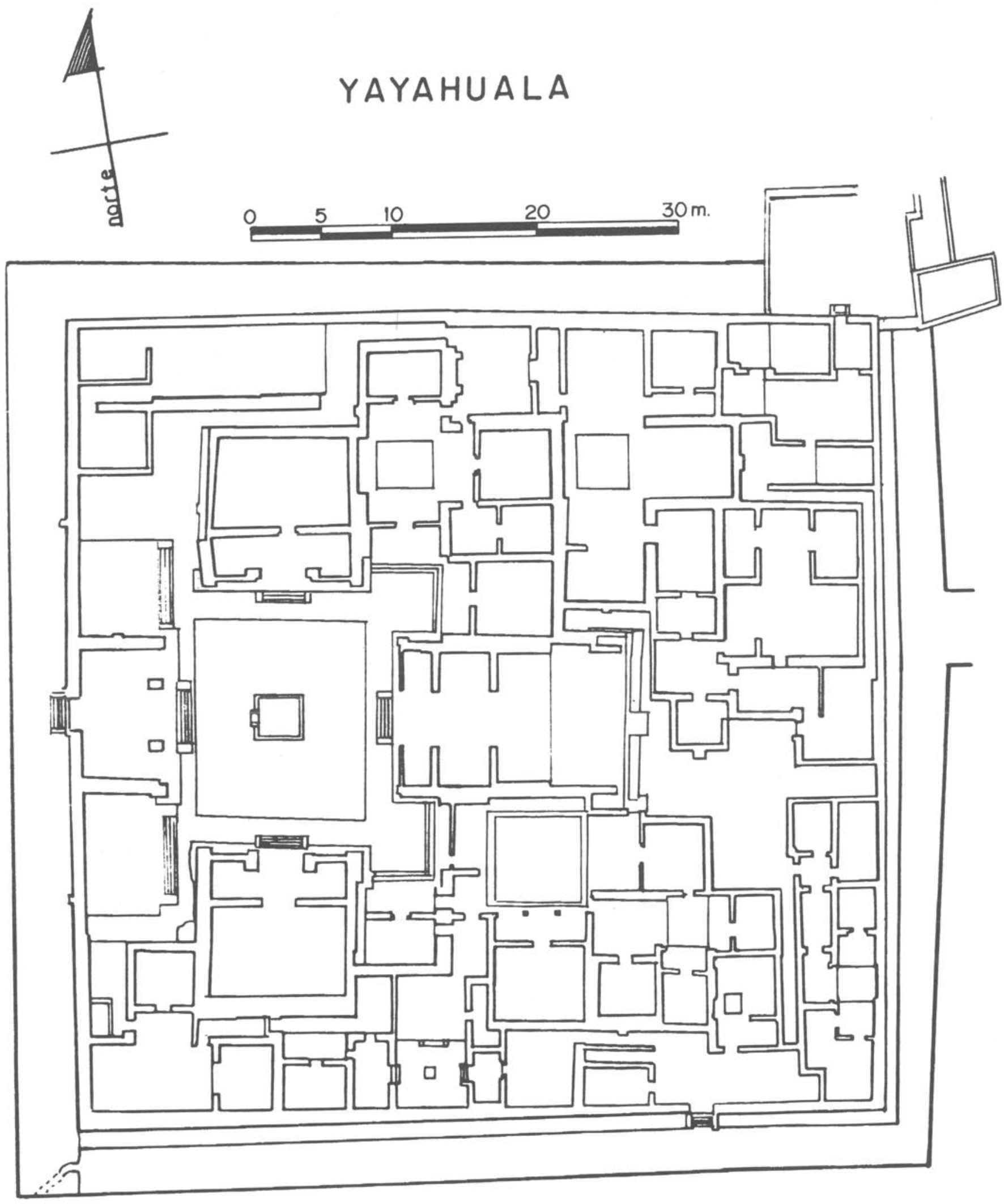

Figure 29: Plan of the Yayahuala Compound. Locations of Burials unknown (Sejourne 1966c, Figure 4). 


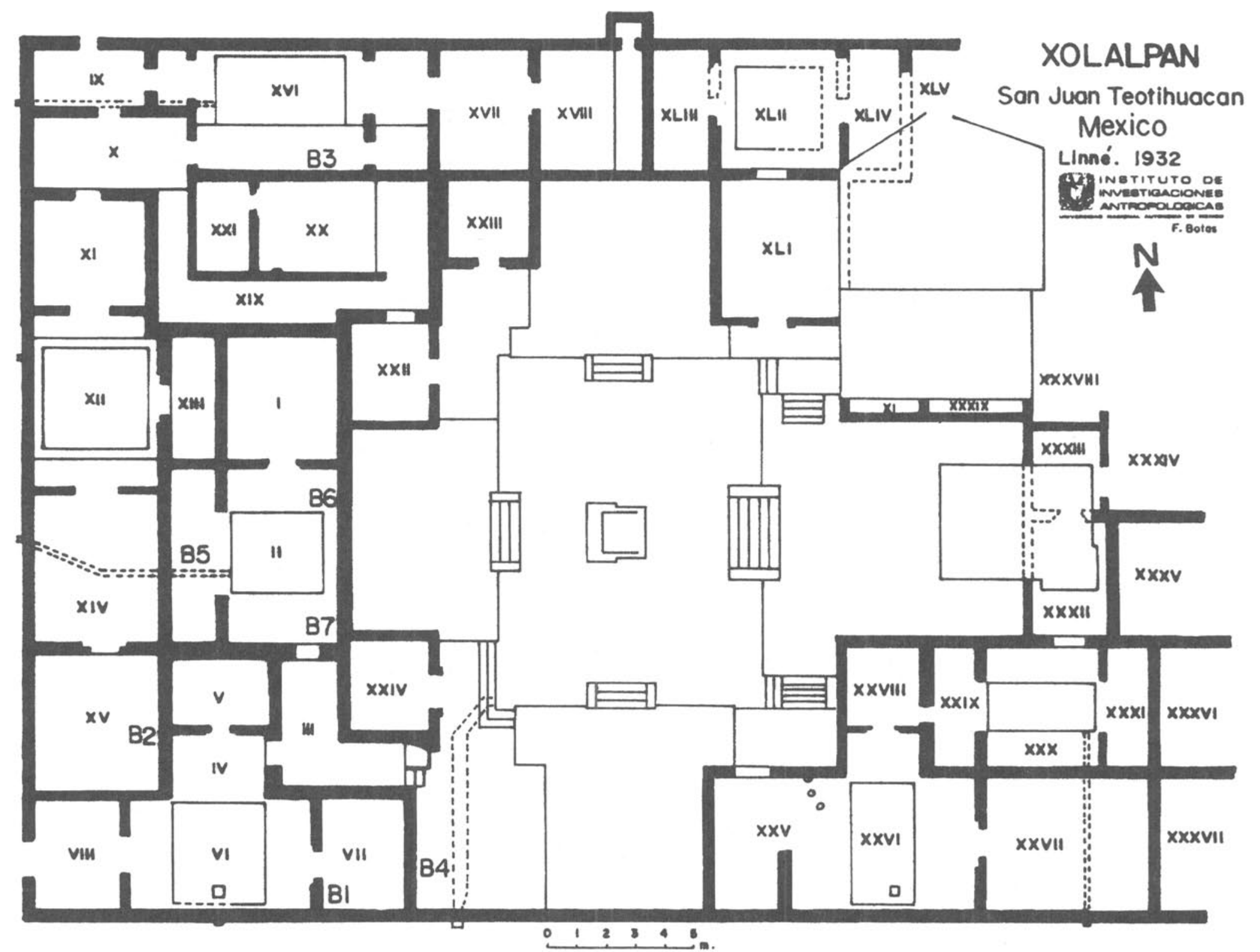

Figure 30: Plan of the Xolalpan Compound with Burials 1 to 7 indicated (Linne 1934, Figure 9). 


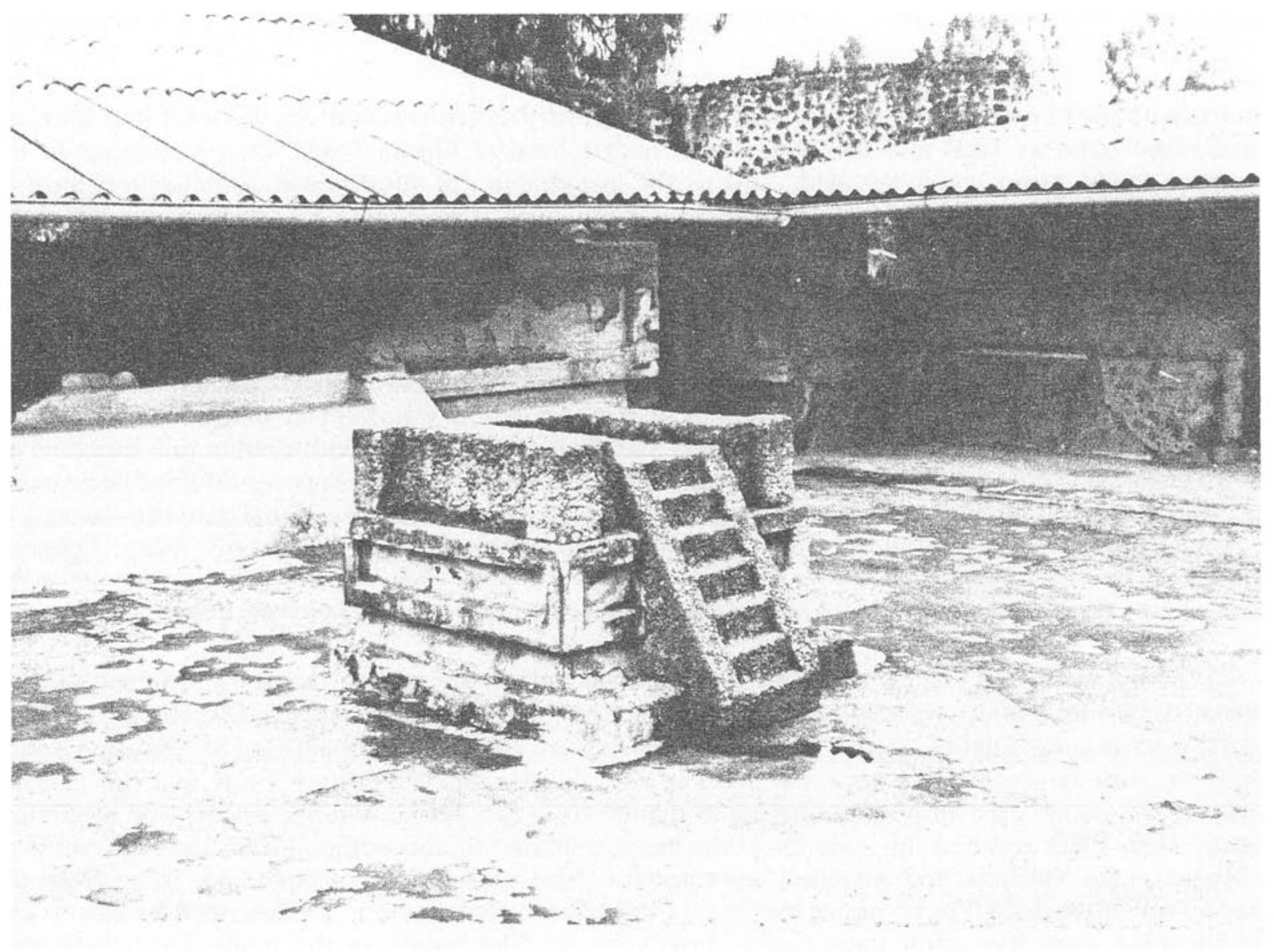

Plate XXIV: Tetitla, Southeast Temple Group

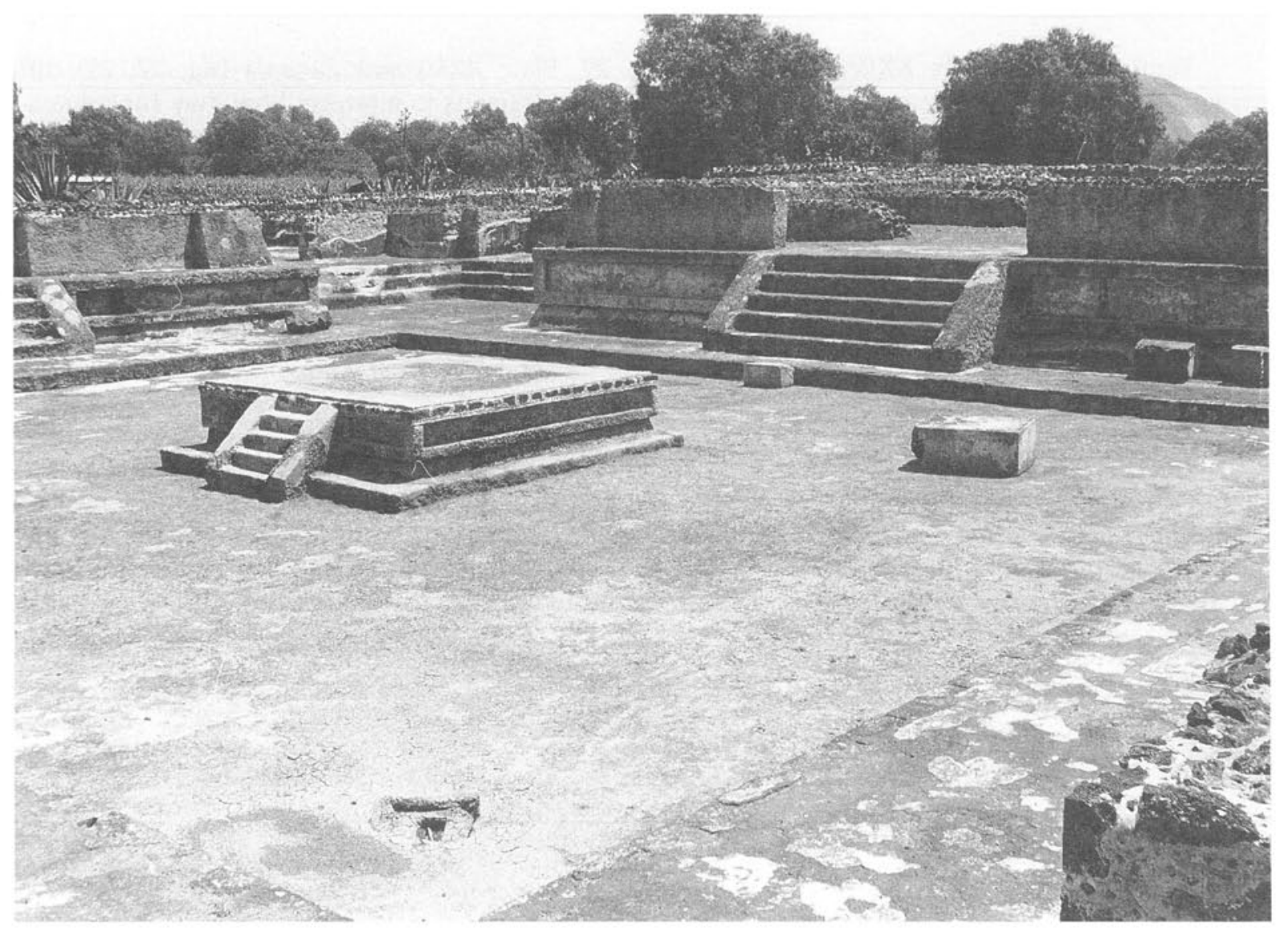

Plate XXV: Yayahuala, Main Plaza with Four Temple Complex 
contacts with the Maya region diminish after the sixth century as artifacts and vessels of Central Mexican manufacture cease at Tikal and continue in attenuated form at Kaminaljuyú, the phenomena of the Esperanza tombs never being repeated. Just as the introduction of talud-tablero architectural form in Tikal's Manik 2 (300-400 A.D.) indicated a fairly permanent commitment to Mexican values, so its abandonment by Manik 3A (400-500 A.D.) times reflects a lessening of commercial interaction and adherence to Mexican ideals (Laporte 1987).

At the Oaxaca Barrio there was new construction: the renovation of a major temple in the Barrio. Oaxaca tombs were used into Metepec times and sometimes burials were placed outside the tomb. A major east wall that extended along the length of the compound was built at this time. Gray ware ceramics, large apaxtles (tubs), sieves, deep bowls and fine serving dishes with double line incisions on the rim make up 5\% of the ceramics at the Barrio. In the Metepec phase, the Zapotec-oriented occupation (including ceramics) attenuates. Metepec incensarios and censer adornos show ritual activities related to the tomb, the last interment taking place just before the tomb was sealed and built over. Spence's excavations at Site 6: N1W6 revealed renovation of the central patio, new offerings and sealing off of the North tomb. The Monte Albán IIIA urn-smashing ceremony took place in Metepec times.

At the Tlajinga 33 compound the Late Xolalpan burials are of two types, those of individuals associated with the pottery making industry and the elite tomb burials. Perinatals (Burials 2, 5, 8, 9, 33 and 51) were accompanied by or placed in used Tlajinga ware bowls or the bottoms of San Martín Orange amphoras, with an occasional outcurving bowl as well (Storey 1987). We now know that the Tlajinga bowls are the molds used in pottery making to manufacture San Martín Orange kraters and amphoras (Rattray 1983, 1988) and that the majority of the peoples inhabiting this compound in the final phase of occupation, Late Xolalpan and Metepec, were potters. The second type of burial are those from the specially constructed shaft tomb under the floor of the Altar in Courtyard 3. As described by Storey and Widmer there were five adult individuals (Burials 50a to 50e) buried in the tomb which had been disturbed to remove the burial offering but the skeletal material placed below the offering had been left intact. The tomb was L-shaped ( $1.9 \mathrm{~m}$ long by $1.6 \mathrm{~m}$ wide) and had been dug to a depth of $2 \mathrm{~m}$ into the tepetate substratum.

Tetitla (fig. 25, Plate XXIV), Yayahuala (fig. 29, Plate XXV) and Zacuala (fig. 27, 28) differ enormously from one another architecturally and it is difficult for us to interpret how they functioned in ancient times. The excavations were not carried out in such a way as to recover contexts of artifacts and information on behavior. Nevertheless the data that Séjourné has given us are invaluable, and without her report we would have very little knowledge of compounds. The three she investigated are walled compounds, differing from barrios on the outskirts of the city such as Tlamimilolpa, Xocotitla and Mezquititla (Merchants' Barrio), Tlajinga 33, and probably La Ventilla B that were more like neighborhoods that grew through accretion. It has been suggested that Yayahuala might have functioned as the barrio temple center, Tetitla as a governmental center or alternatively as a school, and Zacuala as a palatial mansion (Angulo 1987). Functionally they differ from most known centers in that they incorporate residence with place of work (Millon 1976).

Azcapotzalco, an area closely linked to Teotihuacan throughout its existence, was probably the recipient of emigrants from Teotihuacan toward the end of the Classic Period. The late burials and offerings for which we have information at Pueblo Perdido, San Bartolo Naucalpan closely parallel those of Teotihuacan throughout the Classic. Pertaining to the Metepec phase we found an infant burial with a Polished brown ringbase bowl, inscribed with a pyramid-temple and bulto (burial bundle) on the interior (fig. 10c-e). 


\section{EXCAVATIONS AND CHRONOLOGY OF THE TEOTIHUACAN BURIALS}

\section{THE OSTOYAHUALCO EXCAVATIONS}

The site of Ostoyahualco, located within the district known as the "Old City" because of the extensive Patlachique and Tzacualli phase archaeological remains recovered there, is located approximately $800 \mathrm{~m}$ northwest of the Pyramid of the Moon (fig. 1). A preliminary reconnaissance of the Ostoyahualco region was made by Cook de Leonard in 1951 at which time she explored in and around several of the caves in the vicinity, determining that they had been inhabited from Teotihuacan I times or earlier, with occupation continuing up to the present at El Rancho de Ostoyahualco (Cook de Leonard 1952: 49). At Plaza One, Ostoyohualco, she excavated a low platform to the south and discovered below it several superimposed floors, part of the habitation, and an infant burial associated with Early Teotihuacan (Tzacualli) ceramics that she interpreted as a possible sacrifice upon the erection of the structure (Cook de Leonard 1957b: 1). Plaza One, a typical three-temple complex, is made up of the main Plaza and three good-sized mounds ( $6 \mathrm{~m}$ or $7 \mathrm{~m}$ high) on the east, west and north (fig. 2). In 1957 extensive excavation was carried out in the south platform (Cook de Leonard 1957b; Millon 1957) finding indisputable evidence of Teotihuacan I (Early Tzacualli) occupation in the deepest levels of the stratigraphic pits. Abundant sherds and two nearly complete vessels, one a negative bichrome black on red, were recovered. The ceramics recovered were similar to those found within the core of the Pyramid of the Sun. In the uppermost levels the cultural remains of occupations of a much later date were recovered, i.e. Xolalpan Phase Teotihuacan, and Postclassic Toltec and Aztec sherds.

Further excavations in 1959 by Millon and Bennyhoff $(1961 ; 516-517)$ of five pits along the north side of the south platform revealed a long sequence of occupation from Early Tzacualli to Mazapan times. The important discovery of seven excellent caches of Early Tzacualli ceramics (no human skeletons were present) was made in the deep levels under several earthen floors (Millon 1957, 1960; Millon and Bennyhoff 1961; Millon, Drewitt and Bennyhoff 1965). The floors probably belonged to habitations or simple religious structures of adobe and wattle-and-daub (Millon and Bennyhoff 1961: 516-519). The caches contained exotic wares, i.e. Resist or Negative-Painted vessels in several shapes (cylindrical vases, simple bowls, bi-pinched and compound silhouette bowls and jars). The floors and deep layers of rubble above the caches produced large quantities of utilitarian pottery that rounded out considerably the picture of the ceramics of the Early Tzacualli phase (Rattray 1973, 1981). The configuration of structures at Ostoyahualco consists of a plaza bordered by a platform with temples on the west, north and east (fig. 2). The caches were located in the South Platform.

The next stage of exploration at the site was a tunneling operation into the central temple platform to investigate the interior matrix and determine whether there were earlier structures inside. This operation, done in the rear of Mound B, yielded unique data on burial customs of this Early Tzacualli phase (Cook de Leonard 1971: 191). Twelve burials in all were unearthed, ten recovered. These were adults in flexed positions that had been wrapped mummy-style, many associated with "Tlaloc floreros" coated with ochre paint (Plate II). For a short description of Cook de Leonard's excavations, see Nicholson (1959: 306).

\section{THE CIUDADELA EXCAVATIONS: TEMPLE OF QUETZALCOATL}

The Temple of Quetzalcoatl located on the east in the great plaza of the Ciudadela (fig. 1) was the focus of several early excavations in which offerings and burials were recovered. In the process of excavating the "Templo Viejo", the earliest of the two constructions, Dozal (1925: 218) discovered at the four corners, human skeletons buried with offerings, almost certainly sacrificial victims killed at the time of building. Moreover, the associated offerings are like those found in the recently discovered multiple burials on the south and east sides and "were probably warriors" (Sugiyama 1986). From 1917 to the early 1920 's excavations were carried out in the Ciudadela by Gamio (1922) and others. Important dedicatory 
caches such as the one discovered at the base of the Temple of Quetzalcoatl in front of the stairway and the discoveries made in the upper part of the Temple have been described by Marquina (see Gamio 1922: 157-158) and Rubín de la Borbolla (1947). We lack precise information on these early explorations in the Temple of Quetzalcoatl.

Excellent new data come from the recent work of the Proyecto Arqueológico Teotihuacan (Cabrera et al 1982) and the excavations subsequently carried out by Sugiyama $(1986,1989)$. Sugiyama discovered "a ritual grave complex dedicated to the Old Temple of Quetzalcoatl" in which there were eighteen individuals found in an enormous burial pit below the south facade near the center of the Temple (fig. 4). A symmetrical pattern of the dedicatory caches emerged that led to the discovery of a corresponding multiple grave on the north side of the Temple (Jarquín and Martínez, personal communication 1986; Sugiyama 1986). Although rich in other goods (obsidian and shell artifacts), these sacrificial burials have few ceramic offerings and pose a problem for dating. The radiocarbon dates ${ }^{14}$ suggest the ceremonial sacrifices took place in Miccaotli and Early Tlamimilolpa phases.

The first burial found (Burial 153) was discovered fortuitously on the south side of the Temple when a stratigraphic pit was made (Sugiyama 1986). It was a young female found in dorsal flexed position with the arm bones in such a position that they appear to have been tied behind the back. Associated with the skeleton were 1,606 small worked snail shells (species olivella semostriata) from the Pacific Ocean. Next, a multiple burial (Burial 190) was found at the center of the south side of the Temple where a long pit measuring $8.25 \mathrm{~m}$ long and $1.8 \mathrm{~m}$ wide had been dug into the tepetate, in which 18 individuals were lined up with their offerings. Burial 203 was the last to be discovered by the Proyecto Arqueológico Teotihuacan 1980-1982. It was placed in the same relationship to the Temple as was Burial 153 on the west side of the long pit.

The Project "Temple of Quetzalcoatl", under the joint directorship of George Cowgill and Ruben Cabrera, was designed to investigate problems of the religious practices, politics and ideology of the ancient inhabitants of Teotihuacan (Cabrera et al 1989, 1990). In the 1989 field season, a tunnel penetrating from the south side was made for the purpose of investigating the interior of the temple to find earlier

structures. Two large tombs were encountered running east-west: Tomb 1 contained 8 skeletons, 6 of which were young adult males; Tomb 2 contained 18 individuals, lined up with rich offerings like earlier discoveries and most notably with slate disks, tezcacuitlapilli, located at the back near the vertebral column-a type of medallion customarily worn by warriors. Two periods of sacrificial burial practices were identified: one at the time the foundations of the Temple were lain; and the second upon its inauguration. Other burial caches were discovered on the north side of the Temple. By the end of the second season 126 skeletons had been discovered. The offerings associated with the majority of the burials were similar to the objects from Burial 190 (ibid., 1989, 1990).

\section{THE CIUDADELA PALACES}

In 1972, for the purpose of recovering stratigraphic data on early ceramic phases for the Teotihuacan Ceramic Chronology, I undertook excavations in the Ciudadela South Palace and the South Transverse Platform (Rattray 1973). We located Pit TE $25 \mathrm{~N}$ in the north central room with a portico in the complex previously excavated by Gamio in the northwest corner of the Ciudadela's South Palace, and Pit TE 25S in one of the rooms on the top of the South Transverse Platform. Meters of occupational debris composed of Early Tlamimilolpa phase ceramics were recovered from throughout all layers of Pits TE $25 \mathrm{~N}$ and TE 25S, including those resting on bedrock. In the upper layers of TE $25 \mathrm{~S}$ we encountered three Metepec floors and directly underneath were the Early Tlamimilolpa levels. Apparently all the Xolalpan occupational levels had been scraped away before the renovations to the Platform were made. A single cache, Cache 9b, containing a fine stucco Painted bowl of Early Tlamimilolpa date was recovered from the South Palace. 
The Palaces cover approximately 4000 square meters each and are located North and South of the Temple of Quetzalcoatl. They are limited on the West by the Transverse Platforms and on the East by the Great East Platform. As part of INAH's Proyecto Arqueológico Teotihuacan 1980-1982, excavations were carried out there by Martínez, Jarquín and Romero (Cabrera et al 1982). The North and South Palaces bear similar layouts consisting of five units each arranged around a central plaza. They were built in their present plan by Early Tlamimilolpa times (Jarquín and Martínez 1982). Excavations under the North Palace uncovered some earlier structures dating to the Tzacualli-Miccaotli phases. These were two small platforms and structures not unlike the "habitational platforms" just outside the Ciudadela on the Avenue of the Dead (Cabrera and Soruco 1982). The ceramic materials and burials recovered during the course of excavations leave no doubt that the Ciudadela Palaces were occupied without interruption from the Tlamimilolpa to Metepec phases. Data on the burials and offerings encountered in the North Palace are incomplete and pertain to four burials reported by Jarquín and Martínez (1982: 103) dating apparently to the Late Xolalpan-Metepec phases.

\section{LA VENTILLA A COMPOUND EXCAVATIONS}

The discovery of a magnificent ballcourt marker on the La Ventilla ranch about $600 \mathrm{~m}$ southeast of the Ciudadela (Aveleyra Arroyo de Anda 1963) prompted Piña Chan (1963) to excavate parts of three compounds at La Ventilla called "Sistemas I, II and III". He found temple platforms, plazas, altars, and over 16 burials and offerings placed under the concrete floors (Piña Chan's plans of La Ventilla A, Systems I II, and III are reproduced in greatly reduced form in Millon, Drewitt, and Cowgill 1973: Map 91 and in Millon 1976: fig. 13.)

The ritual burial of the La Ventilla stela almost certainly dates to the Early Tlamimilolpa phase. It was found between two floors, resting on the lowermost. Next to it was a platform or altar with a hole in the center where a ballcourt marker must once have stood. At the foot of the steps under a resealed floor was the burial of an adult with its offering consisting of red recurved bowls, a Tlaloc jar and Matte miniatures.

Of utmost importance for the study of foreign relationships was Piña Chan's discovery at La Ventilla A of Teotihuacan burials equipped with Gulf Coast vessels (see Aveleyra Arroyo de Anda 1963 for photographs of the vessels). He states:

...the numerous burials from below the floors accompanied by vessels with decorative elements characteristic of Veracruz, as well as the pieces of yokes (yugos), unworked shell, the stela, all seem to indicate that a group of artisans resided here who had strong commercial ties with the Gulf Coast region during Teotihuacan's apogee; and that this was a barrio where articles were made for distribution in the center (Piña Chan 1963: 52)

The inventories of the burials and offerings from the La Ventilla A materials indicate 2 offerings and 13 burial lots: 1 Early Tlamimilolpa, 4 Late Tlamimilolpa, and 8 Early Xolalpan burials. There were five burials containing Gulf Coast vessels, two of which were imported from El Tajín (Plate XI) (Rattray 1977, 1986; Harbottle and Sayre 1977). The third is a vase with a bird lid and scroll designs (Plate X).

\section{THE LA VENTILLA B COMPOUND EXCAVATIONS}

The La Ventilla B compound (fig. 6) was excavated by Juan Vidarte (1964: Plan 1) for the Mexican Proyecto Teotihuacan in what was basically a salvage operation, the compound having been previously razed by the modern owner. Among the features encountered were rooms arranged around patios; for 
example the room complex on the west, Patio 1 West; Patios 5 and 6 on the south; and on the east, the Adobe Room complex (fig. 6). This compound and Tlajinga 33 (Storey 1985) had some of the earliest burials found at Teotihuacan and attest to Early Tlamimilolpa beginnings for these compounds. Serrano and Lagunas (1975: 105) were responsible for the osteological studies on the human skeletal material from La Ventilla B. They reported 174 burials including 106 adults ( 43 males, 52 females), 8 juveniles, 24 infants, 34 prenatals and 2 of undetermined age and sex. Cremations were rare, only three indisputable examples--Salvage Burial XIII, Burials 19 and 34--being reported.

\section{THE TLAJINGA 33 EXCAVATIONS}

The Tlajinga 33 apartment compound, measuring approximately 50 by $60 \mathrm{~m}$ is located on the southern edge of the urban zone. Storey and Widmer, under the direction of William Sanders, excavated here in 1982, revealing a large sprawling compound built mainly of adobe walls, packed earth floors and paved courtyards (fig. 8), unlike most apartment compounds situated closer to the Avenue of the Dead which have masonry walls and plastered floors and walls. They identified 104 rooms pertaining to different phases in the area of $1250 \mathrm{~m}^{2}$ they excavated, whereas the entire compound has a maximal area of $2200 \mathrm{~m}^{2}$. Thus in actuality, $55 \%$ of the possible site area was excavated (Sanders, Storey and Widmer 1982).

They distinguished three building phases (from the Early Tlamimilolpa through Late Xolalpan phases) that showed a gradual accretional buildup laterally through the addition of rooms and architectural units, not just a vertical buildup of architecture as is so often the case closer to the Avenue of the Dead. A wealth of information was recovered not just on architecture (Widmer 1987a) and mortuary customs (Storey 1985, 1987), but on craft specialization as well, including ceramic manufacturing activity (Rattray 1983; Widmer and Sheehy 1990), lapidary working (Widmer 1987b) and subsistence data (Sanders, Storey and Widmer 1982).

The ceremonial courtyards proved to be one of the most useful categories of architecture for studying the burial customs of the ancient inhabitants of this compound. Dating was accomplished by means of ceramic phasing of the grave lots associated with burials found under the floors of courtyards, houses, and public structures (Widmer 1987a). Each courtyard complex was found to be spatially and temporally distinct. In Early Tlamimilolpa times the population was centered around the large cobbled courtyard with its associated building with portico on the east (a possible temple), located in the northeast corner of the site. In the Late Tlamimilolpa-Early Xolalpan phase and possibly continuing into Early Metepec times, the inhabitants' lives were focused on the central area of the compound where ceremonial Courtyard 3 was located. In this latter phase however, the entire compound seems to have been occupied and much activity revolved around the industry of pottery making. The workshops were located mainly in the northwest corner of the site. According to Widmer (1987a) the earliest structures were built of adobe with packed earth floors but in the last phases stone masonry and plastered concrete floors became common. In the Xolalpan phase the courtyard with its central altar shrine was paved and a temple with a balustraded staircase was built. Mapping of the entire residential plan for the Xolalpan phase was facilitated by this superior construction (fig. 8). The burials of each phase or group of phases were closely associated with each courtyard complex. The Late Tlamimilolpa-Early Xolalpan phase was the time during which the most burials were made, often associated with graves under rooms rather than in the main courtyard (Storey 1987). Good evidence of continuity of inhabitants was found in Burials 41-42 from the Enclosed Yard where seven individuals were buried. Two chronologically distinct burial episodes could be distinguished; one was Early Tlamimilolpa and the other Late Tlamimilolpa (Widmer 1987). Such continued use of the same disposal areas for burials also occurred at La Ventilla B in the Patio 5 and Patio 1 East areas. Another similarity between the burial customs of the Tlajinga 33 peoples and the La Ventilla B population is the burial of perinatals in altars. The altar associated with the southern courtyard area at Tlajinga 33 held the remains of four individuals (Burials 21a-21d) ranging in age from perinatal to young child. 


\section{THE OAXACA BARRIO}

The Oaxaca Barrio, also known as Tlailotlacan (fig. 11), is located in a peripheral zone of the city near the end of the west avenue. At site 7:N1W6 (Millon, Drewitt and Cowgill 1973: Map 70) is a zone of concentration of Oaxacan ceramics that was discovered by Teotihuacan Mapping Project archaeologists (Millon 1973). John Paddock and I were asked to carry out excavations at the site in 1966 (Paddock 1983; Rattray 1979) to determine the meaning of the Oaxacan sherds, the extent and nature of the apartment compound, and the period of occupation. A stratigraphic pit (fig. 11, Square W1N18) made through a series of building levels established the chronology of the site as Late Tlamimilolpa through Metepec with the possibility of earlier beginnings. On the southern extreme of the compound we found a multiple burial of three individuals in extended positions (fig. 12) associated with standard Teotihuacan vessels (Plate XIV) of the Late Xolalpan phase and a Monte Albán Transition II-IIIA urn (Plate XIII) (Caso, Bernal and Acosta 1967). Another Transition II-IIIA urn was found in a secondary burial under a floor at the northern end of the compound (Rattray 1987a, fig. 2h, i).

In the east room toward the center of the compound (fig. 11) under two floors we recovered Skull Burial C associated with an Early Xolalpan incensario (fig. 14, Plate XV). Excavations concentrated on investigating the major features within the $1.5 \mathrm{~m}$ by $1.5 \mathrm{~m}$ stratigraphic pit: a charcoal deposit in layer 4 on the west side; a skull burial in layers $4 a-4 b$ (fig. 14); and a pile of burnt feathers in layer 6 . Below layers 3 and $3 a$ at a depth of $60-65 \mathrm{~cm}$, where the hard-packed earth of the floor foundation ended, an intrusion into layers $4 \mathrm{a}$ and $4 \mathrm{~b}$ was detected in the southern corner of the pit. The location had been marked with a laja. It contained a cranium completely caved in on the top and next to it a complete incensario, also smashed. The burial pit was just large enough to accommodate the cranium and the incensario. According to Spence (personal communication 1988), the bones are those of an adult, probably a female. Associated artifacts included a bifacially chipped obsidian point, a bone needle, a bone tool, an obsidian blade and an obsidian core. We have determined that this event took place in Early Xolalpan times, both from the stylistic aspects of the incensario (the flange, the "elote" lid) and the sherds surrounding it and in the deposits below Burial $\mathrm{C} 1 .^{15}$

The Teotihuacan Mapping Project excavations at site 7:N1W6 (fig. 11; Millon 1967) uncovered a Zapotec-style tomb with an antechamber. At the entrance to the chamber was a carved stone doorjamb on which had been inscribed Zapotec glyphs. Ceramic analyses place the Oaxacan-style tomb in the Xolalpan phase. After initial use it was reopened several times before it was looted in Metepec times, then again in Aztec times. It represents the main concentration of skeletal material found in the Oaxaca Barrio. The tomb contained at least 6 individuals: 4 adults (males and females), 1 child and 1 perinatal. Spence's (1976) analysis of the skeletal remains for genetic relatedness suggests "some degree of homogeneity within the tomb, some among the individuals from beyond the tomb, and only limited genetic exchange between the two groups".

A magnificent Oaxacan urn (Millon 1967, 1973: fig. 58), the third to be discovered, was found in a room associated with a temple in the southeast part of the compound (fig. 11). This ritually smashed but complete Monte Albán III urn represents the "God with Serpent Mask" and was discovered by Vidarte of the Teotihuacan Mapping Project. A few Metepec phase sherds were associated with the urn smashing rites.

The architecture of the apartment compound is strictly Teotihuacan-style as are some offerings and burials. The tombs seem to have been built into existing structures. Recent excavations by Spence (1989) in the Oaxaca Barrio have led to the discovery of four more tombs in an adjacent compound (Site 6: N1W6). The presence of these cultural traits establish beyond any doubt the Zapotec identity of this barrio's inhabitants. Burial practices included the interment of individuals in extended positions with Zapotec funerary vessels (Rattray 1987a) and Zapotec-style tombs. 


\section{THE MERCHANTS' BARRIO EXCAVATIONS}

Excavations in the northeastern part of the city have revealed a barrio with distinctive architecture, layout and ceramics that contrast strongly with the remainder of Teotihuacan (figs. 15-17; Rattray 1984, 1987b, 1991). The predominant architectural form within the Barrio is the round structure with adobe walls (Plate XVI), unpartitioned and roofed over in perishable materials. I excavated eighteen of these circular structures, ranging in size from $5 \mathrm{~m}$ to $9.5 \mathrm{~m}$ in diameter, extending along both sides of the wide ravine or barranca cut by the San Juan river. The barrio covers approximately one third of a square kilometer (if we include the barranca that presently measures $80 \mathrm{~m}$ across). Approximately one-tenth of the barrio or about $3000 \mathrm{~m}^{2}$ was excavated. The barrio shows strong affiliations with Gulf Coast cultures (the Huaxteca and Tuxtlas regions) and with cultures of the Maya Lowlands (Coastal Yucatan and Lowland Peten regions) of the Early Classic period (Rattray 1991).

A large body of data on burial customs was collected in three seasons of work (Rattray 1985). A skeletal population of 80 individuals was recovered in three seasons of work at the barrio. Physical anthropologist Magalí Civera is currently studying the overall demographic characteristics of the Merchants' Barrio population and plans comparative studies with populations at other sites in Teotihuacan. The age and sex determinations in the inventories were provided by Civera $(1983,1989)$ who says the individuals are characteristic of family groups represented by 24 males, 23 females and 33 of undetermined sex. One interesting finding was the poor representation of individuals between the ages of 13 and 20 years.

The burials and offerings of the Merchants' Barrio are characterized by high incidences of secondary and multiple burials, significantly higher than in other barrios in Teotihuacan such as La Ventilla B and Tlajinga 33. The dead were buried under the floors of the circular structures. Circular Structure 2 contained 34 individuals, Circular Structure 4 contained 7 individuals, and Circular Structure 12 had 8 individuals (fig. 20). Other unusual customs included the burying of adults in specially constructed "adoratorios" or shrines in the plazas. At Xocotitla a shaft tomb was found under Circular Structure 4. Rare shrine burials of adults have been reported at Tlajinga 33 (Storey 1987) and at the Oaxaca Barrio (Spence 1989). The primary use of the five Adoratorios in the Merchants' Barrio was for burials. Adoratorios 1 and 5 held single individuals, whereas Adoratorio 2 (fig. 19), 3 (fig. 20) and 4, were the final repositories of multiple individuals. Adoratorio 4 had been deliberately emptied and carefully resealed. The range in ages of the individuals suggests continued reuse of the Adoratorios for individuals of the same family. It seems to have been customary to rebury the bones of the previously deceased with a more recent interment, the latter often being the only primary burial in the pit or shrine. The location of the Adoratorios in the main courtyard where the dead could be honored publically is indicative of ancestor worship.

\section{THE TLAMIMILOLPA COMPOUND EXCAVATIONS}

The Tlamimilolpa compound (fig. 22), located about $1.2 \mathrm{~km}$ due east of the Pyramid of the Sun and $200 \mathrm{~m}$ east of the church in the present-day barrio of San Francisco Mazapán was excavated extensively by Linné in 1935. Linné (1942: 95) uncovered "a medley of courtyards and rooms...not at all like a single building, but more in the nature of a small village." With some 20 workmen, he duc 176 rooms (out of an estimated 300) in addition to courtyards and passages, never reaching the limits of the compound or finding any evidence that it was surrounded by high enclosing walls. He determined that there were three different building levels in most parts of the site. Near the center in the area bounded by Rooms 27, 12, 5 and 36 he excavated to bedrock, describing the three levels in some detail although only the plan drawing of the uppermost is published (ibid., fig.188, Plate 1). Talud-tablero facades, although rare, occurred occasionally on the middle phase constructions. The entire area excavated was $3500 \mathrm{~m}^{2}$. Interpreting from the plans and Linné's description, one sees that the compound divides into a number of suites (The practice of building high thresholds would have made it difficult to distinguish 
between doors and walls). The walls were usually faced with stucco and painted red or white; concrete floors were given a finishing coat of stucco. Linné implies that early building plans were fairly similar to the final one published. The layouts of the Late Xolalpan and Metepec phase construction must have been fairly similar; the plan of the Late Tlamimilolpa plase construction is not known. The late construction filled in previously vacant spaces, partitioned rooms, replaces stairways, made new entrances and closed others off. The compound may originally have been made up of several separate buildings that were later joined. Information pertaining to the earliest period or "stage" gives the impression that the rooms were somewhat larger and constructed mainly with adobe walls.

The Xolalpan-Metepec phase compound, i.e. the uppermost structure that Linné exposed, has stone and plaster construction whereas earlier constructions were built by incorporating adobe walls and floors. ${ }^{16}$

\section{THE 1983 EXCAVATIONS AT TLAMIMILOLPA}

As part of the Merchants' Barrio Project (Rattray 1984, 1987b, 1989), parts of the Tlamimilolpa compound were re-excavated to determine how they compared chronologically and architecturally with the Barrio. The excavations were located adjacent to the $300 \mathrm{~m}^{2}$ area dug deeply in previous excavations (fig. 23; Linné 1942: 188) in a slightly mounded area where floors and walls were still exposed. I reexcavated Room 54, Rooms 59 and 15 and the corridor to the north, Room 56, a small courtyard and part of Room 60, a total area of $105 \mathrm{~m}^{2}$ (fig. 23). Linné had described Room 56 as "a cross between a room and a platform" because it was raised about $1 \mathrm{~m}$ above the level of the courtyard. It has a western access with a talud-tablero facade and is flanked by two columns--one of the few such facades in this compound. The structure facing it has an inset stairway, and is slightly higher.

We investigated the penultimate compound by clearing the looters' holes and test-pitting, discovering five additional burials ( 2 adults and 3 perinatals). A test pit made in Room 56 to investigate the stratigraphic layering, encountered instead a large burial pit, Burial 1-83 (fig. 24). The pit, located in the northeast corner of Room 56, was unusually large and deep and marked by a carefully sealed square patch on Floor 1. The individual buried there, probably an adult, had been partially cremated, the offering being made up of Early Xolalpan vessels (a vase, a jar, two outcurving bowls, slate and mica fragments). Room 15 also contained a round burial pit measuring $1.46 \mathrm{~m}$ in depth and $2.5 \mathrm{~m}$ in diameter that had been looted. A few bones, possibly of an adult, and fragments of a once-rich offering were recovered. These included pieces of mica, Matte ware ollitas, large fragments of an Early Xolalpan incensario, a face mask, an appliquéd collar, feathered disks, several plaques with yellow pigment, and other items.

There was a stairway in Room 15 East with concrete facing continuous with Concrete Floor 2 that led east to Room 59. This stairway had been neatly cut down, perhaps in earlier excavations, and part of an earlier stairway was exposed underneath. Although we were unable to uncover the earlier building in its entirety, we could date the construction to the Late Xolalpan phase. In the two east corners of Room 15 at the level of Concrete-Mud Floor 2, we recovered two infant burials with offerings of Polished outcurving bowls. The bones were extremely fragile and disintegrated rapidly. A third and fourth infant were recovered in the south wall of this room, accompanied by Late Xolalpan outcurving bowls. The infant burials appear to have been offerings dedicated upon renovation of the new building.

\section{THE XOLALPAN COMPOUND}

Located approximately $.5 \mathrm{~km}$ west of the Tlamimilolpa compund and the Merchants' Barrio in the present day barrio of San Francisco Mazapán is the Xolalpan Compound (fig. 30). Its layout is elegant and spacious, contrasting strongly with the contemporaneous Tlamimilolpa compound. The Xolalpan compound has the classic layout of a central courtyard flanked by four temple platforms, whereas 
Tlamimilolpa lacks the central temple-plaza group. The principal temple at Xolalpan is on the east and has a wide stairway. Of special interest is a T-shaped "sacrificial altar" (Linné 1934) in the center of the courtyard that had been plastered and painted red. On the top were postholes suggestive of "perishable roofing of pyramidal shape and open to the east" (ibid.: fig. 9). I excavated five altars, possible ancestral shrines, of similar shape at the Merchants' Barrio (fig. 15, 16), all containing burials (Rattray 1987b). Built around the four principal platforms of Xolalpan are groups of rooms that make up separate suites (Linné 1934: figs. 8, 9), each opening on the main courtyard and with outside entrances as well. Seven burials dating to the Xolalpan and Metepec phases were recovered from the apartments on the west side. They were richly stocked with fine cylindrical vases and other artifacts symbolizing the wealth and importance of the individuals.

\section{THE TETITLA COMPOUND EXCAVATIONS}

The apartment compund known as Tetitla is situated approximately one kilometer southwest of the Pyramid of the Sun (figs. 25, 26). It was partially excavated by Armillas in 1945 (1950: 55-56). Teotihuacan Mapping Project Test Excavation 24 was located within the area excavated by Armillas in the same southeast section of the Tetitla complex (fig. 25). In the earliest layers in a stratigraphic pit, we (Rattray 1969; Millon 1973) found excellent Late Tlamimilolpa deposits situated less than 5m from Armillas' excavation where he discovered the burial. Armillas says the offering vessels were "similar to those from under the floors of the Viking group or Group 5'." Given the present burial chronology and the ceramics we recovered in Test Pit 24, this burial probably dates to the Tlamimilolpa phase rather than to the Miccaotli phase as Armillas claimed.

Moore (1966: 70, fig. 1, Plates I-IV) excavated a portion of the Tetitla compound in 1951 finding a large burial offering, Burial 1, and a Hearth Cache that he compared to Burial 1 at Tlamimilolpa (Moore 1966: 84, fig. 5). Based on a careful analysis I would revise his phasing of Burial 1 to the Late Xolalpan phase and Hearth Caches 1 and 2 to the Early Xolalpan phase. At the time Armillas' and Moore's excavations were carried out, only a small section of the compound was known. Since then, it has been completely cleared (Séjourné 1966a). The remains of its walls bear some of the most beautiful mural paintings at Teotihuacan and its recent full exploration reveals it as one of the finest compounds known in the city. The building measures $70 \mathrm{~m}$ on each side and is bordered on all sides by narrow streets. Séjourné (ibid.: figs. 220, 221) excavated the apartment compound in 1963 and 1964 and two years later published the ceramics and complete plans of the second and third building levels showing the locations of offerings and burials. The 33 burials came from level 3 (fig. 25) whereas the majority of the offerings came from level 2 of the compound (fig. 26). Séjourné states:

With its clearly defined levels the Tetitla building helped elucidate the problem of the relationship of the burials to the different strata of the structure. The two upper levels lacked mortuary offerings altogether; whereas in the deepest levels, strangely, the many circular cavities were at times empty; other times they held human remains in inexplicably deteriorated state.

The practice of placing ritual offerings continues throughout the occupation of Tetitla from the Late Tlamimilolpa to Metepec phases. Fourteen occurred in the second level and seventy-one in the third level. Little information other than compound location is available for many offerings. Six of them were clustered in a large patio in the north central part of the compound. The offerings at Tetitla fall into two categories: the majority are associated with incensarios and others are quite like the mortuary offerings. Incensarios are distinctive composite forms that incorporate simple unadorned basins, a chimney, a frame and decorative elements into complex constructions. The frequency with which incensarios are found as dedicatory offerings and occasionally with burials is indicative of their ceremonial nature. Séjourné (1959: 117, fig. 47) found a complete censer in Burial 10 at Zacuala Patios ${ }^{17}$, calling them "miniature theatre 
altars". This kind of censer has been referred to as a "brasero ritual" (Gamio 1922: 196-200), an "incensario" (Linné 1954: 171-175), an "incense burner" (Kidder, Jennings and Shook 1946: fig. 201) and a "brasero"

(Séjourné 1966a, 1959: 117, figs. 97, 99-106). A Late Xolalpan incensario from Tetitla Offering 29 is illustrated in Plate XX.

The classification of the Tetitla burials from Séjournés excavations shows a high proportion dating to the Late Xolalpan and Metepec phases. Distribution is as follows:

\begin{tabular}{lcc}
\multicolumn{1}{c}{ Phase } & Burials & Offerings \\
Late Tlamimilolpa & 3 & 2 \\
Early Xolalpan & 7 & 9 \\
Late Xolalpan & 10 & 8 \\
Metepec & 9 & 13 \\
Unphased & 6 & 4
\end{tabular}

\section{THE ZACUALA PATIOS AND ZACUALA PALACE EXCAVATIONS}

Zacuala Patios and Zacuala Palace were excavated by Séjourné from 1955 to 1958 (figs. 27, 28). Well preserved wall stubs and concrete floors belonging to the uppermost and final buildings revealed remnants of magnificent murals, a large interior court and a wide stairway leading to a central temple, spacious rooms and some thirty burials with their associated offerings. In her account of the excavation, Séjourné (1966c: 11) states that "after long months of attempting to unravel the chaos of superimposed buildings, we finally began to discover the structural plan" (see Séjourné 1966c: fig. 3 for overall plan; Séjourné 1959: fig. 1 for partial plan of Zacuala Palace; Séjourné 1959: fig. 35 for plan of Zacuala Patios). Her description follows:

The Palace measures $60 \mathrm{~m} \times 60 \mathrm{~m}$ and covers approximately 4,000 square meters. The structure consists of interior rooms and porticos distributed around thirteen patios bordered by colonnaded rooms. The central patio, much larger than the others, is dominated by a temple that occupies the entire east side. Variations in the integration of the patios, porticos and rooms, break the monotony of the basic plan thereby creating a dynamic harmonious freedom that is so characteristic of the architecture of Zacuala. A magnificent stairway, 12 meters wide, allows access to the palace through a vestibule 21 meters long with a sunken patio in the center that must have been open to the sky and is bordered by 8 columns. (Séjourné 1959: 19)

In front of the main entrance, under a stuccoed floor, was discovered Burial 27, "the only burial associated with the palace" (fig. 28) (ibid.: 64, Lam. 36, 37). The burial contained an adult female, a large offering of ceramic pieces and jewelry in shell and jadeite, and pieces of mica and obsidian. The offering contained ceramic vessels that we consider to be representative of the Early Xolalpan phase. Continued excavations, subsequent to the publication of "Un Palacio en la Ciudad de los Dioses" (ibid.), led to the discovery of three additional burials in the Palace and one from the "Cámara Roja". ${ }^{18}$ 
Assuming that the occupancy of Zacuala patios and Zacuala Palace coincides with the burial sequence, the period of residence probably spans the Late Tlamimilolpa to Metepec phases (ca. 350-750 A.D. $)^{19,20}$. Some stratigraphic data appear in the plans of Zacuala Patios, but often crucial information indicating which interments might be intrusive into earlier buildings, whether floors were sealed over, and the number of reconstructions is lacking. The phasing of the burials has consequently been carried out largely on the basis of the stylistic characteristics of vessels placed in the graves as offerings. (See Appendix.)

\section{THE YAYAHUALA COMPOUND EXCAVATIONS}

The Yayahuala apartment compund (fig. 29), a complex of temples, patios and rooms located 70m north of Zacuala Palace was excavated by Séjourné in three seasons from 1958 to 1961 (Séjourné 1966a: 21-24; Noguera 1961). Yayahuala is unique compared to other known structures at Teotihuacan because of its broad, high entrance facing west that allows access to a main central patio bordered on three sides by large temples. It may have been the barrio temple (Séjourné 1966c: fig. 4). In the remainder of the compound the rooms are small and give the appearance of a crowded residential structure (Millon 1976: 225).

Outside the walled compound, on the east and north sides, the "basurero norte" or north dump was excavated by Noguera (1961) and Séjourné (1966a: 21-23). It was $2 \mathrm{~m}$ deep and filled the street on the north side of the compund. Excavations provided over 500,000 sherds dating mainly to the Xolalpan and Metepec phases. Muller (1959) describes briefly a stratigraphic trench that she dug in nine arbitrary layers of $30 \mathrm{~cm}$. each on the north side of Yayahuala. Materials recovered were Coyotlatelco and ProtoCoyotlatelco to a depth of $1.8 \mathrm{~m}$; below that from 1.8 to $2.5 \mathrm{~m}$ they were Teotihuacan IV (Metepec); and in the deepest layers--2.5 to $2.7 \mathrm{~m}$--they were Teotihuacan III (Xolalpan). Muller noted large numbers of water-worn sherds and figurines of the Miccaotli and Tlamimilolpa phases.

Our stratigraphic sequence for the Yayahuala compound is derived from a test pit made by Starbuck (1973) in a small room near the southeast corner of the compound. The primary purpose of the excavation was to recover faunal material in stratigraphic contexts. The earliest deposits were Late Tlamimilolpa phase in date and the latest were Metepec phase deposits. In the final phase of occupation of the compound an adult was buried under the Metepec floor, accompanied by a rather poor offering. This corner of Yayahuala was apparently built about 350 A.D., whereas the main compound with its temples may have been built earlier, the first constructions possibly in Early Tlamimilolpa times.

The burial data for the Yayahuala apartment compound are poor; no accounts of the excavations or the locations in the compound of the burials have been provided by Séjourné. Based on my inventory of the vesssels in the Museum collection, I have phased 10 burials out of the 26 reported. The provisional phasing of nine burial lots is: 3 Late Tlamimilolpa burials; 4 Early Xolalpan burials; 1 Late Xolalpan burial and 1 Metepec burial. The distribution of burials may indicate that Yayahuala had an earlier occupation than either Tetitla and Zacuala.

\section{INAH'S ARCHAEOLOGICAL PROJECT 1960-1964}

In the early 1960's during the presidency of López Mateos, the Mexican government sponsored major excavations at Teotihuacan, the "Proyecto Teotihuacan", under the direction of Ignacio Bernal (1963) with Jorge Acosta as field director. Excavations were dedicated mainly to the exploration and reconstruction of the "ceremonial center" of Teotihuacan. They excavated both sides of the Calle de los Muertos, the Pyramid of the Moon, and the immense U-shaped platform surrounding the Pyramid of the Sun, changing the aspect of Teotihuacan appreciably. Encompassed within the Proyecto Teotihuacan were the excavations of the compounds, La Ventilla A, B and C; Tetitla; Yayahuala and Zacuala which are discussed in the preceding pages. 
Another major focus of attention was the Quetzalpapalotl Palace (Palace of the Quetzal Butterfly) (Acosta 1964: Plan 1) also referred to as Palacio 3 (Bernal 1963) located on the west side of the Plaza of the Moon. Entrance to the Palace is gained by a wide stairway (Acosta 1964: Plans 1, 3, 4) that leads to two columned antechambers (Antesalas). In Antesala 1 near the center of the room the excavators encountered an enormous looters' hole at the bottom of which was an abandoned tomb, completely emptied of its contents in ancient times. It was constructed of stone and measured $4.75 \mathrm{~m}$ by $1.44 \mathrm{~m}$. Surprisingly few burials and offerings were recovered from the Palace. Two rather poor offerings, designated as 2 and 3, were recovered from below the structure of the north room of the Palace of the Columns (ibid.: 55). Acosta illustrates a possible burial from the north passageway showing scattered bones, a cranium and a fine Tlaloc figurine with the typical features of the deity (ibid.: fig. 58).

The "Ofrenda Desague" (Drain Offering) was located somewhere in the Quetzalpapalotl Palace (Muller 1978: 39-40). As director of the Instituto Nacional de Antropología e Historia ceramic laboratory, Muller (ibid.) carried out a series of stratigraphic excavations throughout the zone. The few burial lots that I could reconstruct using provenienced vessels from the Museum collection are: one burial from Palacio 3; two offerings from the "Ofrenda Desague"; one offering from the "Fosa Tepalcates", and one burial from Site 57, Pit 2 (Rattray 1978). From these data we made up the inventories presented in the Appendix.

\section{TEOTIHUACAN ARCHAEOLOGICAL PROJECT 1980-1982}

The most recent archaeological project of INAH, directed by Cabrera (Cabrera et al 1982), discovered over 100 burials in the course of excavations concentrated mainly on the southern part of the Calle de los Muertos. The majority of the burials were recovered from the Great Rectangle and the Ciudadela (González and Fuentes 1982). Important finds were made in the North Palace (Palacio 1D) by Jarquín and Martínez (1982). They recovered 4 burials with 15 individuals from a single room, one of the few with intact burials, although throughout the North Palace were burial pits that had been emptied in ancient times. In the Northwest compound located on the Calle de los Muertos, some 26 burials were recovered by INAH archaeologist Sánchez (1982:243). Physical anthropologists González and Fuentes (1982a, 1982b) were responsible for analyzing the skeletal material.

In the Great Rectangle north of the Ciudadela, Rodríguez (1982: 55-73, Plans 1,4) excavated two "semi-circular" structures similar to those of the Merchants' Barrio. (It is not inconceivable that originally they were full circles and are now partially destroyed.) The Great Rectangle is a large open plaza with three small temples located to the east, and is evidently a non-residential section of the city that was used for craft production of elite goods such as ceremonial incensarios, figurines and possibly feather works (Muñera 1985). Ten burials (2 primary and 8 secondary) with offerings from the Early Tlamimilolpa to Metepec phases were recovered from within the circular structures. Rodríguez interprets the use of the structures as "burial platforms" and "not as habitations of any kind". Pending the study of the archaeological materials we can hypothesize that perhaps the circular structures did function as religious shrines and as storage places for the pooling and redistribution of elite goods from the Gulf Coast and Maya regions. 


\section{APPENDIX I: THE BURIAL AND OFFERING INVENTORIES ${ }^{21}$}

Work was carried out on the burials and offerings that come from La Ventilla A and B, the Zacuala Compound and Patios, the Tetitla Compound, and the Yayahuala Compound in the storerooms of the National Museum of Anthropology in Mexico City (Rattray 1978). Provenience and accession numbers had been marked on each vessel making it possible for me to reassemble the burial lots. I made assessments on the relative chronological placement of each burial vessel and ultimately on entire burial lots. The latter was accomplished by physically grouping the vessels or the illustrations of the vessels on a table. After the entire collection of vessels in the "Sala Teotihuacana" and the storeroom of the Museum had been examined and classified, the inventories were compared with field inventories made by Vidarte (1964), notes taken by Bennyhoff (1964-1966) on the contents of each burial and others for La Ventilla A and B, and Séjourné's published works on the Tetitla compound, the Yayahuala compound, and Zacuala Palace and Patios. I found that the collections in the Museum of Anthropology were by no means complete even though I was allowed access to all the materials stored there. Sometimes an entire burial lot was missing or vessels from a lot were missing. The vessels present in the Museum in 1978 are recorded in the inventories with their accession number or designated simply "MNA". The original inventory has since been expanded and updated to include new materials that have come from new excavations. These are the excavations at the Merchants' Barrio (Rattray 1984, 1989, 1987a, 1988), Tlajinga 33 (Sanders, Storey and Widmer 1982, Storey 1985, 1987; Widmer 1987a), the Oaxaca Barrio (Rattray 1979, 1987a; Spence 1989), and the Proyecto Arqueológico Teotihuacan (Cabrera et al 1982; Jarquín and Martínez 1982; Sugiyama 1986, 1989).

The inventories of the ceremonial offerings from Ostoyahualco, the Pyramid of the Sun and the Ciudadela appear first as they are representative of the early phases, i.e. from Tzacualli to Tlamimilolpa. Next the burials and offerings excavated at the various apartment compounds and barrios of Teotihuacan are presented in chronological order. At the beginning of the discussions of each site, compound or barrio, a summary of the securely dated burials is presented first, followed by the list of unphased lots. At La Ventilla B, for example, over half the burials are in the unphased category because they were unaccompanied by ceramic vessels of any kind or accompanied by Matte miniatures exclusively, an undiagnostic ware that shows little change throughout the Teotihuacan sequence. The phasing as presented here has been revised since the first Informe that I presented to INAH (Rattray 1978).

$\underline{\text { Age and Sex Identifications: }}$

The identifications of age and sex of the human skeletal material from the compounds of La Ventilla A and B are from the study by Serrano and Lagunas (1974); Tetitla, Zacuala, Yayahuala and the Oaxaca Barrio are from studies by Spence $(1971,1974,1976,1979,1988)$ and others. Identifications of the osteological material from the Merchants' Barrio were made by Magalí Civera $(1983,1989)$ and at Tlajinga 33 by Rebecca Storey $(1985,1987)$. 
1. The Tlachinolpan, Teotihuacan site excavated by D. Blucher (1971, site 1:N7W8) is located four kilometers northwest of the Pyramid of Sun. Blucher recovered 5 burials: 3 Patlachique phase, 1 Tzacualli phase, and 1 unphased. The burials lacked offerings except Patlachique-Early Tzacualli phase Burial 3 that contained 1 Burnished olla (the burial receptacle) and 1 Thin Orange compound silhouette bowl (Rattray 1981).

2. In making up the inventories of the burials I used Cook de Leonard's (1957a) unpublished data including plans of the burials, field notes and photographs of the vessels that she kindly made available to me.

3. One of the Ostoyahualco Resist ware sherds is composed of Panuco, Veracruz paste according to neutron activation tests (Sayre and Harbottle 1979, Catalogue No. 42). Resist wares make up 7.4\% (Rattray 1973: 99-100) or 8.8\% (Smith 1987: Table 36) of the Pyramid of the Sun fill diminishing dramatically in the Late Tzacualli phase. Other than the occurrences in the Pyramid of the Sun and the Ciudadela, the ware is rare in deposits elsewhere in Teotihuacan.

4. The sample of charcoal was collected from Mound B, $8 \mathrm{~m}$. from the entrance on the upper step of the staircase for the substructure (Cook de Leonard 1971: fig. 10a) close by th burial containing a Tlaloc jar. It yielded a radiocarbon date of $1930 \pm 80$ or $28 \pm 80$ (sample Y644, Stuiver, Deevey and Gralensky 1960).

5. A radiocarbon date run on a shell artifact from one of the offerings gave a date of $1702 \pm 55$ or $243 \pm 55$ A.D. (INAH-394). In addition, two samples of human bone from Burial 190 were radiocarbon dated to $1880 \pm 60$ or $70 \pm 60$ A.D. (TO- 887 ) and $1820 \pm 60$ or $130 \pm 60$ A.D. (TO-888) by the Isotrace Laboratory of the University of Toronto (Sugiyama 1989: 97 ).

6. Charcoal from the tunnel floor gave radiocarbon dates of $400 \pm 50,340 \pm 60$ and $140 \pm 70$ A.D. (Beta Analytic Laboratory, Florida).

7. The Pueblo Perdido, San Bartolo Naucalpan, State of Mexico site, located southwest of Teotihuacan across the ancient lake has been included (Plate I) for the purpose of illustrating a complete burial assemblage of the Early Tzacualli phase. The ceramics are closely related to those of Teotihuacan.

8. This highly distinctive Lustrous ware may be the origin for one of the most characteristic Teotihuacan forms, the cylindrical tripod vase, and a whole complex of traits introduced with it, such as plano-relief decoration and the depiction of the human figure.

9. The radiocarbon test run on material from inside the incensario gave a date of $1585 \pm 50$ or 365 A.D. (Sample 1980 UCLA No. 2527B, submitted by Rattray).

10. Radiocarbon dates range between $210 \pm 60$ A.D. (OXA 935; Gowlett et al 1987) and 490 \pm 100 A.D. (OXA 884; ibid.). The OXA 935 date was run on charcoal from Late Tlamimilolpa Burial 9, Circular Structure 3. OXA date 884 was run on charcoal from Late Xolalpan Floor 4 in Squares W1S3-E1S2 at Xocotitla, Merchants' Barrio. These dates coincide well with our estimate of the occupation span of the Barrio from Late Tlamimilolpa to Late Xolalpan.

11. The Maya sherds examined by Ball (1983: 137) in 1980 came from the Teotihuacan Mapping Project surface collection and not from the Merchants' Barrio exclusively. Ball commented, "I found them to include an assortment of basal-flanged bowl, dish and jar forms representing perhaps about a dozen established types and varieties known from the southeastern through northwestern Maya lowland coastal zone." 
12. The charcoal from the burial pit yielded a radiocarbon date of $1720 \pm 65$ or $236 \pm 65$ A.D. (Linné 1956 : 191)

13. The number of Metepec burials (25) is less than one-half the number of Late Xolalpan burials (56). Late Xolalpan burials occur at La Ventilla B (11), Tetitla (10), Zacuala (9), Tlajinga 33 (9), the Merchants' Barrio (9), the Oaxaca Barrio (1), Tlamimilolpa (5), Xolalpan (4) and Yayahuala (1); Metepec burials were recovered at La Ventilla B (8), Tetitla (9), Zacuala (6) and Yayahuala (1).

14. See footnote 5 .

15. See footnote 9 .

16. It is important to know that Linné (1942) did not differentiate between stone-concrete construction and mud-adobe construction in the plans.

17. Radiocarbon determination on charcoal sample Y-1264 from Zacuala Late Tlamimilolpa-Early Xolalpan Burial 10 is $1620 \pm 80$ or $330 \pm 80$ A.D.

18. It should be made clear that Burials 1 to 26 are from Zacuala Patios; Burials 27 to 31 are from Zacuala Palace (Millon 1973: footnote 14). The locations of Burials 1-5, 10, 11, and 13 (Roman numerals on Plan 11) cited in this study, are mapped on the plan drawing of Zacuala Patios (Séjourné 1959: fig. 35). Burial 27, the "Ofrenda Palacio", was located in front of the stairway to the main entrance (fig. 28); (Séjourné 1959: fig.1). The locations of Burials 28, 29, 30 and 31 come from somewhere in the Palace, possibly the main temple. Séjourné (ibid.) does not specify exactly where Burials 6-9, 12, 14-26 come from in Zacuala Patios.

19. See footnote 17 .

20. Radiocarbon determination on charcoal sample Y-1265 from Zacuala Burial 24 is $1660 \pm 80$ or $290 \pm 80$ A.C. On stylistic grounds the burial goods have been phased as Late Xolalpan.

21. Offerings were usually made on the raising or completion of a new building, floor or wall. Such offerings are not accompanied by human bone. They are included here because they represent an important body of data for chronological studies and ceremonial practices. Also the perishability of the bone may render the two indistinguishable. 
THE TEOTIHUACAN BURIAL AND OFFERING INVENTORIES 
The Burial and Offering Inventories are presented in the following order:

The Ostoyahualco Caches

The Ostoyahualco Burials

The PuebloPerdido Burial

Pyramid of the Sun, Cave Offerings

Temple of Quetzalcoatl, Burials and Offerings

The Extroardinary Find

The Tlamimilolpa Compound Burials

The Xolalpan Compound Burials

La Ventilla A Compound Burials

La Ventilla B Compound Burials

Tetitla Compound Burials

Zacuala Palace and Zacuala Patio Burials

Yayahuala Compound Burials

The Tlajinga 33 Burials

The Oaxaca Barrio Burials

The Merchants' Barrio Burials

Proyecto Teotihuacan 1960-1964 Burials (INAH)

Proyecto Archaeological Teotihuacan 1980-1982 Burials (INAH)

The Ceramic Classification

Throughout the Commentary and Inventories the vessels and other clay artifacts are described according to the ceramic ware to which they belong (determined by paste and surface finish), and their form and decoration following the Teotihuacan Ceramic Chronology. Vessel measurements (diameter and height) are given whenever available. The Museum acquisition or field number is provided when available.

Local Teotihuacan Ware groups are:

Teotihuacan Polished Ware

Teotihuacan Burnished Ware

Teotihuacan Painted Ware

Teotihuacan Coarse Matte Ware

Teotihuacan Fine Matte Ware

Teotihuacan Dense Ware

Teotihuacan Copa Ware

Teotihuacan San Martin Orange Ware

The Foreign Wares and proveniences are:

Thin Orange Ware (Tepexi de Rodríguez, Puebla)

Granular Ware (Guerrero)

Lustrous Ware (El Tajín)

"Terrazas Lustroso" (El Tajín)

"Naranja sobre Laca Crema" (Gulf Coast)

"Rojo sobre Blanco" (Gulf Coast)

"Marfil" and "Blanco Inciso" (Gulf Coast)

Fine Paste Orange Cream and Gray (Gulf Coast)

Pre-slip Striated (Los Tuxtlas)

Coarse Striated, "Estriado" (Los Tuxtlas)

Dos Arroyos Orange Polychrome (Maya)

Cream Polychrome (Maya)

Monochrome Orange Gloss, "Aguila Orange" and Peten Gloss (Maya)

Coarse Striated Ware "Encanto Striated" (Maya) 


\section{INVENTORIES OF THE BURIALS AND OFFERINGS}

THE OSTOYAHUALCO, TEOTIHUACAN CACHES

(From Millon, Drewitt and Bennyhoff 1965)

Early Tzacualli Ostoyahualco Cache 1 (fig. 2b)

Provenience: Structure 1-D:N5W2,South Platform, Test Pit 2, below Floor 3 and on Floor 1.

$1 \quad$ Painted resist on red and yellow brown cylindrical vase with bicurvate body and everted rim Design is a possible "ojo de ave" (bird's eye). Diam. at rim $8 \mathrm{~cm}$, at base $7.5 \mathrm{~cm}$, ht. $16 \mathrm{~cm}$ (vessel 1). (Millon, Drewitt and Bennyhoff 1965: fig. 96).

1 Painted resist on red rim-shouldered bowl, interior red rim band. Diam. at rim $26 \mathrm{~cm}$, ht. $6 \mathrm{~cm}$ (vessel 2). (ibid., fig. 112)

1 Painted resist on red and yellow brown bi-pinched bowl.

1 Painted red on light brown flaring bowl. Diam. at rim approx. $23 \mathrm{~cm}$, ht. $8 \mathrm{~cm}$ (vessel 4). (ibid., fig. 116a)

1 Painted resist white and red on yellow brown flaring dish. Diam. at rim $9 \mathrm{~cm}$, ht. $4 \mathrm{~cm}$ (vessel 5). (ibid., fig. $114 \mathrm{a}$ ).

$1 \quad$ Painted resist white and red on yellow brown flaring dish (vessel 6).

$1 \quad$ Painted resist white on red and brown cylindrical vase (vessel 10).

1 Painted resist white on red and brown jar.

$1 \quad$ Painted red shouldered bowl.

$1 \quad$ Painted red on natural flaring bowl (vessel 4).

$1 \quad$ Polished shouldered black bowl (vessel 19).

1 Polished brown black compound silhouette bowl.

1 Burnished and brushed red brown olla. Diam. $32 \mathrm{~cm}$ (vessel 12).

1 Burnished "piecrust" rim red brown olla. Diam. at rim $23 \mathrm{~cm}$ (vessel 13).

$7 \quad$ Burnished and matte brushed ollas.

1 Burnished orange brown bowl.

Early Tzacualli Ostoyahualco Cache 2 (fig. 2b)

Provenience: Structure 1-D:N5W2, South Platform, Pit 2, fill of Floor 3.

1 Painted resist red and white on orange brown recurved bowl, red rimmed. Ht. approx. $10 \mathrm{~cm}$ (vessel 1). 
1 Burnished basin, orange brown exterior, brown interior, burnt (vessel 2).

$1 \quad$ Painted bichrome red and black brown flaring bowl (vessel C).

1 Painted red on orange brown flaring bowl with red rim (vessel D).

1 Burnished bevel wedge rim, orange brown olla with wiped exterior.

Early Tzacualli Ostoyahualco Cache 3 (fig. 2b)

Provenience: Structure 1-D:N5W2, South Platform, Pit 2.

$1 \quad$ Painted red on natural fluted bowl.

1 Polished groove-incised black brown bi-pinched rim bowl. Diam. at $\operatorname{rim} 8 \mathrm{~cm}$, ht. $3.5 \mathrm{~cm}$ (vessel 3). (ibid., fig. $116 \mathrm{~b}$ ).

1 Polished pale brown simple bowl with bi-pinched rim Diam. at rim $13 \mathrm{~cm}$, ht. $5 \mathrm{~cm}$ (vessel 5). (ibid., fig. $116 \mathrm{c}$ )

1 Polished black brown outcurving low vase. Diam. at rim $17 \mathrm{~cm}$, ht. $7 \mathrm{~cm}$ (vessel 4). (ibid., fig. $116 \mathrm{~d}$ )

1 Painted red bi-pinched flaring bowl with unusual staggered square design.

2 Painted resist (1) red and white on orange brown and brown, (2) red on orange brown simple bowls (vessel 12).

3 Painted resist white and red on brown bowls.

$2 \quad$ Painted resist white and red on brown jars.

Early Tzacualli Ostoyahualco Cache 4 (fig. 2b)

Provenience: Structure 1-D:N5W2, South Platform, Pit 2, below floor 3 on floor 1.

$1 \quad$ Polished flaring bowl.

$2 \quad$ Burnished and brushed ollas.

Early Tzacualli Ostoyahualco Cache 5 (fig. 2b)

Provenience: Structure 1-D:N5W2, South Platform, Pit 2, below floor 3 on floor 1.

1 Burnished brown black cajete. Diam. at rim $30 \mathrm{~cm}$, ht. $9 \mathrm{~cm}$ (vessel 2). (ibid., 1965: fig. $116 \mathrm{e})$

$1 \quad$ Painted resist white on red and brown bowl.

1 Painted resist brown and red on yellow brown shouldered bowl. 
Early Tzacualli Ostoyahualco Caches 6, 7 (fig. 2b)

Provenience: Structure 1-D:N5W2, South Platform, Pit 2.

1 Burnished orange brown wedge rim olla.

$1 \quad$ Polished fluted black brown jar.

$2 \quad$ Painted red bowls.

1 Painted red on natural shouldered bowl.

2 Painted resist red and white on orange brown bowls

\section{THE OSTOYAHUALCO, TEOTIHUACAN BURIALS}

(Cook de Leonard 1957a)

Early Tzacualli Ostoyahualco Burials 1 and 2 (fig. 2b)

2 adults (1 male), crania and long bones.

Provenience: Near entrance of tunnel into Temple Platform B, Plaza I, Ostoyahualco (Site 1:N5W2).

1 Tlaloc florero, pastillaje technique, covered with ochre. Diam. at rim $8.5 \mathrm{~cm}$, body 7.5 cm, ht. 9.5 cm (Plate II; Cook de Leonard 1971, fig. 10a).

1 Polished black incised jar.

1 Pearl.

$1 \quad$ Flint knife with red and white paint.

Early Tzacualli Ostoyahualco Burial 3

Age-sex unknown.

Provenience: Tunnel into Temple Platform B, Plaza I, Ostoyahualco.

1 Polished vessel with motif of incised circles.

1 Obsidian knife. 
Early Tzacualli Ostoyahualco Burial 4 (fig. 2b)

No bones reported.

Provenience: Tunnel in Temple Platform B, Plaza I.

1 Polished Tlaloc florero (frag.).

1 Obsidian knife, red and black banded.

Early Tzacualli Ostoyahualco Burial 5 (fig. 2b)

Age-sex unknown.

Provenience: Tunnel in Temple Platform B, Plaza I.

1 Black Tlaloc jar in fragments.

3 Ceramic vessels.

1 Obsidian scraper.

1 Obsidian knife.

Early Tzacualli Ostoyahualco Burial 6 (fig. 2b)

1 Adult, primary.

Provenience: Tunnel in Temple Platform B, Plaza I.

1 Low Polished Tlaloc florero, dark gray, with features done in pastillaje technique (yellow deposit on body). Diam. at rim $8 \mathrm{~cm}$, globular body $7 \mathrm{~cm}$, ht. $9 \mathrm{~cm}$

1 Obsidian knife.

Cloth fiber, burnt and decomposed

Early Tzacualli Ostoyahualco Burial 7 and Burial 12 (fig. 2b)

Provenience: Tunnel in Temple Platform B, Plaza I.

No data.

Early Tzacualli Ostoyahualco Burial 8-8a

1 Adult, wrapped in cloth.

Provenience: Tunnel in Temple Platform B, Plaza I.

1 broken vessel.

$1 \quad$ jade disk. 
Early Tzacualli Ostoyahualco Burial 9 (fig. 2b)

Age-sex unknown, primary.

Provenience: Tunnel in Temple Platform B, Plaza I.

No offering recorded.

Early Tzacaualli Ostoyahualco Burial 10 (fig. 2b)

1 Adult, primary.

Provenience: Tunnel in Temple Platform B, Plaza I.

1 Tlaloc vase coated with ochre.

$1 \quad$ Mosaic pectoral (jadeite?).

$1 \quad$ Perforated disk.

Red pigment.

Early Tzacualli Ostoyahualco Burial 11 (fig. 2b)

2 Adults: 1 flexed primary wrapped in cotton cloth or ixtle; 1 secondary.

Provenience: Tunnel in Temple Platform B, Plaza I, Ostoyahualco.

$1 \quad$ "Zacatenco III" tricolor style vessel.

Isolated Offerings:

1 Necklace of human molars and "bone imitation thereof arranged to represent a corncob". (Cook de Leonard 1957a).

1 Stone frog sculpture with red pigment.

\section{AZCAPOTZALCO: PUEBLO PERDIDO OFFERING \\ (From Rattray 1968)}

Early Tzacualli Puebo Perdido Burial 1 (Plate 1)

Adult, sex unknown.

Provenience: Under stone platform below packed earth floor 1

1 Foreign Glossy Orange upright bowl. Diam. at rim $13 \mathrm{~cm}$, ht. $4 \mathrm{~cm}$ (Plate 1a).

1 Polished flaring rim florero with bosses around body and parallel incisions on neck. Diam. body $7 \mathrm{~cm}$, ht. $10 \mathrm{~cm}$ (Plate $1 \mathrm{~b}$ ).

$1 \quad$ Painted red exterior and rim, brown bowl (Plate 1c). 
1 Polished (poorly), simple brown bowl. Diam. at rim $15 \mathrm{~cm}$ (Plate 1d).

1 Polished red rim on brown miniature bowl. Diam. at rim $9 \mathrm{~cm}$ (Plate 1e).

1 Polished black rim shouldered bowl. Diam. at rim $13.5 \mathrm{~cm}$, ht. $3.5 \mathrm{~cm}$ (Plate 1f).

\section{PYRAMID OF THE SUN: CAVE OFFERINGS. (INAH 1971 Excavations)}

Late Tzacualli Cave Offering (INAH excavations by Acosta, 1971, described by Heyden 1975, p 131)

Provenience: Cave-tunnel with entrance at the foot of main stairway to the Pyramid of the Sun. Offering in cloverleaf chamber.

1 Stone disk with carving of human figure wearing a bird headdress with Tajín style volutes forming the background (Heyden 1975, fig. 2).

1 Stone disk with carving of a man wearing a jaguar headdress (ibid.,fig. 3).

Several flaring wedge rim, globular bodied jars, probably matte finished (ibid., fig. 3).

Late Tzacualli Cave Offerings: (Millon 1981)

Stratigraphic pit excavations of Acosta tunnel by Millon (ibid., 233-235)

Provenience: Firepit near center of cave.

Iridescent shells.

Large quantities of fish bones.

Matte wedge rim jars. Diam. at $\operatorname{rim} 14 \mathrm{~cm}$, body $16 \mathrm{~cm}$, ht. $19 \mathrm{~cm}$

Polished low-walled plates. Average diam. $15 \mathrm{~cm}$

Polished floreros. Diam. at rim approx. $10 \mathrm{~cm}$

\section{CIUDADELA: TEMPLE OF QUETZALCOATL BURIALS AND OFFERINGS}

Early Tlamimilolpa "Ofrenda I" (Inventory from Rubín de La Borbolla 1947:68-69).

Human teeth with dental mutilation and pyrite incrustations

Provenience: Front of steps Temple of Quetzalcoatl, "Old Temple" (fig.2c).

Obsidian bifaces (points and knives, finely worked). 
Obsidian anthropomorphic and zoomorphic figurines.

Clay figurines and animal figurines (14 illustrated).

Jade beads, anthropomorphic figurines, ear ornaments, 3 to $13 \mathrm{~cm}$ in diam.

(15 illustrated).

Unworked jade.

Worked shell, beads, disks and mosaics.

Perforated and cut shells (Oliva angulata Lamark, Oliva Porphyria Linnaeus).

Carved conch shells (Fasciolaria gigantea).

Bone needles.

Pyrite disks ( $23 \mathrm{~cm}$ to $12 \mathrm{~mm}$ in diameter).

Animal bones (deer, rabbit, coyote).

Yellow pigment.

Painted slate.

Early Tlamimilolpa Offering 1 (Same as "Ofrenda 1")

(Inventory from Sugiyama 1986: fig. 30)

No bones reported; one human tooth with incrustation.

Provenience: Front of stairway "Templo Viejo de Quetzalcoatl", at depth $60 \mathrm{~cm}$, "Pit 1 of Perez".

Obsidian artifacts: 140 projectile points, 5 small knives, 3 frag. knives, 135 prismatic blades, 22 human figures, 3 serpent figures

Jade and jadeite artifacts: 14 small beads, 1 small ear ornament, 2 small amulets

Shell and Snail artifacts: 35 small shells, perforated; 1 small shell disk, perforated;

1 large engraved spiral shell; 2 medium spiral shells; 1 small snail shell; 70 snail frag.

Slate: 6 frag. with red paint

Ceramic objects: frag. of figurines

1 Animal fang 
Early Tlamimilolpa Offering 1

(From inventory Sugiyama 1986:fig. 30; 1989, Table 3)

Provenience: "Templo Viejo de Quetzalcoatl" (Extension of Pérez Pit to $70 \mathrm{~cm}$ )

Obsidian: 35 projectile points; 19 small knives; 10 frag. of knives; 17 prismatic blades; 162 frag. blades; 5 human figures; 1 serpent figure

Jade and jadeite: 25 small beads 5 frag. beads; 5 ear ornaments; 3 figurines lacking ears; 3 small amulets

Shell and Snail: 2 small shells, perforated; 14 frag. shell and snail, 1 large caracol, 26 small snails

1 Shell mosaic

Pyrite: 1 small disk

Ceramic: 1 figurine

Yellow clay: 2 frag.

Burial "New Temple", Tunnel

Human cranium, fragment

Provenience: New Temple,Tunnel interior, "Pit 2 of Pérez", (Inventory Sugiyama 1986: fig. 30; 1989, Table 3)

Obsidian: blades, knives, punches; 63 pieces knives, human figurine, serpent figure, punches.

Jade or jadeite: 7 beads, 2 ear ornaments, figurines, small figurines with ears, pieces of headdresses, pieces of unworked jade

Shell and Snail: 1 shell, shells with perforations, mosaics, 1 snail, snails

Pyrite: 1 Disk with perforation

Bone: animal bones

Bone needles and spatula

Yellow pigment

Burial 1, west side, (Miccaotli- Early Tlamimilolpa)

1 Isolated cranium with mandible

Provenience: Upper central part of the Temple of Quetzalcoatl (Sugiyama1989, Table 3)

Jade and jadeite: 145 small beads, 13 large beads, 2 long beads, 8 ear ornaments with rose color paint, 2 disks, 1 small disk, 1 head 
Shells: 2 large shells, large quantity of small shells

Pyrite: 5 disks

Slate: 1 piece with red motif

Ceramic: 1 Tlaloc jar with twisted handle, ht. $2.5 \mathrm{~cm} ; 2$ ollas

Burial 1, East side (Miccaotli-Early Tlamimilolpa )

1 Cranium, mandible, vertebrae, long bones ribs

Provenience: Upper part of Old Temple of Quetzalcoatl (ibid., Table 3)

Obsidian: 11 knives

Jade and jadeite: 84 small beads, 14 large beads, 1 large bead, 4 ear ornaments, 2 disks, 1 small disk, 1 head

Shell: 2 shells with perforation, 2 small shells

Slate: 5 disks

Copal: 1 fragment

Ceramic: 1 Tlaloc jar, ht. $2.5 \mathrm{~cm}$

Burial 2, East side (Miccaotli-Early Tlamimilolpa )

1 or 2 individuals (not specified)

Provenience:Upper central part of Old Temple of Quetzalcoatl (ibid., Table 3)

Obsidian: 1 knife

Jade and jadeite: 50 small beads; 27 large beads, 1 long bead, 2 ear ornaments

Ceramic: 2 Tlaloc jars; 5 small bowls

Burial 2, West side ( Miccaotli-Early Tlamimilolpa)

Provenience: Upper part of Old Temple of Quetzalcoatl (ibid., Table 3)

Jade or jadeite: 29 small beads, 1 long bead, 2 large ear ornaments, 2 small ear ornaments, 1 ear ornament with back, 1 broken ear ornament, 1 small disk, 2 heads,

1 "charm" nose plug?

Shell: 4 large, 9 small

Pyrite: 10 disks

Clay, charcoal, copal 
Burial 3 (Miccaotli-Early Tlamimilolpa, (Inventory from Sugiyama 1986: fig. 30; 1989, Table 3)

2 individuals, 1 cranium with mandible, vertebrae, long bones

Provenience: Upper central part of Temple of Quetzalcoatl

Obsidian: 1 projectile point, 4 knives

Jade and jadeite: 32 beads, 2 ear ornaments, 2 small ear ornaments, 1 head, 2 "charm" nose plugs?

Shell: small shells

Ceramics: 5 small bowls with copal and clay

2 limestone disks

Clay, charcoal

\section{OFFERINGS AND BURIALS, SOUTH SIDE OF TEMPLE OF QUETZALCOATL}

(Proyecto Arqueológico Teotihuacan 80-82)

Burial 203 Miccaotli-Early Tlamimilolpa (Sugiyama 1986: fig. 30; 1989, Table 3)

1 Young adult, male

Provenience: Burial pit below south central side of Temple of Quetzalcoatl (fig. 2c)

$9 \quad$ Obsidian projectile points

1 Obsidian blade

21 Jade beads, small

2 Jade ear ornaments

$1 \quad$ Jade nose plug

Burial 190 Miccaotli-Early Tlamimilolpa (fig.4; Sugiyama 1986, Fig. 30; 1989: fig. 5, Table 3) ${ }^{\text {s }}$

18 males (7 Sub-adults, 5 young adults, 6 mature adults)

Provenience: Large burial pit, below south facade, Temple of Quetzalcoatl (fig. 2c)

169 Gray Obsidian projectile points

5 Obsidian blades

Shell Objects: 1,208 beads, 1,562 pendants, 1,588 misc. pieces

16 Pyrite disks (identified as back ornaments, tezcacui-tlapilli). 
Associated material: 4 pendants. Imitations in shell of maxilla and mandibles.

Worked human bone: 4 mandibles, 14 maxillas

Burial 153 Miccaotli-Early Tlamimilolpa (Sugiyama 1986, Fig. 30; 1989, Table 3)

1 Young Female

Provenience: Burial pit below south central facade, Temple of Quetzalcoatl (fig. 2c)

1,606 worked caracol shells

\section{TLAMIMILOLPA COMPOUND: LATE TLAMIMILOLPA BURIALS}

Late Tlamimilolpa Burial 1

1 Adult (incineration).

Provenience: Tlamimilolpa Compound, Room 16, northeast corner under Floor 3 in tomb-like chamber (fig. 22; Linné 1942).

115 Painted red on brown thick-walled, small everted rim cylindrical vases with nubbin supports. Diam. at rim $5.3 \mathrm{~cm}$ to $7.1 \mathrm{~cm}$, ht. $4.7 \mathrm{~cm}$ to $5.9 \mathrm{~cm}$ (ibid., fig. 212).

2 Painted red on brown everted rim cylindrical vases with nubbin supports.

Ht. $7 \mathrm{~cm}, 7.6 \mathrm{~cm}$

$4 \quad$ Painted red on natural everted rim cylindrical vases, incised motifs with white paint (ibid., figs. 206, 207, 209, 210).

2 Polished and incised everted rim cylindrical vases, incised motifs with white paint (ibid., fig. 208).

2 Polished brown everted rim small vases with nubbins (ibid., fig. 222).

2 Polished brown cylindrical vases with hollow round supports coated with cinnabar (ibid., fig. 201).

1 Polished brown cylindrical vase with basal flange and hollow rectangular supports.

$1 \quad$ Polished and incised cylindrical vase.

1 Polished and incised cylindrical vase with simple and incised geometric motifs.

Diam. ca. $20 \mathrm{~cm}$, ht. $8.5 \mathrm{~cm}$

1 Polished cylindrical vase with hollow rectangular, cutout supports.

5 Polished flaring walled cylindrical tripods with large hollow rectangular supports.

$8 \quad$ Polished vase lids with plain knobs. 
1 Polished vase lid, overhang decorated with split disk adornos and coated with cinnabar.

3 Polished low-walled bowls with conical supports. Diam. $4.6 \mathrm{~cm}$ to $6.1 \mathrm{~cm}$ (ibid., fig. 226).

4 Polished gadrooned/incised jars with upright rims and nubbin supports (ibid., fig. 213).

$4 \quad$ Polished jars with upright rims and nubbin supports.

8 Polished, handled lids (ibid., fig. 213).

3 Fine Matte handled cover-plates. Diam. at rim $16.8 \mathrm{~cm}$ to $17.2 \mathrm{~cm}$ (ibid., fig. 221).

2 Coarse Matte 3-prong censers (ibid., fig. 218).

$4 \quad$ Polished copas with spouts. Ht. $11.1 \mathrm{~cm}$ to $11.9 \mathrm{~cm}$ (ibid., fig. 211).

13 Polished floreros. Ht. $5.0 \mathrm{~cm}$ to $6.1 \mathrm{~cm}$ and 9 to $9.9 \mathrm{~cm}$

1 Polished miniature florero (ibid., fig. 214).

17 Polished dark brown low-walled plates. Diam. $6 \mathrm{~cm}$ to $17.1 \mathrm{~cm}$ (ibid., fig. 225 to 229).

4 Burnished jars (antaros) (ibid., fig. 200).

1 Coarse Matte incensario (80 fragments).

10 Pieces mica, cylindrical shape. Diam. $2.9 \mathrm{~cm}$ to $3 \mathrm{~cm}$

1 Polished pyrite mirror. Diam. $6 \mathrm{~cm}$

1 Pyrite ball (ibid., fig. 236).

$1 \quad$ Pyrite "eye" from face mask.

2 Bone awls.

1 Bone ornament with perforation (ibid., fig. 249).

1 Animal incisor, perforated.

8 Shell ornaments.

Large number marine shells

Charred textiles, baskets

Fragments resembling metal

Slate pieces 
Late Tlamimilolpa Burial 5

1 Adult male.

Provenience: Tlamimilolpa, Room 38, Stage III (below $2 \mathrm{~m}$ of fill) (fig. 22; Linné 1942: 135-136).

1 Polished black jar with nubbin supports. Ht. $8.3 \mathrm{~cm}$ (ibid., fig. 256)

2 Polished outcurving bowls with "vestigial" nubbins (1) Polished black, diam $15.6 \mathrm{~cm}$, (2) $10.3 \mathrm{~cm}$

1 Polished cylindrical vase with nubbin supports. Diam. $7.6 \mathrm{~cm}$, ht. $4.6 \mathrm{~cm}$

2 Fine Matte miniature jars coated with red pigment.

12 Fine Matte miniature ollitas.

$1 \quad$ Bone awl, length $13.8 \mathrm{~cm}$

$1 \quad$ Bone needle.

1 Stone bead.

$1 \quad$ Piece slate.

3 Mica slabs.

6 Mica flakes.

1 Obsidian lanceolate knife, length $19 \mathrm{~cm}$ (ibid., fig. 271).

3 Obsidian knives, (lengths $6.3 \mathrm{~cm}, 5.8 \mathrm{~cm}, 4.7 \mathrm{~cm}$ ).

9 Obsidian points, largest $5.7 \mathrm{~cm}$ to $7.1 \mathrm{~cm}$, smallest $3.1 \mathrm{~cm}$ to $2.2 \mathrm{~cm}$ (ibid., figs. 265, 266).

2 Shell ornaments.

Pieces of slate

Copal

Shells

Late Tlamimilolpa Burial 7

Perinatal.

Provenience: Tlamimilolpa, Room 107 (fig. 22; Linné 1942: 136).

1 Polished outcurving bowl with nubbin supports. Diam. $27.8 \mathrm{~cm}$, ht. $5.4 \mathrm{~cm}$

$1 \quad$ Worked stone inside bowl. 


\section{EARLY XOLALPAN BURIALS}

\section{Early Xolalpan Burial 9}

1 Perinatal

Provenience: Tlamimilolpa, Room 10, Stage III (fig. 22; Linné 1942: 137).

2 Polished outcurving bowls. Diam. 23 to $26 \mathrm{~cm}$ (ibid., figs. 203, 217).

$1 \quad$ Piece slate.

1 Obsidian knife.

\section{Early Xolalpan Burial 10}

1 Perinatal

Provenience: Tlamimilolpa, Room 10, Stage III (fig. 22; ibid., 137).

1 Polished outcurving bowl with nubbin supports.

\section{Early Xolalpan Burial 11}

Perinatal.

Provenience: Tlamimilolpa, Room 50, Stage III (fig. 22; ibid., p. 138).

5 Polished brown-black outcurving bowls. Diam. 20 to $20.9 \mathrm{~cm}$ (ibid., figd. 203, 217).

3 Polished brown-black outcurving bowls.

\section{TLAMIMILOLPA COMPOUND: LATE XOLALPAN BURIALS}

Late Xolalpan Burial 4

1 Adult male

Provenience: Tlamimilolpa, Room 1, Stage II (fig. 222; Linné 1942: 134)

1 Resist on Red Painted cylindrical vase (yellow pigment inside). Ht. $8.2 \mathrm{~cm}$ (Probable Copa ware).

2 Polished outcurving bowls: (1) Diam. $13.9 \mathrm{~cm}$, (2) $16.3 \mathrm{~cm}$ (ibid.,fig. 203, 217).

1 Fine Matte miniature jar. Ht. $4.5 \mathrm{~cm}$ (ibid., fig. 278).

1 Polished wide mouth jar with pattern polish neck and body. Ht. $12.6 \mathrm{~cm}$ (similar to ibid., fig. 256).

1 Painted red on natural jar with conical body and restricted neck (ht. $11.2 \mathrm{~cm}$ ). 
1 Polished brownish red simple bowl. Diam. $12.5 \mathrm{~cm}$, ht. $7.2 \mathrm{~cm}$

1 Bone needle.

2 Obsidian figurines.

2 Obsidian knives: (1) lanceolate, length $13.5 \mathrm{~cm}$ (ibid., fig. 270), (2) (ibid., fig. 271).

1 Obsidian point. Length $8.2 \mathrm{~cm}$

3 Obsidian tools (ibid., fig. 267-269).

$2 \quad$ Ear plugs $(2.8$ and $3 \mathrm{~cm})$.

Fresh water shells

\section{Late Xolalpan Burial 13}

1 Aged individual

Provenience: Tlamimilolpa, Room 6, below floor (fig. 22, Burial excavated by proprietor) (Linné 1942: p.139).

2 Stucco painted cylindrical vases. Diam. at rim $23.8 \mathrm{~cm}$

$1 \quad$ Polished upright neck jar with globular supports.

$1 \quad$ Polished widemouth jar. Ht.9.3 cm

1 Thin Orange bvowl, incised and punctate $\mathrm{S}$ motif. Diam. $23.3 \mathrm{~cm}$, ht. $9.6 \mathrm{~cm}$

2 Polished bowls. Diam. $6.3 \mathrm{~cm}, 10.1 \mathrm{~cm}$

17 Matte miniature plates. Diam.6.3 cm to $4.7 \mathrm{~cm}$

18 Matte miniature ollitas.

2 Shell rings.

1 Mother of pearl ornament.

1 Clay stamp.

1 Clay vase adorno (mussel).

$2 \quad$ Large puppet figurines.

1 Onyx bowl.

1 Stone ornament (light green).

1 Jade bead. 


\section{Metepec Burial 2}

1 Young adult.

Provenience: Tlamimilolpa, Room 22, Stage II (fig. 22; Linné 1942:132-133).

2 Polished widemouth jars with pattern-polished necks and zone polished circular motifs on globular body (ibid., fig. 256).

3 Polished outcurving bowls. Diam. at rim $12.1 \mathrm{~cm}, 16.2 \mathrm{~cm}, 23.7 \mathrm{~cm}$

3 Thin Orange ring base bowls with incised S-motifs, lines and dots (ibid., fig. 299).

1 Matte ware plate, crude. Diam. at rim $12.1 \mathrm{~cm}$

3 Fine Matte miniature bowls: (1) dimpled base, diam. at rim $7.2 \mathrm{~cm}$ (2) flat bottom straight-sided bowl, diam. at rim $5.2 \mathrm{~cm}$ (3) flat bottom straight-sided bowl, diam. $6.9 \mathrm{~cm}$

1 Fine Matte miniature jar. Ht. $3.6 \mathrm{~cm}$ (ibid., fig.278).

1 Clay figurine, moldmade (ibid., fig. 257).

$1 \quad$ Stone bead (ibid., fig. 258).

1 Lava stone bowl (ibid., fig. 260).

8 Shell pendants (ibid., fig. 259).

1 Bone needle (ibid., fig. 261).

1 Bone awl (ibid., fig. 262).

\section{UNPHASED BURIALS: TLAMIMILOLPA COMPOUND}

\section{Unphased Burial 3}

\section{Age-sex unknown}

Provenience: Tlamimilolpa, Room 91 (fig. 22; Linné 1942: 134).

1 Polished human effigy with lid, (head missing) (ibid., fig. 197).

\section{Unphased Burial 6}

1 Perinatal.

Provenience: Tlamimilolpa, Room 109 (fig. 22; ibid., p. 136).

4 Clay beads 
Unphased Burial 8

1 Perinatal

Provenience: Tlamimilolpa, Room 96 (fig. 22; ibid., p. 136)

Large Burnished Olla (fragment)

2 Obsidian knives, lengths $6.3 \mathrm{~cm}$ and $9 \mathrm{~cm}$

1 Clay spindle whorl, conical (Diam. $1.6 \mathrm{~cm}$ ).

\section{Unphased Burial 12}

1 Perinatal

Provenience: Room 49 (fig. 22; ibid., p. 138).

7 Matte miniature plates. Diam. $4 \mathrm{~cm}-4.6 \mathrm{~cm}$

2 Matte miniature bowls. Diam. $1.7 \mathrm{~cm}-2.3 \mathrm{~cm}$

$1 \quad$ Obsidian knife.

Mica flakes

1 stone painted white

TLAMIMILOLPA COMPOUND: CACHES OR OFFERINGS

Late Tlamimilolpa Cache 2

Provenience: Tlamimilolpa, Room 27, "middle" floor (fig. 22; ibid., p. 143).

1 Polished rounded base jar with groove-incised body. Diam. $5.5 \mathrm{~cm}$, ht. $5.1 \mathrm{~cm}$

3 Polished widemouth jars with groove-incised bodies and flaring rims. Diam. $5.5 \mathrm{~cm}$, $7.5 \mathrm{~cm}, 8.2 \mathrm{~cm}$

1 Polished cylindrical vase with hollow cylindrical supports. Diam. $7.1 \mathrm{~cm}$, ht. $6.7 \mathrm{~cm}$

1 Polished flaring cylindrical vase with nubbin supports and incised decoration. Diam. $8.6 \mathrm{~cm}$, ht. $7.1 \mathrm{~cm}$

2 Polished floreros. Ht. $11.2 \mathrm{~cm}$ and $13 \mathrm{~cm}$ 
Late Xolalpan Cache 1

Provenience: Tlamimilolpa, Room 3, in shaft originating on Floor 2 (fig. 22; ibid., p. 142).

1 Coarse Matte incensario with 2-part censer base, face mask (ibid., Plates 3-5).

2 Copa ware cylindrical vases with large "Fat God" head appliqué on body, coated with red pigment.

4 Polished black-brown outcurving bowls with nubbin supports (ibid., fig. 288).

1 Obsidian ring.

1 Bone needle, $20 \mathrm{~cm}$ long.

1 Bone needle.

4 shells.

Metepec Cache 3

Provenience: Tlamimilolpa, Passageway between Rooms 94 and 95 (fig. 22; ibid., 143).

1 Burnished olla with ovoid body and low rounded rim Diam. $50 \mathrm{~cm}$, ht. $58 \mathrm{~cm}$

$1 \quad$ Polished outcurving bowl with nubbin supports.

TLAMIMILOLPA COMPOUND BURIALS: 1983 EXCAVATIONS

(Rattray 1984, 1989)

Early Xolalpan Burial 1-83

1 Adult, partially incinerated.

Provenience: Tlamimilolpa Compound, Northeast corner, Room 56 (fig. 23).

1 Polished vase with rounded basal flange and bud-like supports. Diam. at rim $13 \mathrm{~cm}$, at base $11.5 \mathrm{~cm}$, ht. $11.5 \mathrm{~cm}$

1 Polished brown-black wide mouth jar. Diam. at rim $15.5 \mathrm{~cm}$, at base $8 \mathrm{~cm}$, ht. $12.5 \mathrm{~cm}$

1 Polished black outcurving bowl. Diam. at rim $31 \mathrm{~cm}$, at base $19 \mathrm{~cm}$, ht. $6 \mathrm{~cm}$

1 Polished outcurving bowl with vestigial nubbins. Diam. at rim $17 \mathrm{~cm}$, at base $11 \mathrm{~cm}$, ht. $3.5 \mathrm{~cm}$

1 Polished lustrous brown outcurving bowl with postfire incised flower design on inside bottom. Diam. at rim $16.5 \mathrm{~cm}$, at base $11.5 \mathrm{~cm}$, ht. $5 \mathrm{~cm}$ 
Slate fragments

Mica flakes

Carbon

\section{Early Xolalpan Burial 2-83}

1 Adult.

Provenience: Tlamimilolpa, Room 15, Looter's Pit (fig. 23).

2 Fine Matte ollitas.

1-2 Incensarios (parts of face mask, censer cone, appliqued collar, hand).

3 Feathered disks and plaques with yellow pigment.

1 Candelero.

Mica flakes.

Polished outcurving bowls (fragments).

Carbon.

Late Xolalpan Burial 3-83

1 Perinatal.

Provenience: Tlamimilolpa, Northeast corner, Room 15 (fig.23).

1 Polished outcurving bowl with obtuse base angle. Diam. at rim $22.5 \mathrm{~cm}$, at base $14.5 \mathrm{~cm}$, ht. $3.5 \mathrm{~cm}$

Late Xolalpan Burial 4-83

1 Perinatal

Provenience: Southeast corner of Room 15 (fig. 23).

1 Polished light brown outcurving bowl. Diam. at rim $25 \mathrm{~cm}$, at base $14.5 \mathrm{~cm}$, ht $5 \mathrm{~cm}$

Late Xolalpan Burial 5-83

1 Perinatal.

Provenience: South wall of Room 15 (fig. 23).

1 Polished outcurving bowl. Diam. at rim $22 \mathrm{~cm}$, at base $14 \mathrm{~cm}$, ht $3.5 \mathrm{~cm}$

1 Polished pale brown outcurving bowl. Diam. at rim $25 \mathrm{~cm}$, at base $15 \mathrm{~cm}$, ht $5 \mathrm{~cm}$ 


\section{BURIALS FROM THE XOLALPAN COMPOUND}

(From Linné 1934)

\section{Early Xolalpan Burial 1}

1 Adult of advanced age.

Provenience: Xolalpan Compound, Under Room VII, tomb-like structure (fig. 30; Linné 1934, p. 54).

1 Polished cylindrical vase with matching lid, plano relief decoration, Tlaloc figures. Estimated size: diam. $18 \mathrm{~cm}$; ht. $16 \mathrm{~cm}$ (incl.supports); lid diam. $20 \mathrm{~cm}$ (ibid., fig. 21, 21A).

1 Polished cylindrical vase, plano-relief decoration, geometric motifs (ibid., fig. 22).

2 Polished vases with plano-relief geometric motifs (ibid., fig. 24).

2 Polished vases, elaborate plano-relief decoration, vermillion paint rubbed into abraded areas (ibid., fig. 25A).

$1 \quad$ Copa ware vase with negative resist motifs.

1 Polished outcurving bowl, red pigment on interior.

Several small clay dishes (probably matte miniatures).

1 Obsidian biface, laurel leaf (ibid., fig. 309).

1 Obsidian spear point (ibid., fig. 297).

3 Obsidian anthropomorphic figures, small and flat (ibid., figs. 315-317).

1 Stone celt (ibid., fig. 255).

\section{Early Xolalpan Burial 2}

1 Adult's tooth

Provenience: Xolalpan Compound, Room XV, under floor

(fig. 30; ibid., p. 59, fig. 9).

2 Polished cylindrical vases with hollow rectangular supports and bird knobs on lids. Plano relief decoration, the abraded areas filled with vermillion paint (ibid., fig. 28 and 29).

1 Polished cylindrical vase with 3 Tlaloc figures executed in plano relief technique (ibid., figs. 26, 26A).

1 Polished cylindrical vase with geometric design and hollow rectangular supports. 
$1 \quad$ Polished undecorated vase without supports.

3 Candeleros: 2 one-holed; 1 two holed.

3 Polished dishes: 1 with stick-polished bottom; 1 coated in red hematite; 1 plain with nubbin supports.

3 Matte wide mouth jars.

2 Jars.

1 Clay figurine body (ibid., fig. 30).

\section{Late Xolalpan Burial 3}

Possible incineration.

Provenience: Xolalpan Compound, $1.45 \mathrm{~m}$ below floor, southeast corner of Room XVI (fig. 30).

1 Polished crude Tlaloc jar (ibid., fig. 34).

1 Polished "Tlaloc" head fragment.

1 Stucco Painted red, green and black cylindrical vase with rounded basal torus and hollow cylindrical supports. Butterfly and lattice work motifs. Matching lid (ibid., fig. 36).

1 Polished cylindrical vase with incised motifs and traces of stucco paint (ibid., fig. 33).

1 Polished cylindrical vase with molded adornos (heads) around basal flange (ibid., fig. 35).

1 Polished plano relief decorated vase with red pigment in excised areas (ibid., fig. 38).

1 Polished undecorated cylindrical vase without supports.

1 Copa ware vase, lower half painted red (ibid., fig. 39).

$5 \quad$ Thin Orange bowls.

1 Polished orange bowl (imitation Thin Orange).

2 Polished widemouth jar.

1 Light brown saucer with nubbin supports.

2 Polished outcurving bowls with rudimentary nubbins.

$2 \quad$ Matte miniature plates. 
2 Candeleros.

Mica flakes.

Late Xolalpan Burial 4

Age-sex unknown

Provenience: Xolalpan Compound, Courtyard outside eastern wall Room VII

(fig. 30; ibid., p 68).

1 Polished plano relief cylindrical vase with "symbolic" designs (ibid., fig. 41).

10 Thin Orange bowls with ring bases, diam. largest $26 \mathrm{~cm}$ (3 incised and punctate decoration, ibid., figs. 43- 45; 1 corrugated flaring bowl, fig. 46).

1 Copa Ware vase (ibid., fig. 48).

1 Tlaloc jar (ibid., fig. 40).

1 Polished gadrooned jar with rounded bottom (ibid., fig. 47).

1 Polished jar with globular supports (ibid., fig. 42).

6 Polished bowls.

2 Polished outcurving bowls.

$7 \quad$ Matte miniature bowls with dimpled bases.

$8 \quad$ Matte miniature widemouth jars.

1 Painted Matte miniature vase with thick walls.

1 Matte round object, possible adorno.

9 Candeleros: 8 one-chambered: 1 two-chambered.

10 Mica disks.

\section{Late Xolalpan-Metepec Burial 5}

1 Adult, middle aged male

Provenience: Xolalpan Compound, Below floor Room II, latest construction (fig. 30; ibid., p 71).

$5 \quad$ Polished brown outcurving bowls.

1 Painted specular red on brown outcurving bowl. 
1 Thin Orange bowl with ring base.

$1 \quad$ Matte miniature widemouth jar.

Late Xolalpan-Metepec Burial 6

Perinatal.

Provenience: Xolalpan Compound, East wall of Room II (fig. 30).

2 Polished outcurving bowl (ibid., figs. 50, 53).

1 Thin Orange bowl.

1 Coarse Matte censer bowl with wide rim flange (burial receptacle) (ibid., figs. 49, 49A).

$1 \quad$ Flaring bowl (cover for censer) (ibid., fig. 49).

1 Polished jar with short neck (ibid., fig 49A).

Late Xolalpan-Metepec Burial 7

1 Perinatal.

Provenience: Xolalpan Compound, East wall of Room II (ibid., p. 72)

1 Painted red on brown outcurving bowl with nubbin supports.

1 Thin Orange bowl with ring base and incised decoration (burial receptacle).

2 Polished outcurving bowls.

1 Polished miniature jar with upright rim

"THE EXTRAORDINARY FIND"--LATE TLAMIMILOLPA PHASE

(From Noguera 1955)

Child, sex unknown

Provenience: North of San Juan River, east of Street of the Dead. Below concrete floor at 1.83 cm depth. (ibid., fig. 1).

1 Polished black incised cylindrical vase with hollow round supports. Approx. diam. at rim $15 \mathrm{~cm}$ (ibid., fig. 3b).

1 Polished black cylindrical vase with hollow rounded supports. Approx. diam. at rim, $12 \mathrm{~cm}$ (ibid., fig. 3c).

1 Polished black cylindrical vase with basal molding, hollow cylindrical supports.

Approx. diam. at rim $11 \mathrm{~cm}$ (ibid., fig. 3a). 
1 Polished globular fluted jar with upright rim, basal molding with inset "coffee bean" adornos MNA No. 9-2488 (ibid., fig. 4)

1 Lustrous ware cylindrical vase with rounded basal flange, hollow cylindrical supports, apron lid with knob. Simple geometric incised designs. Diam. at rim $19.5 \mathrm{~cm}$, ht. 16.8 $\mathrm{cm}$, ht. with lid $23 \mathrm{~cm}$ MNA 9-135A. (ibid., fig. 14).

1 Lustrous ware cylindrical vase with hollow rectangular supports and lid, plano-relief decoration in "Totonac Scroll" and cinnabar. Diam. at rim $23 \mathrm{~cm}$, ht. $19.5 \mathrm{~cm}$, ht. with lid $27.5 \mathrm{~cm}$ (ibid., fig. 13) (Plate XII).

1 Lustrous ware (possible) vase with hollow rectangular supports and lid. Decoration consists of onyx incrustations covering entire vessel and lid, coated in cinnabar. Diam. $17.7 \mathrm{~cm}$, ht $15 \mathrm{~cm}$, ht. with lid $23.3 \mathrm{~cm}$ (ibid., fig. 15).

6 Polished black copas with broad pedestal bases. Approx. diam. $5 \mathrm{~cm}$, ht. $10 \mathrm{~cm}$, smallest $8 \mathrm{~cm}$ (ibid., fig. 5).

1 Polished pale brown incised jar, basal flange, globular body and flaring rim Diam. 13 $\mathrm{cm}$, ht. $14 \mathrm{~cm}$, maximum width $15 \mathrm{~cm}$ (ibid.,fig. 6, lid shown in fig. 7).

1 Painted red and natural upright bowl with everted lip. Diam. $10 \mathrm{~cm}$, ht. $3.5 \mathrm{~cm}$ (ibid.,fig.8).

4 Polished upright bowls in various sizes (ibid., fig. 9).

2 Candeleros with punctate decoration (ibid., fig. 10).

1 Stone miniature metate and mano (ibid., fig. 11).

1 Stick Polished miniature florero. Approx. ht. $5 \mathrm{~cm}$ (ibid., fig. 12).

6 Shells, perforated (ibid., fig.2).

1 Strombus pendant, "Huaxtec style" (ibid., p 43, fig.2). 


\section{BURIALS AND OFFERINGS FROM LA VENTILLA A COMPOUND}

\section{Early Tlamimilolpa La Ventilla A "Ball Court Marker" Burial}

\section{Adult}

Provenience: Site 5:S1W2, Structure (System) I, T-shaped Altar/Platform with hole in center, burial at foot of stairway (Aveleyra Arroyo de Anda 1963: 17-18;1964: 26).

1 Polished black Tlaloc jar.

$4 \quad$ Fine Matte miniature floreros.

$1 \quad$ Painted red recurved bowl, small.

1 Polished brown recurved bowl, small.

Late Tlamimilolpa La Ventilla A, Burial 1

Age, sex unknown.

Provenience: Site 5:S1W2, Structure (System) I, Patio 2 (Bennyhoff 1964-1966).

2 Painted recurved specular red bowls with brown interiors. $\mathrm{Ht} .4 .5 \mathrm{~cm}$, diam. at rim $10.5 \mathrm{~cm}$, at base $7.5 \mathrm{~cm}$ MNA 9-3188.

1 Painted recurved specular red bowl, brown interior. $\mathrm{Ht} .5 \mathrm{~cm}$, diam. $14 \mathrm{~cm}$ at rim, at base $9.5 \mathrm{~cm}$

1 Polished brown plate. Diam. at rim $15 \mathrm{~cm}$ MNA 9-3188.

$1 \quad$ Fine Matte miniature cover-plate.

$1 \quad$ Painted small specular red bowl.

Late Tlamimilolpa La Ventilla A, Burial 2

Age, sex unknown.

Provenience: Site 5:S1W2, Structure I, Altar.

1 Painted specular red recurved bowl with everted rim, poorly fired. $\mathrm{Ht} .5 .5 \mathrm{~cm}$, diam. at rim $18 \mathrm{~cm}$, at base $13.5 \mathrm{~cm}$ MNA 9-3183.

1 Painted specular red recurved bowl, brown interior. $\mathrm{Ht} .6 \mathrm{~cm}$, diam. at rim $18 \mathrm{~cm}$, at base $12.5 \mathrm{~cm}$ MNA 9-3187.

1 Low Polished plate. Ht. $2 \mathrm{~cm}$, diam. at rim $10 \mathrm{~cm}$ MNA 9-3151. 


\section{Late Tlamimilolpa La Ventilla A, Burial 3}

Age, sex unknown.

Provenience: Site 5:S1W2, Structure I, Patio 2 (Bennyhoff 1964-1966).

5 Dense ware miniature bowls.

3 everted rim bowls, low polish. Ht. $3 \mathrm{~cm}$, diam. $7 \mathrm{~cm}$

2 incurved bowls, low polish. Ht. $3.5 \mathrm{~cm}$, diam. $7 \mathrm{~cm}$

$1 \quad$ Dense ware everted rim bowl. Ht. $4.5 \mathrm{~cm}$, diam. at rim $9.5 \mathrm{~cm}$ MNA 9-3090.

1 Painted Dense ware red on orange incurved bowl. Ht. $8 \mathrm{~cm}$, diam. at rim $12 \mathrm{~cm}$

1 Dense ware painted red border on orange incurved bowl. $\mathrm{Ht} .6 .5 \mathrm{~cm}$, diam. at rim $15.5 \mathrm{~cm}$ MNA 9-3061.

1 Polished corrugated shouldered bowl. Ht. $6 \mathrm{~cm}$, diam. at rim $12.5 \mathrm{~cm}$

2 Dense ware bi-pinched rim bowls with red borders on interior. Length $11 \mathrm{~cm}, \mathrm{Ht} .5 \mathrm{~cm}$, widths 9 and $9.5 \mathrm{~cm}$

5 Polished incurved miniatures in graduated sizes. Largest, ht. $4 \mathrm{~cm}$, diam. at rim $10 \mathrm{~cm}$; smallest, ht. $3.5 \mathrm{~cm}$, diam. at rim $5.5 \mathrm{~cm}$ MNA 9-3125, 3126, 3087, 3015, 3127.

2 Polished incurved bowls. Ht. $9 \mathrm{~cm}$, diam. at rim $15 \mathrm{~cm}$ MNA 9-3189.

4 Polished brown small everted rim bowls. Ht. $6.5 \mathrm{~cm}$, diam. at rim $11 \mathrm{~cm}$ MNA 9-3154.

1 Polished outcurving bowl with nubbin supports. Ht. $7 \mathrm{~cm}$, diam. at rim $22 \mathrm{~cm}$ MNA 9-3185.

2 Polished flaring bowls with slight.ly rounded bottoms: (1) ht. $4.5 \mathrm{~cm}$, diam. $12.5 \mathrm{~cm}$ (2) ht. $3.7 \mathrm{~cm}$, diam. $10.5 \mathrm{~cm}$

1 Polished outcurving bowl with pointed nubbins. Medium-sized. MNA 9-3106.

2 Low Polish outcurving bowls with everted rims and nubbin supports. (1) ht. $4.3 \mathrm{~cm}$, diam. at rim $10.5 \mathrm{~cm}$, (2) ht. $4.5 \mathrm{~cm}$, diam. $7.7 \mathrm{~cm}$ MNA 9-3124, 9-3190.

$1 \quad$ Low Polished simple bowl. Ht. $3.7 \mathrm{~cm}$, diam. $9.8 \mathrm{~cm}$

2 Fine Matte miniature flared bowls with small nubbins. MNA 9-3193.

1 Fine Matte miniature plate. MNA 9-3193.

1 Fine Matte miniature incurved bowl. MNA 9-3192. 
Late Tlamimilolpa La Ventilla A Burial 4

Age, sex unknown.

Provenience: Site 5:S1W2, Structure I, Patio 2, Room 10.

1 Polished brown monochrome incised vase with cut disk adornos and conical nubbins. Ht. $7.5 \mathrm{~cm}$, diam. at rim $9 \mathrm{~cm}$ MNA 9-4323.

Late Tlamimilolpa La Ventilla A Offering 1

Provenience: Site 5:S1W2, Structure II, Patio 2.

1 Polished outcurving bowl with nubbin supports. Diam. at rim $21.5 \mathrm{~cm}$, ht. $10 \mathrm{~cm}$, at base $13 \mathrm{~cm}$ MNA 9-3194.

Early Xolalpan La Ventilla A Burials 1A, 1B

1 Adult, 1 child.

Provenience: Site 19:S1W2, Structure III, Room 5, Temple platform (Bennyhoff 1964-66).

$1 \quad$ Polished "Kaminaljuyu" style vase with low relief scroll design, fine diagonal fluting and monkey head adornos around flange. Ht. $18 \mathrm{~cm}$, diam. at rim $15 \mathrm{~cm}$, at base $14 \mathrm{~cm}$, support $5 \mathrm{~cm}$ Apron lid with bird handle. MNA 9-2560 (Plate X).

1 "El Tajin" White on Lustrous cylindrical vase with plano-relief decoration. On display, Introductory Room to Museum

2 Thin Orange ring base bowls with incised and punctate decoration, small size.

1 Thin Orange ring base bowl with incised and punctate decoration. $\mathrm{Ht} .5 \mathrm{~cm}$, diam. $12.8 \mathrm{~cm}$ MNA 9-3092.

1 Thin Orange corrugated bowl with ring base.

1 Copa ware vase with molded supports. Ht. $9 \mathrm{~cm}$, diam. $12 \mathrm{~cm}$ MNA 9-3144.

1 Copa ware vase with basal torus and molded supports. $\mathrm{Ht} .10 \mathrm{~cm}$, diam. at rim $11.5 \mathrm{~cm}$, at base $10.5 \mathrm{~cm}$ MNA 9-3146.

$6 \quad$ Fine Matte miniature jars.

$8 \quad$ Low Polished flaring wall, everted rim bowls. 
Early Xolalpan La Ventilla A Burial 1

1 Adult.

Provenience: Site 19:S1W2, Structure III, Room 6

1 Gulf Coast Polished black recurved bowl with fluted walls and single panel of pseudo plano-relief. Ht. $10.5 \mathrm{~cm}$, diam. $14.5 \mathrm{~cm}$

1 Copa-like ware cylindrical vase without supports. Ht. $5.8 \mathrm{~cm}$, diam. at rim $8 \mathrm{~cm}$, at base $7.1 \mathrm{~cm}$ MNA 9-3122.

2 Thin Orange ring base bowls. $\mathrm{Ht} .6 .5 \mathrm{~cm}$, diam. at rim $28 \mathrm{~cm}$, at base $8 \mathrm{~cm}$ MNA 9-3048.

1 Thin Orange bowl with ring base, small-sized.

1 Thin Orange ring base bowl with incising and fine punctate.

1 Thin Orange channelled recurved bowl with ring base. $\mathrm{Ht} .5 \mathrm{~cm}$, diam. at rim $12 \mathrm{~cm}$, at base $6 \mathrm{~cm}$ MNA 9-3096 (Late Tlamimilolpa phase style).

$1 \quad$ Fine Matte flaring bowl.

$1 \quad$ Fine Matte simple bowl.

Early Xolalpan La Ventilla A Burial 1

2 Adults.

Provenience: Site 19:S1W2, Structure III, Room 12 (Bennyhoff 1964-1966).

1 Thin Orange ring base bowl with incised and punctate decoration. Ht. $7.2 \mathrm{~cm}$, diam. at rim $18.7 \mathrm{~cm}$, at base $8 \mathrm{~cm}$ MNA 9-3044.

2 Thin Orange ring base bowls.

1 Polished and incised wide mouth jar with "pattern polish" decoration. $\mathrm{Ht} .15 .3 \mathrm{~cm}$, diam. at rim $13.6 \mathrm{~cm}$, at base $9.2 \mathrm{~cm}$ MNA 9-3195.

$1 \quad$ Polished brown wide mouth jar with nubbins.

1 Polished black incised cylindrical vase with hollow cylindrical supports scars.

2 Fine Matte miniatures with red paint (unfired).

1 Shell bead, perforated.

8 Stone green beads. 
1 Slate fragment with red paint.

$2 \quad$ Shell plaques.

15 Clay cylinder beads.

Early Xolalpan La Ventilla A Burial 2

Age, sex unknown.

Provenience: Site 19:S1W2, Structure III, Room 5 (Bennyhoff 1964-1966).

1 Thin Orange ring base bowl with incised round punctate decoration. Ht. $3.6 \mathrm{~cm}$, diam. at rim $9.6 \mathrm{~cm}$, at base $4 \mathrm{~cm}$ MNA 9-3059.

11 Painted specular red bowls.

1 Shell necklace (16 bivalve, 4 univalve, 2 yellow pectorals, 211 "caracolitos", 75 "caracoles").

1 Green stone plaque.

$4 \quad$ Green stone beads.

1 White stone bead.

1 Pyrite fragment.

Early Xolalpan La Ventilla A Burial 3

Age, sex unknown.

Provenience: Site 19:S1W2, Structure III, Room 5.

1 El Tajín "Terrazas Lustroso" bowl with negative decoration. Ht. $9.5 \mathrm{~cm}$, diam. at rim $16 \mathrm{~cm}$, at base $9 \mathrm{~cm}$ MNA 9-3103 (Plate XI).

1 Polished brown outcurving bowl with nubbin supports and matte rim $\mathrm{Ht} .6 .7 \mathrm{~cm}$, diam. at rim $22 \mathrm{~cm}$ MNA 9-3185.

Early Xolalpan La Ventilla A Burial 4

Age, sex unknown.

Provenience: Site 19:S1W2, Structure III, Room 5.

1 Copa-like vase without supports. Ht. $6.5 \mathrm{~cm}$, diam. at rim, $9.5 \mathrm{~cm}$ MNA 9-3145.

1 Copa ware vase with hollow cylindrical supports. $\mathrm{Ht}$. $10.5 \mathrm{~cm}$, diam. at rim $11.5 \mathrm{~cm}$ MNA 9-3143. 
Early Xolalpan La Ventilla A Burial 5

Age, sex unkown.

Provenience: Site 19:S1W2, Structure III, Room 5

1 Painted specular red on natural jar, large, with nubbin supports.

Early Xolalpan La Ventilla A Compound Offering 2

No human bones reported.

Provenience: Site 19:S1W2, Structure III, Room 5 (in wall).

1 Gulf Coast Fine Paste cylindrical vase with human figure and "Tajín scrolls" in pseudo plano-relief. MNA 9-2561.

BURIALS AND OFFERINGS FROM LA VENTILLA B APARTMENT COMPOUND, TEOTIHUACAN

(Site 1:S1W3, From Vidarte 1964)

\section{LA VENTILLA B BURIALS: EARLY TLAMIMILOLPA PHASE}

Early Tlamimilolpa La Ventilla B Burial 13 (fig. 6)

1 Adult Female.

Provenience: Patio 5 "gran huella" (fig. 6; Vidarte 1964).

1 Polished outcurving bowl, brown, with nubbin supports.

1 Low Polish rounded base, everted rim bowl.

1 Low Polish everted rim bowl (not located in museum).

Early Tlamimilolpa La Ventilla B Burial 16 (Plate IV)

1 Adult Female.

Provenience: Patio 5, "gran huella" (fig. 6).

1 Painted miniature red on natural incised vase. $\mathrm{Ht} .6 .5 \mathrm{~cm}$, diam. at rim $6.1 \mathrm{~cm}$, at base, $5.3 \mathrm{~cm}$ MNA 9-2708.

1 Polished black jar with short neck and nubbin supports. $\mathrm{Ht} .12 .5 \mathrm{~cm}$, diam. at rim $11 \mathrm{~cm}$, at base $6.7 \mathrm{~cm}$ MNA 9-3017. 
$1 \quad$ Matte censer bowl.

$1 \quad$ Matte outcurving bowl.

Early Tlamimilolpa La Ventilla B Burial 21

1 Adult Male.

Provenience: Patio 5, "gran huella" (fig. 6, Plate III).

1 Polished black cylindrical vase with basal flange and "coffee bean" appliqué adornos, round tapered supports. MNA 9-2737.

1 Polished black outcurving bowl, incised with flush nubbin supports. $\mathrm{Ht} .3 .7 \mathrm{~cm}$, diam. at rim $12 \mathrm{~cm}$, at base $8 \mathrm{~cm}$ MNA 9-4332 4/9.

$1 \quad$ Polished outcurving bowl with incised "cloud motif". $\mathrm{Ht} .3 .5 \mathrm{~cm}$, diam. at rim $11 \mathrm{~cm}$, at base $7.5 \mathrm{~cm}$ MNA 9-4331 3/10.

$1 \quad$ Polished black florero.

$1 \quad$ Polished small jar.

1 Polished small incurving bowl.

2 Obsidian earspools.

1 jadeite nose ornament, butterfly shaped.

3 pyrite disks.

3 rings of shell.

$5 \quad$ unworked shells.

6 jadeite beads.

Early Tlamimilolpa La Ventilla B Burial 60

1 Young Female.

Provenience: Altar Room 3 (fig. 6).

Early Tlamimilolpa La Ventilla B Burial 61

1 Child.

Provenience: Altar Room 3 (fig. 6). 


\section{Early Tlamimilolpa La Ventilla B Burial 62}

2 children ages 4 and 6 .

Provenience: Altar Room 3 (fig. 6).

1 Polished outcurving bowl with flush nubbins incised. $\mathrm{Ht} .4 .3 \mathrm{~cm}$, diam. at rim $12.8 \mathrm{~cm}$, at base $8 \mathrm{~cm}$ MNA 9-4332.

1 Low Polished black outcurving bowl with small nubbin supports. Ht. $3.6 \mathrm{~cm}$, diam. at rim $10.3 \mathrm{~cm}$, at base $7 \mathrm{~cm}$ MNA 9-4332 7/9.

Early Tlamimilolpa La Ventilla B Burial 73 (Plate V)

2 Adult females.

Provenience: Adobe Room 3 south (fig. 6).

1 Polished short neck, medium sized jar.

$1 \quad$ Polished shot neck small jar.

1 Low Polish neckless jar, miniature.

1 Polished black florero.

1 Matte and Polished tecomate, large, covered with "thumbnail" gouge incising.

2 Polished small upright. bowls.

2 figures of diatomaceous earth.

1 ball of diatomaceous earth.

Early Tlamimilolpa La Ventilla B Burial 74

1 Adult Female.

Provenience: Adobe Room 3 south (fig. 6).

1 Polished globular jar.

1 Polished black-brown florero.

2 Polished black-brown plates.

2 Polished upright everted rim bowls.

7 Matte miniature paint pots with pigments (white, green, red). 
$5 \quad$ Diatomaceous earth figures.

Slate pieces with red markings.

Mica flakes.

Early Tlamimilolpa La Ventilla B Burial 76

1 Adult Female.

Provenience: Adobe Room 3 south (fig. 6).

1 Polished large vase with everted rim and nubbin supports.

$1 \quad$ Polished black florero.

2 Polishd small outcurving bowls with nubbin supports.

$5 \quad$ Matte miniature jars.

9 Figures of diatomaceous earth.

Miscellaneous shells.

Slate with red decoration (many fragments).

Early Tlamimilolpa La Ventilla B Burial 77

1 Adult Male.

Provenience: Adobe Room 3 (fig. 6).

1 Polished outcurving bowl, large.

1 Painted red-brown 3-handled jar.

1 Painted red rim incurved bowl, small.

1 Shell earspool.

1 Green obsidian blade.

Early Tlamimilolpa La Ventilla B Burial 87

1 Adult male.

Provenience: Patio 1E, Room 1 (fig. 6).

1 Thin Orange patojo (shoe pot) with nubbins, Ht. $12 \mathrm{~cm}$, length $19 \mathrm{~cm}$ MNA 9-2671.

1 Matte miniature bowl. MNA 9-2677. 
2 Polished black floreros, miniatures.

$4 \quad$ fragments of worked shell.

$1 \quad$ fragment shell figurine (?)

$1 \quad$ Matte miniature duck vessel. MNA 9-2677.

$1 \quad$ Matte miniature spouted plate MNA 9-2678.

$1 \quad$ Matte "tied" object MNA 9-2685.

3 Polished brown everted rim bowls.

Early Tlamimilolpa La Ventilla B Burial 88

1 Aged Male.

Provenience: Patio 1E, Room 1 (fig. 6).

1 Painted red on natural jar. Ht. $12.1 \mathrm{~cm}$, diam. at rim $11.6 \mathrm{~cm}$, at base $5 \mathrm{~cm}$ MNA 9-2655.

1 Polished outcurving bowl with "cloud motif" incising. $\mathrm{Ht} .6 .8 \mathrm{~cm}$, diam. at rim $21.5 \mathrm{~cm}$, at base $15.5 \mathrm{~cm}$ MNA 9-2694.

3 Low Polish small bowls.

$5 \quad$ Matte miniature plates.

2 shells.

Fragments of slate.

1 obsidian biface.

Early Tlamimilolpa La Ventilla B Burial 96

1 Infant.

Provenience: Patio 1E, Room 1 (fig. 6).

1 Polished outcurving bowl with pedestal base and negative-painted design. $\mathrm{Ht} .6 .5 \mathrm{~cm}$, rim diam. $13 \mathrm{~cm}$, at base $8 \mathrm{~cm}$ MNA 9-2724.

5 Matte miniature everted rim bowls.

$2 \quad$ Matte miniature upright. bowls.

$1 \quad$ Matte miniature wide mouth jar.

$1 \quad$ Matte shallow bowl with everted rim 
$1 \quad$ Matte miniature cover-plate.

1 mica disk.

1 obsidian blade.

Misc. ceramic objects, small unidentifiable.

Early Tlamimilolpa La Ventilla B Burial 100 (Plate VII)

1 Adult Female.

Provenience: Patio 1 South, Room 6A (fig. 6).

1 Polished high neck jar with excellent finish. Ht. $9.2 \mathrm{~cm}$, diam. at rim $8.5 \mathrm{~cm}$, maximum width $9 \mathrm{~cm}$ MNA 9-4512.

1 Painted red on natural and incised cylindrical vase with everted rim, MNA 9-2705.

2 Polished miniature amphoras. MNA 9-2685.

1 Polished groove incised black hemishperical bowl.

$1 \quad$ Matte tan jar, small.

$7 \quad$ Matte miniature plates.

1 Matte miniature cover-plate.

1 Stone mano and metate.

1 Obsidian blade.

1 Polished outcurving bowl.

Early Tlamimilolpa La Ventilla B Burial 110

1 Adult Male.

Provenience: Patio 1S, Room 6-A (Fig. 6, Plate VIII).

1 Alabaster Vase with 4 round truncated supports, Ht. approx. $7 \mathrm{~cm}$, diam. $10 \mathrm{~cm}$

1 Polished patojo (shoe vessel) with red border nubbin supports. $\mathrm{Ht} .14 \mathrm{~cm}$, diam. $9 \mathrm{~cm}$, length $14.5 \mathrm{~cm}$ MNA 9-2686.

6 Polished black low walled plates. MNA 9-2655.

1 Polished florero. Ht. $10 \mathrm{~cm}$, diam. at rim, $6.5 \mathrm{~cm}$ MNA 9-2649.

1 Polished florero. Ht. $16 \mathrm{~cm}$, diam. at rim, $11 \mathrm{~cm}$ MNA 9-2654. 
1 Polished recurved bowl. Ht. $5 \mathrm{~cm}$, diam. at rim $10 \mathrm{~cm}$ MNA 9-2652.

1 Polished recurved bowl. Ht. $4 \mathrm{~cm}$, diam. at rim $8 \mathrm{~cm}$

$4 \quad$ Matte ollitas, miniatures.

$7 \quad$ Bone needles.

2 Obsidian blades.

Misc. fragment of slate with red painted motifs.

$1 \quad$ Pyrite disk with pecked cross design.

Early Tlamimilolpa La Ventilla B Salvage Burial 111

1 Adult Male; 2 isolated skulls.

Provenience: Patio 1S, Room 6 (fig. 6, Plate VI).

8 Thin Orange ring base bowls (unused) in graduated sizes: $\mathrm{Ht} . \mathrm{s.} 3.8 \mathrm{~cm}, 4.2 \mathrm{~cm}(2), 4.3 \mathrm{~cm}$, $4.4 \mathrm{~cm}, 4.7 \mathrm{~cm}$ (3). Diam. at rim $6 \mathrm{~cm}, 6.2 \mathrm{~cm}(2), 6.5 \mathrm{~cm}(3), 7 \mathrm{~cm}$ (2). MNA 9-4336 13/13.

1 Painted red on natural incised vase with everted rim, nubbin supports $10 \mathrm{~cm}$, diam. at rim $12.5 \mathrm{~cm}$

1 Polished outcurving bowl with flush nubbins. $\mathrm{Ht} .4 \mathrm{~cm}$, diam. at rim $11.2 \mathrm{~cm}$ MNA 9-4332 6/9.

1 Polished recurved bowl. Ht. $9 \mathrm{~cm}$, diam. at rim $19 \mathrm{~cm}$

$1 \quad$ Burnished reddish-brown pointed base olla.

$1 \quad$ Polished black jar with nubbins.

$2 \quad$ Matte plates, black.

2 Matte incurving bowls.

1 Figurine, diatomaceous earth.

$2 \quad$ Manos and metates.

1 Mica disk.

Fragments of slate with red motifs. 
Early Tlamimilolpa La Ventilla B, Salvage Burial 9

1 Adult Female.

Provenience: Patio 1W Room 9 (fig. 6)

1 Polished widemouth jar.

1 Matte 3-pronged burner.

1 Conch shell; snails.

Early Tlamimilolpa La Ventilla B, Salvage Burial 18

1 Individual, undetermined age, sex.

Provenience: Patio 5A, Lower level (fig. 6).

1 Polished simple bowl. Ht. $4.5 \mathrm{~cm}$, diam. at rim $16.5 \mathrm{~cm}$ MNA 9-4429.

1 Polished cazuela, fluted body. Ht. $8.8 \mathrm{~cm}$, diam. at rim $17.5 \mathrm{~cm}$ MNA 9-4511.

1 Polished vase, miniature Ht. $6.5 \mathrm{~cm}$, rim at diam.eter $8 \mathrm{~cm}$

1 Polished black low walled plate, diam. $6 \mathrm{~cm}$

1 Polished black low walled plate, small.

4 Polished black floreros, one with incised body and zone polished rim

$1 \quad$ Polished jar with flaring rim

2 Polished jars.

1 Stucco-painted (green and red) cylindrical vase with incised "V" design.

1 Matte miniature ollita.

$4 \quad$ Polished recurved bowls.

$2 \quad$ Matte miniature plates.

$1 \quad$ Polished outcurving bowl.

2 Clay mortars. Ht. $3 \mathrm{~cm}$

Misc. miniature clay cylinders.

Obsidian blade.

Diatomaceous earth figurines.

1 bone awl. 
Early Tlamimilolpa La Ventilla B Salvage Burial 20

1 Adult Female.

Provenience: Patio 5A (fig. 6).

1 Polished black gadrooned jar (rim broken off) (fig. 75). $\mathrm{Ht} .12 \mathrm{~cm}$, diam. at rim $12 \mathrm{~cm}$

1 Polished black incised outcurving bowl. Ht. $3 \mathrm{~cm}$, diam. at $\operatorname{rim} 9 \mathrm{~cm}$

1 Polished black outcurving bowl.

1 Polished brown miniature flaring bowl, $\mathrm{Ht} .2 \mathrm{~cm}$, diam. at rim $5.5 \mathrm{~cm}$

$1 \quad$ Matte miniature plate.

1 Obsidian blade.

1 Fragment figurine.

Early Tlamimilolpa La Ventilla B Burial 31

1 Adult Female.

Provenience: Patio 5A (fig. 6).

1 Polished incised ("interlace motif") long neck jar, everted rim Ht. $14.5 \mathrm{~cm}$, diam. at rim $11.5 \mathrm{~cm}$ MNA 9-3048.

1 Pointed white on red vase with flush nubbins. Ht. $12 \mathrm{~cm}$, diam. at rim $14 \mathrm{~cm}$ MNA 9-3035.

1 Polished globular jar. Ht. $9.2 \mathrm{~cm}$, diam. at rim, $9.5 \mathrm{~cm}$ MNA 9-3035.

1 Polished brown recurved bowl.

1 Polished wide mouth jar.

4 Diatomaceous earth figurines.

1 Stamp with intricate design.

2 Obsidian blades.

4 Fragments slate, with red lines.

1 Matte miniature cradle.

1 Burnished olla sherds. 


\section{LA VENTILLA B COMPOUND: LATE TLAMIMILOLPA BURIALS}

Late Tlamimilolpa La Ventilla B, Burial 3

1 Adult Female.

Provenience: Patio 5, "gran huella" (large pit) (fig. 6).

2 Painted red (specular) upright. bowls. Ht. $4.8 \mathrm{~cm}$, diam. at rim $12.8 \mathrm{~cm}$, diam. at base 9 and $10 \mathrm{~cm}$ MNA 9/4356 1/6.

1 Polished cylindrical vase with nubbin supports. $\mathrm{Ht} .8 \mathrm{~cm}$, diam. at rim $11 \mathrm{~cm}$, at base $10.2 \mathrm{~cm}$ MNA 9/4325 4/5.

1 Thin Orange ring base bowl, broken, medium-sized.

$1 \quad$ Polished outcurving bowl.

2 Matte miniature ollitas (1 with 3 handles).

$1 \quad$ Matte wide mouth jar with 3 handles.

$2 \quad$ Matte miniature floreros.

1 Low Polish wide mouth jar.

2 Low Polish flaring bowls.

$2 \quad$ Matte miniature plates.

$1 \quad$ Low Polish incurving bowl.

25+ Matte "finger rolls".

6 Obsidian blades.

1 Conch shell, perforated.

Late Tlamimilolpa La Ventilla B, Burial 10

1 Male Adult.

Provenience: Patio 5, East of "gran huella" (large pit) (fig. 6).

1 Polished brown-black spouted copa. $\mathrm{Ht} .12 .9 \mathrm{~cm}$, diam. at rim $8.2 \mathrm{~cm}$ at base $4.8 \mathrm{~cm}$ MNA $9 / 2486$.

1 Polished black spouted bowl with flat base. $\mathrm{Ht} .5 .3 \mathrm{~cm}$, diam. at rim $8.2 \mathrm{~cm}$, diam. at base $4.8 \mathrm{~cm}$ MNA $9 / 4475$.

1 Polished lustrous black, everted rim recurved bowl. $\mathrm{Ht} .5 \mathrm{~cm}$, diam. at rim $11 \mathrm{~cm}$ MNA 9/4356 5/6. 
1 Polished dark brown patojo (shoe vessel) with nubbin supports. $\mathrm{Ht} .10 .8 \mathrm{~cm}$, diam. at rim $7.4 \mathrm{~cm}$, diam. at base $8 \mathrm{~cm}$, maximum length $12 \mathrm{~cm}$ MNA 9/3054.

3 Painted red on natural incised miniature vases with nubbin supports and everted rims. Ht. $4.3 \mathrm{~cm}$, diam. at rim $5.4 \mathrm{~cm}$, at base $4.2 \mathrm{~cm}$ MNA 9-3058.

$2 \quad$ Painted red on natural incised vases with everted rims. Ht. $6.5 \mathrm{~cm}$, diam. at rim 8 and $8.5 \mathrm{~cm}$, at base $6.5 \mathrm{~cm}$ MNA 9/3076, 9/3054.

$4 \quad$ Polished outcurving bowls, medium sized.

1 Polished outcurving bowl with incising, "cloud motif" and nubbin supports. $\mathrm{Ht} .8 .5 \mathrm{~cm}$, diam. at rim $25.4 \mathrm{~cm}$, at base $17.5 \mathrm{~cm}$ MNA 9/3047.

1 Polished incurving bowl.

$1 \quad$ Polished black florero.

1 Polished wide mouth jar.

$4 \quad$ Matte miniature ollitas.

$1 \quad$ Painted red recurved bowl.

$1 \quad$ Effigy vessel, possible monkey.

6 Low Polish outcurving bowls.

1 Spoon with recurved handle.

$1 \quad$ Fluted bun-shaped "malacate".

3 Diatomaceous earth figurines.

1 Handmade figurine, pastillaje.

$2 \quad$ Unfired vessels.

Late Tlamimilolpa La Ventilla B, Burial 12

1 Infant, age 4 to 5 .

Provenience: Patio 1 South, Room 4 (fig. 6).

1 Painted bichrome specular red on natural jar with two small handles. Diam. at rim, $7 \mathrm{~cm}$, ht. $17 \mathrm{~cm}$ MNA 9-2880.

1 Polished incurving bowl. 
Late Tlamimilolpa La Ventilla B, Burial 37-38

1 Adult Male.

Provenience: Patio 1W, Room 15 (fig. 6).

1 Polished brown sieve-top container. Ht. $5.2 \mathrm{~cm}$, diam. at top $108 \mathrm{~cm}$, at base $103 \mathrm{~cm}$

$1 \quad$ Low Polished wide mouth jar.

$5 \quad$ Polished wide mouth jars.

1 Polished wide mouth jar, zone polished. $\mathrm{Ht} .15 .5 \mathrm{~cm}$, diam. at rim $14 \mathrm{~cm}$, at base $8.5 \mathrm{~cm}$

1 Thin Orange ring base bowl. Ht. $4 \mathrm{~cm}$, diam. at rim $11.5 \mathrm{~cm}$, diam. at base $4.5 \mathrm{~cm}$

1 Thin Orange ring base bowl w/incising. $\mathrm{Ht} .4 .5 \mathrm{~cm}$, diam. at rim $8.5 \mathrm{~cm}$, at base $2.5 \mathrm{~cm}$

1 Polished outcurving bowl with flush nubbin supports.

Diatomaceous earth figurines.

$1 \quad$ Handmade figurine.

$1 \quad$ Slate flake, painted red.

1 Cotton cloth.

Late Tlamimilolpa La Ventilla B, Burial 41

1 Adult male.

Provenience: "Adobe room" (fig. 6).

$1 \quad$ Polished wide mouth jar. Ht. $12.5 \mathrm{~cm}$, diam. at rim $13 \mathrm{~cm}$, at base $7.5 \mathrm{~cm}$ MNA 9-4334 1/2.

1 Polished wide mouth jar with everted rim and "vestigial" nubbins. Ht. $12.7 \mathrm{~cm}$, body, maximum diam. $14.1 \mathrm{~cm}$ MNA 9/4334 2/2.

1 Polished wide mouth jar, large.

2 Polished wide mouth jars, small.

1 Polished dark brown recurved bowl with everted rim

$1 \quad$ Matte miniature bowl.

$2 \quad$ Matte miniature plates. 
Late Tlamimilolpa La Ventilla B, Burial 42

1 Adult Male.

Provenience: "Adobe Room" (fig. 6).

1 Thin Orange ring base bowl. Ht. $3.3 \mathrm{~cm}$, diam. at rim $11.3 \mathrm{~cm}$, at base $5 \mathrm{~cm}$ MNA 9-4362.

1 Polished outcurving bowl with nubbin supports. $\mathrm{Ht} .4 \mathrm{~cm}$, diam. at rim, $10.5 \mathrm{~cm}$, at base $8 \mathrm{~cm}$ MNA 9/4332 9/9.

1 Polished outcurving bowl with nubbins. Ht. $3.8 \mathrm{~cm}$, diam. at rim $10.8 \mathrm{~cm}$, at base $7 \mathrm{~cm}$ MNA 9/4332 3/9.

1 Low Polished flaring bowl. Ht. $3 \mathrm{~cm}$, diam. at rim $10.3 \mathrm{~cm}$, at base $6 \mathrm{~cm}$ MNA 9/4362 5/6.

1 Matte miniature bowl. Ht. $3.5 \mathrm{~cm}$, diam. at rim $10 \mathrm{~cm}$ MNA 9/4356 2/6.

1 Polished flaring bowl. Ht. $3.3 \mathrm{~cm}$, diam. at rim $10.3 \mathrm{~cm}$, at base $6 \mathrm{~cm}$ MNA 9-4331 6/10. Misc. Matte miniatures, jars, bowls. MNA 9/4838, 9/4846 3/3.

Late Tlamimilolpa La Ventilla B Burial 66

1 Adult Male.

Provenience: Patio 1E, Room 1 (fig. 6, Plate IX, fig. 9).

1 Matte miniature amphora.

8 Matte miniature ollitas, 3 with handles.

8 Matte miniature plates, bowls.

$1 \quad$ Matte miniature florero.

1 Polished black miniature florero.

1 Polished miniature vase.

1 Polished miniature globular jar with handled lid.

1 Matte miniature 3-prong burner.

Misc. Matte dishes. MNA 9/4847.

$1 \quad$ Matte spouted dish.

1 Matte obtuse-angled dish.

$1 \quad$ Matte handled cover-plate. 
1 Polished upright. bowl. Ht. $6.4 \mathrm{~cm}$, diam. at rim $18 \mathrm{~cm}$ at base $13 \mathrm{~cm}$ MNA 9-2913.

1 Polished outcurving bowl with inset nubbins. Ht. $6.5 \mathrm{~cm}$, diam. at rim $20.8 \mathrm{~cm}$, at base $13.5 \mathrm{~cm}$

1 Polished outcurving bowl.

$1 \quad$ Painted red on natural incised and modeled bird effigy vessel with shell ornaments. Ht. $25 \mathrm{~cm}$ Length approx. $40 \mathrm{~cm}$ (fig. 9, Plate IX).

1 Polished black vase with hollow globular supports.

1 Painted red on natural incised, everted rim miniature vase.

$1 \quad$ String of shell beads (approx. 50).

2 Pair earrings of red shell.

1 Stone palette.

1 Stone mano, knob-shaped.

2 Stone beads, bun-shaped.

$4 \quad$ Obsidian blades.

Late Tlamimilolpa La Ventilla B Burial 71

1 Juvenile.

Provenience: Patio 1E, Room 1 (fig. 6).

1 Painted red, recurved bowl. Ht. $3.1 \mathrm{~cm}$, diam. at rim $9.8 \mathrm{~cm}$, at base $7 \mathrm{~cm}$ MNA 9/4356 6/6.

1 Polished brown wide mouth jar with nubbins.

1 Polished outcurving bowl light. brown.

$1 \quad$ Painted red on natural miniature vase with nubbins.

2 Matte miniature plates.

1 Mica disk. 
Late Tlamimilolpa La Ventilla B Burial 82

1 Adult Female.

Provenience: Adobe Room 2 (fig. 6).

1 Polished outcurving bowl. Ht. $4.3 \mathrm{~cm}$, diam. at rim $17.5 \mathrm{~cm}$ MNA 9/4344 4/11.

1 Polished outcurving bowl with "vestigial" nubbins. $\mathrm{Ht} .5 .5 \mathrm{~cm}$, diam. at rim $17.4 \mathrm{~cm}$, at base $12 \mathrm{~cm}$ MNA 9/4344 1/11.

2 Matte bowls: (1) Ht. $3.5 \mathrm{~cm}$, diam.eter at rim $14 \mathrm{~cm}$, (2) Ht. $3.5 \mathrm{~cm}$, diam. at rim $14 \mathrm{~cm}$ MNA 9-4353 5/5.

Matte miniature plate.

Late Tlamimilolpa La Ventilla B Burial 86A

Child (about 2 years old).

Provenience: Room with "white wall" (fig. 6).

2 Polished black outcurving bowls, large size.

2 Polished black miniature recurved bowls with everted rim

$1 \quad$ Matte miniature ollita with "split disk" adornos.

Late Tlamimilolpa La Ventilla B Burial 95

1 Child, age 4-5.

Provenience: Patio 1E, Room 1 (fig. 6).

2 Polished outcurving bowls, 1 incised with "cloud motif".

1 Polished wide mouth jar with nubbins.

$1 \quad$ Matte miniature plate.

Late Tlamimilolpa La Ventilla B Burial 114

1 Adult.

Provenience: unknown.

1 Polished outcurving bowl with nubbin supports. $\mathrm{Ht} .3 .5 \mathrm{~cm}$, diam. at rim $11 \mathrm{~cm}$, at base $7 \mathrm{~cm}$ MNA $9 / 43328 / 9$. 
Late Tlamimilolpa La Ventilla B Salvage Burial 1

1 Adult Female.

Provenience: Patio 1S, Room 6A (fig. 6).

1 Polished outcurving bowl, with inset nubbins. $\mathrm{Ht} .7 \mathrm{~cm}$, diam. at $\operatorname{rim} 20 \mathrm{~cm}$, at base $12.5 \mathrm{~cm}$ MNA 9-4344 7/11.

1 Polished outcurving bowl with flush nubbins. $\mathrm{Ht} .5 \mathrm{~cm}$, diam. at rim $16 \mathrm{~cm}$, at base $12 \mathrm{~cm}$ MNA 9-4344 7/11.

1 Polished outcurving bowl with flush nubbins. Ht. $5.6 \mathrm{~cm}$, diam. at rim $16.7 \mathrm{~cm}$, at base $11 \mathrm{~cm}$ MNA 9-4344 3/11.

1 Polished outcurving bowl. Ht. $4.6 \mathrm{~cm}$, diam. at rim $16 \mathrm{~cm}$, at base $11 \mathrm{~cm}$

1 Polished wide mouth jar.

1 Diatomaceous earth figurine.

$1 \quad$ Mica disk.

Late Tlamimilolpa La Ventilla B Salvage Burial 2

1 Adult, undetermined sex.

Provenience: Patio IW, Room 8 (fig. 6).

1 Polished wide mouth jar with nubbins.

1 Polished flaring bowl.

1 Polished upright bowl.

1 Polished flaring base with everted rim

$1 \quad$ Figurine with post-fire paint.

Late Tlamimilolpa La Ventilla B Salvage Burial 5

1 Male Adult.

Provenience: Patio 1W, between Rooms 6 and 15 (fig. 6).

1 Polished wide mouth jar. Ht. $9.8 \mathrm{~cm}$, diam. at rim $11.2 \mathrm{~cm}$, at base $7 \mathrm{~cm}$ MNA 9-4520.

1 Polished wide mouth jar with zone polished design. $\mathrm{Ht} .9 .2 \mathrm{~cm}$, diam. at rim $9.3 \mathrm{~cm}$, at base $6.5 \mathrm{~cm}$ MNA 9-3028.

1 Polished wide mouth jar, small. MNA 9-2666.

1 Gulf Coast Marfil Polished miniature vase, filled with white material. 
$1 \quad$ Low Polish bowl.

9 Obsidian blades.

Late Tlamimilolpa La Ventilla B Salvage Burial 11

1 Individual.

Provenience: West Adobe, Room 2 (fig. 6).

1 Thin Orange ring base bowl. Ht. $6.5 \mathrm{~cm}$, diam. at rim $21.4 \mathrm{~cm}$, at base $8 \mathrm{~cm}$ MNA 9-4336 13/13.

1 Painted red on natural outflaring bowl with everted rim and nubbin supports. $\mathrm{Ht} .4 .2 \mathrm{~cm}$, diam. at rim $13.7 \mathrm{~cm}$, at base $8.2 \mathrm{~cm}$ MNA 9-2718.

$1 \quad$ Polished wide mouth jar.

Late Tlamimilolpa La Ventilla B Salvage Burial 13

1 Individual, incinerated.

Provenience: Patio 10 North, Room 2 (fig. 6).

1 Polished black florero, fragments.

1 Candelero, incised decoration.

2 Low Polish plates.

1 Painted red on natural miniature vase with supports.

1 Polished black incised tecomate.

Late Tlamimilolpa La Ventilla B Salvage Burial 25

1 Adult Female.

Provenience: Patio 1W, Room 15 (fig. 6).

1 Thin Orange ring base bowl.

2 Balls diatomaceous earth. 


\section{EARLY XOLALPAN BURIALS: LA VENTILLA B COMPOUND}

Early Xolalpan La Ventilla B Burial 2

1 Adult Female.

Provenience: Room outside south wall (fig. 6).

1 Copa ware vase.

3 obsidian blades.

Early Xolalpan La Ventilla B Burial 11

1 Adult Female.

Provenience: Patio 5, Room to South (fig. 6).

1 Thin Orange vase with globular supports (Matte plates with infant burial in layers above; Vidarte 1964: 82).

Early Xolalpan La Ventilla B Burial 31

1 Adult Male.

Provenience: Patio 7 South, Room 3 (fig. 6).

1 Copa vase with basal flange and diagonally incised design.

1 Matte miniature ollita.

$1 \quad$ Matte miniature florero.

1 Matte miniature 3-prong burner.

1 Matte ollita with 3 loop handles.

Early Xolalpan La Ventilla B Burial 32 (associated with Burial 31)

1 Adult Male.

Provenience: Patio 7 South, Room 3 (fig. 6).

1 Matte 3-prong burner.

1 Portrait figurine with yellow face paint. 
Early Xolalpan La Ventilla B Burial 49

1 Adult Male, 1 Adult Female.

Provenience: Patio 1W, Room A1 W (fig. 6).

1 Cylindrical vase, bicurvate with openwork hollow cylindrical supports. Matte surface and traces of red stucco. Ht. $14.5 \mathrm{~cm}$, diam. at rim $14.2 \mathrm{~cm}$ MNA 9-2966.

1 Copa vase with basal torus. Resist and red on natural painted decoration. $\mathrm{Ht} .11 \mathrm{~cm}$, diam. $10 \mathrm{~cm}$ MNA 9-2833.

2 Miniature red dishes with round piece of clay in interior, perhaps an offering. $\mathrm{Ht} .2 \mathrm{~cm}$, diam. $8 \mathrm{~cm}$

1 Polished black jar, gadrooned, short neck. Ht. $7.8 \mathrm{~cm}$, diam. at rim $8.8 \mathrm{~cm}$, at base $5.6 \mathrm{~cm}$ MNA 9-4414.

Early Xolalpan La Ventilla B Burial 93 A, B

1 Adult Male, 1 Young Adult Female.

Provenience: Patio 1E, Room 1 (fig. 6).

1 Painted red upright. bowl. Ht. $7 \mathrm{~cm}$, diam. at rim $17 \mathrm{~cm}$, diam. at base $12 \mathrm{~cm}$

1 Thin Orange ring base bowl with incised punctate decoration.

1 Polished wide mouth jar.

$1 \quad$ Polished cylindrical vase.

3 Matte miniature bowls.

2 Matte miniature plates.

Early Xolalpan Burial 14

1 Adult Male.

Provenience: North of Patio 1W, Room 6 (fig. 6).

1 Thin Orange cylindrical vase with incision.

2 Thin Orange hemispherical bowls.

1 Matte plate. 


\section{Early Xolalpan La Ventilla B Offering 2A}

Provenience: Patio 1E, east of room 1 (fig. 6)

1 Matte miniature ollita with 3 handles, round base. $H t .5 .9 \mathrm{~cm}$, diam. at rim $4.1 \mathrm{~cm}$, at base $2.5 \mathrm{~cm}$ MNA 9-2690.

5+ Matte miniature ollitas with handles.

$1 \quad$ Matte upright rim small jar.

2 Matte miniature cover-plates with tab handles.

2 Matte miniature ollitas with nubbins.

$1 \quad$ Matte miniature amphora.

15 Matte miniature floreros.

$4 \quad$ Matte miniature flaring bowls.

40+ Matte miniature ollitas.

20+ Matte miniature plates.

24+ Matte miniature bowls.

$4 \quad$ Matte flaring bowls, small.

5+ $\quad$ Painted red miniature plates.

5+ $\quad$ Matte miniature tumblers.

3 Green obsidian blades.

Stone implements.

Mica.

Shell.

Slate fragments.

Chert. 


\section{LATE XOLALPAN BURIALS: LA VENTILLA B COMPOUND}

\section{Late Xolalpan La Ventilla B Burial 17}

1 Adult Female.

Provenience: Patio 1E, Room 2 (fig. 6).

1 Polished cylindrical vase with remnants of paint, molded head adornos around basal flange. Diam. at rim $13 \mathrm{~cm}$, ht. $14 \mathrm{~cm}$

1 Polished lid with simple knob and round pastillaje buttons on overhang.

3 Shells.

\section{Late Xolalpan La Ventilla B Burial 19}

Partial Cremation, Adult Male.

Provenience: Patio 10 (fig. 6).

1 Copa Ware vase with negative design around top and smooth groove incised curvilinear motif on lower half. Ht. $10 \mathrm{~cm}$, diam. at rim $13 \mathrm{~cm}$, diam. at base $11 \mathrm{~cm}$ Typical mold-made supports (extremely burnt). MNA 9-3009.

1 Copa ware vase, brownish-orange with diagonal incised motif and basal torus. $\mathrm{Ht} .13 \mathrm{~cm}$, diam. at rim $16 \mathrm{~cm}$, at base $14.5 \mathrm{~cm}$ MNA 9-4325 2/2.

1 Copa ware copa with negative design. MNA 9-2600.

$1 \quad$ Polished incised vase with hollow bud-like supports.

1 Thin Orange ring base bowl. Ht. $6.5 \mathrm{~cm}$, diam. at rim $20 \mathrm{~cm}$, ring base $8 \mathrm{~cm}$ MNA 9-4336 9/13 (restored).

1 Thin Orange ring base bowl (similar to above).

2 Matte miniature floreros.

2 Matte miniature cover-plates (tapa-platos) with tab legs.

$1 \quad$ Matte miniature jar.

$1 \quad$ Low Polish small plate.

1 Polished small bowl.

1 Burner prong.

1 Puppet figurine. 
1 Cone of diatomaceous earth.

1 Clay "bundle".

2 fragments mica.

Misc. Matte censer ornaments.

$1 \quad$ Censer bowl.

8 Jade beads.

2 Carbonized beads.

Late Xolalpan La Ventilla B Burial 35

1 Adult male.

Provenience: Patio 1 West, west of room 1 (fig. 6).

3 Low Polished outcurving bowls.

1 Painted specular red on natural bowl.

1 Low Polished and "stick trailed" flaring bowl.

3 Matte miniature ollitas.

1 Matte miniature jar with 3 handles.

$5 \quad$ Matte miniature plates.

1 Matte miniature cover-plate.

2 Matte miniature bowls.

1 Matte miniature 3-prong burner.

1 Matte miniature amphora.

$1 \quad$ Matte miniature florero.

1 Stone "flatiron" polisher. 
Late Xolalpan La Ventilla B Burial 36

1 Aged Male.

Provenience: Patio 1 West, between rooms 6 and 15 (fig. 6).

1 Polished outcurving bowl with pattern polish design in interior. $\mathrm{Ht.} 4 \mathrm{~cm}$, diam. at rim $15 \mathrm{~cm}$, at base $8.5 \mathrm{~cm}$ MNA 9-4362 1/6.

1 Matte plate with "finger ridged" exterior. $\mathrm{Ht} .2 .5 \mathrm{~cm}$, diam. at rim $14 \mathrm{~cm}$ MNA 9-4353 4/5.

$1 \quad$ Polished wide mouth jar with nubbin supports.

$1 \quad$ Polished cylindrical vase with round hollow supports.

1 Polished cylindrical vase (fragmentary).

1 Thin Orange bowl with incised and punctate decoration.

2 Plaster polishers.

Late Xolalpan La Ventilla B Burial 58-59

1 Adult Male, 1 Young adult male.

Provenience: Altar III Room (fig. 6).

1 Polished incised cylindrical vase with basal torus and large hollow round supports. Ht. $12.8 \mathrm{~cm}$, diam. at rim $16.4 \mathrm{~cm}$, at base $15.5 \mathrm{~cm}$ MNA 9-4323 5/5.

1 Polished outcurving bowl with pattern polish design. $\mathrm{Ht} .6 \mathrm{~cm}$, diam. at rim $21 \mathrm{~cm}$, at base $13 \mathrm{~cm}$ MNA 9-4332.

$1 \quad$ Polished bowl with everted rim and nubbin supports.

2 Matte miniature bowls.

Slate.

Late Xolalpan Burial 86 (B) La Ventilla B

1 Adult Female.

Provenience: Room "White wall" (fig. 6).

1 Thin Orange effigy (dog or coyote) with red paint. $\mathrm{Ht} .10 \mathrm{~cm}$, length $18 \mathrm{~cm}$, diam. at rim $6 \mathrm{~cm}$, at base $12 \mathrm{~cm}$ MNA 9-2492.

1 Polished squat vase with hollow round supports (large fragment).

3 Shells.

1 obsidian point. 
Late Xolalpan La Ventilla B Burial 119

2 Fetuses.

Provenience: unknown.

1 Fine Matte cover-plate (tapaplato). Diam. at rim $20 \mathrm{~cm}$ MNA 9-4358 8/8.

Late Xolalpan La Ventilla B Salvage Burial 4

1 Adult Female.

Provenience: Patio 1W, Room 15 (fig. 6).

1 Polished wide mouth jar with nubbin supports and pattern polished neck. Ht. $18.8 \mathrm{~cm}$, diam. at rim $16.1 \mathrm{~cm}$, at base $15 \mathrm{~cm}$ MNA 9-4510.

Late Xolalpan La Ventilla B Salvage Burial 22 (shared with 21)

1 Adult Male.

Provenience: Patio 1W, West of Room 1 (fig. 6).

1 Thin Orange ring base bowl. Ht. $4.5 \mathrm{~cm}$, diam. at rim $13.3 \mathrm{~cm}$, at base $3 \mathrm{~cm}$ MNA 9-2909.

1 Thin Orange ring base bowl with incised and punctate decoration. Ht. $3.3 \mathrm{~cm}$, diam. at rim $9.5 \mathrm{~cm}$, diam. at base $4 \mathrm{~cm}$ MNA 9-4336 2/13.

$1 \quad$ Matte miniature plate.

1 Obsidian blade.

$2 \quad$ Mica disks.

Late Xolalpan La Ventilla B, Salvage Burial 24

1 Adult Male.

Provenience: Patio 1, next to Room 6 (fig. 6).

1 Thin Orange ring base bowl, worn on interior. Ht. $7.4 \mathrm{~cm}$, diam. at rim $19.5 \mathrm{~cm}$, at base $7 \mathrm{~cm}$ MNA 9-4336 12/13.

1 Thin Orange ring base bowl. Ht. $4.5 \mathrm{~cm}$, diam. at rim $12 \mathrm{~cm}$

1 Thin Orange cylindrical vase with round supports. Incised star motif and simple round disks. Ht. $6 \mathrm{~cm}$, diam. at rim $9 \mathrm{~cm}$

1 Low Polish outcurving bowl with rounded base. Ht. $2.5 \mathrm{~cm}$, diam. at rim $14 \mathrm{~cm}$, at base $9 \mathrm{~cm}$ MNA 9-4362 4/6. 
Late Xolalpan La Ventilla B Offering 1

No bone reported.

Provenience: Patio 1 East, Room 1 East.

1 Copa ware vase, orange-brown with incised curvilinear motif and molded supports. Ht. $13 \mathrm{~cm}$, diam. at rim $14 \mathrm{~cm}$, at base $10.5 \mathrm{~cm}$ MNA 9-4325 1/2.

1 Thin Orange ring base bowl. Ht. $7 \mathrm{~cm}$, diam. at rim $22.7 \mathrm{~cm}$, at base $9.9 \mathrm{~cm}$ MNA 9-3042.

1 Low Polish flaring bowl. Ht. $3.7 \mathrm{~cm}$, diam. at rim $14.1 \mathrm{~cm}$, at base $9 \mathrm{~cm}$ MNA 9-4362 5/6.

1 Matte miniature 3 prong burner with cutout wall. $\mathrm{Ht} .4 \mathrm{~cm}$, diam. at rim $6 \mathrm{~cm}$, at base $2.5 \mathrm{~cm}$ MNA 9-2697.

$1 \quad$ Matte miniature 3 prong burner.

$1 \quad$ Matte miniature cover-plate.

1 Matte miniature amphora.

$1 \quad$ Matte miniature vase.

$1 \quad$ Matte censer ornament.

1 Matte miniature ollita.

Late Xolalpan La Ventilla B Offering 4

No bone reported.

Provenience: Patio 1E, Room 1 East.

1 Copa ware vase, reddish orange, with typical molded supports. $\mathrm{Ht} .13 \mathrm{~cm}$, diam. at rim $12.3 \mathrm{~cm}$, at base $11 \mathrm{~cm}$ MNA 9-2968.

$5 \quad$ Matte small plates.

1 Matte miniature ollita.

$1 \quad$ Low polish outcurving bowl.

Late Xolalpan La Ventilla B Offering 5

No bone reported.

Provenience: Patio 1E, Room 1 East.

3 Matte everted rim dishes.

$1 \quad$ Matte upright. bowl. 
$8 \quad$ Matte miniature plates.

$5 \quad$ Matte miniature ollita.

1 Matte miniature cazuelita.

$1 \quad$ Matte miniature 3 prong burner.

2 Matte miniature floreros.

1 Matte minature cover-plate.

$1 \quad$ Matte miniature duck vessel.

$2 \quad$ Matte miniature spouted bowl.

$1 \quad$ Painted red dish small.

\section{METEPEC BURIALS: LA VENTILLA B COMPOUND}

Metepec La Ventilla B Burial 6

1 Adult Female.

Provenience: Patio 1 west, Room 13 (fig. 6).

1 Copa ware vase, tan, with cylindrical, round bottom supports. $H$ t. $11.5 \mathrm{~cm}$, diam. at rim $11.8 \mathrm{~cm}$, at base $10.2 \mathrm{~cm}$ MNA 9-4323 $3 / 5$.

1 Low Polish plate, tan.

Metepec La Ventilla B Burial 7

1 Adult Male.

Provenience: Patio 1 West, Room 13.

1 Polished (poorly) outcurving bowl with pattern polish interior. $\mathrm{Ht} .3 \mathrm{~cm}$, diam. at rim $18 \mathrm{~cm}$, diam. at base $10 \mathrm{~cm}$

1 Polished vase with round hollow supports. Ht. $9.5 \mathrm{~cm}$, diam. at rim $10 \mathrm{~cm}$, at base $9 \mathrm{~cm}$ MNA 9-4323 3/5.

1 Slate plaque with red decoration. 


\section{Metepec La Ventilla B Burial 8}

\section{Adult Female.}

Provenience: Patio 1 west, Room 13 (fig. 6).

1 Polished outcurving bowl with pattern polish design on interior.

\section{Metepec La Ventilla B Burial 9}

1 Young individual.

Provenience: Patio 1S, Room 7 (fig. 6).

1 Polished cylindrical vase, cream colored, resist painted, incised, with molded head and jaguar headdress. Hollow rectangular supports. Ht. $14 \mathrm{~cm}$, diam. at rim $14 \mathrm{~cm}$, at base $13 \mathrm{~cm}$ MNA 9-2827.

2 Copa Ware vases with round hollow supports.

$1 \quad$ Matte outflaring bowl.

\section{Late Metepec La Ventilla B Burial 24}

1 Adult Male, 1 Adult Female, 1 Undetermined.

Provenience: Patio 1S, Room 4 (fig. 6).

1 Polished ring base bowl. Ht. $3.5 \mathrm{~cm}$, diam. at rim $10.5 \mathrm{~cm}$, ring base $4.5 \mathrm{~cm}$ MNA 9-2772.

1 Polished red rim interior, matte exterior deep bowl. $\mathrm{Ht} .6 \mathrm{~cm}$, diam. at rim $13.5 \mathrm{~cm}$, at base $7 \mathrm{~cm}$ MNA 9-2932.

1 Low Polish bowl with red rim "finger ridged" exterior and flared lip. Ht. $4.5 \mathrm{~cm}$, diam. at rim $13.5 \mathrm{~cm}$

1 Matte miniature ollita. Ht. $3.5 \mathrm{~cm}$, diam. at rim $3.3 \mathrm{~cm}$, at base $3 \mathrm{~cm}$

1 Low Polish miniature plate. Ht. $1.5 \mathrm{~cm}$, diam. at rim $4.6 \mathrm{~cm}$, at base $3 \mathrm{~cm}$ MNA 9-2792.

1 Low Polish Bi-pinched bowl.

2 Matte miniature ollitas with 3 handles. Ht. $5.5 \mathrm{~cm}$ and $4.5 \mathrm{~cm}$, diam. $2.5 \mathrm{~cm}$ and $2 \mathrm{~cm}$

$5 \quad$ Matte miniature bowls.

1 Matte miniature 3 prong burner. $\mathrm{Ht} .2 \mathrm{~cm}$, diam. at rim $6 \mathrm{~cm}$

1 Painted Low Polish tripod dish with flaring rim and nubbins. $\mathrm{Ht} .4 \mathrm{~cm}$, diam. at rim $13.5 \mathrm{~cm}$

$1 \quad$ Painted Red on Natural restricted bowl. Ht. $8.5 \mathrm{~cm}$, diam. at rim $9.5 \mathrm{~cm}$ 
1 Painted 3 pronged bowl or burner in red on natural with side openings. $\mathrm{Ht} .5 .5 \mathrm{~cm}$, diam. at rim $13.5 \mathrm{~cm}$

Matte bowls with "dimple" bases. Average ht. $4 \mathrm{~cm}$, diam. at rim $13.5 \mathrm{~cm}$

1 Polished outcurving bowl with nubbins, ht. $4 \mathrm{~cm}$, diam.eter $12.5 \mathrm{~cm}$

1 Matte miniature effigy, canine? $\mathrm{Ht} .2 \mathrm{~cm}$, diam. $3 \mathrm{~cm}$

1 Matte miniature scoop.

$1 \quad$ Mica disk. Length $2 \mathrm{~cm}$ spout $2 \mathrm{~cm}$ long.

1 Clay disk, diam. $5 \mathrm{~cm}$

$1 \quad$ Clay cluster

Metepec La Ventilla B Burial 34

1 Adult Male (Partial Incineration).

Provenience: Patio 6S, Room 1 (fig. 6).

1 Polished Tlaloc vase, poorly constructed. $\mathrm{Ht} .13 \mathrm{~cm}$, diam. at rim $10 \mathrm{~cm}$, diam. at base $6-7 \mathrm{~cm}$

1 Polished florero. Tube diam. 26 to $30 \mathrm{~cm}$, ht. of neck $1 \mathrm{~cm}$, diam. at rim $8 \mathrm{~cm}$, (fragment).

1 Low Polish fluted wide mouth jar. $\mathrm{Ht} .7 \mathrm{~cm}$, diam. at rim $7.5 \mathrm{~cm}$, at base $7 \mathrm{~cm}$

1 Low Polish, pattern polish interior outcurving bowl. Ht. $2 \mathrm{~cm}$, diam. at rim $13 \mathrm{~cm}$, at base $8 \mathrm{~cm}$

1 Low Polish, pattern polish interior outcurving bowl. Ht. $2.5 \mathrm{~cm}$, diam. at rim $12.5 \mathrm{~cm}$, at base $6 \mathrm{~cm}$

1 Matte miniature "finger ridged" plate. $\mathrm{Ht} .12 \mathrm{~cm}$, diam. at rim; $6.2 \mathrm{~cm}$

1 Obsidian blade.

1 Bone awl.

Metepec La Ventilla B Burial 46

1 Aged Female.

Provenience: Patio 1W west of Room 1 (fig. 6).

1 Low Polish, streak polished interior, matte exterior or outcurving bowl. Ht. $3.5 \mathrm{~cm}$, diam. at rim $14 \mathrm{~cm}$ MNA 9-4516. 
1 Copa ware vase, tan with firing clouds with scars of appliqué heads and punctate decorated band around center. $\mathrm{Ht} .6 .2 \mathrm{~cm}$, diam. at rim $13 \mathrm{~cm}$, at base $12 \mathrm{~cm}$ MNA 9-4515.

10 Matte miniature plates.

$8 \quad$ Matte miniature jars.

1 Stone ball.

Metepec La Ventilla B Burial 65

1 Young male, lacking skull.

Provenience: Patio 1 west, Room 1 (fig. 6).

1 Polished and incised flaring wall bowl with elaborate shell design. $\mathrm{Ht} .5 .3 \mathrm{~cm}$, diam. at rim $16.5 \mathrm{~cm}$, at base $12 \mathrm{~cm}$ MNA 9-2777.

1 Polished and incised flaring wall bowl with xicalcoliuhqui motif. $\mathrm{Ht} .6 .2 \mathrm{~cm}$, diam. at rim $17.9 \mathrm{~cm}$, at base $14 \mathrm{~cm}$ MNA 9-2781.

1 Polished and incised flaring bowl with intricate design. $\mathrm{Ht} .6 \mathrm{~cm}$, diam. at rim $14 \mathrm{~cm}$, at base $10 \mathrm{~cm}$ MNA 9-2934.

2 Polished and incised flaring bowls with incised motifs.

1 Polished ring base bowl. Ht. $6.2 \mathrm{~cm}$, diam. at rim $12.8 \mathrm{~cm}$, at base $6 \mathrm{~cm}$ MNA 9-1069.

1 Polished ring base bowl, small.

1 Rectangular seal, rabbit motif.

5 Moldmade figurine heads with Tlaloc attributes.

1 Figurine head, squarish face, bulbous eyes.

1 Slate disk. 


\section{BURIALS AND OFFERINGS FROM TETITLA \\ APARTMENT COMPOUND \\ (Séjourné 1966a)}

Late Tlamimilolpa Tetitla Burial 8

1 Adult male

Provenience: Entrance Southwest Patio (fig. 25; Séjourné 1966a; fig.220 )

2 Polished black gadrooned jars. $\mathrm{Ht} .7 \mathrm{~cm}$, diam. at rim $7 \mathrm{~cm}$ MNA 9-2591.

1 Thin Orange direct rim vase with double molding and cut disk adornos, traces of red pigment. Supports missing. Ht. $8 \mathrm{~cm}$, diam. at rim $12 \mathrm{~cm}$ MNA 9-2856

1 Polished yellow brown outcurving bowl, smooth groove incising, "cloud motif". Ht. $8.5 \mathrm{~cm}$, diam. at rim $25 \mathrm{~cm}$, at base $6 \mathrm{~cm}$ MNA 9-4346 2/4

Late Tlamimilolpa Tetitla Burial 17

1 Adult

Provenience: East Temple Platform, Northeast group (fig. 25)

1 Clay flute with decoration in white, yellow and black paint. Length $26 \mathrm{~cm}$, diam. $4.5 \mathrm{~cm}$ (Séjourné 1966c, fig. 120)

1 Polished black wide mouth jar. Ht. $20 \mathrm{~cm}$, diam. at rim $15 \mathrm{~cm}$

$4 \quad$ Polished low walled plates

1 Polished black florero. Ht. $12 \mathrm{~cm}$, diam. at rim $9.5 \mathrm{~cm}$

1 Polished black outcurving bowl, crudely made, with sagging base and small nubbin supports. Ht. $4 \mathrm{~cm}$, diam. at rim $13.5 \mathrm{~cm}$ MNA 9-4328 1/8

1 Low Polished black outcurving bowl with small nubbin supports. Ht. $4.5 \mathrm{~cm}$, diam. at rim $12.5 \mathrm{~cm}$ MNA 9-4328 4/8

1 Polished outcurving bowl, offset nubbins. Ht. $4 \mathrm{~cm}$, diam. at rim $13 \mathrm{~cm}$

1 Polished outcurving bowl with everted rim. Ht. $9 \mathrm{~cm}$, diam. at rim $12.5 \mathrm{~cm}$ MNA 9-2917

$1 \quad$ Polished miniature cazuela

4 Matte miniature bowls. MNA 9-4788

1 Matte incensario ornament

1 Stone tiger chacmool (Séjourné 1966c, fig. 181A) 
1 Stone seated figure, brasero (Séjourné 1966c, fig. 189)

$4 \quad$ Obsidian blades

$2 \quad$ Pieces mica

Slate fragments with red motifs

Late Tlamimilolpa Tetitla Burial 31

Age, sex unknown

Provenience: Patio, Northeast Temple patio (fig. 25; Séjourné 1966a, fig. 220)

1 Polished brown deep grooved jar with short neck. Ht. $11.7 \mathrm{~cm}$, body diam. $11.7 \mathrm{~cm}$, neck diam. $9.2 \mathrm{~cm}$ MNA 9-2975

\section{$\underline{\text { Tetitla Offerings }}$}

Late Tlamimilolpa Tetitla Offering 21

Provenience: Small corridor north central part of compound (fig. 25)

1 Painted nonspecular red on natural outcurving bowl with round hollow supports. Ht. $9.2 \mathrm{~cm}$, diam. at rim $26 \mathrm{~cm}$ MNA $9-43461 / 4$

1 Polished light brown outcurving bowl, blackened base. $\mathrm{Ht} .7 \mathrm{~cm}$, diam. $31.5 \mathrm{~cm}$ MNA 9-4363 10/19

1 Polished brown outcurving bowl with fine line incising, "cloud" motif. Ht. $6.5 \mathrm{~cm}$, diam. at rim $28 \mathrm{~cm}$, at base $19 \mathrm{~cm}$ MNA 9-4363 19/19

1 Polished brown outcurving bowl. Ht. $6 \mathrm{~cm}$, diam. at rim $22.5 \mathrm{~cm}$, at base $14 \mathrm{~cm}$ MNA 9-4363 18/19

1 Polished dark brown outcurving bowl with wide cut incised "cloud" motif. Ht. $8.8 \mathrm{~cm}$, diam. at rim $28.5 \mathrm{~cm}$, at base $17.5 \mathrm{~cm}$ MNA 9-4363 6/19

1 Streak polished and matte bowl. Ht. $2.5 \mathrm{~cm}$, diam. $13.5 \mathrm{~cm}$

1 Matte 3-handled cover. Ht. $7.5 \mathrm{~cm}$, diam. $25 \mathrm{~cm}$

1 Matte 3-handled cover. Ht. $6 \mathrm{~cm}$, diam. $22 \mathrm{~cm}$

1 Puppet figurine, large. Possible Xipe. Ht. $40 \mathrm{~cm}$, diam. $20 \mathrm{~cm}$ (Séjourné 1966a: Lam 57)

1 Puppet torso, small. Ht. $12 \mathrm{~cm}$, diam. $7 \mathrm{~cm}$ 
Late Tlamimilolpa Tetitla Offering 61

Provenience: Outside northeast wall (fig. 25)

1 Painted specular red on natural, "ray" motif outlined by incising, outcurving bowl with conical nubbins. Ht. $4.5 \mathrm{~cm}$; diam. at rim $22 \mathrm{~cm}$, at base $15 \mathrm{~cm}$ MNA 9-2696.

\section{Early Xolalpan Burials}

Early Xolalpan Tetitla Burial 4

Age sex unknown

Provenience: Patio, Northeast Temple group (fig. 25)

1 Copa ware copa with handle in brown on brown resist. $\mathrm{Ht} .12 .4 \mathrm{~cm}$, diam. at rim $8 \mathrm{~cm}$, at base $5 \mathrm{~cm}$ MNA 9-2990.

1 Polished incised flaring bowl. Ht. $6.5 \mathrm{~cm}$, diam. at rim $18 \mathrm{~cm}$

10 Painted specular red small plates. Ht. $2.2 \mathrm{~cm}$, diam. $9.2 \mathrm{~cm}$ (1 burnt). MNA 9-4785 4/10

3 Matte miniature flaring plates

$1 \quad$ Matte miniature dish

1 Figurine, seated, hand modeled. Ht. $6 \mathrm{~cm}$, diam. $2 \mathrm{~cm}$

\section{Early Xolalpan Tetitla Burial 7}

1 Adult, sex unknown

Provenience: East Room, northeast part of compound (fig. 25)

1 Polished outcurving bowl with flush nubbin supports, streak polished exterior. $\mathrm{Ht} .4 \mathrm{~cm}$, diam. at rim $14.5 \mathrm{~cm}$ MNA 9-4529

Early Xolalpan Tetitla Burial 16

2 Male adults

Provenience: East Platform, Northeast Temple group (fig. 25)

1 Burnished orange jar, dense paste, with everted rim, lower part unburnished. $\mathrm{Ht} .21 \mathrm{~cm}$, diam. at rim $18 \mathrm{~cm}$ MNA 9-2627 (Séjourné 1966a: Lam. 55)

1 Polished wide mouth jar with offset nubbins, everted rim. $\mathrm{Ht} .7 \mathrm{~cm}$, diam. $8.5 \mathrm{~cm}$ MNA 9-4309

1 Polished wide mouth jar with flush nubbins. Ht. $17 \mathrm{~cm}$, diam. $18.5 \mathrm{~cm}$ MNA 9-2961

1 Polished wide mouth jar, flat base. Ht. $13 \mathrm{~cm}$, diam. $16 \mathrm{~cm}$ MNA 9-4343 3/5 
1 Polished outcurving bowl with flush nubbins and finely executed "pattern polish" design on outside. Ht. $5.1 \mathrm{~cm}$, diam. at rim $15 \mathrm{~cm}$ MNA 9-4344 4/4

1 Polished black outcurving bowl with flush nubbins. Ht. $3.5 \mathrm{~cm}$, diam. $12 \mathrm{~cm}$ MNA 9-4328 9/8

$1 \quad$ Polished black outcurving bowl, small

1 Polished outcurving bowl with nubbins. Ht. $5.1 \mathrm{~cm}$, diam. at $\operatorname{rim} 14 \mathrm{~cm}$, at base $8.5 \mathrm{~cm}$ MNA 9-4528

1 Coarse Matte censer bowl. Ht. $8.5 \mathrm{~cm}$, diam. at rim $21 \mathrm{~cm}$

1 Matte plate. Ht. $2 \mathrm{~cm}$, diam. $6.4 \mathrm{~cm}$ MNA 9-4791

$1 \quad$ Matte plate. Ht. $1.6 \mathrm{~cm}$, diam. $7.7 \mathrm{~cm}$ MNA 9-4799

$1 \quad$ Matte plate. Ht. $2.5 \mathrm{~cm}$, diam. $8.9 \mathrm{~cm}$

$2 \quad$ Matte simple dishes. Ht. $2.5 \mathrm{~cm}$, diam. $11.5 \mathrm{~cm}$ MNA 9-4307

1 Matte plate. Ht. $1 \mathrm{~cm}$, diam. $11 \mathrm{~cm}$

100+ Obsidian blades

$1 \quad$ Obsidian projectile point; 1 obsidian eccentric

3 Fragments mica

$1 \quad$ Bone awl

Early Xolalpan Tetitla Burial 26

1 Adult female

Provenience: Long north central room (fig. 25)

1 Copa ware cylindrical vase with basal torus, molded supports and incised scroll design (Séjourné 1966a, Lam. 24).

1 Polished outcurving bowl, light brown, poorly made. Ht. $4.8 \mathrm{~cm}$, diam. at rim $15 \mathrm{~cm}$ at base, $9 \mathrm{~cm}$ MNA $9-4300 / 5$

1 Polished outcurving bowl with rounded base angle in yellowish brown. $\mathrm{Ht} .5 \mathrm{~cm}$, diam. at rim $16 \mathrm{~cm}$ MNA 9-4307/8

2 Obsidian projectile points

$1 \quad$ String obsidian beads 


\section{Early Xolalpan Tetitla Burial 27}

\section{Adult male}

Provenience: East inner room, North central unit (fig. 25)

1 Polished outcurving bowl with nubbin supports. $\mathrm{Ht} .7 \mathrm{~cm}$, diam. at rim $28 \mathrm{~cm}$ MNA 9-2972

1 Polished wide mouth jar with nubbin supports. $\mathrm{Ht} .17 \mathrm{~cm}$, diam. $18 \mathrm{~cm}$ (Séjourné 1966a, Lam. 34)

1 Thin Orange ring base bowl with "crack-lacing". $\mathrm{Ht} .7 \mathrm{~cm}$, diam. at rim $21 \mathrm{~cm}$

\section{Early Xolalpan Tetitla Burial 32}

Adult, sex unknown

Provenience: Plaza,Northeast Temple group (fig. 25)

1 Thin Orange ring base bowl, undecorated. Ht. $4.4 \mathrm{~cm}$, diam. $13 \mathrm{~cm}$ MNA 9-3001

1 Thin Orange ring base bowl with incised $\mathrm{S}$ design, bordered by round punctate. Ht. $8.2 \mathrm{~cm}$, diam. $20 \mathrm{~cm}$ MNA 9-2996

1 Granular ware Strombus shell trumpet. Length $28 \mathrm{~cm}$, diam. $13 \mathrm{~cm}$ (Séjourné 1959: fig. 182)

1 Tlaloc jar. Ht. $19 \mathrm{~cm}$, diam. $13 \mathrm{~cm}$ MNA 9-2945

1 Florero, diagonally grooved body. $\mathrm{Ht} .12 .9 \mathrm{~cm}$, diam. at rim $8.3 \mathrm{~cm}$, at base $5 \mathrm{~cm}$ MNA 9-2588

11 Matte miniatures, bowls and plates. Average height 1 to $2 \mathrm{~cm}$, diam. 5 to $8 \mathrm{~cm}$ MNA 9-2756. MNA 4794

1 Matte miniature 3-handled cover with tabs. Ht. $2 \mathrm{~cm}$, diam. $11 \mathrm{~cm}$

1 Matte miniature florero. Ht. $6 \mathrm{~cm}$, diam. $4 \mathrm{~cm}$

1 Copa ware vase, dark brown with hollow round supports. $\mathrm{Ht} .12 \mathrm{~cm}$, diam. at rim $11.5 \mathrm{~cm}$, at base $10.5 \mathrm{~cm}$ MNA 9-2972

1 Polished upright bowl. Ht. $6 \mathrm{~cm}$, diam. at rim $18 \mathrm{~cm}$ MNA 9-4355 2/4

\section{Early Xolalpan Tetitla Offerings}

Early Xolalpan Tetitla Offering 5

Provenience: Room east of 4-Temple complex (fig. 26)

1 Matte handleless cover. Ht. $5 \mathrm{~cm}$, diam. at rim $26.5 \mathrm{~cm}$ MNA 9-2926 
1 Polished outcurving bowl, slightly warped. diam. at rim $28 \mathrm{~cm}$, at base $17 \mathrm{~cm}$, ht. $5 \mathrm{~cm}$ MNA 698 (Ibid, fig. 161b)

1 Painted bichrome red on brown incurved hemispherical bowl. $\mathrm{Ht} .4 \mathrm{~cm}$, diam. at rim $9 \mathrm{~cm}$ (Séjourné 1966a, fig. 161c)

\section{Early Xolalpan Tetitla Offering 17}

Provenience: Portico north of Southeast Altar patio (fig. 25)

1 Burnished large red rim olla with tall globular body. Ht. $36 \mathrm{~cm}$, diam. at rim $29 \mathrm{~cm}$ MNA, Teotihuacan Room

$1 \quad$ Polished flaring dish with offset nubbins

Early Xolalpan Tetitla Offering 24

Provenience: Passageway between southwest entrance and Armillas' excavation (fig. 25)

1 Polished cylindrical vase with everted rim, nubbin supports and horizontal incising. Enormous size: Ht. $41 \mathrm{~cm}$, diam. at rim $38 \mathrm{~cm}$ (Ibid Lam. 59b) MNA Teotihuacan Room

1 Polished ring or pedestal base bowl (base broken) in Copa-like ware in dark brown. Ht. $20 \mathrm{~cm}$, diam. at rim $24 \mathrm{~cm}$ (Ibid, Lam. 36, 59a). MNA 9-2556, Tetotihuacan Room

Early Xolalpan Tetitla Offering 26

Provenience: Room, southwest corner of compound (fig. 25)

1 Polished, plano-relief decorated vase with pictorial design. Ht. $24 \mathrm{~cm}$, diam. $29.5 \mathrm{~cm}$ MNA, Teotihuacan Room

Early Xolalpan Tetitla Offering 32

Provenience: Main northeast patio (fig. 25)

1 Coarse Matte incensario lid decorated with molmade ornaments (plaques, flowers, disks, feathers) surrounding a central face mask and set on a censer base. Lid measurements: width, $26-40 \mathrm{~cm}$, ht. $70 \mathrm{~cm}$ MNA 9-4592

Early Xolalpan Tetitla Offering 34

Provenience: Level 3, South innerroom, Southwest 3-Temple group (fig. 25)

1 Candelero with incised decoration 
1 Coarse Matte incensario base. Ht. $18 \mathrm{~cm}$, diam. $38 \mathrm{~cm}$

1 Coarse Matte incensario base. $\mathrm{Ht} .18 \mathrm{~cm}$, diam. $42.5 \mathrm{~cm}$

Early Xolalpan Tetitla Offering 35

Provenience: Patio of southwest 3 - Temple group (fig. 25)

1 Copa-like vase with hollow round supports wiht rattles. $\mathrm{Ht} .9 .5 \mathrm{~cm}$, diam. at $\operatorname{rim} 12.6 \mathrm{~cm}$ at base $11.5 \mathrm{~cm}$ MNA 9-4323

1 Matte incensario top with handles and oval chimney. (Censer base originally in two parts has been reconstructed with two parts joined). Wide border flanges on both. Maximum overall diameter $40 \mathrm{~cm}$, ht. $68 \mathrm{~cm}$

1 Matte painted red and yellow mask. Width $16.7 \mathrm{~cm}$, ht. $14 \mathrm{~cm}$

Early Xolalpan Tetitla Offering 41

Provenience: Level 3, North inner room, southwest 3-Temple group (fig. 25)

$1 \quad$ Matte composite censer composed of 3 parts: a conical stand; a "flower pot" intermediate section with wide flange; and lid decorated with moldmade adornos surrounding a central mask. Width $36.5 \mathrm{~cm}$, ht. $59 \mathrm{~cm}$ MNA 9-3377

\section{Early Xolalpan Offerings}

Early-Late Xolalpan Tetitla Offering 57

Provenience: Northeast Annex, outside main wall (fig.25; Séjourné 1966a, fig. 220)

1 Fine Matte simple plate with matte exterior, streak polished interior. $\mathrm{Ht} .4 \mathrm{~cm}$, diam. at rim $16.5 \mathrm{~cm}$ MNA 9-4350

1 Coarse Matte incensario base with wide flange and gouge-incised conical lid

Early Xolalpan Tetitla Offering 62

Provenience: Extreme north central room (fig. 25)

1 Matte composite incensario composed of a lid with chimney and frame, decorated with moldmade ornaments (plaques, flowers, butterflies, quetzal birds and feathers).

MNA 9-3370 (Ibid, Lam. 63 shows incensario at time of discovery) 
Late Xolalpan Burials

Late Xolalpan Tetitla Burial 5

Age, sex unknown

Provenience: Patio of main northeast temple group 14.

Matte miniature ollitas. Average size: ht. $4.1 \mathrm{~cm}$, diam. $4.6 \mathrm{~cm}$

7 Matte miniature dishes with dimpled bases. diam. 3-4 cm

Late Xolalpan Tetitla Burial 9

1 Adult, sex unknown

Provenience: East Platform, Northeast Temple group (fig. 25)

1 Tlaloc jar, light brown, moderately well polished. $\mathrm{Ht} .20 \mathrm{~cm}$, diam. at rim $20 \mathrm{~cm}$, base $8 \mathrm{~cm}$ MNA 9-3005 (Ibid, fig. 191)

1 Thin Orange flaring neck jar, globular body, flat base. Ht. $20.5 \mathrm{~cm}$, diam. at rim $15.7 \mathrm{~cm}$, base $11.5 \mathrm{~cm}$ MNA $9-4526$

1 Copa ware vase with basal torus and molded slab supports; matching incised lid with bird handle. Vase ht. $15 \mathrm{~cm}$, diam. $14 \mathrm{~cm}$ MNA 9-2931 (Ibid, fig. 204, 396)

1 Copa ware vase with basal flange, molded heads and molded slab supports. $\mathrm{Ht} .12 .9 \mathrm{~cm}$, diam. at rim $13.5 \mathrm{~cm}$, base $11.9 \mathrm{~cm}$ MNA 9-3003 (Ibid, fig. 200)

1 Copa ware copa in light brown. Ht. $9 \mathrm{~cm}$, diam. at rim $6 \mathrm{~cm}$, base $4 \mathrm{~cm}$ MNA 2930

1 Polished black recurved bowl with fine parallel incised lines, flared rim. $\mathrm{Ht} .6 .4 \mathrm{~cm}$, diam. at rim $19.5 \mathrm{~cm}$, base $13 \mathrm{~cm}$ MNA 9-4418

2 Polished light brown recurved bowl. Ht. $6.2 \mathrm{~cm}$ to $6.4 \mathrm{~cm}$, diam. at rim $19 \mathrm{~cm}$, base $11 \mathrm{~cm}$ MNA 9-4525 2/2

1 Polished black upright bowl. Ht. $5 \mathrm{~cm}$, diam. at rim $13.7 \mathrm{~cm}$, base $8 \mathrm{~cm}$ MNA 9-4418

1 Polished black upright bowl with fine incising and simple direct rim. $\mathrm{Ht} .6 .5 \mathrm{~cm}$, diam. at rim $20.2 \mathrm{~cm}$, base $13 \mathrm{~cm}$ MNA 9-4418

1 Polished dark brown recurved bowl. Ht. $5 \mathrm{~cm}$, diam. at rim $13.5 \mathrm{~cm}$, base $7.5 \mathrm{~cm}$ MNA 9-4360 2/15

1 Polished dark brown outcurving bowl with "pattern polish" design interior. $\mathrm{Ht} .3 .4 \mathrm{~cm}$, diam. at rim $14.8 \mathrm{~cm}$, base $9 \mathrm{~cm}$ MNA 9-4360 10/15

1 Streak polished light brown outcurving bowl. Ht. $36 \mathrm{~cm}$, diam. at rim $16.5 \mathrm{~cm}$, base $10 \mathrm{~cm}$ MNA 9-4360 13/15 
3 Painted recurved specular red bowls. Ht. 2.2-2.4 cm, diam. at rim $10.4 \mathrm{~cm}$, base $8 \mathrm{~cm}$ MNA 9-4355 3/4, $1 / 4$

1 Polished brown outcurving bowl with nubbin supports. MNA 9-4328 3/8

1 Polished brown outcurving bowl with nubbin supports. MNA 9-4328 3/8

200 Matte miniature jars

$2 \quad$ Matte miniature floreros

170 Matte miniature dimpled dishes

17 Matte miniature upcurved bowls

12 Matte miniature simple dishes

$2 \quad$ Matte miniature flaring bowls

1 Matte miniature cover-plate (tapaplato)

$1 \quad$ Matte miniature plate

1 Necklace of dentalium. Length $49.5 \mathrm{~cm}$, width $40 \mathrm{~cm}$

Late Xolalpan Tetitla Burial 12

Age, sex unknown

Provenience: Northeast side room, Northeast Patio group (fig.25; Séjourné 1966a, fig. 220)

1 Polished tan cylindrical vase with double basal molding and bird-serpent head adornos and bud-like supports with rattles. Ht. $14 \mathrm{~cm}$, diam. $15 \mathrm{~cm}$ MNA 9-2970

1 Polished wide mouth jar wiht pattern polished neck. Ht. $14.8 \mathrm{~cm}$, diam. $16 \mathrm{~cm}$ MNA 9-4333 4/5

1 Polished wide mouth jar with pattern polished neck. $\mathrm{Ht} .13 \mathrm{~cm}$, diam. at rim $14.5 \mathrm{~cm}$ MNA 9-4335/5

$1 \quad$ Matte outcurving bowl. Ht. $2.5 \mathrm{~cm}$, diam. $13.5 \mathrm{~cm}$

\section{Late Xolalpan Tetitla Burial 14}

1 Adult, sex unknown

Provenience: South room, west central patio group (fig. 25)

1 Polished Tlaloc jar. Ht. $16 \mathrm{~cm}$, diam. at rim $16 \mathrm{~cm}$

1 Polished light brown Tlaloc jar. Ht. $17 \mathrm{~cm}$, diam. at rim $16.5 \mathrm{~cm}$ 
1 Cylindrical vase, stucco-painted, marching Teotihuacan personage, with openwork support. Ht. 14 cm, diam. $16 \mathrm{~cm}$ MNA Teotihuacan Room (Séjourné 1966a, Lam. 32)

1 Thin Orange bowl with ring base. Ht. $6 \mathrm{~cm}$, diam. at rim $20 \mathrm{~cm}$, base $7.5 \mathrm{~cm}$ MNA 9-4340 1/3

1 Thin Orange bowl with ring base. Ht. $6 \mathrm{~cm}$, diam. at rim $16.5 \mathrm{~cm}$ MNA 9-2997

$2 \quad$ Thin Orange bowl with ring base. Ht. $5.5 \mathrm{~cm}$, diam. at rim $16.5 \mathrm{~cm}$

1 Polished light brown outcurving bowl. $\mathrm{Ht} .3 \mathrm{~cm}$, diam. at rim. $15.5 \mathrm{~cm}$, base $10.9 \mathrm{~cm}$ MNA 9-4360 14/15

1 Polished dark brown upright bowl. Ht. $4.5 \mathrm{~cm}$, diam. at rim $16.5 \mathrm{~cm}$, base $10.5 \mathrm{~cm}$ MNA 9-2954

1 Polished reddish brown corrugated vase with hollow cylindrical supports. $\mathrm{Ht} .7 .8 \mathrm{~cm}$, diam. at rim $13.2 \mathrm{~cm}$ MNA 9-2959

1 Matte miniature handled cover

1 Matte miniature comal. Ht. $1 \mathrm{~cm}$, diam. $8.5 \mathrm{~cm}$

1 Red miniature matte simple bowl. Ht. $1.5 \mathrm{~cm}$, diam. $7 \mathrm{~cm}$

1 Matte miniature simple dish. Ht. $.5 \mathrm{~cm}$, diam. $3.5 \mathrm{~cm}$

1 Matte miniature florero. Ht. $4 \mathrm{~cm}$, diam. $4 \mathrm{~cm}$

8 bone tools (needles and awls)

5 obsidian blades, 1 obsidian scraper

1 clay cone

6 mica fragments

Stone object

Late Xolalpan Tetitla Burial 15

1 Adult, sex unknown

Provenience: South room of central patio (fig. 25)

1 Polished cylindrical vase with molded adornos around the basal flange and bud-like supports. Ht. $8 \mathrm{~cm}$, diam. at rim $17 \mathrm{~cm}$ MNA 8-2958 (Séjourné 1966a, Lam. 18, 25)

1 Stucco-painted vase with hollow rectangular openwork supports (Séjourné 1966a, fig. 93, Lam. 25 upper right, 31)

1 Thin Orange recurved bowl with ring base and border of double punctate decoration. 
Ht. $5.3 \mathrm{~cm}$, base $7.2 \mathrm{~cm}$ MNA 9-2864 (Séjourné 1966a, Lam. 25, lower left)

$1 \quad$ Polished outcurving bowl, poor finish. Ht. $3.5 \mathrm{~cm}$, diam. $15.5 \mathrm{~cm}$ MNA 9-2984

1 Polished outcurving bowl with streak polished exterior. $\mathrm{Ht} .4 \mathrm{~cm}$, diam. at rim $16.2 \mathrm{~cm}$, at base $10.5 \mathrm{~cm}$ MNA 9-2983

1 Polished outcurving bowl. Ht. $3 \mathrm{~cm}$, diam. at rim $13.5 \mathrm{~cm}$

2 Matte miniature jars. Ht. $3 \mathrm{~cm}$, diam. $3.5 \mathrm{~cm}$

1 Thin Orange gadrooned jar with flaring neck and everted rim. Ht. $14 \mathrm{~cm}$, diam. $16 \mathrm{~cm}$ (Séjourné 1966a, fig. 140, Lam. 40)

1 Obsidian blade

Late Xolalpan Tetitla Burial 18

Age, sex unknown

Provenience: Patio, SoutheastTemple group (fig. 25)

1 Thin Orange cylindrical vase with tab supports and incised and comb punctate decoration. Ht. $7.5 \mathrm{~cm}$, diam. $9 \mathrm{~cm}$ at rim, $6.8 \mathrm{~cm}$ at base. MNA 9-2860 (Séjourné 1966a: Lam. 30)

1 San Martin Orange crater with everted rim. Ht. $14 \mathrm{~cm}$, diam. $24 \mathrm{~cm}$

1 Polished obtuse angle outcurving bowl with flat base. $\mathrm{Ht} .2 .5 \mathrm{~cm}$ diam. at rim $16 \mathrm{~cm}$

$1 \quad$ Zone Polished wide mouth jar. Ht. $14.5 \mathrm{~cm}$, diam. $14.5 \mathrm{~cm}$

1 Polished outcurving bowl (incomplete). Ht. $2.5 \mathrm{~cm}$, diam. $16.5 \mathrm{~cm}$

1 Polished outcurving bowl. Ht. $3 \mathrm{~cm}$, diam. $16 \mathrm{~cm}$

$4 \quad$ Fine Matte miniature ollitas. Ht. 3 to $4 \mathrm{~cm}$, diam. 3.5 to $4.5 \mathrm{~cm}$

1 Fine Matte miniature plate. Ht. $5 \mathrm{~cm}$, diam. $5 \mathrm{~cm}$

5 Fine Matte miniature simple plates. Ht. 6 to $8 \mathrm{~cm}$, diam. 5 to $5.5 \mathrm{~cm}$

1 Matte miniature ollita. Ht. $1.4 \mathrm{~cm}$, diam. $1.4 \mathrm{~cm}$

1 Copa ware cylindrical vase with moldmade supports and molded heads around basal flange (Ibid, Lam. 30, upper right) 
Late Xolalpan Tetitla Burial 19

Age, sex unknown

Provenience: Patio of southeast temple group (fig. 25)

1 Polished outcurving bowl. Ht. $5.2 \mathrm{~cm}$, diam. at rim $17.3 \mathrm{~cm}$, at base $10.5 \mathrm{~cm}$ MNA 9-4360 $16 / 16$

Late Xolalpan Tetitla Burial 20

1 Adult male

Provenience: North portico, Southwest group (fig. 25)

$1 \quad$ Polished jar with "vague" neck. $\mathrm{Ht} .17 \mathrm{~cm}$, diam. at base $14.2 \mathrm{~cm}$ (rim broken). MNA 9-4333 2/5

1 Polished miniature low neck outcurving jar with 3 loop handles. Ht. $8 \mathrm{~cm}$, diam. $6 \mathrm{~cm}$

Late Xolalpan Tetitla Burial 28

1 Adult

Provenience: East portico,north central patio group (fig. 25)

1 Stucco-painted light green on black vase with, cutout hollow rectangular supports with rattles inside. Ht. $13.4 \mathrm{~cm}$ with supports, diam. at rim $15 \mathrm{~cm}$ at base $13.5 \mathrm{~cm}$

MNA 9-2753 (Ibid, Lam. 33, fig. 90)

3 Thin Orange channelled flaring recurved bowl with annular base. $\mathrm{Ht} .4 \mathrm{~cm}$, diam. $13 \mathrm{~cm}$

1 Polished outcurving bowl with pattern polished interior. $\mathrm{Ht} .2 .5 \mathrm{~cm}$, diam. $13 \mathrm{~cm}$

1 Fine Matte miniature 3-handled cover. $\mathrm{Ht} .7 \mathrm{~cm}$, diam. $2.5 \mathrm{~cm}$

3 Fine Matte miniature dimpled base dish. Ht. $1.6 \mathrm{~cm}$, diam. $6.5 \mathrm{~cm}$

4 Fine Matte miniatures, wide mouth jars. Ht. $3.5 \mathrm{~cm}$, diam. $4.5 \mathrm{~cm}$

1 Figurine hand made. Ht. $2.5 \mathrm{~cm}$, diam. $2 \mathrm{~cm}$

1 Figurine mold, broken. $\mathrm{Ht} .2 \mathrm{~cm}$, width $7 \times 5 \mathrm{~cm}$ 
Late Xolalpan Tetitla Offerings

Late Xolalpan Tetitla Offering 9

Provenience: Patio, North Central group (fig. 26)

1 Zone Polished and incised cylindrical vase (supports incorrectly reconstructed). $\mathrm{Ht} .8 \mathrm{~cm}$, diam. at rim $16 \mathrm{~cm}$, at base $14 \mathrm{~cm}$ MNA 9-3002

1 Painted, incised red on brown cylindrical vase with wide incised basal molding and hollow cylindrical supports. Ht. $17.5 \mathrm{~cm}$, diam. $18 \mathrm{~cm}$ MNA 9-2828

1 Polished cylindrical vase with hollow rectangular support scars.

Late Xolalpan Tetitla Offering 19

Provenience: Central part of compound (fig. 25)

1 Polished outcurving bowl, polished interior, matte exterior rim, pattern polished base. Ht. $6.8 \mathrm{~cm}$, diam. at rim $30 \mathrm{~cm}$, at base $17 \mathrm{~cm}$ MNA 9-4363

1 Polished outcurving bowl indark gray. Pattern polish bottom. Ht. $7 \mathrm{~cm}$, diam. at rim $29.5 \mathrm{~cm}$, at base $17 \mathrm{~cm}$ MNA 9-4363

Late Xolalpan Tetitla Offering 20

Provenience: West room of east central group (fig. 25)

1 Polished tan Tlaloc jar. Ht. $16.4 \mathrm{~cm}$, diam. at rim $12 \mathrm{~cm}$, at base $6 \mathrm{~cm}$ MNA 9-2941 (Séjourné 1966a, Lam. 27)

3 Polished tan miniature Tlaloc jars. $\mathrm{Ht} .7 .5 \mathrm{~cm}$, diam. $5 \mathrm{~cm}$ (originally triple vessel)

1 Coarse Matte incensario base in 2 parts.

1 Coarse Matte flanged censer base with white paint. Ht. $11.5 \mathrm{~cm}$, diam. at rim $2.5 \mathrm{~cm}$ MNA 9-2943

Late Xolalpan Tetitla Offering 23

Provenience: Isolated room in southwest of compound (fig. 25)

$1 \quad$ Matte incensario in three parts: stand, base and lid. Lid adorned with face mask surrounded by quetzal birds, feathered disks and butterflies rest on 2 part censer base with wide curved flange. 
Late Xolalpan Tetitla Offering 28

Provenience: South room group, west of Armillas' excavation (fig. 25)

1 Thin Orange hemispherical bowl with ring base (very worn). $\mathrm{Ht} .12 \mathrm{~cm}$, diam. at rim $31.2 \mathrm{~cm}$ MNA 9-2992

1 Polished outcurving bowl with flat base. $\mathrm{Ht} .7 \mathrm{~cm}$, diam. at rim $33.5 \mathrm{~cm}$

Late Xolalpan Tetitla Offering 29

Provenience:Outer wall of compound at southwest corner(fig. 25)

1 Matte incensario in three parts: stand, base and lid. Flanged censer bowl. $\mathrm{Ht} .9 \mathrm{~cm}$, diam. $23 \mathrm{~cm}$, overall ht. approx. $60 \mathrm{~cm}$

1 Polished outcurving bowl, thick walled. Ht. $6 \mathrm{~cm}$, diam. $28.5 \mathrm{~cm}$ MNA 9-4363

1 Polished outcurving bowl, thick-walled. Ht. $6 \mathrm{~cm}$, diam. $28 \mathrm{~cm}$ MNA 9-4363

Late Xolalpan Tetitla Offering 30

Provenience: Northeast Temple group (fig. 25)

1 Matte incensario in 2 parts, base and lid with backdrop and seated figure

1 Polished outcurving bowl, obtuse angled base, slightly rounded, thick walled. $\mathrm{Ht} .5 \mathrm{~cm}$, diam. at rim $26 \mathrm{~cm}$, at base $15.5 \mathrm{~cm}$ MNA 9-4363

1 San Martin Orange crater. Ht. $13.5 \mathrm{~cm}$, diam. $24 \mathrm{~cm}$

Late Xolalpan Tetitla Offering 63

Provenience: North room of main north patio (fig. 25)

$1 \quad$ Polished fluted cylindrical vase with basal flange and cut disk adornos. Supports are bud-like. Ht. $11.5 \mathrm{~cm}$, diam. at rim $13 \mathrm{~cm}$ (Ibid, fig. 68a)

1 Polished brown recurved bowl. $\mathrm{Ht} .5 \mathrm{~cm}$, diam. at rim $12.5 \mathrm{~cm}$

1 Fine Matte miniature florero. $\mathrm{Ht} .7 \mathrm{~cm}$, diam. at rim $5.5 \mathrm{~cm}$

1 Fine Matte miniature 3 handled cover. $\mathrm{Ht} .3 \mathrm{~cm}$, diam. at rim $11.5 \mathrm{~cm}$

1 Fine Matte miniature simple bowl. Ht. $1 \mathrm{~cm}$, diam. $2 \mathrm{~cm}$ 


\section{Metepec Tetitla Burials}

Metepec Tetitla Burial 2

Age, sex unknown

Provenience: Patio, Northeast Temple group (fig. 25)

1 Copa ware cylindrical vase with crude "serpent $X "$ motif in pseudo plano-relief technique. Ht. $11 \mathrm{~cm}$, diam. $11.5 \mathrm{~cm}$ MNA 9-3004 (Ibid, fig. 36 bottom, 43, Lam. 28)

1 Polished upright bowl, streaky finish. Ht. $5 \mathrm{~cm}$, diam. at rim $15 \mathrm{~cm}$, at base $10.5 \mathrm{~cm}$ MNA 9-4360 11/15

1 Polished upright bowl wiht allover polish. Ht. $5 \mathrm{~cm}$, diam. at rim $15.5 \mathrm{~cm}$, at base $9 \mathrm{~cm}$ MNA 9-2953

3 Polished upright bowls with stick polished interiors. $\mathrm{Ht} .2 \mathrm{~cm}$, diam. at rim $5.5 \mathrm{~cm}$ to $5.8 \mathrm{~cm}$

1 Polished ring base bowl. Ht. $5 \mathrm{~cm}$, diam. at rim $16 \mathrm{~cm}$

3 Polished simple bowls. Ht. $1.9 \mathrm{~cm}$ to $2 \mathrm{~cm}$, diam. at rim $5.5 \mathrm{~cm}$ to $5.6 \mathrm{~cm}$

1 Polished upright bowl. Ht. $4 \mathrm{~cm}$, diam. at rim $12 \mathrm{~cm}$ MNA 9-2953

15 Fine Matte miniature jars. Ht. 3 to $4 \mathrm{~cm}$, diam. 3.5 to $4 \mathrm{~cm}$

$1 \quad$ Polished Tlaloc jar. Ht. $16.5 \mathrm{~cm}$, diam. $19.5 \mathrm{~cm}$ (Ibid, Lam. 1, 28)

2 Funerary masks: (1) $9.5 \mathrm{~cm}$ high by $11.6 \mathrm{~cm}$ wide (2) $9.5 \mathrm{~cm}$ high by $12 \mathrm{~cm}$ wide

32 Clay earpools (moldmade censer type)

2 Palettes

$1 \quad$ Mica disk

1 Shell object

Matte miniatures

\section{Metepec Tetitla Burial 3}

Age, sex unknown

Provenience: Patio Northeast Temple group (fig. 25)

1 Zone Polished upright bowl. diam. $21 \mathrm{~cm}$, ht. $7.5 \mathrm{~cm}$ MNA 9-2978

1 Polished diagonally grooved upright bowl. diam. at rim $24 \mathrm{~cm}$, at base $16 \mathrm{~cm} \mathrm{Ht.} 8 \mathrm{~cm}$ MNA 9-2977 
1 Polished upright bowl, streaky finish. diam. at rim $16.7 \mathrm{~cm}$, diam. at base $9.5 \mathrm{~cm}$, ht. $5.7 \mathrm{~cm}$ MNA $9-4360$

1 Polished flaring bowl. diam. $14 \mathrm{~cm}$, ht. $5 \mathrm{~cm}$ MNA 9-3010

1 Polished flaring bowl. diam. $10 \mathrm{~cm}$, ht. $5.5 \mathrm{~cm}$ MNA 9-3011

1 Polished incised short neck flaring rim jar. diam. at rim $8 \mathrm{~cm}$, ht. $10 \mathrm{~cm}$ MNA 9-2609

1 Painted specualr red upright bowl. MNA 9-4534

13 Fine Matte miniature jars

6 Fine Matte miniature dishes

$9 \quad$ Fine Mate miniature "dimpled base" dishes

$4 \quad$ Painted miniature red on brown plates

2 Clay paint palettes. Width $6 \mathrm{~cm}$, ht. $16 \mathrm{~cm}, 16.5 \mathrm{~cm}$

1 Puppet figurine with hollow torso. Width $15 \mathrm{~cm}$, ht. $39.5 \mathrm{~cm}$

Metepec Burial 6, Tetitla Compound

Age, sex unknown

Provenience: East Platform, east central part (fig. 25).

1 Polished everted rim vase with offset nubbins. Diam. $10 \mathrm{~cm}, \mathrm{ht} .7 \mathrm{~cm}$

1 Copa ware squat copa. Diam. $8 \mathrm{~cm}$, ht. $6.5 \mathrm{~cm}$

1 Fine Matte cover with loop handles. diam. $16.8 \mathrm{~cm}$, ht. $4.2 \mathrm{~cm}$ MNA 9-4358

21 Fine Matte miniature wide mouth jars

$4 \quad$ Fine Matte miniature dishes

$1 \quad$ Fine Matte "dimpled base" dish

$1 \quad$ Fine Matte shallow dish

$2 \quad$ Clay masks

Metepec Burial 10, Tetitla Compound

1 Adult male

Provenience: East Platform, Northeast Temple group (fig. 25) 
1 Polished plano-relief cylindrical vase with round hollow supports. Geometric, symbolic designs (Ibid, Lam. 20)

1 Polished plano-relief vase with hollow round supports. Geometric, symbolic designs (Ibid, Lam. 20)

1 Thin Orange ring base bowl with fire clouding. diam. $20 \mathrm{~cm}$, ht. $8 \mathrm{~cm}$ MNA 9-4340 2/3

$1 \quad$ Thin Orange ovate jar with flaring rim and painted red disks (Ibid, fig. 130)

1 Polished red on brown jar. diam. $25 \mathrm{~cm}$, ht. $27 \mathrm{~cm}$ (lbid,fig. 170)

1 Thin Orange ring base bowl with incised punctate decoration. diam. $20.3 \mathrm{~cm}$, ht. $9 \mathrm{~cm}$

2 Painted upright bowl in non-specular red. Diam. $9 \mathrm{~cm}$, ht. $2 \mathrm{~cm}$ MNA 9-4787 1/2

1 Polished Tlaloc jar. Ht. $20 \mathrm{~cm}$ MNA 9-2845

11 Fine Matte miniature wide mouth jars

12 Fine Matte miniature simple dish

$1 \quad$ Fine Matte miniature crude dish

$4 \quad$ Clay palettes

$6 \quad$ Orange beads

$4 \quad$ White beads

$1 \quad$ Beads or possible whorl

1 Shell needle

Metepec Tetitla Burial 11

1 Adult female

Provenience: East Platform, Northeast Temple group (fig. 25)

2 Polished cylindrical tripod vases with crude plano-relief decoration in abstract designs (Séjourné 1966a, Lam. 17,19)

4 Polished obtuse angle outcurving bowls

26 Fine Matte miniature ollitas

$1 \quad$ Clay slab 
Metepec Burial 13, Tetitla

1 Adult male

Provenience: Room bordering East wall (fig. 25)

1 Polished outcurving bowl with pattern polish interior. diam. $23.5 \mathrm{~cm}$, base $15 \mathrm{~cm}$, ht. $5.2 \mathrm{~cm}$ MNA 9-2980

1 Polished outcurving bowl. diam. $25 \mathrm{~cm}$, base $14 \mathrm{~cm}$, ht. $5 \mathrm{~cm}$ MNA 9-2980

1 Polished outcurving bowl. diam. $27.4 \mathrm{~cm}$, base $17 \mathrm{~cm}$, ht. $6 \mathrm{~cm}$ MNA $43631 / 17$

1 Fine Matte 3-handled cover with wide border

1 Fine Matte handleless cover with stamped design. diam. $25 \mathrm{~cm}$ (lbid, fig. 29 top, center)

$1 \quad$ Thin Orange ring base bowl

1 Polished outcurving bowl with pattern polish interior. Ht. $5.2 \mathrm{~cm}$, diam. at rim $23.5 \mathrm{~cm}$, at base $15 \mathrm{~cm}$

Metepec Burial 29, Tetitla

2 Adults, male and female

Provenience: Patio, Northwest unit (fig. 25)

1 Polished wide mouth jar with offset nubbins. Ht. $12 \mathrm{~cm}$, diam. $17 \mathrm{~cm}$

Shell fragments

\section{Metepec Tetitla Burial 30}

1 Adult female

Provenience: South center room, Northwest unit (fig. 25)

1 Thin Orange ring base bowl. Ht. $3.5 \mathrm{~cm}$, diam. at rim $12.5 \mathrm{~cm}$

1 Thin Orange effigy vessel, ball player. $\mathrm{Ht} .19 .5 \mathrm{~cm}$, diam. at rim $15 \mathrm{~cm}$ (Ibid, Lam. 43, 44, 52)

1 Polished obtuse angle outcurving bowl with pattern polished interior. $\mathrm{Ht} .3 .5 \mathrm{~cm}$, diam. $21 \mathrm{~cm}$ MNA 9-2947

1 Low Polished outcurving bowl. Ht. $3.5 \mathrm{~cm}$, diam. at rim $22 \mathrm{~cm}$, at base $13 \mathrm{~cm}$ MNA 9-2922

3 Polished outcurving bowls with obtuse angle bases and pattern polish interiors. Ht. 4 to $5.5 \mathrm{~cm}$, diam. at rim $23,26 \mathrm{~cm}$ MNA $9-4307 / 23$

5 Polished outcurving bowls with obtuse angle bases. Ht. $2.5 \mathrm{~cm}$, diam., approx. $13 \mathrm{~cm}$ 
1 Polished cylindrical vase with zone polished design basal molding and bud-like supports. Ht. $12.5 \mathrm{~cm}, 15.5 \mathrm{~cm}$ (Séjourné 1966a, fig. 69 bottom) MNA 9-2723

1 Matte cover-plate with raised border. Red pigment inside. $\mathrm{Ht} .6 \mathrm{~cm}$, diam. $16 \mathrm{~cm}$ MNA 9-2923

1 Polished wide mouth jar with flush nubbins. Ht. $13 \mathrm{~cm}$, diam. at rim $14 \mathrm{~cm}$

4 Matte obtuse angle bowls. Ht. $2.7 \mathrm{~cm}$ to $3.2 \mathrm{~cm}$, diam. at rim 12.3 to $12.7 \mathrm{~cm}$ MNA 9-4360

2 Matte plates. Ht. $2 \mathrm{~cm}$, diam. at rim $14 \mathrm{~cm} \mathrm{MNA} \mathrm{9-2918}$

2 Matte miniature ollitas

1 Matte plate. Ht. $2.5 \mathrm{~cm}$, diam. at rim $13 \mathrm{~cm}$ MNA 9-2477

1 Matte molded censer adorno with geometric design

Metepec Burial 33, Tetitla

1 Adult

Provenience: Northwest corner, Northeast Annex (fig. 25)

1 Thin Orange and silver mica ring base bowl (worn and mended by crack-lacing).

Diam. at rim $25 \mathrm{~cm}$, ht. $9.6 \mathrm{~cm}$ MNA 9-4340 3/3

1 Thin Orange ring base bowl. diam. at rim $16 \mathrm{~cm}$, ht. $5 \mathrm{~cm}$ MNA 9-2951

1 Thin Orange ring base bowl with crack-lacing. diam. $25 \mathrm{~cm}$, kt. $9 \mathrm{~cm}$

1 Burnished red-rimmed olla with roll rim. Maximum diam. $38 \mathrm{~cm}$ Ht. $34.5 \mathrm{~cm}$

1 Polished outcurving bowl with pattern polish interior. Diam. $24.4 \mathrm{~cm}$, ht. $5.5 \mathrm{~cm}$ MNA 9-2950

1 Coarse Matte 3-prong burner with unperforated walls. Diam. $22 \mathrm{~cm}$, ht. $12 \mathrm{~cm}$

1 Pattern polish upright bowl. diam. $23 \mathrm{~cm}$, ht. $8 \mathrm{~cm}$

1 Coarse Matte Incensario base with typical Metepec style rim flange. diam. $21.7 \mathrm{~cm}$, diam. at base $13 \mathrm{~cm}$, ht. $8 \mathrm{~cm}$ MNA 9-4435

1 Coarse Matte Incensario base with small flange. diam. $26.6 \mathrm{~cm}$, base $14 \mathrm{~cm}$, ht. $10 \mathrm{~cm}$ MNA 9-2942

1 Coarse Matte Incensario base with moderate overhang flange and white paint.

Diam. $15.5 \mathrm{~cm}$, at base $11.5 \mathrm{~cm}$, ht. $12 \mathrm{~cm}$ MNA 9-2921

1 Fine Matte handleless cover-plate with wide border

1 Fine Matte dish, warped. diam. $14.5 \mathrm{~cm}$, ht. $3 \mathrm{~cm}$ MNA 9-2956 
Metepec Tetitla Offering 16

Provenience: Extreme southeast room of compound (fig. 25)

1 Coarse Matte conical incensario lid with elaborate moldmade adornos mounted on chimney cone and elaborate feathered backdrop. Ht. $21 \mathrm{~cm}$, diam. at base $19 \mathrm{~cm}$ MNA Teotihuacan Room (Ibid, fig. 214)

Metepec Tetitla Offering 18

Provenience: North room, group near center of compound (fig. 25)

1 Polished (streakily) outcurving bowl with matte exterior, slightly concave base and rounded side-base angles. Ht. $5 \mathrm{~cm}$, diam. at rim $22 \mathrm{~cm}$ MNA 9-4360

1 Polished obtuse angle outcurving bowl with "pattern polish" interior. $\mathrm{Ht} .5 \mathrm{~cm}$, diam. at rim $24 \mathrm{~cm}$ MNA 9-4363 16/19

1 Streak Polished outcurving bowl, well constructed. Ht. $3.2 \mathrm{~cm}$, diam. $24 \mathrm{~cm}$, base $10.5 \mathrm{~cm}$ MNA 9-2981

1 Low Polished outcurving bowl. Ht. $2 \mathrm{~cm}$, diam. at rim $14 \mathrm{~cm} \mathrm{MNA} \mathrm{9-4328} \mathrm{6/8}$

1 Copa ware cylindrical vase with double basal molding and moldmade heads set in flange. Ht. $13.8 \mathrm{~cm}$, diam. at rim $13.2 \mathrm{~cm}$, at base $10.5 \mathrm{~cm}$ MNA 9-2974

\section{Metepec Tetitla Offering 22}

Provenience: Patio with columns, central patio group (fig. 25)

1 Coarse Matte incensario 2-part base decorated with pastillaje necklace, painted yellow, pale green and red. Ht. $17 \mathrm{~cm}$, diam. at rim $23 \mathrm{~cm}$ (Séjourné 1966a: Lam. 60 left, fig. 13) MNA.

1 Copa ware cylindrical vase with molded slab supports and molding with "fat god" adornos. Ht. $14 \mathrm{~cm}$, diam. at rim $13.5 \mathrm{~cm}$ (Séjourné 1966a: Lam. 60 right)

Metepec Tetitla Offering 38

Provenience:Portico of west central patio group (fig. 25)

1 Stucco Painted cylindrical vase decorated with high relief molded figures depicting males in rich attire. Ht. $13 \mathrm{~cm}$, diam. at rim $15 \mathrm{~cm}$ (Ibid, fig. 91). MNA, Teotihuacan Room

Metepec Tetitla Offering 39

Provenience: South room, west-central patio group (fig. 25) 
1 Coarse matte 3-prong burner with cutout rim and molded heads on prongs. $\mathrm{Ht} .11 \mathrm{~cm}$, diam. at rim $32.5 \mathrm{~cm}$, prong length $7 \mathrm{~cm}$, diam. $5 \mathrm{~cm}$ MNA 9-2552 (Ibid, fig. 216)

1 Fine Matte 3-handled cover-plate. Ht. $6 \mathrm{~cm}$, diam. at rim $25 \mathrm{~cm}$ MNA 9-3007

1 Dense ware incurved corrugated bowl. Ht. $4.8 \mathrm{~cm}$, diam. at rim $10 \mathrm{~cm}$, at base $4.5 \mathrm{~cm}$ MNA 9-2644

1 Coarse Matte flanged incensario base with conical lid decorated with gouged indentations. Ht. $39 \mathrm{~cm}$, diam. at rim $30 \mathrm{~cm}$

1 Fine Matte cover-plate with nicked rim. $\mathrm{Ht} .3 \mathrm{~cm}$, diam. at rim $16.5 \mathrm{~cm}$

\section{Metepec Tetitla Offering 40}

Provenience: Northwest room of southwest patio group (fig. 25)

1 Polished flaring vase, crudely finished, with nubbin supports, slightly offset. $\mathrm{Ht} .8 \mathrm{~cm}$, diam. at rim $10 \mathrm{~cm}$ MNA 9-4879

1 Fine Matte 3-handled cover-plate. $\mathrm{Ht} .7 \mathrm{~cm}$, diam. at rim $24.5 \mathrm{~cm}$

40 Fine Matte miniature everted rim vases with offset nubbins. Ht. $7.5 \mathrm{~cm}$ to $9 \mathrm{~cm}$ diam. at rim 10 to $13 \mathrm{~cm}$

15 Fine Matte miniature jars. Ht. 5 to $7 \mathrm{~cm}$, diam. 5 to $8 \mathrm{~cm}$ MNA 9-4309

31 Fine Matte miniature outcurving bowls. $\mathrm{Ht} .3 \mathrm{~cm}$, diam. at rim 10 to $12 \mathrm{~cm}$ MNA 9-4302, 9-2916, 9-4328 7/8

Metepec Tetitla Offering 45

Provenience: West central patio group (fig. 25)

1 San Martin Orange crater. Ht. $20 \mathrm{~cm}$, diam. $30 \mathrm{~cm}$ MNA 9-2613

1 Painted pale red on natural flared basin with symbolic designs and large round hollow supports. Ht. $17 \mathrm{~cm}$, diam. at rim $35.2 \mathrm{~cm}$, at base $25 \mathrm{~cm}$ MNA 9-2641 (Ibid, fig. 164, bottom)

1 Coarse Matte incensario lid, biconical, gouge incised and painted in chalky white. Ht. $63 \mathrm{~cm}$, diam. $31 \mathrm{~cm}$

Metepec Tetitla Offering 50

Provenience: North portico,northwest patio group (fig. 25)

1 Painted specular red on natural basin with large hollow supports. Ht. $24 \mathrm{~cm}$ diam. at rim $46 \mathrm{~cm}$ MNA 9-2623 
Metepec Tetitla Offering 65

Provenience: Northwest corner, north central part of compound (fig. 25)

1 San Martin Orange scraped basin with fugitive red design repeated four times around vessel. $\mathrm{Ht} .14 \mathrm{~cm}$, diam. $46 \mathrm{~cm}$ at rim, $32 \mathrm{~cm}$ at base. MNA 9-3242

1 Thin Orange bowl with incised and point punctate decoration in S motif. $\mathrm{Ht} .7 .4 \mathrm{~cm}$, diam. at rim $20.4 \mathrm{~cm}$ MNA 9-2907

1 El Tajín Lustrous Orange plano-relief vase with resist decoration. Supports missing. Ht. $15 \mathrm{~cm}$, diam. $25 \mathrm{~cm}$

1 Polished outcurving bowl. Ht. $7 \mathrm{~cm}$, diam. $23.8 \mathrm{~cm}$ MNA 9-2958

1 Polished outcurving obtuse angle bowl. $\mathrm{Ht} .2 \mathrm{~cm}$, diam. $20 \mathrm{~cm}$

1 Polished (poorly) outcurving bowl. Ht. $4.5 \mathrm{~cm}$, diam. at rim $24 \mathrm{~cm}$ MNA 9-4363 8/19

Metepec Tetitla Offering 66

Provenience: Patio, Northwest patio group (fig. 25)

1 Zone Polished upright bowl. Ht. $6.5 \mathrm{~cm}$, diam. at rim $20.5 \mathrm{~cm}$, at base $12 \mathrm{~cm}$ MNA 9-2780

1 Fine Matte cover-plate with 3 loop handles. Ht. $5.4 \mathrm{~cm}$, diam. at rim $25.8 \mathrm{~cm}$ MNA 9-2925

1 Polished outcurving bowl

Metepec Tetitla Offering 70

Provenience: Northeast patio group (fig. 25)

1 Polished outcurving bowl, streaky finish. Ht. $5.7 \mathrm{~cm}$, diam. at rim $27.8 \mathrm{~cm}$, at base $16.5 \mathrm{~cm}$ MNA 9-4363 2/19

1 Polished outcurving bowl, streaky finish. $\mathrm{Ht} .6 .3 \mathrm{~cm}$, diam. at rim $27.5 \mathrm{~cm}$, at base $17.4 \mathrm{~cm}$ MNA 9-4363 6/19

\section{Metepec Tetitla Offering 71}

Provenience: Outside north wall (fig. 25)

1 Polished outcurving bowl with "pattern polish" interior and matte exterior. $\mathrm{Ht} .5 .5 \mathrm{~cm}$, diam. $22 \mathrm{~cm}$ MNA 9-4363 9/19 
Unphased Tetitla Burial 1

Age-sex unknown

Provenience: West Platform, Northeast Temple group (fig. 25)

No data on offerings

Unphased Tetitla Burial 21

Unknown

Provenience: Northwest patio group (fig. 25)

No data

Unphased Tetitla Burial 22

Adult male

Provenience: Central room with columns (fig. 25)

Unphased Tetitla Burial 23

Unknown

Provenience: North central patio group, east room (fig. 25)

No data

Unphased Tetitla Burial 24

1 Adult, 1 Child

Provenience: Northwest Patio, east room (fig. 25)

No data

Unphased Tetitla Burial 25

Adult female

Provenience: East portico room,North central room group (fig. 25)

No data

Unphased Tetitla Offering 11

Provenience: Level 2, north central patio (fig. 26)

1 Gulf Coast Fine Paste negative painted brown on natural vase with cutout rectangular supports. Ht. $22 \mathrm{~cm}$, diam. at rim $28 \mathrm{~cm}$ (Ibid, fig. 88) 
Unphased Tetitla Offering 36

Provenience: North room of central patio (fig. 25)

1 Polished specular red on brown basin with hollow support scars. Design is serpent head with feathers. Ht. $19 \mathrm{~cm}$, diam. $46 \mathrm{~cm}$

27 Fine Matte miniature jars. Ht. $3.5 \mathrm{~cm}$ to $4 \mathrm{~cm}$, diam. 3.2 to $4.5 \mathrm{~cm}$

17 Fine Matte miniature plates. Ht. $.8 \mathrm{~cm}$ to $1.6 \mathrm{~cm}$, diam. 5.6 to $6.9 \mathrm{~cm}$

Unphased Tetitla Offering 48

Provenience: Exact location unknown

1 Gulf Coast Stuccoed White Laminated paste bowl. Ht. $8 \mathrm{~cm}$, diam. approx. $15 \mathrm{~cm}$ MNA 9-2813 (Ibid, fig. 203)

Unphased Tetitla Offering 60

Provenience: North room of large north patio (fig.25; Ibid fig. 220)

1 Stuccoed and Painted Thin Orange jar with nubbin supports

\section{BURIALS AND CACHES FROM TETITLA COMPOUND}

(Moore 1966)

Early Xolalpan Tetitla, Hearth Cache1

Provenience: Tetitla Room 4J, Excavation 2 (Moore 1966, fig. 4)

2 Copa ware vases with hollow round supports (Ibid, Plate III 2, 3)

1 Coarse Matte incensario: censer base, adornos

6 Fine Matte handled cover-plates (Ibid: Plate III, 8, 9)

1 Thin Orange bowl. Diam. at $\operatorname{rim} 26 \mathrm{~cm}$, ht $7.5 \mathrm{~cm}$

2 Polished widemouth jars (Ibid: Plate IV: 4, 5)

1 Polished Tlaloc jar with small body and wide flaring neck (Ibid: Plate III,1)

Fine Matte miniature ollitas and plates

16 Green obsidian prismatic blades 
16 Green obsidian projectile points

1 Green obsidian miniature point

12 Green obsidian prismatic blades and 11 fragments (Ibid: Plate III: 17, 18)

11 Large fan-shaped shells

3 Large corrugated fan-shaped shells

6 Oval, 8 spiral, 2 clam shells

1 Shell necklace: 35 beads

$5 \quad$ Green stone beads ( 3 possible jade)

1 Bone needle

12 Painted slate pieces with red motifs

$1 \quad$ Clay disk, unfired with red paint

Yellow ochre

Bird bones

Early Xolalpan Tetitla, Cache 2 (Looted)

Provenience: Building 3, Room 3-G (Ibid: fig. 3)

1 Polished brown outcurving bowl (Ibid: fig. 6)

1 Thin Orange outcurving bowl with corrugated body and nubbin supports (Ibid: fig. 6)

$7 \quad$ Fine Matte miniatures

$1 \quad$ Polished brown vase lid

$1 \quad$ Fresco painted gourd

Late Xolalpan Tetitla, Burial 1

1 Adult, middle-aged

Provenience: West of Armillas' excavation, south room (fig. 26; Moore 1966, fig. 3)

$1 \quad$ Polished cylindrical vase

2 Thin Orange bowls

2 Copa ware vase with round hollow supports (Ibid: Plate I: 2, 3) 
$1 \quad$ Polished Tlaloc jar (Ibid: Plate I:1)

$34 \quad$ Fine Matte miniature plates

36 Fine Matte miniature ollitas (Ibid: Plate II: 13,14)

7 Polished outcurving bowls (Ibid: Plate I: 18,19; Plate II 12, 20, 21, 22 )

6 Polished low-walled plates (Ibid: Plate II: 11, 15, 17)

$2 \quad$ Polished floreros

1 Fine Matte adorno

2 Obsidian prismatic blades, 5 broken blades

3 Jade beads

3 Figurine heads (1 moldmade)

Burnt shell

Blue organic material

Cloth or matting

Charcoal

Unphased Tetitla, Cache 3 (looted)

Provenience: Building 3 Patio, Room 3H (Ibid: fig. 3)

Fine matte miniature ollitas and plates

Polished outcurving bowl, no supports 


\section{BURIALS AND OFFERINGS FROM ZACUALA PALACE AND PATIOS}

\section{Late Tlamimilolpa-Early Xolalpan Zacuala Burial 6}

1 Adult male, 1 unknown.

Provenience: Zacuala Patios (fig. 27; Séjourné 1959: fig. 35).

1 Polished brown outcurving bowl with well formed nubbins and design in fugitive with paint. Diam. at rim $13 \mathrm{~cm}$, ht. $4.7 \mathrm{~cm}$ MNA 9-4327 6/10.

1 Polished tan wide mouth jar with conical nubbin supports. Diam. at rim $13 \mathrm{~cm}$, at base $6 \mathrm{~cm}$, ht. reconstructed $13 \mathrm{~cm}$ MNA 9-4335 9/9.

1 Polished outcurving bowl with obtuse angle base, vestigial nubbins. Diam. at rim $12.5 \mathrm{~cm}$, at base $6 \mathrm{~cm}$, ht. $4.2 \mathrm{~cm}$

$2 \quad$ Polished small upright bowls.

Late Tlamimilolpa-Early Xolalpan Zacuala Burial 10

Age-Sex unknown.

Provenience: Zacuala Patios (fig. 27; Séjourné 1959: fig. 35).

1 Polished black small vase with conical nubbins. Diam. at $\operatorname{rim} 5.2 \mathrm{~cm}$, at base $5.3 \mathrm{~cm}$, ht. $3.2 \mathrm{~cm}$ MNA 9-4489.

1 Polished outcurving bowl with tiny nubbins. Diam. at rim $10 \mathrm{~cm}$, at base $6 \mathrm{~cm}, \mathrm{ht} .4 \mathrm{~cm}$ MNA 9-4301 /10.

1 Polished black wide mouth jar with nubbins. Diam. at rim $13.7 \mathrm{~cm}$, at base, $8 \mathrm{~cm}$, ht. $12.5 \mathrm{~cm}$ MNA 9-4335 3/9.

1 Polished obtuse angle outcurving bowl with pattern polish on interior bottom.

Diam. at rim $14 \mathrm{~cm}$, at base $11 \mathrm{~cm}$, ht. $5 \mathrm{~cm}$ MNA 9-4359.

1 Matte outcurving bowl. Diam. at rim $13 \mathrm{~cm}$, at base $10.5 \mathrm{~cm}$, ht. $2.5 \mathrm{~cm}$ MNA 9-4349 1/3.

1 Matte composite incensario base and lid with molded adornos (Séjourné 1959: fig. 47).

Animal bones

\section{Early Xolalpan Zacuala Burial 5}

5 Individuals: 1 adult female, 1 adolescent, others unknown.

Provenience: Zacuala Patios (fig. 27; Séjourné 1959: fig. 35).

2 Painted specular red upright bowls: (1) Diam. at rim $11.4 \mathrm{~cm}$, base $7.5 \mathrm{~cm}$, ht. $2.9 \mathrm{~cm}$ MNA 9-2989; (2) Diam. at rim $11.4 \mathrm{~cm}$, at base $8 \mathrm{~cm}$, ht. $2.9 \mathrm{~cm}$ 
1 Polished tan cylindrical vase with conical nubbin supports. Diam. at rim, $7.5 \mathrm{~cm}$, at base $7.2 \mathrm{~cm}$, ht. $1.5 \mathrm{~cm}$ MNA 9-2714.

1 Polished outcurving bowl with vestigial nubbins. Diam. at $\operatorname{rim} 16 \mathrm{~cm}$, at base $9 \mathrm{~cm}$, ht. $4.5 \mathrm{~cm}$ MNA 9-4327 5/10.

1 Polished outcurving bowl with rounded base-side angles, no supports. Diam. at rim $12 \mathrm{~cm}$, ht. $3.2 \mathrm{~cm}$ MNA 4327 2/10.

1 Polished outcurving bowl with rounded base-side angle, no supports. Diam. at rim $12.8 \mathrm{~cm}$, ht. $3.2 \mathrm{~cm}$

1 Matte small jar. Diam. at rim $6.5 \mathrm{~cm}$, at base $4.5 \mathrm{~cm}$, ht. $5.5 \mathrm{~cm}$ MNA 9-2603.

1 Matte miniature ollita. MNA 9-4301.

Early Xolalpan Zacuala Burial 11

1 Adult Female.

Provenience: Zacuala Patios (fig. 27; Séjourné 1959: figs. 31, 35).

1 Polished upright bowl with fine groove incising. Diam. at $\operatorname{rim} 21 \mathrm{~cm}$, at base $13 \mathrm{~cm}$, ht. $7 \mathrm{~cm}$ MNA 9-2952.

1 Polished wide mouth jar with nubbin supports (burnt). Diam. at rim $12.7 \mathrm{~cm}$, at base $8 \mathrm{~cm}$, ht. $11.3 \mathrm{~cm}$ MNA 9-2599.

1 Polished recurved bowl. Diam. at $\operatorname{rim} 13 \mathrm{~cm}$, at base $11 \mathrm{~cm}$, ht. $4.5 \mathrm{~cm}$ MNA 9-4359 13/15.

2 Low Polish outcurving bowls with obtuse angle bases (Séjourné 1959: lam. 31).

$1 \quad$ Molded head puppet figurine (Séjourné 1959: lam. 32).

$8 \quad$ Matte miniature ollitas.

$1 \quad$ Matte miniature plate.

$8 \quad$ Matte miniature bowls

1 Streak Polished miniature bowl. MNA 9-4306.

1 Obsidian blade.

1 shell bead.

Slate fragments with red motifs. 


\section{Early Xolalpan Zacuala Burial 27}

1 Adult female.

Provenience: Zacuala Palace, below stairs, main entrance stairway (fig. 28; Séjourné 1959: lam. 36).

1 Tlaloc jar (Séjourné 1959: lam. 36).

1 Polished fluted short neck jar with traces of stucco. $\mathrm{Ht} .12 \mathrm{~cm}$, diam. at rim $9 \mathrm{~cm}$ MNA 9-2806.

2 Polished short neck jars (Séjourné 1959: lam. 36).

$1 \quad$ Polished vase with rounded basal flange and hollow round flat bottom supports. Ht. $10 \mathrm{~cm}$, diam. at rim $13 \mathrm{~cm}$ MNA 9-2733.

1 Polished vase, bicurvate with slit disk nubbins around flange and hollow round bottom supports. Ht. $9.5 \mathrm{~cm}$, diam. at rim $14 \mathrm{~cm}$ MNA 9-2893.

1 Polished vase with flat disks around basal border and hollow round bottom supports. Ht. $12.4 \mathrm{~cm}$, diam. at rim $13.8 \mathrm{~cm}$ MNA 9-2888.

1 Polished outcurving bowl, flat bottom. Ht. $5.5 \mathrm{~cm}$, diam. at rim $15 \mathrm{~cm} \mathrm{MNA9-4300.}$

1 Polished outcurving bowl with vestigial nubbins. Ht. $5.5 . \mathrm{cm}$, diam. at rim $14 \mathrm{~cm}$ MNA 9-4300.

1 Polished outcurving bowl. Ht. $4.7 \mathrm{~cm}$, diam. at rim $15.8 \mathrm{~cm}$ MNA 9-4327.

1 Polished outcurving bowl. Ht. $4.3 \mathrm{~cm}$, diam. at rim $15 \mathrm{~cm}$ MNA 9-4327.

3 Low polished outcurving bowls, medium size. MNA 9-4306.

$7 \quad$ Matte miniature ollitas.

$4 \quad$ Matte miniature plates.

1 Thin Orange ringbase bowls. Ht. $6.7 \mathrm{~cm}$, diam. at rim $21 \mathrm{~cm}$ MNA 9-4339 2/6.

2 Thin Orange ringbase bowls. Ht. $6.2 \mathrm{~cm}$, diam. at rim $19 \mathrm{~cm}$ MNA 9-4339 2/6.

1 Plano-Relief decorated vase. Diam. at rim $13.5 \mathrm{~cm}$, ht. $12 \mathrm{~cm}$ MNA 9-2873.

$1 \quad$ Perforated pyrite disk.

1 shell pendant (pectoral) incrusted with jade in 3 concentric circles.

2 earrings, honey colored, made of resin.

1 pyrite disk with blue mosaic.

$5 \quad$ gray obsidian blades. 
green obsidian blade.

pieces of mica.

pieces of painted slate.

Early Xolalpan Zacuala Burial 30

1 Adult female

Provenience: Zacuala Palace main temple (fig. 28).

1 Polished outcurving bowl with vestigial nubbins. Diam. at rim $20 \mathrm{~cm}$, ht. $8.8 \mathrm{~cm}$ MNA 9-3024.

1 Polished outcurving bowl with incising. Diam. $11.5 \mathrm{~cm}$, ht. $3.5 \mathrm{~cm}$ MNA 9-3027.

1 Copa Ware vase with pattern polish design and round hollow supports. Diam. at rim 13 $\mathrm{cm}$, at base $10.7 \mathrm{~cm}$, ht. $10.5 \mathrm{~cm}$ MNA 9-2967.

4 Polished outcurving bowls: 1) Diam. at rim $22.8 \mathrm{~cm}$, at base $15 \mathrm{~cm}$, ht. $7.5 \mathrm{~cm}$ MNA 9-4342 3/5; (2) Diam. at rim $21.5 \mathrm{~cm}$, at base $14.4 \mathrm{~cm}$, ht. $6 \mathrm{~cm}$ MNA 9-4342 1/5; (3) Diam. at rim $24 \mathrm{~cm}$, at base $16.5 \mathrm{~cm}$, ht. $8.1 \mathrm{~cm}$ MNA 9-4342 4/5; (4) Diam. at rim $25 \mathrm{~cm}$, at base $16.5 \mathrm{~cm}$, ht. $7 \mathrm{~cm}$ MNA 9-4342 2/5.

Early Xolalpan Zacuala Burial 31

Multiple burial: 3 adult males, 1 adult female, two children.

Provenience: Zacuala Palace main temple (fig. 28).

$1 \quad$ Figurine.

Various shells.

Early Xolalpan Zacuala Offering 2

1 Adult Female.

Provenience: "Cámara Roja" The Red Room, Zacuala Patios (fig. 27)

1 Painted recurved specular red bowl. Diam. at rim $9.9 \mathrm{~cm}$, at base $7 \mathrm{~cm}$, ht. $3.5 \mathrm{~cm}$ MNA 9-2717.

$7 \quad$ Matte miniature plates.

1 Matte miniature ollita.

$1 \quad$ Matte miniature florero. 
2 Matte incensario bases with wide flanges .

\section{Late Xolalpan Zacuala Burial 1}

\section{Age-sex unknown}

Provenience: Zacuala Patios (fig. 27).

1 Polished tan upright bowl. Diam. at rim $18 \mathrm{~cm}$, at base $10 \mathrm{~cm}$, ht. $5.8 \mathrm{~cm}$ MNA 9-4359.

1 Polished outcurving bowl with rounded base angle and pattern polish interior. Diam. at rim $14.5 \mathrm{~cm}$, at base $8 \mathrm{~cm}$, ht. $2.5 \mathrm{~cm}$ MNA 9-4359.

1 Polished outcurving bowl with rounded base angle, pattern polish on interior. Diam. at $\operatorname{rim} 13 \mathrm{~cm}$, at base $8 \mathrm{~cm}$, ht. $2.4 \mathrm{~cm}$ MNA 9-4359.

1 Plano-relief cylindrical tripod vase with butterfly motif (Séjourné 1959: lams. 38, 41).

1 Plano-relief cylindrical vase with geometric design, vase with hollow round supports (ibid., lam. 38).

1 Copa ware vase with round hollow supports. Diam. at $\operatorname{rim} 11.8 \mathrm{~cm}$, at base $11 \mathrm{~cm}$, ht. $11 \mathrm{~cm}$ MNA 9-4320 4/8.

1 Copa ware vase with round hollow supports. Diam. at rim $12.5 \mathrm{~cm}$, at base $11.5 \mathrm{~cm}$, ht. $12.7 \mathrm{~cm}$ MNA 9-4320 5/8.

1 Thin Orange bowl, incised. Diam. at rim $12.5 \mathrm{~cm}$, diam. ring base $4.5 \mathrm{~cm}$, ht. $6.4 \mathrm{~cm}$ MNA 9-2910.

1 Thin Orange bowl, incised round punctate. Diam. at rim $13.4 \mathrm{~cm}$, diam. ring base $5 \mathrm{~cm}$, ht. $6.4 \mathrm{~cm}$ MNA 9-2999.

1 Florero with tall flaring rim. Diam. at rim $10.3 \mathrm{~cm}$, at base $7 \mathrm{~cm}$, ht. $16.1 \mathrm{~cm}$ MNA 9-2957.

1 Coarse Matte incensario base in 3 parts with wide curved rim flanges (Séjourné 1959: lam. 38).

6 Molded censer adornos (stars, feathers) (ibid.,lam.38)

1 Censer plaque.

$1 \quad$ Matte miniature florero.

6 Matte miniature ollitas.

5-6 Matte miniature plates.

$1 \quad$ Polished small cylindrical tripod with lid. 
2 Tortoise shells.

1 Obsidian blade.

Late Xolalpan Zacuala Burial 2

Age-sex unknown.

Provenience: Zacuala Patios (fig. 27).

1 Plano-relief vase with round hollow supports and representation of Xipe (Séjourné 1959: fig. 40 right).

1 Plano-relief vase with hollow cylindrical supports and symbolic motifs (ibid.,1959: fig. 40 left).

1 Stucco Painted bowl. Possible heirloom. MNA 9-2804.

1 Copa ware vase with diagonally incised band and molded supports. Diam. at rim $12.5 \mathrm{~cm}$, ht. $8.2 \mathrm{~cm}$ MNA 9-2894.

1 Polished outcurving bowl with rounded base angle and incised interior rim. Diam. at rim $13 \mathrm{~cm}$, at base $10 \mathrm{~cm}$, ht. $8.2 \mathrm{~cm}$ MNA 9-4359.

$1 \quad$ Polished incised upright bowl.

2 Matte miniature ollitas.

$4 \quad$ Matte miniature plates.

1 Matte cover-plate (without handles). Diam. at rim $26.5 \mathrm{~cm}$, ht. $5.5 \mathrm{~cm}$ MNA 9-2621.

Late Xolalpan Zacuala Burial 4

1 Adult male, 1 adult female.

Provenience: Zacuala Patios (fig. 27).

1 Polished vase with hollow round supports. Diam. at rim $10.7 \mathrm{~cm}$, at base $9.2 \mathrm{~cm}$, ht. $7.5 \mathrm{~cm}$ MNA 9-2973.

$1 \quad$ Polished upright bowl.

2 Polished outcurving bowls.

$5 \quad$ Matte miniature plates.

2 Matte miniature ollitas. 


\section{Late Xolalpan Zacuala Burial 7}

Age-sex unknown.

Provenience: Zacuala Patios (fig. 27).

1 Monte Albán style low black vase with vertical sides and slightly rounded side-base angle. The design is a scale and line motif in a band format. (See CBA 271d, 274b) (Séjourné 1959: lam. 40). MNA 9-2721

1 Polished brown outflaring bowl with line polish design in base. Diam. at rim $20.5 \mathrm{~cm}$, at base $13 \mathrm{~cm}$, ht. $4.5 \mathrm{~cm}$ MNA 9-4301.

Late Xolalpan Zacuala Burial 9

1 Adult Male.

Provenience: Zacuala Patios (fig. 27).

$4 \quad$ Low Polish small outcurving bowls.

1 Low Polish outcurving bowl with rounded base, no supports, matte exterior. Diam. at rim $12.8 \mathrm{~cm}$, ht. $3.2 \mathrm{~cm}$ MNA 9-4327 2/10.

Late Xolalpan Zacuala Burial 15

1 Adult Female.

Provenience: Zacuala Patios (fig. 27).

1 Low Polish outcurving bowl. Diam. at rim $11.9 \mathrm{~cm}$, at base $10.5 \mathrm{~cm}$, ht. $2.5 \mathrm{~cm}$ MNA 9-4349 3/3.

1 Streak Polished obtuse angle bowl. Diam. at rim $11.5 \mathrm{~cm}$, ht. $2.5 \mathrm{~cm} \mathrm{MNA} \mathrm{9-4306} \mathrm{/29.}$

1 Low Polish orange outcurving bowl with rounded base angle. Bears traces of red pigment. Diam. at rim $11.5 \mathrm{~cm}$, ht. $2.5 \mathrm{~cm}$ MNA 9-4306/31.

1 Streak Polished outcurving bowl (burnt). Diam. at rim $15.5 . \mathrm{cm}$, ht. $3.5 \mathrm{~cm}$ MNA 9-4301 /12.

1 Streak Polished outcurving bowl with traces of red pigment (burnt). Diam. at rim $17.5 \mathrm{~cm}$, ht. $4 \mathrm{~cm}$ MNA 9-4301/13.

1 Streak Polished outcurving bowl (burnt). Diam. at rim $14 \mathrm{~cm}$, ht. $2.5 \mathrm{~cm}$ MNA 9-4306 /3.

1 Pattern Polished outcurving bowl with rounded base angle MNA 9-4301/14.

1 Matte 3-handled cover (Séjourné 1959, lam. 33, left).

$4 \quad$ Low Polished small wide mouth jars. 
$2 \quad$ Polished upright bowls.

$1 \quad$ Matte miniature florero.

$1 \quad$ Matte miniature 3-handled cover.

Late Xolalpan Zacuala Burial 16.

Age-sex unknown.

Provenience: Zacuala Patios (fig. 27).

1 Polished outcurving bowl (Late Tlamimilolpa style) with vestigial nubbins and incised cloud motif. Diam. at rim $22 \mathrm{~cm}$, at base $15.5 \mathrm{~cm}$, ht. $6 \mathrm{~cm}$ MNA 9-3025.

1 Polished wide mouth jar (crudely made, burnt). Diam. at rim $14.4 \mathrm{~cm}$, at base $10 \mathrm{~cm}$, ht. $14 \mathrm{~cm}$ MNA 9-4339 2/9.

1 Low Polish flaring bowl (crude). Diam. at rim $13.1 \mathrm{~cm}$, at base $10.5 \mathrm{~cm}$, ht. $2.7 \mathrm{~cm}$ MNA 9-4344 2/3.

$2 \quad$ Matte dishes.

$2 \quad$ Stone "polishers".

1 Polish broken outcurving bowl (base only).

1 Stone plumb bob.

Late Xolalpan Zacuala Burial 24.

1 Individual.

Provenience: Zacuala Patios (fig. 27).

1 Polished thick-walled cylindrical vase with simple wide groove incising and round supports. Diam. at rim $13 \mathrm{~cm}$, at base $11 \mathrm{~cm}$, ht. $10.5 \mathrm{~cm}$ MNA 9-4328.

1 Copa ware vase with short round supports. Diam. at $\operatorname{rim} 11.2 \mathrm{~cm}$, at base $10.2 \mathrm{~cm}$, ht. $10.4 \mathrm{~cm}$ MNA 9-4320.

1 Polished wide mouth jar with pattern polish, flare rim, nubbin supports (well made). Diam. at rim $10 \mathrm{~cm}$, at base $8 \mathrm{~cm}$, ht. $10.8 \mathrm{~cm}$ MNA 9-4335 1/9.

1 Polished wide mouth jar with pattern polish, no supports. Diam. $9.5 \mathrm{~cm}$, at base $7 \mathrm{~cm}$, ht. $9.5 \mathrm{~cm}$ MNA 9-4335 4/9.

1 Polished finely incised recurved bowl. Diam. at rim $15 \mathrm{~cm}$, at base $9 \mathrm{~cm}$, ht. $5.2 \mathrm{~cm}$ MNA 9-9359 2/15.

1 Polished finely incised recurved bowl. Diam. at rim $14 \mathrm{~cm}$, at base $14 \mathrm{~cm}$, ht. $7 \mathrm{~cm}$ MNA 9-4371. 
1 Matte globular jar (burnt). Diam. at rim $8 \mathrm{~cm}$, at base $5 \mathrm{~cm}$, ht. $6.5 \mathrm{~cm} \mathrm{MNA} \mathrm{9-2937.}$

6 Matte miniature bowls; 3 outcurving bowls, 2 ollitas, 1 flaring bowl. MNA 9-4306 /16.

1 Puppet figurine (Séjourné 1959: fig. 44C) Radiocarbon determination (Sample Y1265): 1660 \pm 80 or $290 \pm$ A.D. $)$.

Late Xolalpan Zacuala Burial 28.

1 Adult male.

Provenience: Zacuala Palace (fig. 28).

1 Polished outcurving bowl. Diam. at rim $12.2 \mathrm{~cm}$, at base $8.4 \mathrm{~cm}$, ht. $2.2 \mathrm{~cm}$ MNA 9-2987.

1 Low Polished outcurving bowls, crude. Diam. $12.2 \mathrm{~cm}$, at base $8.4 \mathrm{~cm}$, ht. $2.2 \mathrm{~cm}$ MNA 9-2987.

2 Polished outcurving bowls, no supports.

$2 \quad$ Matte small bowls.

Late Xolalpan Zacuala Offering 1

No bones reported.

Provenience: Red Room (Cámara Roja) (fig. 27).

1 Polished recurved bowl. Diam. at rim $13.5 \mathrm{~cm}$, ht. $5 \mathrm{~cm}$ MNA 9-4359 8/15.

$1 \quad$ Polished outcurving bowl. MNA 9-4349.

1 Thin Orange ring base bowl. Diam. at rim $16.3 \mathrm{~cm}$, at base $6 \mathrm{~cm}$, ht. $6.8 \mathrm{~cm}$ MNA 9-4339 6/6.

Metepec Zacuala Burial 3

1 Adult Male.

Provenience: Zacuala Patios (fig. 27).

1 Polished outcurving bowl with rounded basal angle. Diam. at rim $13.5 \mathrm{~cm}$, at base $9 \mathrm{~cm}$, ht. $3.2 \mathrm{~cm}$ MNA 9-2986.

1 Polished black recurved bowl with slant cut rim. Diam. at rim $15.5 \mathrm{~cm}$, at base $9.5 \mathrm{~cm}$, ht. $5.8 \mathrm{~cm}$ MNA 9-4359.

1 Polished brown outcurving bowl with rounded base angle. Diam. at rim $15 \mathrm{~cm}$, at base $8.5 \mathrm{~cm}$, ht. $3.6 \mathrm{~cm}$ MNA 9-4359.

1 Polished wide mouth jar with pattern polish neck and nubbin supports. Diam. at rim $17 \mathrm{~cm}$, at base $10 \mathrm{~cm}$, ht. $19.4 \mathrm{~cm}$ MNA 9-4531. 
1 Polished wide mouth jar with nubbins. Diam. at rim $13.3 \mathrm{~cm}$, at base $6.3 \mathrm{~cm}$, ht. $10.2 \mathrm{~cm}$ MNA 9-2596.

1 Low Polished hemispherical bowl. Diam. at rim $12.5 \mathrm{~cm}$, ht. $2 \mathrm{~cm}$ MNA 9-2610.

1 Polished wide mouth jar with pattern polish neck. Diam. $16.5 \mathrm{~cm}$, at base $8.9 \mathrm{~cm}$, ht. $16.5 \mathrm{~cm}$ MNA 9-2602.

1 Thin Orange incised/punctate bowl.

2 Orange bowls (Thin Orange imitations).

$1 \quad$ Streak Polished outcurving bowl.

$4 \quad$ Matte miniature bowls.

$2 \quad$ Matte miniature plates.

Metepec Zacuala Burial 8

1 Adult.

Provenience: Zacuala Patios (fig. 27).

1 Polished black brown jar, globular with nubbins. Diam. at rim $9.6 \mathrm{~cm}$, at base $5.3 \mathrm{~cm}$, ht. $9.1 \mathrm{~cm}$ MNA 9-2976.

2 Polished upright bowls, semi-matte finish. MNA 9-4359.

1 Polished outcurving bowl with pattern polish interior and rounded basal angle. MNA 9-4301/7.

$4 \quad$ Matte small outcurving bowls.

$1 \quad$ Polished upright bowl.

Metepec Zacuala Burial 13

1 Adult male.

Provenience: Zacuala Patios (fig. 27).

1 Copa ware vase, crude. Diam. at rim $12.5 \mathrm{~cm}$, ht. $1 \mathrm{~cm}$ MNA 9-4320 2/8.

1 Thin Orange ring base bowl with incised comb punctate decoration. Diam. at rim $24 \mathrm{~cm}$, at base $8.5 \mathrm{~cm}$, ht. $8.2 \mathrm{~cm}$ MNA 9-2995.

1 Polished outcurving bowl with pattern polish design on interior. MNA 9-4301 /5.

6 Polished outcurving bowls, obtuse angle. MNA 9-4306 1/5 and 9-4301 1/2.

1 Quetzal bird seal (Séjourné 1959: Fig. 46). 
1 Hematite figurine.

Metepec Zacuala Burial 17

1 Adult Female.

Provenience: Zacuala Patios (fig. 27).

1 Thin Orange effigy vessel (possible canine) (Séjourné 1959: Fig. 45a).

1 Low Polish outcurving bowl. Diam. at rim $12.5 \mathrm{~cm}$, at base $6 \mathrm{~cm}$, ht. $2.8 \mathrm{~cm}$

Metepec Zacuala Burial 26.

1 Juvenile.

Provenience: Zacuala Patios (fig. 27).

1 Low Polished outcurving bowl (burnt). Diam. at rim $13.5 \mathrm{~cm}$, at base $8 \mathrm{~cm}$, ht. $3 \mathrm{~cm}$ MNA 9-9359.

$1 \quad$ Polished wide mouth jar with pattern polish on body.

1 Polished outcurving bowl, no supports.

Metepec Zacuala Burial 29

Age-sex unknown.

Provenience: Zacuala Palace (fig. 28).

1 Copa Ware vase, crudely incised, plano-relief decorated with red pigment. MNA 9-3033.

1 Copa ware vase in yellowish-brown with round hollow supports. Diam. at rim $18.5 \mathrm{~cm}$, at base $9.5 \mathrm{~cm}$, ht. $10.4 \mathrm{~cm}$ MNA 9-4320 1/8.

1 Copa Ware vase in light brown. Size same as above. MNA 9-4320 8/8.

1 Copa Ware vase with hollow rounded cylindrical supports. Diam. at rim $10.5 \mathrm{~cm}$, at base $9.5 \mathrm{~cm}$, ht $11 \mathrm{~cm}$ MNA 9-4320 6/8.

3 Polished outcurving bowls.

1 Figurine. 


\section{LIST OF BURIALS FROM YAYAHUALA COMPOUND}

(From Séjourné 1966a; Bennyhoff 1964-1966)

Late Tlamimilolpa Yayahuala Burial 10

Adult female; second individual unidentified.

Provenience: Yayahuala (fig. 29).

1 Polished brown outcurving bowl with inset nubbins, finely incised cloud motif. MNA 9-4329 3/5.

2 Polished brown outcurving bowls similar to above (not located).

Late Tlamimilolpa Yayahuala Burial 25

Individual unidentified.

Provenience: Yayahuala (fig. 29).

1 Polished black outcurving bowl with vestigial nubbins. $\mathrm{Ht} .5 \mathrm{~cm}$, at rim $16 \mathrm{~cm}$, at base $11 \mathrm{~cm}$ MNA 9-4329 5/5.

(Other 5 vessels not located)

Late Tlamimilolpa Yayahuala Burial 26

Individual unidentified.

Provenience: Yayahuala (fig. 29).

1 Polished (restored) groove incised dark brown outcurving bowl with nubbin supports. Ht. $5.2 \mathrm{~cm}$, diameter at rim, $17.3 \mathrm{~cm}$, at base $12 \mathrm{~cm}$ MNA 9-4343 1/2.

(Second vessel not located in museum)

Early Xolalpan Yayahuala Burial 13

Adult Female.

Provenience: Yayahuala (fig. 29).

1 Polished flaring bowl, crudely formed, light brown. $\mathrm{Ht} .6 \mathrm{~cm}$, diam. at rim $17 \mathrm{~cm}$, at base $11 \mathrm{~cm}$ MNA 9-4329 2/5.

5 Similar vessels (not located) 
Early Xolalpan Yayahuala Burial 14

Individual unidentified.

Provenience: Yayahuala (fig 29; Bennyhoff 1964-1966).

1 Cylindrical vase with bosses around base round follow pointed supports. MNA 9-2710.

1 Lid for above vase. MNA 9-2710 A.

2 Painted Specular red upright bowls with dark brown interiors: (a) $\mathrm{Ht} .5 \mathrm{~cm}$ diam. at rim $12.9 \mathrm{~cm}$, at base $9.2 \mathrm{~cm}$ MNA 9-4424 (b) $\mathrm{Ht} .4 .8 \mathrm{~cm}$, diam. at rim $13 \mathrm{~cm}$, at base $10 \mathrm{~cm}$ MNA 9-4424.

$2 \quad$ Matte miniature plates.

2 Low Polish miniature vase, red rim.

3 Matte miniature jars.

$1 \quad$ Matte miniature vase.

Early Xolalpan Yayahuala Burial 15

Age-sex unknown.

Provenience: Yayahuala (fig. 29).

1 Painted red on yellowish brown outcurving bowl with well formed inset nubbins. (Possible Late Tlamimilolpa phase vessel). Ht. $5 \mathrm{~cm}$, diam. at rim $16 \mathrm{~cm}$, at base $10 \mathrm{~cm}$ MNA 9-4329 4/5.

1 Low Polish outcurving bowl. Ht. $5 \mathrm{~cm}$ Diameter at rim $18 \mathrm{~cm}$, at base $11.5 \mathrm{~cm}$ MNA 9-4329 4/5.

1 Low Polish outcurving bowl. Ht. $3.8 \mathrm{~cm}$, diam. at rim $15.5 \mathrm{~cm}$, at base $10 \mathrm{~cm}$ MNA 9-4380.

1 Matte dish, irregular. Ht. $2 \mathrm{~cm}$, diam. at rim $14 \mathrm{~cm}$, at base $10 \mathrm{~cm}$ MNA 9-4350.

Early Xolalpan Yayahuala Burial 16

Individual Unidentified.

Provenience: Yayahuala (fig. 29).

1 Copoid cylindrical vase with round hollow supports. MNA 9-2812.

1 Polished black vase with hollow globular supports with rattles. $\mathrm{Ht} .12 \mathrm{~cm}$, diam. at rim $12 \mathrm{~cm}$, at base $9.6 \mathrm{~cm}$ MNA 9-2889.

1 Polished vase, no supports. MNA 9-2854. 


\section{Late Xolalapan Yayahuala Burial 4}

Adult female and child.

Provenience: Yayahuala (fig. 29).

1 Copa ware vase with 3 molded slab supports in light brown. Traces of cinnabar on exterior. Ht. $13 \mathrm{~cm}$, diam. at rim $13.5 \mathrm{~cm}$, base $12 \mathrm{~cm}$ MNA 9-2971.

1 Copa ware vase with 3 hollow round supports. Light brown with two red spots on upper wall. Ht. $11.2 \mathrm{~cm}$, diam. at rim $11.7 \mathrm{~cm}$, at base $10.9 \mathrm{~cm}$ MNA 9-2964.

1 Copa ware vase, same size as above. MNA 9-3033.

1 Copa ware vase (restored) with 3 hollow round supports. $\mathrm{Ht} .9 \mathrm{~cm}$, diam. at rim $11.3 \mathrm{~cm}$, at base $10.4 \mathrm{~cm}$ MNA 9-2960.

1 Polished (poorly) obtuse angle outcurving bowl with crude "stick polish" interior design. Ht. at rim $16.5 \mathrm{~cm}$, at base $9 \mathrm{~cm}$ MNA 9-2982.

1 Similar to above (not located).

1 Thin Orange cylindrical vase with tab supports, crude punctate and incised lines. Ht. 9 $\mathrm{cm}$, diam. at rim $10.7 \mathrm{~cm}$, at base $8.5 \mathrm{~cm}$ Burnt. MNA 9-2862.

2 Poorly polished (almost matte) wide mouth, crude offset nubbins. Diam. at rim $13 \mathrm{~cm}$, at base $7 \mathrm{~cm}$ MNA 9-2955.

1 Thin Orange hemispherical bowl with incised punctate decoration (not located).

3 Miniatures, low burnished, crater form.

1 Red on natural miniature flaring bowl.

$1 \quad$ Matte miniature "dimpled" saucer.

$1 \quad$ Matte miniature 3 prong, burner.

3 Matte miniature plates.

3 Matte miniature ollitas.

$1 \quad$ Matte miniature handled jar.

$1 \quad$ miniature metate.

5 perforated shells.

2 shell beads.

1 figurine. 
1 tubular shell bead.

3 perforated shells.

\section{Metepec Yayahuala Burial 12}

1 Adult Female; 1 unidentified.

Provenience: Yayahuala (fig. 29; Bennyhoff 1964-1966).

1 Polished crudely incised cylindrical vase with white postfire paint and round hollow bud-like supports. MNA 9-2337 and 9-2764.

1 Matte jar, globular body and everted rim. $\mathrm{Ht} .10 \mathrm{~cm}$, diam. at rim $11.4 \mathrm{~cm}$, at base $8.4 \mathrm{~cm}$ MNA 9-4532.

$2 \quad$ Matte miniature flaring plates.

YAYAHUALA BURIAL, TMP PIT 26A

(Starbuck 1973)

Metepec Yayahuala Burial 1, TMP Pit 26A

1 Adult.

Provenience: Yayahuala Compound, small rear room, southeast corner (fig. 29).

1 San Martin Orange basin with scraped surface and pocked base. Diam. at rim $17 \mathrm{~cm}$, ht $9 \mathrm{~cm}$

1 Polished thick-walled ring base bowl, burnt (fragment).

4 Candeleros.

Slate fragments. 


\section{BURIALS AND OFFERINGS FROM THE TLAJINGA 33:S3W1 COMPOUND}

(From Sanders, Storey and Widmer 1982; Rattray 1983; Widmer 1987a)

\section{EARLY TLAMIMILOLPA BURIALS}

Early Tlamimilolpa Tlajinga 33 Burial 6

1 Adult.

Provenience: Courtyard 1, Lot 204 (fig. 8; Widmer 1987a, fig. 1).

1 Polished dark brown fluted squat jar with flaring rim. Diam. at rim $12.5 \mathrm{~cm}$, ht. $10 \mathrm{~cm}$ (Vessel 2).

1 Polished dark brown flared rim, vague neck jar. Diam. at rim $12.5 \mathrm{~cm}$, ht. $14 \mathrm{~cm}$ (Vessel 1).

1 Shell bead.

1 Shell bead, notched.

Early Tlamimilolpa Tlajinga 33 Burial 10

1 Perinatal.

Provenience: Room 74, Lot 273 (fig. 8).

1 Polished brown-black outcurving bowl with nubbin supports. Diam. at rim $20 \mathrm{~cm}$, ht. $6 \mathrm{~cm}$

1 Polished outcurving bowl with red border. Diam. at rim $10.5 \mathrm{~cm}$, at base $7 \mathrm{~cm}$, ht. $3 \mathrm{~cm}$

1 Polished orange bowl with rounded base (Thin Orange imitation). Diam. at rim $21.5 \mathrm{~cm}$, at base $7.5 \mathrm{~cm}$, ht. $6 \mathrm{~cm}$

1 Polished Lustrous Brown outcurving bowl with large nubbins (possible Miccaotli phase). Diam. at rim. $20 \mathrm{~cm}$, ht. $6 \mathrm{~cm}$

$5 \quad$ Green obsidian prismatic blades (unused) inside bowls.

Early Tlamimilolpa Burial 31

Perinatal.

Provenience: Enclosed yard, Lot 554 (fig. 8).

1 Low Polish interior, matte exterior bowl shaped like cover-plate, smudged both sides. Diam. at rim $24 \mathrm{~cm}$, at base $8 \mathrm{~cm}$; ht. $6.3 \mathrm{~cm}$ (Vessel 1). 
Polished outcurving bowl with nubbin supports. Diam. at rim $10.5 \mathrm{~cm}$, at base $7.5 \mathrm{~cm}$, ht. $2.3 \mathrm{~cm}$

Polished outcurving bowl. Diam. at rim $11.2 \mathrm{~cm}$, at base $7.5 \mathrm{~cm}$, ht. $2.5 \mathrm{~cm}$, ht. $2.5 \mathrm{~cm}$

Polished outcurving bowl with thick walls. Diam. at rim $11 \mathrm{~cm}$, at base $7.3 \mathrm{~cm}, \mathrm{ht} .2 .3 \mathrm{~cm}$

Polished outcurving bowl with everted rim. Diam.at rim $16 \mathrm{~cm}$, at base $12.2 \mathrm{~cm}$,

ht. $4.2 \mathrm{~cm}$

Polished black outcurving bowl with everted rim (fragments).

5 Polished black-brown flaring bowls with nubbin supports: (1) diam. at rim $12.5 \mathrm{~cm}$, at base $9 \mathrm{~cm}$, ht. $3.3 \mathrm{~cm}$ (2) diam. at rim $11.3 \mathrm{~cm}$, at base $7 \mathrm{~cm}$, ht $2.8 \mathrm{~cm}$

(3) diam. at rim $13 \mathrm{~cm}$, at base $9 \mathrm{~cm}$, ht $4.2 \mathrm{~cm}$ (4) diam. at rim $12 \mathrm{~cm}$, at base $9 \mathrm{~cm}$, ht $3.3 \mathrm{~cm}(5)$ diam. at rim $11.5 \mathrm{~cm}$, at base $8 \mathrm{~cm}$, ht. $3.8 \mathrm{~cm}$

Low Polished upright brown-black bowl. Diam. at rim $11 \mathrm{~cm}$, at base, $7.5 \mathrm{~cm}$, ht. $2.3 \mathrm{~cm}$

Low Polished crudely formed flaring bowl. Diam. at rim, $9.5 \mathrm{~cm}$, at base $6.5 \mathrm{~cm}$, ht. $2.3 \mathrm{~cm}$

Polished black vase with flaring rim and slightly insloping body walls. Diam. at rim $6 \mathrm{~cm}$, at base $6.5 \mathrm{~cm}$, ht. $11.3 \mathrm{~cm}$

Polished black 3-handled cantaro (jar). Diam. at rim $6 \mathrm{~cm}$, at base $5 \mathrm{~cm}$, ht. $9.1 \mathrm{~cm}$

Thin Orange outcurving bowl with everted rim. Diam. at rim $15.4 \mathrm{~cm}$, at base $12.5 \mathrm{~cm}$, ht. $4.2 \mathrm{~cm}$

Polished black florero with horizontal rim. Diam. at rim, $10.3 \mathrm{~cm}$, neck $2.5 \mathrm{~cm}$, body $7.1 \mathrm{~cm}$, ht. $6 \mathrm{~cm}$

3 Dense Orange shouldered slightly incurved bowls (1) diam. at rim $5.2 \mathrm{~cm}$, ht. $3.6 \mathrm{~cm}$ (2) diam. at rim $6.2 \mathrm{~cm}$, ht. $4.2 \mathrm{~cm}$; (3) diam. at rim $7 \mathrm{~cm}$, ht. $2 \mathrm{~cm}$

7 Polished Orange incurved bowls with pale red borders: Diam. at rim 7.9, 8, 8.9, 9.2, 9.3, $10.5,11.2 \mathrm{~cm}$; at base $2.5,3,4,4,4.5,4.5,5.5 \mathrm{~cm}$; ht. $3.7,4,4.7,5.3,5.2,5.6,5.7 \mathrm{~cm}$

1 Polished specular red rim on orange corrugated and shouldered bowl. Diam. at rim $9 \mathrm{~cm}$, at base $4 \mathrm{~cm}$, ht. $4.5 \mathrm{~cm}$

1 Polished black incurved bowl with offset nubbins. Diam. at rim $14 \mathrm{~cm}$, at base $8 \mathrm{~cm}$, ht. $6 \mathrm{~cm}$

3 Polished brown incurved bowls with offset nubbins: diam at rim 8, 9, $10.5 \mathrm{~cm}$; at base $6,6.5,7.5 \mathrm{~cm}$; ht. $4.3,4.8,6.8 \mathrm{~cm}$ 


\section{Early Tlamimilolpa Burial 57}

1 Adult.

Provenience: Room 66 (fig. 8).

3 Polished outcurving bowls.

1 Burnished olla.

3 Shell fragments.

3 Shell pendants (small).

2 Shell disks in rattlesnake form.

$2 \quad$ Shell filigree disks.

4,000 Olivella painted, drilled beads.

2 Greenstone beads.

Early Tlamimilolpa Burials 60a, 60c, 60d

3 Adults.

Provenience: Room 68 (fig. 8).

1 Polished widemouth jar.

$7 \quad$ Polished outcurving bowls.

Early Tlamimilolpa Offering 39

1 Burnished cazuela, recurved. Diam. at rim $17 \mathrm{~cm}$, ht. $8 \mathrm{~cm}$

1 Polished outcurving bowl, groove-incised decoration. Diam. at rim $22 \mathrm{~cm}$, at base $16.6 \mathrm{~cm}$, ht. $6.5 \mathrm{~cm}$

1 Polished outcurving bowl with flat nubbins. Diam at rim $24 \mathrm{~cm}$, at base $18 \mathrm{~cm}, \mathrm{ht} .7 \mathrm{~cm}$

1 Polished brown outcurving bowl, diam. at rim $22 \mathrm{~cm}$, at base $14 \mathrm{~cm}$, ht. $6.8 \mathrm{~cm}$

1 Polished brown outcurving bowl, diam. at rim $11 \mathrm{~cm}$, at base $7 \mathrm{~cm}$, ht. $4 \mathrm{~cm}$

1 Polished vase. Diam. at rim $20 \mathrm{~cm}$, ht. $16 \mathrm{~cm}$

10 Low Polished black incurved bowls, diam. at rim $7 \mathrm{~cm}$, ht. $3.5 \mathrm{~cm}$

2 Low Polished orange corrugated, incurved bowls, diam. at rim $6.5 \mathrm{~cm}$, ht. $3 \mathrm{~cm}$ 


\section{TLAJINGA 33 COMPOUND: LATE TLAMIMILOLPA BURIALS}

Late Tlamimilolpa Burial 11

1 Adult.

Provenience: "Outside compound wall", Lot 299 (fig. 8).

1 Polished black outcurving bowl with inset nubbins and rounded basal angle (interior spalled). Diam. at rim $16 \mathrm{~cm}$, at base $10.5 \mathrm{~cm}$, ht. $3.5 \mathrm{~cm}$

1 Polished tan outcurving bowl with thick walls. Diam. at rim $12.5 \mathrm{~cm}$, base $7 \mathrm{~cm}$, ht. $4.5 \mathrm{~cm}$

5 Fine Matte bowls in graduated sizes (stackable). Diam. at rim $11 \mathrm{~cm}, 10.5 \mathrm{~cm}, 9.5 \mathrm{~cm}$, $7 \mathrm{~cm}, 6 \mathrm{~cm}$; ht. $4.5 \mathrm{~cm}, 3 \mathrm{~cm}, 2.5 \mathrm{~cm}, 2 \mathrm{~cm}, 2 \mathrm{~cm}$

4 Fine Matte tan miniature incurved bowls with rounded bases. Diam. at $\operatorname{rim} 5.5 \mathrm{~cm}$, ht. $3 \mathrm{~cm}$

1 Fine Matte orange miniature, interior semi-polished. Diam. at rim $9 \mathrm{~cm}$, ht. $4 \mathrm{~cm}$

1 Fine Matte corrugated miniature. Diam. at rim $6 \mathrm{~cm}$, ht. $4 \mathrm{~cm}$

$4 \quad$ Green obsidian blade fragments.

Late Tlamimilolpa Burial 14

1 Adult.

Provenience: Room 74 (fig. 8).

1 Polished outcurving bowl with small flush nubbins. Diam. at rim $10.5 \mathrm{~cm}$, at base $6.5 \mathrm{~cm}$, ht. $3.3 \mathrm{~cm}$ (vessel 7).

1 Polished outcurving bowl with nubbin supports. Diam. at rim $9.6 \mathrm{~cm}$, at base $6.2 \mathrm{~cm}$, ht. $3 \mathrm{~cm}$ (vessel 9).

1 Polished outcurving bowl with nubbin supports. Diam. at rim $11.4 \mathrm{~cm}$, at base $7.6 \mathrm{~cm}$, ht. $3.8 \mathrm{~cm}$ (vessel 6).

1 Painted red on natural outcurving bowl with nubbin supports. Diam. at rim $11.4 \mathrm{~cm}$, at base $7.6 \mathrm{~cm}$, ht. $3.8 \mathrm{~cm}$ (vessel 1).

1 Painted outcurving bowl with rounded basal juncture. Diam. at rim $13.7 \mathrm{~cm}$, at base $7 \mathrm{~cm}$, ht. $3.5 \mathrm{~cm}$ (vessel 8).

1 Polished outcurving bowl with nubbin supports. Diam. at rim 13.7, at base $10 \mathrm{~cm}$, ht. $4 \mathrm{~cm}$

1 Polished flaring bowl with outcurved rim. Diam. at rim $10.8 \mathrm{~cm}$, at base $6.5 \mathrm{~cm}$, ht. $3 \mathrm{~cm}$ (vessel 11). 
2 Low Polished light brown incurving bowls with rounded bases: (1) Diam. at rim $3.7 \mathrm{~cm}$, at base $4.5 \mathrm{~cm}$, ht. $3.8 \mathrm{~cm}$ (vessel 12) (2) Diam. at rim $6.7 \mathrm{~cm}$, at base $3.5 \mathrm{~cm}$, ht. $3.7 \mathrm{~cm}$ (vessel 3).

1 Polished black incurved rim miniature with thick walls and rounded base. Diam. at rim $6.3 \mathrm{~cm}$, ht. $3.2 \mathrm{~cm}$ (vessel 5).

1 Polished brown incised bowl with rounded base. Diam. at rim $6 \mathrm{~cm}, \mathrm{ht} .3 \mathrm{~cm}$

1 Low Polished orange incurved bowl. Diam. at rim $7.5 \mathrm{~cm}$, at base $3 \mathrm{~cm}$, ht. $3.4 \mathrm{~cm}$

1 Polished black outcurving bowl (vessel 18, fragment).

1 Low Polished simple bowl with bevelled rim. Diam. at rim $7.2 \mathrm{~cm}$, at base $3.2 \mathrm{~cm}$, ht. $3.5 \mathrm{~cm}$ (vessel 10).

2 Clay beads.

Late Tlamimilolpa Burial 18

1 Adult, secondary.

Provenience: Room 92 (fig. 8).

1 Polished outcurving bowl with small nubbins. Diam. at rim $10.2 \mathrm{~cm}$, at base $6.3 \mathrm{~cm}$, ht. $3.3 \mathrm{~cm}$

1 Obsidian point.

Late Tlamimilolpa Burial 21d

1 Perinatal.

Provenience: Coutyard 2 (fig. 8).

$1 \quad$ Polished tan outcurving bowl with crudely scraped exterior and "vestigial" nubbins. Diam. at rim $24 \mathrm{~cm}$, at base $15 \mathrm{~cm}$, ht. $9.4 \mathrm{~cm}$ (Lot 462 ).

1 Polished outcurving bowl with gouge-incised cloud motif. Diam. at rim $20 \mathrm{~cm}$, at base $16 \mathrm{~cm}$, ht. $8 \mathrm{~cm}$

1 Polished outcurving bowl with nubbin supports. Diam. at $\operatorname{rim} 25 \mathrm{~cm}$, at base $17 \mathrm{~cm}$, ht. $7.5 \mathrm{~cm}$

Late Tlamimilolpa Burial 25

1 Adult.

Provenience: Room 33, Lot 493 (fig. 8).

1 Burnished orange krater (prototype for San Martín Orange). Diam. at rim $21 \mathrm{~cm}$, at base $13 \mathrm{~cm}$, ht. $14 \mathrm{~cm}$ 
1 Polished black ring base bowl (Thin Orange imitation). Diam. at rim $17 \mathrm{~cm}$, ring base $7 \mathrm{~cm}$, ht. $5 \mathrm{~cm}$ (incomplete).

1 Polished black miniature gadrooned jar with hollow globular supports.

1 Polished black-brown lightly fluted jar with flared rim and large globular rattle supports. Diam. at rim $9.5 \mathrm{~cm}$, at base $10 \mathrm{~cm}$, ht. $10 \mathrm{~cm}$

1 Polished outcurving bowl with nubbin supports.

8 Low Polished orange incurved bowls. Diam. at rim $9 \mathrm{~cm}, 8 \mathrm{~cm}, 7.5 \mathrm{~cm}$, ht. $3.5 \mathrm{~cm}, 4 \mathrm{~cm}$

2 Fine Matte jars (fragments).

2 Fine Matte bowls. Diam. at rim $11.5 \mathrm{~cm}, 11 \mathrm{~cm}$, ht. $2.5 \mathrm{~cm}, 2 \mathrm{~cm}$

1 Polished fluted upright bowl. Diam. at rim $15 \mathrm{~cm}$, rounded base, ht. $6 \mathrm{~cm}$

1 Painted specular red recurved bowl with slightly everted lip. Diam. at rim $6.5 \mathrm{~cm}$, at base $13 \mathrm{~cm}$, ht. $6 \mathrm{~cm}$

1 Polished brown outcurving bowl with ring base. Diam. at rim $13 \mathrm{~cm}$ ring base $9 \mathrm{~cm}$, ht. $4 \mathrm{~cm}$

2 Reworked sherd polishers.

1 Green stone bead, perforated.

1 Bone bead, perforated.

1 Bone needle.

1 Bone awl (burnt and broken).

1 Stone metate (pale red). Diam. at rim $8.5 \mathrm{~cm}$, ht. $1.8 \mathrm{~cm}$

1 Stone mano, length $8.5 \mathrm{~cm}$

Late Tlamimilolpa Burial 28a

1 Child.

Provenience: Enclosed yard (fig. 8).

1 Polished outcurving bowl, crude. Diam. at rim $23 \mathrm{~cm}$, at base $13 \mathrm{~cm}$, ht. $9 \mathrm{~cm}$

1 Polished outcurving bowl. 
Late Tlamimilolpa Burial 29a

1 Perinatal.

Provenience: Outside compound (fig. 8).

1 Thin Orange bowl

Late Tlamimilolpa Burial 32

1 Perinatal.

Provenience: Room 92, Lot 500 (fig. 8).

1 Polished brown outcurving bowl with "vestigial" nubbins. Diam. at rim $23 \mathrm{~cm}$, at base $16 \mathrm{~cm}$, ht. $6.5 \mathrm{~cm}$

1 Polished flaring bowl with vestigial supports. Diam. at $\operatorname{rim} 21 \mathrm{~cm}$, at base $11.5 \mathrm{~cm}$, ht. $9 \mathrm{~cm}$

1 Green Obsidian prismatic blade.

Late Tlamimilolpa Burial 35

1 Adult.

Provenience: Room 84,Lot 586 (fig. 8).

2 Fine Matte outcurving bowls. Diam. at rim $10 \mathrm{~cm}$, ht. $2 \mathrm{~cm}$

1 Clay duck (frag.).

1 Clay pipe.

1 Green obsidian blade.

1 Green obsidian point (crude).

Late Tlamimilolpa Burials 42a, 42b

2 Adults, primaries.

Provenience: Enclosed yard, Lots 461, 624 (fig. 8).

1 Polished outcurving bowl. Diam. at rim $11 \mathrm{~cm}$, at base $8 \mathrm{~cm}$, ht. $3.5 \mathrm{~cm}$ (Lot 461 , vessel 18).

2 Polished outcurving bowls with "vestigial" nubbins: (1) Diam. at rim $14 \mathrm{~cm}$, at base $8.5 \mathrm{~cm}$, ht. $5 \mathrm{~cm}$ (Lot 624, vessel 6) (2) Diam. at rim $11.4 \mathrm{~cm}$, ht. $4 \mathrm{~cm}$ (Lot 624, vessel 13).

1 Polished pale brown outcurving bowl with pointed nubbin supports. Diam. at rim $11 \mathrm{~cm}$, ht. $5.5 \mathrm{~cm}$ (Lot 624, vessel 20). 
1 Polished black-brown flaring bowl with nubbins. Diam. at rim $10.5 \mathrm{~cm}$ at base $6 \mathrm{~cm}$, ht. $3 \mathrm{~cm}$ (Lot 624, vessel 12).

1 Polished black-brown flaring bowl without supports. Diam. at rim $10.5 \mathrm{~cm}$, at base $6 \mathrm{~cm}$, ht. $3 \mathrm{~cm}$ (Lot 624, vessel 27).

1 Polished outcurving bowl with support scars. Diam. at rim $11 \mathrm{~cm}$, ht. $6.5 \mathrm{~cm}$ (Lot 624, vessel 5).

1 Polished black-brown outcurving bowl with vestigial nubbins. Diam. at rim $13.5 \mathrm{~cm}$, at base $8.5 \mathrm{~cm}$, ht. $4.5 \mathrm{~cm}$ (Lot 624, vessel 4 ).

3 Polished outcurving bowls without supports. Diam. $9.5 \mathrm{~cm}, 10.5 \mathrm{~cm}, 11 \mathrm{~cm}$, base $5.5 \mathrm{~cm}$, $6 \mathrm{~cm}, 7 \mathrm{~cm}$ (Lot 624, vessels 11, 24 and 26).

3 Dense ware orange incurved bowls with corrugated rims and rounded bases.

Diam. at rim $6.5 \mathrm{~cm}$, ht. $3 \mathrm{~cm}$ (Lot 624 , vessels 7, 10 and 17).

2 Polished incurved bowls. Diam. at rim $8 \mathrm{~cm}$, ht. $3.5 \mathrm{~cm}$ (Lot 624, vessels 9 and 16).

1 Polished incurved brown-black bowl. Diam. at rim $8 \mathrm{~cm}$, ht. $3.5 \mathrm{~cm}$ (Lot 624, vessel 25).

Late Tlamimilolpa Burial 44

1 Adult.

Provenience: Room 53 (fig. 8).

1 Shell bead.

Late Tlamimilolpa Burial 55

Perinatal.

Provenience: Room 65, Lot 755 (fig. 8).

1 Polished orange bowl, crude. Diam. at rim $21.7 \mathrm{~cm}$, at base $16.5 \mathrm{~cm}$, ht. $5.7 \mathrm{~cm}$

2 Obsidian blades.

Late Tlamimilolpa Burial 58

1 Adult.

Provenience: Room 104 (fig. 8).

1 Green stone bead.

1 Shell object, drilled.

Several unreconstructed ceramic vessels. 


\section{Late Tlamimilolpa Burial 64}

1 Perinatal.

Provenience: Room 83, Lot 837 (fig. 8).

1 Polished brown outcurving bowl, crude. Diam. at rim $20 \mathrm{~cm}$, at base $1 \mathrm{~cm}$, ht. $8.8 \mathrm{~cm}$

\section{Late Tlamimilolpa Burial 65}

1 Perinatal.

Provenience: Room 83,Lot 838 (fig. 8).

1 Polished brown outcurving bowl.

1 Polished pale brown outcurving bowl, crude bevelled rim. Diam. at rim $20.5 \mathrm{~cm}$, at base $12 \mathrm{~cm}$, ht. $7.3 \mathrm{~cm}$

Late Tlamimilolpa Burial 66

1 Perinatal.

Provenience: Room 83, Lot 789 (fig. 8).

1 Polished outcurving bowl with incised cloud motif and worn nubbins. Diam. at rim $25 \mathrm{~cm}$, at base $17 \mathrm{~cm}$, ht. $7 \mathrm{~cm}$

Late Tlamimilolpa Burial 70

1 Adult.

Provenience: Room 53 (fig. 8).

$1 \quad$ Slate disk, drilled.

Late Tlamimilolpa Possible Offering 16

Provenience: Lot 398 (fig. 8).

1 Polished brown outcurving bowl with worn nubbins. Diam. at rim $20 \mathrm{~cm}$, at base $13.5 \mathrm{~cm}$ 
TLAJINGA 33 COMPOUND: LATE TLAMIMILOLPA-EARLY XOLALPAN BURIALS

Late Tlamimilolpa-Early Xolalpan Burial 15

1 Adult.

Provenience: Room 33, Lot 375 (fig. 8).

1 Polished widemouth jar with rounded base and nubbin supports. Diam. at rim $17.5 \mathrm{~cm}$, at base $11 \mathrm{~cm}$, ht. $14 \mathrm{~cm}$ (vessel 1).

1 Polished outcurving bowl with pattern-polish criss-cross motif and inset nubbin supports. Diam. at rim $12.2 \mathrm{~cm}$, at base $9.5 \mathrm{~cm}$, ht. $4.7 \mathrm{~cm}$ (vessel 3).

1 Fine Matte outflaring dish with ridged rim. Diam. at rim $11.5 \mathrm{~cm}$, at base $8.5 \mathrm{~cm}$, ht. $2.5 \mathrm{~cm}$ (vessel 5).

2 Fine Matte flaring dishes: (1) Diam. at rim $10.8 \mathrm{~cm}$, at base $7 \mathrm{~cm}$, ht. $2 \mathrm{~cm}$ (2) Diam. at rim $10.5 \mathrm{~cm}$, at base $7 \mathrm{~cm}$, ht. $2.2 \mathrm{~cm}$ (vessel 4).

Mica pieces.

2 Slate pieces, painted.

1 Shell, small.

1 Bone needle.

Late Tlamimilolpa-Early Xolalpan Burial 30b

1 Adult.

Provenience: outside compound (fig. 8).

1 Polished cylindrical vase with basal torus and hollow cylindrical supports.

2 Fine Matte bowls with flaring sides. Diam. at rim $14 \mathrm{~cm}$, ht. $2.5 \mathrm{~cm}$

2 Ground stone polishers ("flatiron" type).

$8 \quad$ Green obsidian prismatic blades.

2 Mica pieces.

1 Slate piece, painted. 


\section{Early Xolalpan Burial 7}

1 Perinatal.

Provenience: Room 33 (fig. 8).

1 Polished pale brown outcurving bowl with everted rim and "vestigial" nubbins. Incised cross on outside bottom, a possible potter's mark. Diam. at rim $21 \mathrm{~cm}$, at base $17 \mathrm{~cm}$, ht. $7 \mathrm{~cm}$

1 Polished outcurving bowl with "vestigial" nubbins and incised cloud motif (Early Tlamimilolpa style). Diam. at rim $21.3 \mathrm{~cm}$, at base $15 \mathrm{~cm}$, ht. $6 \mathrm{~cm}$

\section{Early Xolalpan Burial 39}

1 Perinatal

Provenience: Courtyard 2 (fig. 8).

1 Painted specular red olla (lacks neck). Ht. $20 \mathrm{~cm}$

1 Polished pale brown outcurving bowl with "vestigial" nubbins. Diam. at rim $23 \mathrm{~cm}$, at base $15 \mathrm{~cm}$, ht. $9 \mathrm{~cm}$

Early Xolalpan Burial 59a, 59b

1 Child, 1 Adult.

Provenience: Room 44 (fig. 8).

2 Polished Orange bowls.

Early Xolalpan Burials 60a, 60c, 60d

3 Adults.

Provenience: Room 68 (fig. 8).

1 Polished widemouth jar.

$7 \quad$ Polished outcurving bowls.

1 Greenstone bead. 
Late Xolalpan Burial 2a

1 Perinatal.

Provenience: Room 1 (fig. 8).

1 Burnished reddish brown olla, rimless. Diam. at rim $40 \mathrm{~cm}$, base rounded, ht. 50 to $55 \mathrm{~cm}$

1 Tlajinga ware bowl with exterior border, $1.5 \mathrm{~cm}$ in width. Diam. at $\operatorname{rim} 21 \mathrm{~cm}$, rounded pocked base, ht. $5 \mathrm{~cm}$ Incised design on interior.

2 Green Obsidian subprismatic blades.

1 Slate chip.

Late Xolalpan Burial 3

1 Perinatal.

Provenience: Room 30 (fig. 8).

1 Polished outcurving bowl with obtuse angle base and side. Fire-clouded, matte exterior.

1 Polished outcurving bowl with everted rim (fireburnt). Diam. at rim $22 \mathrm{~cm}$, at base $14.5 \mathrm{~cm}$, ht. $5 \mathrm{~cm}$

1 Polished outcurving bowl with everted rim (fireburnt). Diam. at rim $23.2 \mathrm{~cm}$, at base $15.5 \mathrm{~cm}$, ht. $7.5 \mathrm{~cm}$

Late Xolalpan Burial 5

1 Perinatal.

Provenience: Room 30 (fig. 8).

1 Tlajinga ware outcurving bowl with thick wedge rim and exterior ridge and rounded pocked base. Interior painted red and orange and incised. Diam. at rim $24 \mathrm{~cm}$, ht. $5.7 \mathrm{~cm}$

\section{Late Xolalpan Burial 8}

1 Perinatal.

Provenience: Room 30 (fig. 8).

1 San Martín Orange amphora bottom with pocked base (vessel 2).

1 Polished outcurving bowl with 3 bosses along rim and nubbin supports. Diam. at rim $19 \mathrm{~cm}$, at base $13 \mathrm{~cm}$, ht. $6 \mathrm{~cm}$ 
Late Xolalpan Tlajinga 33 Burial 9

1 Perinatal.

Provenience: Outside compound (fig. 8).

1 Burnished krater, crude, thick walled. Diam. at rim $21 \mathrm{~cm}$, at base $12 \mathrm{~cm}$, ht. $11 \mathrm{~cm}$ (vessel 4).

1 Polished brown outcurving bowl. Diam. at rim $19.5 \mathrm{~cm}$, at base $13.5 \mathrm{~cm}$, ht. $5.5 \mathrm{~cm}$ (vessel 2).

1 Polished crudely finished outcurving bowl. Diam. at rim $20 \mathrm{~cm}$, at base $12.5 \mathrm{~cm}$, ht. $8 \mathrm{~cm}$

2 Green obsidian blades.

Late Xolalpan Tlajinga 33 Burial 17a

1 Child.

Provenience: Room 24 (fig. 8).

1 Shell fragment.

Late Xolalpan Burial 33

1 Perinatal.

Provenience: Room 24 (fig. 8).

1 Polished outcurving bowl, matte exterior, pattern polished interior. Diam. at rim $25 \mathrm{~cm}$, at base $14 \mathrm{~cm}$, ht. $4.5 \mathrm{~cm}$

1 Green obsidian blade.

Late Xolalpan Burials 50a, 50b, 50c, 50d, 50e

5 Adults (Primaries).

Provenience: Courtyard 3 Shaft Tomb, Lot 700 (fig. 8).

1 Stuccoed-Painted cylindrical vase with rectangular cotout supports. Painted motifs consist of flowers and scrolls in red, pink and green on black matte surface. Diam. at base $13 \mathrm{~cm}$, ht. undetermined (vessel 6, incomplete).

1 Thin Orange miniature gadrooned jar. Diam. at rim $4 \mathrm{~cm}$, ht. $3.5 \mathrm{~cm}$

2 Fine Matte outcurving bowls (1 fragmentary). Diam. at rim $15 \mathrm{~cm}$, at base $9 \mathrm{~cm}, \mathrm{ht} .2 \mathrm{~cm}$ (vessel 2).

1 Tlajinga ware outcurving bowl with zig-zag pattern-polish interior. Diam. at rim $13 \mathrm{~cm}$, at base $8 \mathrm{~cm}$, ht. $2.2 \mathrm{~cm}$ (vessel 5). 
1 Tlajinga ware bowl without curving sides. Pattern polish interior. Diam. at rim $24 \mathrm{~cm}$, at base $15 \mathrm{~cm}$, ht. $5.5 \mathrm{~cm}$ (vessel 3).

25 Molded adorno pieces (Early and Late Xolalpan style). Disks, petals, feathered ornaments, plaques, butterflies.

13 Handmade adorno pieces.

1 Coarse Matte incensario flange (Late Xolalpan style) and censer base (fragments).

1 Flared "earspool" coated with yellow ochre. Diam. $6 \mathrm{~cm}$, length $6.5 \mathrm{~cm}$ (Fragment of another "earspool").

27 Green prismatic blades.

30 Green subprismatic blades.

6 Misc. chips.

$1 \quad$ Mica disks.

Mica fragments.

Painted slate fragment.

1 Shell pendant.

Clumps diatomaceous earth.

Late Xolalpan Burial 51

1 Perinatal.

Provenience: Room 28 (fig. 8).

1 Polished outcurving bowl with pattern polish interior design. Diam. at rim $27 \mathrm{~cm}$, at base $16.5 \mathrm{~cm}$, ht. $5 \mathrm{~cm}$ (vessel 2).

1 Tlajinga ware krater with flared top, rounded pocked base and interior pattern-polished. Diam. at rim $21.5 \mathrm{~cm}$, at base $7.5 \mathrm{~cm}$, ht. $6 \mathrm{~cm}$ (vessel 4).

1 Polished outcurving bowl. Diam. at rim $23 \mathrm{~cm}$, at base $15 \mathrm{~cm}$, ht. $5.3 \mathrm{~cm}$ (vessel 1).

1 Tlajinga ware flat-bottomed "flower pot" shape with pocked base. Diam. at rim $23.5 \mathrm{~cm}$, at base $10 \mathrm{~cm}$, ht. $6.2 \mathrm{~cm}$ (vessel 3). 
Late Xolalpan-Metepec Burial 54

1 Child.

Provenience: Room 61 (fig. 8).

1 San Martín Orange ware amphora bottom with scrape-burnish finish and pocked base. (Probable mold). Diam. at rim $17.3 \mathrm{~cm}$, at base $8 \mathrm{~cm}$, ht. $12.5 \mathrm{~cm}$

1 San Martín Orange ware basin, unusually small and crude. Diam. at rim $17.3 \mathrm{~cm}$, at base $11 \mathrm{~cm}$, approx ht. $7 \mathrm{~cm}$ (vessel 2).

2 Figurine heads.

1 Green obsidian blade.

OAXACA BARRIO BURIALS AND OFFERINGS

(Rattray 1981,1986; Spence 1976)

$\underline{\text { Early Xolalpan Skull Burial C }}$

1 Adult (skull and mandible, secondary)

Provenience: Site 7:N1W6, Southeast corner, Pit E1N17 (Fig. 11, 14; University of the Americas' excavation)

Incensario in three parts: base, flanged censerbowl, "thumbed" censer cone. Charcoal and burnt shell inside censer

Artifacts nearby:

$1 \quad$ Bone awl

$1 \quad$ Bone needle

$1 \quad$ Obsidian projectile point

$1 \quad$ Mica disk

$5 \quad$ Slate fragments

2 Figurine heads

\section{Early Xolalpan Redeposited Burial B}

1 Adult (secondary)

Provenience: North end of Compound, Pit W1N24, (Fig. 11; University of the Americas)

Offering of broken and incomplete vessels:

2 Monte Alban II-IIIA Urn parts: 1 headdress, 1 maxtlatl 
1 Oaxaca Gray ware bowl (CBA type G-12)

9 Thin Orange bowls

3 Incensario bases (1 complete)

1 Incensario adorno

$4 \quad$ Painted specular red upright bowls

Misc. Polished ware outcurving and simple bowls

$1 \quad$ Obsidian prismatic blade

1 Jadeite bead

$1 \quad$ Figurine

\section{Late Xolalpan II-IIIA Urn Burials A1, A2, A3}

3 Adults ( 1 male): 2 primaries in extended position; 1 cranium (secondary)

Provenience: South end of Compound, Pits W1N9-W2N9 (Figs. 11, 12, 13; Plate XIII)

University of the Americas)

1 Monte Albán Transición II-IIIA Urn (CBA classification) $\mathrm{Ht} .27 \mathrm{~cm}$, width $17 \mathrm{~cm}$

1 Copa ware vase. Diam. at rim $11 \mathrm{~cm}$, at base $10 \mathrm{~cm}$, ht. $8 \mathrm{~cm}$

1 Polished ware outcurving bowl. Diam. at rim $11.5 \mathrm{~cm}$, at base $8.5 \mathrm{~cm}$, ht. $3.5 \mathrm{~cm}$

1 Polished ware upright bowl. Diam. at rim $22 \mathrm{~cm}$, at base $15 \mathrm{~cm}$, ht. $8 \mathrm{~cm}$

$1 \quad$ Matte miniature ollita

$2 \quad$ Matte miniature clay rolls

1 Matte miniature ollita, ht. $4 \mathrm{~cm}$

$1 \quad$ Obsidian scraper

2 Obsidian prismatic blades

3 Bone tools: 1 ( 2 to $2.2 \mathrm{~cm}$ wide, perforated and pointed; 2 awls)

$1 \quad$ Pyrite mirror

1 Shell ornament

Lumps of red ochre 


\section{Mica fragments}

\section{Charcoal}

\section{Late Xolalpan - Metepec Oaxaca Tomb Burials}

4 Adults: 2 males, 1 female, 1 undetermined; 1 child; 1 perinatal

Provenience: Oaxaca Barrio Tomb (Fig. 11, University of the Americas and TMP excavations). In south-central part of apartment compound

Offering fragments remaining after the looting:

1 Metepec Thin Orange bowl

1 Incensario adorno

1 Fine Gray Oaxaca vase with rounded basal flange

$1 \quad$ Locally made Oaxaca-style bowl

2 Fine Gray micaceous bowls

1 Burnished olla, lacking rim (perinatal's burial receptacle)

Fine Matte miniatures

$1 \quad$ Jadeite bead

1 Pyrite mirror

Mica flakes

Misc. shell

Yellow ochre

Slate fragments

\section{Metepec Monte Albán IIIA Urn Offering}

Provenience: Room under main temple of apartment compound (Fig.11, TMP excavations, Pits W5N18-W5N19)

1 Monte Albán IIIA Urn. Ht. $34 \mathrm{~cm}$ (head $14 \mathrm{~cm}$, arms $20 \mathrm{~cm}$ ); diam. body $10-20 \mathrm{~cm}$ Weight, 3 kilos.

Associated sherds: 5 Metepec Polished outcurving bowls, 1 Thin Orange bowl, 4 Late Xolalpan outcurving bowls, 2 G-2 apaxtles, 1 G-3 bowl 


\author{
BURIALS AND OFFERINGS FROM MERCHANTS' BARRIO, \\ TEOTIHUACAN (SITES 3E, 3W, 9: N3E4; 8, 12: N4E4) \\ (Rattray 1985b; Civera 1989)
}

\title{
MERCHANTS' BARRIO LATE TLAMIMILOLPA BURIALS
}

\section{$\underline{\text { Late Tlamimilolpa Burial } 9}$}

1 Child

Provenience: Site 3E:N3E4, Small Circular Structure \#3, Square W1S3 (fig. 15)

1 Polished orange brown outcurving bowl with nubbin supports. Diam. at $\operatorname{rim} 9 \mathrm{~cm}$, ht. $2.5 \mathrm{~cm}$ (vessel 1)

1 Polished light. brown outcurving bowl with nubbin supports. Diam. at rim $13 \mathrm{~cm}$, ht. $3.1 \mathrm{~cm}$ (vessel 3)

4 Polished light. brown outcurving bowls with nubbin supports. Diam. at rim $9 \mathrm{~cm}$, $10.5 \mathrm{~cm}, 12.5 \mathrm{~cm} 11.7 \mathrm{~cm}$; ht. $3.4 \mathrm{~cm}, 3.8 \mathrm{~cm}, 3.5 \mathrm{~cm}, 3.8 \mathrm{~cm}$ (Vessels 6, 7, 8, 9)

1 Polished orange flaring bowl with nubbin supports (burnt). Diam. at rim $12 \mathrm{~cm}$, ht. $3.7 \mathrm{~cm}$ to $4.0 \mathrm{~cm}$ (vessel 10)

1 Polished brown black flaring bowl. Diam. at rim $13.5 \mathrm{~cm}$, ht. $2.9 \mathrm{~cm}$ (vessel 11)

1 Polished light. brown outcurving bowl with nubbin supports. Diam. at rim $11.5 \mathrm{~cm}$, ht. $4.5 \mathrm{~cm}$ (vessel 12)

2 Polished light. brown outcurving bowls with nubbin supports (burnt). Diam. at rim $11 \mathrm{~cm}, 12 \mathrm{~cm}$; ht. $3.3 \mathrm{~cm}, 3.8 \mathrm{~cm}$ (vessels 14, 15)

1 Polished light. brown outcurving bowl, crude (burnt). Diam. at rim $13 \mathrm{~cm}$, ht. $4.4 \mathrm{~cm}$ (vessel 16, incomplete)

1 Polished dark brown flaring bowl (burnt). Diam. $10.2 \mathrm{~cm}$, ht. $3.7 \mathrm{~cm}$ (vessel 17, incomplete)

1 Polished reddish brown globular jar with flaring rim, 4 handles ( 2 missing) around shoulder alternating with 4 pairs of coffee bean pastillaje adornos (foreign). Diam. at rim $8 \mathrm{~cm}$, ht. $9.5 \mathrm{~cm}$ (vessel 2)

1 Thin Orange bowl with ring base. Diam. at rim $12 \mathrm{~cm}$, ht. $4 \mathrm{~cm}$ (vessel 4)

1 Polished reddish brown composite silhouette jar with flaring neck (burnt). Diam. at rim $6.5 \mathrm{~cm}$, ht. $6.2 \mathrm{~cm}$ (vessel 13)

1 Fine Paste Orange corrugated incurved bowl. Diam. $12.5 \mathrm{~cm}, \mathrm{ht} .6 .4 \mathrm{~cm}$ (vessel 5) 
Late Tlamimilolpa Burial 20-21

Age-sex unknown (1 long bone, vertebra and fragments)

Provenience: Site 8:N4E4, Circular Structure \#10, Adoratorio 4 (Pits emptied and resealed) (fig. 16)

$1 \quad$ Bone celt. Length $8.5 \mathrm{~cm}$, width $2.5 \mathrm{~cm}$

Late Tlamimilolpa Burial 22a, 22b

1 Young adult; 1 child

Provenience: Site 12:N4E4, Square W1S3, Patio beween Circular Structures \#10 and \#11 (fig. 16)

1 Maya Polychrome jar with flaring rim and human and animal figures on body.

Diam. at rim $14 \mathrm{~cm}$, at base $7 \mathrm{~cm}$, maximum diam. $23 \mathrm{~cm}$, ht. $18 \mathrm{~cm}$

1 Maya Polychrome miniature tecomate. Diam. at rim $9 \mathrm{~cm}$, ht. $6 \mathrm{~cm}$

1 Painted red on natural outcurving bowl with nubbin supports. Diam. at rim $15 \mathrm{~cm}$, base $10 \mathrm{~cm}$, ht. $4.5 \mathrm{~cm}$

1 Thin Orange outcurving bowl with corrugated body and nubbin supports.

Diam. $16 \mathrm{~cm}$, at base $12 \mathrm{~cm}$, ht. $2 \mathrm{~cm}$

1 Thin Orange bowl. Diam. $12 \mathrm{~cm}$, base $6 \mathrm{~cm}$, ht. $3 \mathrm{~cm}$

1 Thin Orange recurved bowl, incised. Diam. at rim $15 \mathrm{~cm}$, base $10 \mathrm{~cm}$, ht. $5 \mathrm{~cm}$

1 Thin Orange ringbase bowl with mend hole. Diam. at rim $24 \mathrm{~cm}$

1 Low Polish outcurving bowl with small nubbins. Diam. at rim $12.5 \mathrm{~cm}$, base $8.5 \mathrm{~cm}$, ht. $2.5 \mathrm{~cm}$

1 Low Polish black outcurving bowl. Diam. at rim $11.5 \mathrm{~cm}$, base $6 \mathrm{~cm}$, ht. $2 \mathrm{~cm}$

1 Low Polish, red rim bowl. Diam. at rim $10 \mathrm{~cm}$, base $5.5 \mathrm{~cm}$, ht. $2 \mathrm{~cm}$

1 Low Polish bowl with small nubbins. Diam. $8.5 \mathrm{~cm}$, base $5.5 \mathrm{~cm}$, ht. $2 \mathrm{~cm}$

1 Matte composite silhouette florero Diam. at rim $7.5 \mathrm{~cm}$, maximum diam. $8 \mathrm{~cm}$, ht. $7.5 \mathrm{~cm}$

1 Fine Paste Orange corrugated bi-pinched bowl. Diam. at rim $9-10 \mathrm{~cm}$, ht. $4 \mathrm{~cm}$

$1 \quad$ Jade bead

$1 \quad$ Obsidian projectile point

2 Obsidian green prismatic blades 
1 Obsidian green blade, complete

1 Caracol, perforated; Misc. shell beads

1 clay miniature metate

$1 \quad$ Bone needle

Red ochre

\section{Late Tlamimilolpa Burial 23}

Age-sex unknown

Provenience: Site 12:N4E4, Square W1S3, below patio area or room (fig. 16)

1 Stone polisher (well formed) with red pigment. Width $10 \mathrm{~cm}$, length $11 \mathrm{~cm}$, thickness $4 \mathrm{~cm}$

1 Thin Orange recurved bowl with incised motif and dashed lines

1 Coarse Matte stove prong (fragment)

$1 \quad$ Shell

Pieces of slate

Late Tlamimilolpa Offering 6

Provenience: Site 12:N4E4, Square W1S1, B2-3 (next to possible oven) (fig. 16)

1 Polished reddish brown jar with conical nubbins. Diam. at rim $14 \mathrm{~cm}$, base $11 \mathrm{~cm}$, ht. $12 \mathrm{~cm}$

$1 \quad$ Polished black widemouth jar with fluted body and small nubbin supports.

Diam. at rim $14 \mathrm{~cm}$, base $9.5 \mathrm{~cm}$, ht. $13 \mathrm{~cm}$

1 Fine Matte plate. Diam. at rim $8.5 \mathrm{~cm}$, base $6 \mathrm{~cm}$, ht. $1.2 \mathrm{~cm}$

1 Low Polish outcurving bowl, matte exterior. Diam. at rim $9.5 \mathrm{~cm}$, base $6.5 \mathrm{~cm}$, ht. $2.5 \mathrm{~cm}$

1 Fine Matte orange bowl, burnt. Diam. at rim $12.5 \mathrm{~cm}$, base $8.5 \mathrm{~cm}$, ht. $2.2 \mathrm{~cm}$

1 Dense ware corrugated tecomate (incurved bowl) with thick walls (fragment)

1 Stone mano. $8 \mathrm{~cm}$ long, diam. $7 \mathrm{~cm}$ 


\section{MERCHANTS' BARRIO EARLY XOLALPAN BURIALS}

\section{Early Xolalpan Burial 2}

1 Perinatal, 1 middle aged adult

Provenience: Site 3E:N3E4, North Platform in adobe "box" construction (fig. 15)

1 Thin Orange ringbase bowl (bones and shell figures inside). Diam. at rim $22 \mathrm{~cm}$, ht. $7.2 \mathrm{~cm}$

1 Thin Orange bowl (approx. one-half). Diam. at rim $22 \mathrm{~cm}$, ht. $7.2 \mathrm{~cm}$

1 Shell necklace. Diam. of beads $5 \mathrm{~mm}$

7 Shell anthropomorphic figurines. Ht. $3.5 \mathrm{~cm}, 3 \mathrm{~cm}, 2.5 \mathrm{~cm}(2), 1.5 \mathrm{~cm}(2), 1 \mathrm{~cm}$

\section{Early Xolalpan Burial 4}

Middle aged adult, possible incineration

Provenience: Site 3E:N3E4, Circular Structure \#2, Square E1N5 (fig. 15)

1 Copa ware vase. Diam. at rim $12 \mathrm{~cm}$, base $10 \mathrm{~cm}$, ht. $10.5 \mathrm{~cm}$

1 Low Polished light. brown outcurving bowl. Diam. at rim $13 \mathrm{~cm}$, base $8 \mathrm{~cm}$, ht. $2 \mathrm{~cm}$

1 Low Polished miniature bowl fragment

$1 \quad$ Stuccoed effigy jar fragment (Gulf Coast)

1 Lustrous ware cream-colored plano-relief vase with "Tajin scroll" motif (fragment)

1 Fine Paste Gray spouted jar fragment. Diam. of tube $2 \mathrm{~cm}$

\section{Early Xolalpan Burials $5-8$}

34 Individuals: 2 perinatals, 7 infants, 3 youths, 3 sub-adults, 6 young adults, 9 middle-aged adults, 4 advanced age (10 male, 11 female; 1 young female, primary; remainder, secondary).

Provenience: Site 3E:N3E4. Large Burial Pit, Circular Structure \#2. Squares E1N5-E2N5 (fig.15)

1 Copa Ware copa. Diam. at rim $9 \mathrm{~cm}$, ht. $14 \mathrm{~cm}$

1 Copa ware copa with lizard applique. Diam. at rim $9 \mathrm{~cm}$, ht. $14 \mathrm{~cm}$

2 Copa ware vase, incised. Diam. at rim $13 \mathrm{~cm}$, ht. $12 \mathrm{~cm}$

2 Polished ware vases (incomplete) 
3 Polished ware lids (incomplete)

1 Fine Paste Incised White Slip vase. Diam. at rim $29 \mathrm{~cm}$

1 Unidentified foreign black jar

1 Candelero

$1 \quad$ Jade pendant on pyrite backing

15 pieces jade

1 Shell disk, perforated

1 Shell necklace, some elongated pieces (Spondylus Americanus)

1 Shell pendant

1 Piece ambar

$4 \quad$ Bone disks

$1 \quad$ Bone weaving pick

2 Bone needles

Mica fragments

2 Polished trianglar-shaped pieces of reddish material, probably hematite

Serpentine fragments

\section{$\underline{\text { Early Xolalpan Burial } 14}$}

1 Fetus, 1 child, 2 adults: 1 male, 1 young female

Provenience: Site 3W:N3E4, Square W2N6, Shrine 2 (fig. 15,19)

1 Polished brown-black cylindrical vase with hollow cylindrical supports and bosses around base. Diam. at rim $11.5 \mathrm{~cm}$, ht. $10.5 \mathrm{~cm}$

1 Polished brown-black cylindrical vase similar to above. Diam. $13.5 \mathrm{~cm}$, ht. $10.5 \mathrm{~cm}$

2 Polished black lids with knobs. Diam. $14 \mathrm{~cm}$

1 Polished outcurving bowl. Diam. $9 \mathrm{~cm}$

$1 \quad$ Polished outcurving bowl, streak polished

2 Polished widemouth jars with "stick-polished" bodies and necks. (1) Diam. at rim $20 \mathrm{~cm}$, neck ht. $8.5 \mathrm{~cm}$ (2) Diam. at rim $18 \mathrm{~cm}$ 
9 Low Polish small vessels. Approx. diam. 10-11 cm

1 Thin Orange jar with globular body. Diam. at neck $14 \mathrm{~cm}$, body $18 \mathrm{~cm}$

1 Thin Orange bowl.Diam. at rim $11 \mathrm{~cm}$, ht. $2.5 \mathrm{~cm}$

\section{Early Xolalpan Burials 24-25}

4 Individuals: 3 males, 2 advanced-age; 1 male middle-age; 1 young female

Provenience: Site 3E:N3E4, Square W1S5, Circular Structure \# 12, Shrine 3 (fig. 15)

2 Stone candeleros: (1) length $7 \mathrm{~cm}$, width $4.4 \mathrm{~cm}$, ht. $3.5 \mathrm{~cm}$; (2) length $5 \mathrm{~cm}$, width $4 \mathrm{~cm}$, ht. $3.5 \mathrm{~cm}$

1 Stone mano and metate (grinding tools). Metate length $23 \mathrm{~cm}$, width $15 \mathrm{~cm}$, ht. $3 \mathrm{~cm}$, mano length $21.5 \mathrm{~cm}$

1 Copa ware copa. Diam. at rim $8.5 \mathrm{~cm}$, base $5.5 \mathrm{~cm}$, ht. $12.5 \mathrm{~cm}$

Shell, mica and slate pieces

Possible ambar

Charcoal

\section{Early Xolalpan Burial 26}

1 Female?, young adult

Provenience: Site 3E:N3E4, Square W1S5, Shrine 3 (fig. 15)

1 Polished brown corrugated cylindrical vase. Diam. $13.5 \mathrm{~cm}$, ht. $11 \mathrm{~cm}$

2 Fine Matte plates. (1) Diam. at rim $11 \mathrm{~cm}$ (2) Diam. at rim $13 \mathrm{~cm}$

1 Fine Matte miniature incurved bowl. Diam. at rim $4 \mathrm{~cm}$, ht. $1.2 \mathrm{~cm}$

1 Low Polish outcurving bowl. Diam. at rim $11 \mathrm{~cm}$

12 Clay "finger rolls". 1 to $2 \mathrm{~cm}$ long

1 Clay candelero, incised. Length $5.5 \mathrm{~cm}$, height. $4 \mathrm{~cm}$

1 Pyrite disk (bevelled edges,perforated) with thick yellow pigment; opposite side, red pigment. Diam. $14.5 \mathrm{~cm}$

$1 \quad$ Green Obsidian projectile point

1 Notched bone object. Length $8 \mathrm{~cm}$, width $2 \mathrm{~cm}$

Slate chips, slate ring 
1 lump diatomaceous earth

15 Shell beads, perforated, (tiny)

$7 \quad$ Incensario sherds (Early Xolalpan flange)

\section{Early Xolalpan Burial 27}

1 Perinatal

Provenience: Site 3E:N3E4, Square W1N7 (fig. 15)

2 Green obsidian prismatic blades

\section{Early Xolalpan Burial 27 A}

1 Adult

Provenience: Site 3E:N3E4, Stratigraphic Pit 33. Fragments of bone (mandible, cranium) scattered on Floor 5 (fig. 15)

Slate, quartz fragments

Pyrite disk fragment

\section{Early Xolalpan Burial 28}

1 Female, advanced age (secondary)

Provenience: Site 3E:N3E4, Square W1S5, Shrine 3 (fig. 15)

2 Polished outcurving bowls. Diam. $13 \mathrm{~cm}$, ht. $2.5 \mathrm{~cm}$

1 Bone disk, perforated. diam. $4 \mathrm{~cm}$

$3 \quad$ Clay finger rolls. $1,1.5 \mathrm{~cm}$ long

1 Clay adorno, diamond shape

1 Obsidian projectile point

$8 \quad$ Green Obsidian prismatic blades

1 Pedernal flake 


\section{Early Xolalpan Burial 29}

1 Perinatal (secondary)

Provenience: Site 3E:N3E4, Square W1S5 (fig. 15)

$2 \quad$ Bone needles

1 Green obsidian prismatic blade

$2 \quad$ Reworked disks

Fragments of jadeite and slate

\section{Early Xolalpan Burial 32}

1 male, middle aged

Provenience: Site 3E: N3E4, Squares W1S7, A2-W1S6, E2 (fig. 15)

1 Polished outcurving bowl. Diam. at rim $14 \mathrm{~cm}$ (fragment)

1 Thin Orange bowl, bipinched and incised. Diam. at rim 12-12.5 cm

1 Fine Matte miniature bowl (fragment)

1 Orange Gloss compound silhouette jar, cream paste. Diam. at rim $10.5 \mathrm{~cm}$, base $6.5 \mathrm{~cm}$, maximum width $14 \mathrm{~cm}$

1 Shell bead, 1 Shell button

Piece of slate

\section{Early Xolalpan Offering 2}

Provenience: Site 3W:N3E4, Square W4S3, C-D 2. North of Circular Structure 9 (fig. 15)

1 Matte Incensario consisting of a flanged receptacle, a conical base, an upside down bowl, a plaque and elaborate adornos

1 Matte Incensario unflanged bowl with squarish rim, numerous parts of plaques, censer bases, adornos and chimney

\section{Early Xolalpan Offering 3}

Provenience: Site 3W:N3E4, Square W4S4, A1, Patio (fig. 15)

1 Matte Incensario with flanged censer bowl and fugitive white paint. Diam. of flange $23.7 \mathrm{~cm}$, ht. $14 \mathrm{~cm}$ 
1 Matte conical censer base with rounded base, no flange. Diam. at top $12.5 \mathrm{~cm}$, at base $21.7 \mathrm{~cm}$, ht. $9.6 \mathrm{~cm}$

1 Matte Incensario intermediate section, with rounded side-base angle. Diam. at rim $23 \mathrm{~cm}$, ht. $9 \mathrm{~cm}$

1 Matte plaque (15 fragments with geometric designs) partially reconstructable

14 Fine Matte molded adornos (square elements, nose piece, butterfly, spearpoints, 7 fan shapes, 2 disks)

$1 \quad$ Painted face mask

$1 \quad$ Fine Matte miniature bowl

\section{Early Xolalpan Offering 5}

Provenience: Site 3W:N3E4, Square W4S4, A3 (fig. 15)

Parts of Incensario

$1 \quad$ Matte chimney

2 Censer flanges

\section{Early Xolalpan Offering 7}

Provenience: Site 3E:N3E4, Square W1S7, A2. In hole above Burial 32.(fig. 15)

1 Matte Incensario base with perforation for chimney on top. Diam. at base $22 \mathrm{~cm}$, top $11.5 \mathrm{~cm}$, ht. $12 \mathrm{~cm}$

1 Matte plaques with polychrome motifs, once the frame on either side of the mask. Width $9.3 \mathrm{~cm}$

1 Matte triangular shaped plaque. Width $8.5 \mathrm{~cm}$ Irregular black parallel lines

1 Matte plumed headdress with green and yellow and white paint. Length $7.8 \mathrm{~cm}$, width $2.5 \mathrm{~cm}$, thickness $4 \mathrm{~mm}$

2 Matte fragments of headdress

$8 \quad$ Molded Matte disk adornos. Diam. 3.7 to $5.5 \mathrm{~cm}$

1 Fine Matte bird adorno

1 Matte painted face mask, and Tlaloc nosepiece 


\section{Early Xolalpan Offering 8}

Provenience: Site 3E: N3E4, Square W1S5, Shrine 3 (fig. 15)

Parts of Incensario:

2 Incensario plaques

$1 \quad$ Matte chimney

$1 \quad$ Matte censer bowl with fugitive white paint

Misc. Matte adornos. (disks, square)

\section{Early Xolalpan Offering 14}

Provenience: Site 3W:N4E4, Square W4S4, C1 (fig. 15)

Fragments of Incensario

$1 \quad$ Matte censer flange

5 Fine Matte adornos: 3 disks (diam. $5.5 \mathrm{~cm}$ ), 1 Matte green feathered piece, 1 butterfly

$1 \quad$ Matte face mask (4 frag.)

1 Matte miniature molcajete (mortar) Diam. $6 \mathrm{~cm}$, ht. $2 \mathrm{~cm}$

Plaque fragments

\section{Early Xolalpan Offering 15}

Provenience: Site 12:N4E4, Square E1S2, CD2, Circular Structure 11 (fig. 16)

1 Thin Orange ringbase bowl with worn interior. Diam. at rim $20 \mathrm{~cm}$, base $8 \mathrm{~cm}$, ht. $5 \mathrm{~cm}$

1 Polished pale brown collared bowl, compact paste. Diam. at rim $19 \mathrm{~cm}$, base $9.5 \mathrm{~cm}$, ht. $4 \mathrm{~cm}$

\section{Early Xolapan Offering 18}

Provenience: Site 3E:N3E4, Square W1S3, DE2-DE3. Circular Structure \#3, Floor 2 (fig. 15)

Parts of Incensario:

1 Matte censer flange

11 Misc. Matte censer bodies (fragments)

2 Gray Obsidian projectile points 
1 Lithic object, round

$1 \quad$ Fine Matte miniature bowl

1 Bone graver

\section{MERCHANTS' BARRIO LATE XOLALPAN BURIALS}

\section{Late Xolalpan Burial 3}

1 Adult, incinerated

Provenience: Site 3E:N3E4, Square E1N1, Adoratorio 1 (fig. 15)

1 3-Prong burner (frag. covering bones)

Partially reconstructible vessels:

2 Thin Orange cylindrical vases with hollow round supports and molded heads around basal flange: (1) diam. at rim approx. $13.5 \mathrm{~cm}$, ht. $9 \mathrm{~cm}$ (2) diam. at rim $14 \mathrm{~cm}$, ht. $9 \mathrm{~cm}$

1 Thin Orange recurved bowl with light.ly grooved parallel lines. Diam. at rim $13 \mathrm{~cm}$, ht. $5 \mathrm{~cm}$

1 Thin Orange recurved bowl (smaller than above)

2 Thin Orange ringbase bowls

1 Thin Orange jar, conical body, flaring rim. Diam. at rim $18.5 \mathrm{~cm}$; neck diam. $11 \mathrm{~cm}$, ht. $11 \mathrm{~cm}$

1 Low Polished outcurving bowl. Diam. at rim $14 \mathrm{~cm}$, ht. $4 \mathrm{~cm}$

1 Low Polished outcurving bowl. Diam. at rim $10 \mathrm{~cm}$, ht. $4 \mathrm{~cm}$

1 Thin Orange animal effigy (fragments)

1 Green stone

1 Shell necklace

Slate pieces 
Late Xolalpan Burial $10-12$

6 Individuals: 2 young males; 1 young female; 1 fetus, 2 children

Provenience: Site 3W:N3E4, Circular Structure 4, Square W3S8 (fig. 15)

1 Polished outcurving bowl, very open with stick polished interior. Diam. at rim $14.5 \mathrm{~cm}$, ht. $1.5 \mathrm{~cm}$

1 Polished outcurving bowl, very open with stick polished interior. Diam. at rim $12.5 \mathrm{~cm}$, ht. $1.2 \mathrm{~cm}$

1 Copa ware light. brown plano-relief vase with hollow cylindrical supports.

Diam. at rim $10.5 \mathrm{~cm}$, base $10 \mathrm{~cm}$, ht. $10 \mathrm{~cm}$

1 Polished Copa ware vase, plain with hollow cylindrical supports. Diam. at rim $12.5 \mathrm{~cm}$, base $11.5 \mathrm{~cm}$, ht. $10.5 \mathrm{~cm}$

\section{Late Xolalpan Burials 13a -13b (Looted)}

1 Perinatal, 1 young female

Provenience: Site 3W:N3E4, Square W2S9, Circular Structure \#4. Boot shaped shaft tomb ("Pozo tronco cónico") $2.2 \mathrm{~m}$ deep, shaft diam. $1 \mathrm{~m}$, chamber $1.5 \mathrm{~cm}$ wide (fig. 15)

Offering reconstructed from fragments:

6 Polished cylindrical vases: (1) Incised vase with round support scars. Diam. $15 \mathrm{~cm}$; (2) plain vase. Diam. $20 \mathrm{~cm}$, (3) plain vase. Diam. $22 \mathrm{~cm}$

1 Polished outcurving bowl, diam. $16 \mathrm{~cm}$, ht. $3 \mathrm{~cm}$

36 Fine Matte miniatures bowls (average diam. $10 \mathrm{~cm}$ )

1 Low Polish orange bowl. Diam. $18 \mathrm{~cm}$

1 Polished Lustrous ware black jar

$1 \quad$ Fine Paste Incised white vase

$1 \quad$ Incised and Carved Fine Paste bowl

1 Polished sieve with perforated body

2 Polychrome Maya bowls

1 Stuccoed Painted vase with cutout rectangular supports. Scroll designs in white, orange-red outlined in black. Diam. $16 \mathrm{~cm}$

$1 \quad$ Tlaloc vase

1 Copoid ware dish with nubbin. Diam. at $\operatorname{rim} 8 \mathrm{~cm}$, base $6 \mathrm{~cm}, \mathrm{ht} .3 \mathrm{~cm}$ 
$1 \quad$ Shell object

1 Puppet figurine, large

Red pigment

$\underline{\text { Late Xolalpan Burials } 15-16}$

1 Adult male

Provenience: Site 3W:N3E4, Squares W3N2-W2N2. In Platform (fig. 15)

$1 \quad$ Ceramic disk

1 Thin Orange bowl, miniature. Diam. $12 \mathrm{~cm}$, base $5 \mathrm{~cm}$

1 Polished outcurving bowl. Diam. $17 \mathrm{~cm}$

1 Low Polish outcurving bowl

$1 \quad$ Dense ware bowl

Pyrite disk (fragment)

\section{Late Xolalpan Burial 17}

1 Adult female, middle aged

Provenience: Site 3W:N3E4, Square W2N6, Adoratorio 2 (fig. 15, 19)

1 Thin Orange outcurving bowl

1 Thin Orange bowl with irregular zig-zag grafitti in interior. Diam. $25 \mathrm{~cm}$

1 Thin Orange globular jar with flat base and small flange

1 Thin Orange miniature

1 Copa ware cylindrical vase with molded supports. Diam. $17 \mathrm{~cm}$, ht. $1 \mathrm{~cm}$

1 Low Polish outcurving bowl. Diam. at rim $11 \mathrm{~cm}$, ht. $3.5 \mathrm{~cm}$

1 San Martin Orange amphora (early type) with pocked base, everted rim. Diam. at rim $10 \mathrm{~cm}$, body diam. $15 \mathrm{~cm}$, ht. approx. $25 \mathrm{~cm}$

1 Polished brown wide mouth jar with matte neck. Diam. at rim $10 \mathrm{~cm}$

$2 \quad$ Clay "finger rolls"

1 Candelero 


\section{Early or Late Xolalpan Burial 18}

1 Fetus

Provenience: Site 3W:N3E4, Square W2N6, near Adoratorio 2 (fig. 15,19)

1 Low Polish outcurving bowl. Diam. at rim $12 \mathrm{~cm}$, at base $7 \mathrm{~cm}$, ht. $3.5 \mathrm{~cm}$

\section{Early or Later Xolalpan Burial 19}

1 Adult, middle age male

Provenience: Site 3W:N3E4, Square W3S1 (fig. 15)

1 Streak Polished outcurving bowl. Diam. at rim $13 \mathrm{~cm}$

1 Fine Matte black-brown bowl, diam. $3 \mathrm{~cm}$

1 Thin Orange ringbase bowl, diam. $15 \mathrm{~cm}$

1 Clay seal with molded motif, diam. $2.2 \mathrm{~cm}$

1 Pyrite mirror with yellow substance adhering (fragment)

Piece of slate

\section{Late Xolalpan Burial 33}

1 Adult, male, middle age; 1 young adult male

Provenience: Site 9:N3E4, Square E4N9, Circular Structure \#15 (fig. 17)

1 Painted red on natural crater (diamond, circular scroll motifs). Diam. at rim $55 \mathrm{~cm}$, ht. approx. $50 \mathrm{~cm}$, wall thickness 1 to $1.3 \mathrm{~cm}$

1 Polished lid. Diam. $17 \mathrm{~cm}$

1 Polished cylindrical vase with hollow cylindrical supports incised. Diam. at rim $17 \mathrm{~cm}$

1 Polished cylindrical vase with basal bosses. Diam. at rim $13 \mathrm{~cm}$

1 Polished outcurving bowl, diam. at rim $14 \mathrm{~cm}$, ht. $8.5 \mathrm{~cm}$

2 Polished outcurving bowls with nubbin supports:

(1) diam. at rim $11.4 \mathrm{~cm}$, ht. $3.8 \mathrm{~cm}$

(2) diam. at rim $11.4 \mathrm{~cm}$, ht. $3.6 \mathrm{~cm}$

$1 \quad$ Polished recurved bowl. Diam. at rim $11.9 \mathrm{~cm}$, ht. $3.5 \mathrm{~cm}$

1 Fine Matte outcurving bowl. Diam. at rim $12 \mathrm{~cm}$, ht. $3.1 \mathrm{~cm}$

1 Copa Ware Vase with molded supports. Diam. at rim $12.3 \mathrm{~cm}$, ht. $14.4 \mathrm{~cm}$ 
1 Polished jar, pattern polished neck. Diam. at rim $16.5 \mathrm{~cm}$, ht. $16-16.5 \mathrm{~cm}$

1 Thin Orange jar with upright. rim and bosses on body. Diam. at rim $6 \mathrm{~cm}$

1 Thin Orange ring base bowl, punctate and incised. Diam. at rim $17 \mathrm{~cm}$

1 Slate disk with yellow pigment

Pieces of slate

Shell buttons

$1 \quad$ Bone needle

2 Pieces pedernal

$1 \quad$ Bird figurine head

\section{$\underline{\text { Late Xolalpan Burial } 34}$}

1 Adult, young male; 1 young adult female; 1 fetus

Provenience: Site 9:N3E4, Square E4N7 (fig. 17)

1 Thin Orange ring base bowl (fragment)

1 Gloss ware jar (fragment)

1 Fine Matte miniature

\section{$\underline{\text { Late Xolalpan Burial } 17}$}

Provenience: Site 3E:N3E4, Square W1N1, A4 . On Platform covering Circular Structure \#1 (fig. 15)

Large pieces of Incensario:

1 Late Xolalpan Matte flanged censer rim, with white paint on body ( 20 pieces)

$1 \quad$ Matte censer stands and bowls (63 pieces)

1 Matte rounded censer body with red pigment on interior

\section{Late Xolalpan- Metepec Offering 1}

Provenience: Site 3W:N3E4, Square W2S3, D2, Circular Structure \#8 (fig. 15)

1 Matte Incensario conical base with flaring sides. Diam. base $23 \mathrm{~cm}$, top $12 \mathrm{~cm}$, ht. $9.5 \mathrm{~cm}$ 
1 Matte flanged Incensario bowl with white fugitive paint. Diam. of flanged rim 24 $\mathrm{cm}$, ht. $9.4 \mathrm{~cm}$

1 Matte chimney. Ht. $23 \mathrm{~cm}$, diam. of tube $4.4 \mathrm{~cm}$

7 Fine Matte adornos ( 3 disks, 3 plumed objects, 1 spearpoint)

$1 \quad$ Fine Matte face mask (2 pieces)

1 Fine Matte plaque, complete. Length $23 \mathrm{~cm}$, ht. $12.5 \mathrm{~cm}$

1 Fine Matte plaque, incomplete. Ht. $9.6 \mathrm{~cm}$

Misc. placque fragments

UNPHASED MERCHANTS' BARRIO BURIALS

\section{Unphased Burial 1}

1 Perinatal

Provenience: Site 3E:N3E4, Square E1S2, A1 (fig. 15)

No associated offering

\section{$\underline{\text { Unphased Burial } 30}$}

1 Young adult, female, 1 fetus

Provenience: Site 3E:N3E4, Square W1S5, E1 (fig. 15)

(Fragmentary offering)

1 Coarse Matte Incensario (incomplete)

1 Polished outcurving bowl. Diam. $11 \mathrm{~cm}$

2 Candeleros: (1) plain, $8 \mathrm{~cm}$, (2) polished rim, $7 \mathrm{~cm}$

1 Thin Orange corrugated outcurving bowl with nubbins, diam. $16 \mathrm{~cm}$

1 Thin Orange miniature. Diam. ringbase $3 \mathrm{~cm}$

1 Fine Matte miniature. Diam. $2.5 \mathrm{~cm}$, ht. $1.5 \mathrm{~cm}$

1 Thin Orange reworked disk. Diam. $2 \mathrm{~cm}$

1 Burnished reworked olla disk. Diam. $2 \mathrm{~cm}$

14 Clay "finger rolls" with red and white pigment 
1 Bone needle

1 Micaceous jar, coarse paste (foreign)

1 Shell necklace (tiny beads)

1 Green stone, worked

Piece of slate

Mica flakes

\section{Unphased Burial 31}

1 Adult, middle age

Provenience: Site 3E:N3E4, Square W2S5, shallow hole (fig. 15)

1 Coarse Matte stove prong (fragment)

$1 \quad$ Fine Matte miniature (fragment)

1 Thin Orange bowl (fragment)

\section{Unphased Burial 35}

1 Adult, middle age male

Provenience: Site 12:N4E4, Square S2W3, Adoratorio 5 (fig. 16)

Pieces of shell

Charcoal

\section{Unphased Offering 4}

Provenience: Site 3W:N3E4, Square W3S3, E3, Cicular Structure \#8 (fig. 16)

2 Thin Orange ringbase bowls. Diam. at rim 22, $23 \mathrm{~cm}$

\section{Unphased Offering 9}

Provenience: Site 8:N4E4, Square W3N3, E4 (fig. 16)

1 Incensario (fragments of censer base, bowl) 


\section{Unphased Offering 10}

Provenience: Site 12:N4E4, Square W3S3, A 2-3. Within Platform (fig. 16)

1 Polished brown upright. bowl with unusually thick walls. Diam. at rim $18 \mathrm{~cm}$, base $13 \mathrm{~cm}$, ht. $7.5 \mathrm{~cm}$

1 Fine Paste White Slip Incised bowl with pie-shape cutout done after firing.

Diam. at rim $17 \mathrm{~cm}$, rounded base approx. $9 \mathrm{~cm}$, ht. $5 \mathrm{~cm}$

Unphased Offering 11

Provenience: Site 3E: N3E4, Square E1S1, E1 (fig. 15)

1 Matte Incensario, 7 fragments

1 Candelero

2 Fine Matte moldmade adornos

\section{Unphased Offering 12}

Provenience: Site 3E:N3E4, Square E1N5, Circular Structure \#12 (fig. 15)

1 Thin Orange ringbase bowl. Diam. $26 \mathrm{~cm}$

\section{Unphased Offering 16}

Provenience: Site 3W:N3E4, Square W3S3 (fig. 15)

1 Matte chimney, incensario part 
TEOTIHUACAN PROJECT 1960-1964

Instituto Nacional de Antropología e Historia

(Acosta 1964; Muller 1978)

\section{OFFERINGS: TEMPLE OF QUETZALPAPALOTL}

Early Xolalpan Offering 2 (Acosta 1964: 56, Chart p. 55)

Provenience: North Room, Patio of the Columns, below talud

$1 \quad$ Polished ("stick polished") black simple bowl (or cover?)

1 Polished black incised outcurving bowl with conical nubbins

$1 \quad$ Painted red on light brown "stick polished" recurved bowl

$1 \quad$ Painted red on light brown recurved bowl

2 Fine Matte miniature bowls (charcoal inside)

1 Fine Matte cover-plate (fragment)

6 Obsidian prismatic blades, 1 spine shaped

Early Xolalpan Offering 3

Provenience: North Room Patio of the Columns, below talud (Acosta 1964: Chart p. 55; Muller 1978, fig. 6)

1 Polished ("stick polished") black-brown outcurving bowl (charcoal inside)

$1 \quad$ Polished light brown flaring "vase" with flat bottom (frag.)

$1 \quad$ Polished black jar (frag.)

1 Copa ware copa, $\tan ($ frag.)

1 Lava Stone "flatiron" Polisher (extremely worn, covered with stucco)

$1 \quad$ Slate disk

$6 \quad$ Green Obsidian prismatic blades

$8 \quad$ Hand Bones 


\section{Late Tlamimilolpa Offering, Palacio 3}

Provenience: Palace 3 (Quetzalpapolotl Palace), North side of the substructure (Muller 1978)

1 Burnished light brown basin with three hollow supports. Diam at rim $34.5 \mathrm{~cm}$, base $32 \mathrm{~cm}$, ht $11.5 \mathrm{~cm}$, supports $4.5 \mathrm{~cm}$

1 Polished brown black outcurving bowl with incised cloud motif . MNA 1306

1 Polished incised brown black basal incurved tripod bowl, interior rim incised. MNA 1292

1 Polished outcurving bowl incised rim and cloud motif on exterior

1 Polished low cylindrical vase with conical nubbins. MNA 985

South side of Substructure:

1 Polished yellowish brown basal incurved bowl with groove incised cloud motif

(Early Tlamimilolpa form) Diam at rim $23.4 \mathrm{~cm}$, base $16.5 \mathrm{~cm}$, ht $7.5 \mathrm{~cm}$ MNA 9-4341

\section{Early Xolalpan Offering "Ofrenda Desague"}

Provenience: Palacio 3 "Ofrenda desague" (Drain Offering) (Muller 1978: 40)

1 Polished black brown outcurving bowl with flat base, with perforation in center (diam. $2 \mathrm{~cm}$ ). Diam at rim $19.5 \mathrm{~cm}$, base $12.5 \mathrm{~cm}$, ht. $4.5 \mathrm{~cm}$ MNA 9-4361 3/9

1 Thin Orange bowl. MNA 4338 8/9

1 Polished finely incised lid with plain knob. Diam. $9.5 \mathrm{~cm}$, ht. $4 \mathrm{~cm}$

\section{Metepec Offering "Ofrenda Desague"}

Provenience: Palacio 3 (Quetzalpapalotl Palace) "Ofrenda Desague" (Drain Offering) (Muller 1978: 40)

1 Polished outcurving bowl, obtuse angled with molded 5-pointed star design in interior. MNA 9-2758 
BURIALS AND OFFERINGS TEOTIHUACAN PROJECT 1960-1964

$\underline{\text { Early Tlamimilolpa Site } 57 \text { Burial 8, }}$

Fetus

Provenience: Site 57, Pit II (north of San Juan river, east of zone highway) (Muller 1978: 44-49)

1 Thin Orange ringbase bowl (MNA 2999)

1 Polished outcurving bowl

\section{Metepec Site 57 Burial 6}

Age-sex unknown

Provenience: Site 57, Stratigraphic Pit 1, layer 5 (Muller 1978: 44-49)

1 Zone Polished and incised cylindrical vase with bud-like supports. Diam. at rim $12 \mathrm{~cm}$, ht. $11.5 \mathrm{~cm}$ MNA 9-2831

2 Copa ware cylindrical vases

$1 \quad$ Matte miniature bowl

\section{$\underline{\text { Late Tlamimilolpa Offering I }}$}

Provenience: "Fosa Tepalcates" (Sherd dump), from hole in South wall (Muller 1978:44-49)

1 Polished brown black outcurving bowl with nubbin supports. Diam. at rim $17.9 \mathrm{~cm}$, base $13 \mathrm{~cm}$, ht. $6 \mathrm{~cm}$

1 Polished brown outcurving bowl with nubbin supports, postfire incised flower design on outside base. Crude potter's mark on side.Diam at rim $13.8 \mathrm{~cm}$, base $9 \mathrm{~cm}$, ht. $4.4 \mathrm{~cm}$

2 Polished tecomates

$2 \quad$ Fine Matte ollitas 
TEOTIHUACAN ARCHAEOLOGICAL PROJECT 1980-1982

Instituto Nacional de Antropología e Historia

(González y Fuentes 1982; González y Salas 1990)

Miccaotli to Metepec Phase Burials : 1980-1982 Excavations

113 Individuals: 1 Fetus, 27 infants, 5 children, 4 adolescents, 2 sub-adults ( 1 male, 1 female); 27 young adults ( 15 males, 12 females); 14 middle aged adults ( 10 males, 4 females) and 8 aged male adults (Gonzalez and Salas 1990: 163-177, Fig. 3,4)

Proveniences: Squares of Teotihuacan Map (Millon 1973) N1E2, N2E2, N3E2, N2W3, N2W6, N7W2, S3E5, S3E6 and Santa María Palapa (González and Fuentes 1982:421)

Old Temple of Quetzalcoatl, south and north passageways, North Ciudadela Palace, "Banqueta", Street of the Dead; Great Rectangle north of the Ciudadela; "Semicircular Structures" (González y Salas Fig. 1, 2, 5, 6; González y Fuentes 1982).

No data on offerings

\section{Early Xolalpan Decapitation Burials}

12 Individuals: Young male adults, 1 incineration, 1 primary, 6 decapitations, 4 secondaries: Burial in a shrine.

Provenience: Amanalco, San Francisco Mazapa (Martínez y González 1983)

(Offering subjected to extreme heat in ceremonial fire. Ceramics burnt and misshapen.)

1 Gulf Coast Lustrous ware cylindrical vase. Remainder of offering not known

1 Incensario 


\section{REFERENCES CITED}

Abbreviations:

ENAH Escuela Nacional de Antropología e Historia

IIA Instituto de Investigaciones Antropológicas

INAH Instituto Nacional de Antropología e Historia

SMA Socieded Mexicana de Antropología

UNAM Universidad Nacional Autónoma de México

Acosta, Jorge

1964 El Palacio del Quetzalpapalotl. Memorias del Instituto Nacional de Antropología e Historia X.

Acosta Saignes

1945 Los Pochteca, Ubicación de los Mercaderes en la Estructura Social Tenochca. Antropológica I, 1:9-54. ENAH

Angulo, Jorge

1987 Nuevas Consideraciones sobre los Llamados Conjuntos Departamentales Especialmente Tetitla. Teotihuacan: Nuevos Datos, Nuevas Sintesis, Nuevos Problemas. Editors, E. McClung de Tapia and E. Rattray. IIA, UNAM.

1989 Observaciones sobre el Templo de la Agricultura en Teotihuacan. In Homenaje a Roman Piña Chan, IIA, UNAM

Armillas, Pedro

1950 Teotihuacan, Tula y los Toltecas, RUNA III: 1-2, pp. 37-70. Buenos Aires.

Aveleyra Arroyo de Anda, Luis

1963 La Estela Teotihuacana de La Ventilla. Cuadernos del Museo Nacional de Antropología I

1964 Obras Selectas del Arte Prehispánico. Edición Conmemorativa de la Inauguración del Nuevo Edificio del Museo Nacional de Antropología. México.

Ball, Joseph

1983 Teotihuacan, the Maya, and Ceramic Interchange: A Contextual Perspective. In Highland-Lowland Interaction in Mesoamerica. Edited by Arthur Miller. Dumbarton Oaks Library and Collection. Washington D. C. pp. 125-145

Batres, Leopoldo

1906 Teotihuacan: Memoria Relativa a las Exploraciones en las Pirámides de Teotihuacán. Fidencio S. Soria, México. XV Congreso Internacional de Americanistas. Quebec. 
Bennyhoff, James

1964-1966 Field and laboratory Notes on Teotihuacan Burials. Teotihuacan Mapping Project Field Laboratory, Teotihuacan

Berrin, Kathleen, editor 1988 Feathered Serpents and Flowering Trees. The Fine Arts Museum of San Francisco.

Bernal, Ignacio 1963 Teotihuacan: Descubrimientos, Reconstrucciones INAH.

Blucher, Darlena

1969 Field Notes. Teotihuacan Mapping Project Excavation at Tetitla (TE 24).

1971 Late Preclassic Cultures in the Valley of Mexico: Pre-Urban Teotihuacan. Ph. D. thesis. Department of Anthropology, Brandeis University. University Microfilms.

Ann Arbor.

Cabrera, Rubén

1987 La Secuencia Arquitectónica del Edificio de Los Animales Mitológicos en Teotihuacan. In Homenaje a Román Piña Chan. IIA, UNAM

1987b Resumen y Comentarios de Los Trabajos Presentados en el Simposio por el Proyecto Arqueológico, Teotihuacan 80-82. Nuevos Datos, Nuevas Sintesis, Nuevas Problemas. Editors: E. McClung de Tapia y E. Rattray. IIA,UNAM

Cabrera, Rubén, George Cowgill, Saburo Sugiyama y Carlos Serrano

1989 El Proyecto Templo de Quetzalcoatl. Arqueología 5. Dirección de Monumentos Prehispánicos. INAH

Cabrera, Rubén, G. Cowgill and Saburo Sugiyama

1990 El Proyecto Templo de Quetzalcoatl y la Práctica a Gran Escala del Sacrificio Humano. La Epoca Clásica: Nuevos Hallazgos, Nuevas Ideas. Coordinator, Amalia Cardoz de Mendoza, INAH and Museo de Antropología

Cabrera, Rubén, Ignacio Rodríguez y Noel Morelos 1982 Memoria del Proyecto Arqueológico Teotihuacan 80-82. Colección Científica 132, INAH

Cabrera, Rubén and Enrique Soruco

1982 Pequeñas Basamentos Habitacionales en la Calle de Los Muertos. Memoria del Proyecto Arqueológico Teotihuacan 80-82. Coordinated by R. Cabrera, I. Rodríquez and N. Morelos. Colección Científica 132. INAH

Caso, Alfonso, Ignacio Bernal and Jorge Acosta

1967 La Cerámica de Monte Albán. Memorias del Instituto Nacional de Antropología e Historia 13. INAH, Mexico

Chadwick, Robert

1974 The Archaeology of a New World "Merchant" Culture. Ph. D Thesis. Tulane University. University Microfilms, Ann Arbor. 
Civera, Magalí

1983 Recuento Total y Características Generales de los Individuos Representados en el Material Oseo Proveniente del Barrio de los Comerciantes. Instituto de Investigaciones

Antropológicas, UNAM. Unpublished manuscript

1989 Los Pobladores de Barrio de Los Comerciantes, Teotihuacan. Análisis Osteológico de Sus Entierros. Instituto de Investigaciones Antropológicas, UNAM. Unpublished manuscript

Coggins, Clemency

1979 Teotihuacan at Tikal in the Early Classic Period. Actas du XLII ${ }^{e}$ Congrés International de Americanistes 8: 251-269. Paris 1979

Cook de Leonard, Carmen

1952 Notas del Interior. Tlatoani Vol.3-4: 49. Mexico

1957a Field Notes. Excavations at Ostoyahualco, Teotihuacan.

1957b Proyecto del CIAM en Teotihuacan. Excavaciones en La Plaza \#1, "Tres Palos", Teotihuacan. Boletín del Centro de Investigaciones Antropológicas de México. No.4

1957c El Origén de la Cerámica Anaranja Delgada. Masters Thesis, ENAH.

1971 Ceramics of the Classic Period in Central Mexico. Handbook of Middle American Indians. Vol. 10: 179-205. University of Texas Press.

Cowgill, George

1981 Computer Maps. Brandeis University. Unpublished

1981 Chingú y la Expansión Teotihuacana. Interacción Cultural en México Central. Editadp por E. Rattray, J. Litvak y C. Diaz O. IIA, UNAM

Dozal, Pedro J.

1925 Descubrimientos Arqueológicos en el Templo de Quetzalcoatl (Teotihuacan). Anales del Museo Nacional de Arqueología, Historia y Etnografía. México. pp. 216-219. Gamio, Manuel

1922 La Población del Valle de Teotihuacan. Vol. I, 1. Secretaría de Agricultura y Fomento, Dirección de Antropología, México.

García Cook, Angel, Martha Arias M. G. and Rafael Abascal M.

1976 Una Tumba de la Fase Tenenyecac en Tlaxcala, Mexico. In Suplemento Comunicaciones 3, Vol. I. pp. 13-28. Fundación Alemana para la Investigación Científica. Puebla.

González, Luis Alfonso y David Fuentes

1982 Informe de Labores Realizadas por la Sección de Antropología Física en el Proyecto Arqueológico Teotihuacan. En Cabrera, et al. Memoria del Proyecto Arqueológico Teotihuacan 80-82. Colección Científica 132, Vol. I. INAH. 
González, Luis Alfonso y María Elena Salas Cuesta

1990 Nuevas Perspectivas de Interpretación que Proporcionan Los Entierros del Centro Politico-Religioso de Teotihuacan. In La Epoca Clásica. Nuevos Hallazgos, Nuevas Ideas. Coordinado por Amalia Cardoz. Museo Nacional de Antropología e Instituto Nacional de Antropología e Historia.

Gowlett, J., R. Hedges, I.Law and C. Perry

1987 Radiocarbon Dates from the Oxford AMS System: Archaeometry Datelist 5. Archaeometry 29,1. Great Britain.

Harbottle, Garman and Edward Sayre

1977 Neutron Activation Analysis: Teotihuacan Trade Ceramics. XV Mesa Redonda, Vol III, SMA

Heyden, Doris

1975 An Interpretation of the Cave Underneath the Pyramid of the Sun in Teotihuacan, Mexico. American Antiquity 40: 131-147.

Iceland, Harry

1989 The Stone Artifacts of the Merchants' Barrio, Teotihuacan. Masters Thesis. University of Texas at San Antonio.

Jarquín P. Ana y Enrique Martínez V.

1982 Exploración en el Lado Este de la Ciudadela : Estructuras 1G, 1R, 1Q, 1P. En Memoria del Proyecto Arqueológico Teotihuacan 80-82. Coordinadores, R. Cabrera, I. Rodríquez y N. Morelos. Colección Científica 132, INAH.

Laporte, Juan Pedro

1987 El "Talud-Tablero" en Tikal, Peten: Nuevas Datos. Homenaje a Román Piña Chan. IIA, UNAM. pp 265-310.

Linné, Sigvald

1934 Archaeological Researches at Teotihuacan, Mexico. Ethnographical Museum of Sweden, n.s., Pub.1. Stockholm

1942 Mexican Highland Cultures: Archaeological Researches at Teotihuacan, Calpulalpan, and Chalchicomula in 1934-1935. Ethnographical Museum of Sweden, n.s. Pub. 7, Stockholm

1956 Radiocarbon Dates at Teotihuacan. Ethnos 3-4. Stockholm, Sweden

Lothrop, S. F.

1959 Pre-Columbian Art. The Robert Bliss Woods Collection. Second edition. Garden City Books. Phaidon Publishers. New York.

Manzanilla, Linda

1985 El Sitio de Cuanalan en el Marco de Los Comunidades Pre-Urbanas del Valle de Teotihuacan. Mesoámerica y el Centro de México. Compilado por J.Monjaras, R. Brambila and E.

Pérez-Rocha. INAH, pp. 133-178. 
Martínez, Enrique y Luis González M.

1983 Una Estructura Funeraria Teotihuacana. Trabajo presentado en la XVII Mesa Redonda de la SMA. Taxco, Gro.

Marquina, Ignacio

1964 Arquitectura Prehispánica. Memorias INAH 1. México.

Millon, Clara

1972 The History of Mural Art at Teotihuacan. Teotihuacan, XI Mesa Redonda. SMA.

Millon, René

1957 New Data on Teotihuacan. Boletín del Centro de Investigaciones Antropológicas de México 4: $12-17$.

1960 The Beginnings of Teotihuacan. American Antiquity 26:1, pp. 1-10.

1967 Urna de Monte Albán IIIA Encontrada en Teotihuacan. Boletín del Instituto Nacional de Antropología e Historia 29:42-44

1973 Urbanization at Teotihuacan, Mexico. Vol. 1. The Teotihuacan Map. Part 1: Text. University of Texas Press. Austin.

1976 Social Relations in Ancient Teotihuacan. In The Valley of Mexico: Studies in Prehispanic Ecology and Society. Editor, Eric Wolf. University of New Mexico Press. pp. 205-248.

1981 Teotihuacan: City, State and Civilization. In Supplement to the Handbook of Middle American Indians Vol. I. Archaeology, editor, J. Sabloff, pp 198-243. University of Texas Press, Austin.

Millon, René and James Bennyhoff

1961 A Long Architectural Sequence at Teotihuacan. American Antiquity 26:4, pp. 516-523.

Millon, René, Bruce Drewitt and James A. Bennyhoff

1965 The Pyramid of the Sun at Teotihuacan: 1959 Investigations. Transactions of the American Philosophical Society, n.s., 55:6. Philadelphia.

Millon, René, Bruce Drewitt and George Cowgill

1973 Urbanization at Teotihuacan. The Teotihuacan Map. Vol. 1, Part 2. University of Texas Press. Austin.

Moore, Frank

1966 An Excavation at Tetitla, Teotihuacan. Mesoamerican Notes 7-8. University of the Americas. Mexico.

Morelos, Noel

1985 Proceso de Producción de Espacios y Estructuras en Teotihuacan. Conjunto Plaza Oeste y Complejo Calle de Los Muertos. Tesis de Licenciatura, ENAH.

Muller, Florencia

1959 La Cala X de Yayahuala, Teotihuacan. Informe al INAH. Unpublished Ms. 
Muñera, Luis Carlos Bermúdez

1985 Un Taller de Cerámica Ritual en la Ciudadela, Teotihuacan. Tesis de Licenciatura. ENAH.

Nicholson, Henry B. (assembler)

1959 Notes and News: Middle America. American Antiquity 25:2. pp. 305-309.

Noguera, Eduardo

1939 Excavations in Cuicuilco. Contribution, XXVII International Congress of Americanists. México D. F.

1955 Extraordinario Hallazgo en Teotihuacan. El México Antiguo 8: 43-46. Sociedad Alemana Mexicanista.

1961 Exploraciones en Yayahuala, Teotihuacan. Boletín del Instituto Nacional de Antropología e Historia. México.

Paddock, John, editor

1966 Mesoamerican Notes, University of the Americas, Mexico

1983 The Oaxaca Barrio at Teotihuacan. In The Cloud People. Editors, K. Flannery and J. Marcus. Academic Press. First presented at the School of American Research, Santa Fe, 1976).

Piña Chan, Román

1963 Excavaciones en el Rancho "La Ventilla". In Teotihuacan: Descubrimientos, Reconstrucciones. INAH. pp. 5-52.

Rattray, Evelyn

1968 A Tzacualli Burial from Pueblo Perdido. American Antiquity 33:1, pp. 103-105.

1969 Field Notes on the Tetitla Excavations. Teotihuacan Mapping Project, Test Excavation 24. Unpublished.

1973 The Teotihuacan Ceramic Chronology: Early Tzacualli to Early Tlamimilolpa Phases. Ph. D. dissertation. University of Missouri-Columbia. University Microfilms, Ann Arbor.

1977 Los Contactos entre Teotihuacan y Veracruz. Los Procesos de Cambio, XV Mesa Redonda II: 301-311 SMA

1978 Los Entierros de Teotihuacan. Informe sobre Los Entierros de Teotihuacan Presentado al Museo Nacional de Antropología. IIA, UNAM

1979 The Oaxaca-Teotihuacan Interaction. Instituto de Investigaciones Antropólogicas, UNAM. Unpublished manuscript.

1981 The Teotihuacan Ceramic Chronology: Early Tzacualli to Metepec Phases. IIA, UNAM. Manuscript on file.

1983 Informe al INAH de Los Analisis de Materiales Procedentes de Las Excavaciones en Tlajinga 33, Teotihuacan. Instituto de Investigaciones Antropológicas, UNAM.

1984 Primer Informe a INAH. Excavaciones en el Barrio de los Comerciantes, Teotihuacan. IIA, UNAM. 
1985 Costumbres Funerarias en el Barrio de Los Comerciantes, Teotihuacan. Presented in the XVIII Round Table. SMA. Queretaro, Qto. (In press)

1986 The Foreign Ceramics of Teotihuacan from Oaxaca, Puebla, the Gulf Coast and Maya Regions. Instituto de Investigaciones Antropológicas, UNAM. Ms on File.

1987a Los Barrios Foraneos de Teotihuacan. In Teotihuacan: Nuevos Datos, Nuevos Síntesis, Nuevos Problemas. Edited by E. McClung de Tapia and E. Rattray. IIA, UNAM

1987b Informe Final. Excavaciones en el Barrio de los Comerciantes, Teotihuacan. Temporadas 1983, 1984, 1985. IIA, UNAM.

1988 Un Taller de Cerámica Anaranjado San Martin en Teotihuacan. In Ensayos de Alfarería Prehispánica Histórica de Mesoamérica. Editors, Mari Carmen Serra Puche y Carlos Navarrete. Instituto de Investigaciones Antropológicas, UNAM.

1989 El Barrio de Los Comerciantes y El Conjunto Tlamimilolpa: Un estudio Comparativo. Arqueología 5 . Edited by G. Mastache. INAH.

1991 Evidencias de un Grupo Etnico de la Costa del Golfo en Teotihuacan. Paper presented in the Conference "Balance y Perspectiva de la Antropología en Veracruz",1987. (In Press).

Rattray, Evelyn and María Elena Ruiz

1980 Interpretaciones Culturales de La Ventilla, Teotihuacan. Anales de Antropología XVII. IIA, UNAM. pp. 105-114.

Rubín de la Borbolla, Daniel F.

1947 Teotihuacan: Ofrendas de los Templos de Quetzalcoatl. Anales del INAH. Tomo II. 1941-1946: 61-72.

Sánchez, Jesús

1982 El Conjunto Noroeste del Río San Juan. In Cabrera et al. Memoria del Proyecto Arqueológico Teotihuacan 80-82. Coordinado por R. Cabrera, I. Rodríquez y N. Morelos. Colección Científica 132, Vol. I. INAH.

Sanders, William, Rebecca Storey and Randolph Widmer

1982 Tlajinga 33: An Apartment Compound of the Pre-Columbian City of Teotihuacan. Report to the National Science Foundation. Department of Anthropology. Pennsylvania State.

Sayre, Edward V.and Garman Harbottle

1979 The Analysis by Neutron Activation of Archaeological Ceramics Related to Teotihuacan: Local Wares and Trade Sherds. Manuscript.

Sempowski, Martha

1987 Differential Mortuary Treatment: Its Implications for Social Status at Three Residential Compounds in Teotihuacan, Mexico. Teotihuacan: Nuevos Datos, Nuevas Sintesis, Nuevas Problemas. Editors, E. McClung de Tapia and E. Rattray. pp 115-131. IIA, UNAM

Schavelson, 1983 Cuicuilco. Fondo de Cultura Económica. 
Séjourné, Laurette

1959 Un Palacio en La Ciudad se Los Dioses. Exploraciones en Teotihuacan 1955-1958. INAH

1963 La Cerámica de Teotihuacan. Cuadernos Americanos. Año XXII, Vol. CXXVIII, México. pp. 33-181.

1966a Arqueología de Teotihuacan. La Cerámica. Fondo de Cultura Económica.

1966b_El Lenguaje de las Formas en Teotihuacan.

1966c Architectura y Pintura en Teotihuacan. Siglo Veintiuno Editores S.A.

Serrano, Carlos y Zaid Lagunas

1975 Sistema de Enterramiento y Notas sobre el Material Osteológico de La Ventilla Teotihuacán, México. Anales del INAH (1972-1973).

Schele, Linda and David Friedel

1990 A Forest of Kings. William Morrow and Co. Inc.

Smith, Robert Eliot

1987 A Ceramic Sequence from the Pyramid of the Sun Teotihuacan, Mexico. Papers of the Peabody Museum of Archaeology and Ethnology. Vol. 75. Harvard University. Cambridge.

Spence, Michael

1971 Skeletal Morphology and Social Organization in Teotihuacan, Mexico. Ph. D. dissertation. Southern Illinois University. University Microfilms, Ann Arbor.

1974 Residential Practices and the Distribution of Skeletal Traits in Teotihuacan, Mexico. Man 9: 262-273.

1976 Human Skeletal Material from the Oaxaca Barrio. In Archaeological Frontiers: Papers on New World High Cultures in honor of J. Charles Kelley. Editor, R. Pickering. Southern Illinois University. University Museum Studies 4.

1979 The Human Skeletons of Teotihuacan. The University of Western Ontario. Unpublished manuscript.

1988 Recent Excavations in Tlailotlacan, the "Barrio Oaxaqueño" of Teotihuacan. University of Western Ontario. Unpublished manuscript.

1989 Excavaciones Recientes en Tlailotlacan, El Barrio Oaxaqueño de Teotihuacan. Arqueología 5: 81-104. Edited by G. Mastache. INAH

1990 Informe de Los Análisis Tecnicos de la Segunda Temporada de Excavaciones en Tlailotlacan, Teotihuacan. Report to INAH. University of Western Ontario, Canada

1982 The Human Skeletons of Teotihuacan. Ph. d Dissertation. University of Southern Illinois.

Starbuck, David

1973 Field Notes, Yayahuala, Teotihuacan Excavations. Teotihuacan Mapping Project, Test Excavation 26. 
Storey, Rebecca

1985 An Estimate of Mortality in a Pre-Columbian Urban Population. American Anthropologist 87, pp 519-535.

1987 A First Look at the Paleodemography of the Ancient City of Teotihuacan. In Teotihuacan: Nuevos Datos, Nuevas Sintesis, Nuevos Problemas. Editors, E McClung de Tapia and E. Rattray. IIA, UNAM.

Storey, Rebecca and Randolph Widmer

1989 Household and Community, Structure of a Teotihuacan Apartment Compound S3W1:33 of the Tlajinga Barrio. Households and Communities. Chacmool, the Archaeological Association of the University of Calgary.

Stresser-Pean, Guy

1977 San Antonio Nogalar. Etudes Mesoamericaines, Vol. III. Mission Arqueologique et Ethnologique Francaise Au Mexique. México

Stuiver, E.S. Deever and L.J. Gralenski

1960 Yale Natural Radiocarbon Measurements V. American Journal of Science, Radio Carbon Supplement 2: 49-61.

Sugiyama, Saburo

1986 Recent Discoveries of Burials at the Temple of Quetzalcoatl and Their Significance. Paper presented at the 51st. Annual Meeting of the Society for American Archaeology. New Orleans, Louisiana. (Attached Chart dated 1985)

1989 Burials Dedicated to the Old Temple of Quetzalcoatl at Teotihuacan, Mexico. American Antiquity 54:1, pp 85-106

Vaillant, George

1941 The Aztecs of Mexico. Doubleday, New York.

Vidarte, Juan

1964 Exploraciones Arqueológicas en el Rancho "La Ventilla". Informe al INAH del Proyecto Teotihuacan. INAH.

Wallrath, Mathew

1966 The Calle de Los Muertos Complex: Teotihuacan: XI Mesa Redonda. SMA

Weaver, Muriel Porter

1981 The Aztecs, Maya and Their Predecessors. Academic Press (second edition).

Widmer, Randolph J.

1987a The Evolution of Form and Function in a Teotihuacan Apartment Compound: The Case of Tlajinga 33. In Teotihuacan. Nuevos Datos, Nuevas Síntesis, Nuevos Problemas. Editors, E. McClung de Tapia and E. Rattray. IIA, UNAM.

1987b Production and Economic Distribution of Craft Items at Teotihuacan: Inference from Tlajinga 33 and Maquixco Bajo. Presented at the 51st. Annual Meeting of the Society for American Archaeology, New Orleans. 
Widmer, Randolph and James Sheehy

1990 Archaeological Implications of Architectural Changes in a Modern Potting Compound in Teotihuacan, Mexico. Paper presented at the Society for American Archaeology Meetings. Las Vegas, Nevada. 
APPENDIX: TABLES 


\section{APPENDIX}

Table 1. List of Teotihuacan Burials

Ostoyahualco Burials (Cook de Leonard 1957a)

\begin{tabular}{|c|c|c|c|c|c|}
\hline Field No. Burial & Age & Sex & Type & $\begin{array}{l}\text { Location } \\
\text { (Site 1-D:N5W2), Fig. } 1\end{array}$ & Phase \\
\hline OS 1 & Adult & 1 Male & & Platform B, tunnel & Early Tzacualli \\
\hline OS 2 & Adult & & & Platform B, tunnel & Early Tzacualli \\
\hline OS 3 & & & & Platform B, tunnel & Early Tzacualli \\
\hline OS 4 & & & & Platform B, tunnel & Early Tzacualli \\
\hline OS 5 & & & & Platform B, tunnel & Early Tzacualli \\
\hline OS 6 & Adult & & Primary & Platform B, tunnel & Early Tzacualli \\
\hline OS 7 & & & & Platform B, tunnel & Early Tzacualli \\
\hline OS $8-8 a$ & Adult & & & Platform B, tunnel & Early Tzacualli \\
\hline OS 9 & & & Primary & Platform B, tunnel & Early Tzacualli \\
\hline OS 10 & Adult & & Primary & Platform B, tunnel & Early Tzacualli \\
\hline OS 11 & 2 adults & & $\begin{array}{l}1 \text { Secondary, } \\
1 \text { Primary }\end{array}$ & Platform B, tunnel & Early Tzacualli \\
\hline
\end{tabular}

Pueblo Perdido Burial (Rattray 1968, Plate I)

PP 1

Adult

Primary Under stone platform

Early Tzacualli

Ciudadela: Temple of Quetzalcoatl Burials (Sugiyama 1989)

\begin{tabular}{|c|c|c|c|c|c|}
\hline Field No. Burial & Age & Sex & Type & Location & Phase \\
\hline Q I & $\begin{array}{l}1 \text { Individual } \\
\text { I Individual }\end{array}$ & $\begin{array}{l}\text { East side } \\
\text { West side }\end{array}$ & & $\begin{array}{l}\text { Upper part of, } \\
\text { Old Temple (Gamio 1922) } \\
\text { (Sugiyama 1989, fig. 2) }\end{array}$ & $\begin{array}{l}\text { Miccaotli-Early } \\
\text { Tlamimilolpa }\end{array}$ \\
\hline Q II & 2 Individuals & & & $\begin{array}{l}\text { Upper part of } \\
\text { Old Temple (Gamio 1922), }\end{array}$ & $\begin{array}{l}\text { Miccaotli-Early } \\
\text { Tlamimilolpa }\end{array}$ \\
\hline Q III & 2 Individuals & & & $\begin{array}{l}\text { Upper part of } \\
\text { Old Temple (Gamio 1922), }\end{array}$ & $\begin{array}{l}\text { Miccaotli-Early } \\
\text { Tlamimilolpa }\end{array}$ \\
\hline Q 203 & Young Adult & Male & Primary & $\begin{array}{l}\text { South Side, } \\
\text { Old Temple }\end{array}$ & $\begin{array}{l}\text { Miccaotli-Early } \\
\text { Tlamimilolpa }\end{array}$ \\
\hline Q 190 & $\begin{array}{l}7 \text { Sub-Adults, } \\
5 \text { young adults, } \\
6 \text { mature adults }\end{array}$ & 18 Males & Primary & $\begin{array}{l}\text { South Side, } \\
\text { Old Temple }\end{array}$ & $\begin{array}{l}\text { Miccaotli-Early } \\
\text { Tlamimilolpa }\end{array}$ \\
\hline Q 153 & Young Adult & Female & Primary & $\begin{array}{l}\text { South Side, } \\
\text { Old Temple }\end{array}$ & $\begin{array}{l}\text { Miccaotli-Early } \\
\text { Tlamimilolpa }\end{array}$ \\
\hline
\end{tabular}


Tlamimilolpa Compound Burials (Linné 1942)

\begin{tabular}{|c|c|c|c|c|c|}
\hline Field No. Burial & Age & Sex & Type & Location (fig. 23, 24) & Phase \\
\hline TL 1 & Adult & & Cremation & Room 16, Stage 3 & Late Tlamimilolpa \\
\hline TL 2 & Young Adult & & & Room 22, Stage 2 & Metepec \\
\hline TL 3 & Undetermined & & & Room 91 & Unphased \\
\hline TL 4 & Adult & Male & & Room 1, Stage & Late Xolalpan \\
\hline TL 5 & Adult & Male & & Room 38, Stage II & Late Tlamimilolpa \\
\hline TL 6 & Perinatal & & & Room 109 & Unphased \\
\hline TL 7 & Perinatal & & & Room 107 & Late Tlamimilolpa \\
\hline TL 8 & Perinatal & & & Room 96 & Unphased \\
\hline TL 9 & Perinatal & & & Room 10, Stage III & Early Xolalpan \\
\hline TL 10 & Perinatal & & & Room 10, Stage III & Early Xolalpan \\
\hline TL 11 & Perinatal & & & Room 50, Stage III & Early Xolalpan \\
\hline TL 12 & Perinatal & & & Room 49, Stage III & Unphased \\
\hline TL 13 & Aged individual & & & $\begin{array}{l}\text { Room 6, belowfloor } \\
\text { (excavated by Sr. Olivo, } \\
\text { proprietor) }\end{array}$ & Late Xolalpan \\
\hline
\end{tabular}

1983 Tlamimilolpa Burials (Rattray 1984, 1989)

$\begin{array}{llll}\text { TL 1-'83 } & \text { Adult } & \text { Cremation } & \text { Room 56 NE corner (fig. 24)Early Xolalpan } \\ \text { TL 2-'83 } & \text { Adult } & \text { Room 15 Looter's Pit } & \text { Early Xolalpan } \\ \text { TL 3-'83 } & \text { Perinatal } & \text { Room 15 } & \text { Late Xolalpan } \\ \text { TL 4-'83 } & \text { Perinatal } & \text { Room 15 } & \text { Late Xolalpan } \\ \text { TL 5-'83 } & \text { Perinatal } & \text { Room 15 } & \text { Late Xolalpan }\end{array}$

Xolalpan Compound (Linné 1934)

\begin{tabular}{|c|c|c|c|c|c|}
\hline Field No. Burial & Age & Sex & Type & Location (Fig. 30) & Phase \\
\hline Xo 1 & Adult, advanced & & & Room VII, tomb-like & Early Xolalpan \\
\hline Xo 2 & Adult & & & Room XV & Early Xolalpan \\
\hline Xo 3 & & & Possible cremation & Room XVI, SE corner & Late Xolalpan \\
\hline Xo 4 & & & & Room VII, outside east wall & Late Xolalpan \\
\hline Xo 5 & Adult & Male & & Room II, below floor & $\begin{array}{l}\text { Late Xolalpan- } \\
\text { Metepec }\end{array}$ \\
\hline Xo 6 & Perinatal & & & Room 2, east wall & $\begin{array}{l}\text { Late Xolalpan- } \\
\text { Metepec }\end{array}$ \\
\hline Xo 7 & Perinatal & & & Room 2, east wall & $\begin{array}{l}\text { Late Xolalpan- } \\
\text { Metepec }\end{array}$ \\
\hline
\end{tabular}


"Extraordinary Find" (Noguera 1955)

$\begin{array}{lll}\text { Ex } 1 & \text { Child } & \text { East of Street of Dead, } \\ \text { North of San Juan River } & \text { Late } & \text { Tlamimilolpa }\end{array}$

La Ventilla A, Systems I, II, III

\begin{tabular}{|c|c|c|c|c|c|}
\hline Field No. Burial & Age & Sex & Type & Location & Phase \\
\hline "Ball Court Marker' & Adult & & & System 1, Altar & $\begin{array}{l}\text { Early } \\
\text { Tlamimilolpa }\end{array}$ \\
\hline LVA 1 & & & & System 1, Patio 2 & $\begin{array}{l}\text { Late } \\
\text { Tlamimilolpa }\end{array}$ \\
\hline LVA 2 & & & & System 1, Altar & $\begin{array}{l}\text { Late } \\
\text { Tlamimilolpa }\end{array}$ \\
\hline LVA 3 & & & & System 1, Patio 2 & $\begin{array}{l}\text { Late } \\
\text { Tlamimilolpa }\end{array}$ \\
\hline LVA 4 & & & & System 1, Patio 2, Room 10 & $\begin{array}{l}\text { Late } \\
\text { Tlamimilolpa }\end{array}$ \\
\hline LVA 1A & Adult & & & System III, Temple, Room 5 & Early Xolalpan \\
\hline LVA $1 \mathrm{~B}$ & Child & & & & \\
\hline LVA $1 \mathrm{C}$ & Adult & & & System III, Room 6 & Early Xolalpan \\
\hline LVA $1 \mathrm{D}$ & 2 Adults & & & System III, Room 12 & Early Xolalpan \\
\hline LVA 2 & & & & System III, Room 5 & Early Xolalpan \\
\hline LVA 3 & & & & System III, Room 5 & Early Xolalpan \\
\hline LVA 4 & & & & System III, Room 5 & Early Xolalpan \\
\hline LVA 5 & & & & System III, Room 5 & Early Xolalpan \\
\hline
\end{tabular}

La Ventilla B Burials (Serrano and Lagunas 1975, Table 1;

Vidarte 1964; Phases, E. Rattray)

\begin{tabular}{llllll} 
Field No. Burial & Age & Sex & Type & Location in compound (fig. 6) & Phase \\
\hline LVB 1 & Adult & & Primary & Patio IS, R4 & Unphased \\
LVB 2 & Adult & Female & Primary & South wall, R1 & Early Xolalpan \\
LVB 3 & Adult & Female & Primary & Patio 5, "large pit" & $\begin{array}{l}\text { Late } \\
\text { Tlamimilolpa }\end{array}$ \\
LVB 4 & & & & Unphased \\
LVB 5 & Adult & Female & Primary & Patio 5, "large pit" & Unphased \\
LVB 6 & Adult & Female & Primary & Patio 1 S, R7 & Metepec \\
LVB 7 & Adult & Female & Primary & Patio 1 W, Room 13 & Metepec \\
LVB 8 & Adult & Male(?) & Primary & Patio 1 W, Room 13 & Metepec \\
LVB 9 & Adult & Female & Primary & Patio 1 W, Room 13 & Metepec \\
LVB 10 & Youth & & Primary & Patio 1 S, Room 7 & Late \\
& Adult & Male & Primary & Patio 5, "large pit" & Tlamimilolpa
\end{tabular}




\begin{tabular}{|c|c|c|c|c|c|}
\hline Field No. Burial & Age & Sex & Type & Location in compound & Phase \\
\hline LVB 11 & Adult & Female & Primary & Patio 5 S, Room 1 & Early Xolalpan \\
\hline LVB 12 & Infant & & Primary & Patio 1 S, Room 1 & $\begin{array}{l}\text { Late } \\
\text { Tlamimilolpa }\end{array}$ \\
\hline LVB 13 & Adult & Female & Primary & Patio 5 & $\begin{array}{l}\text { Early } \\
\text { Tlamimilolpa }\end{array}$ \\
\hline LVB 14 & Adult & Female & Primary & Patio $1 \mathrm{~S}, \mathrm{R} 4$ & Unphased \\
\hline LVB 15 & Adult & Male & Primary & Patio $1 \mathrm{~S}, \mathrm{R} 4$ & Unphased \\
\hline LVB 16 & Adult & Female & Primary & Patio 5 "large pit & $\begin{array}{l}\text { Early } \\
\text { Tlamimilolpa }\end{array}$ \\
\hline LVB 17 & Adult & Female & Primary & Patio, R 2 & Late Xolalpan \\
\hline LVB 18 & Adult & Male & Secondary & Patio 5, "large pit" & Unphased \\
\hline LVB 19 & Adult & Male & Cremation & Patio $10 \mathrm{~S}$ & Late Xolalpan \\
\hline LVB 20 & Adult & Male & Primary & Adobe Room & Unphased \\
\hline LVB 21 & Adult & Male & Primary & Patio 5 "large pit" & $\begin{array}{l}\text { Early } \\
\text { Tlamimilolpa }\end{array}$ \\
\hline LVB 22 & Adult & Female & Primary & Patio $1 \mathrm{~S}, \mathrm{R} 4$ & Unphased \\
\hline LVB 23 & Youth & & Primary & Patio 7 W, R3 & Unphased \\
\hline LVB 24 & Adult & & Secondary & Patio $1 \mathrm{~S}, \mathrm{R} 4$ & Late Xolalpan \\
\hline LVB 25 & Infant & & Primary & Patio $5 \mathrm{~S}, \mathrm{R} 1$ & Unphased \\
\hline LVB 26-27 & Adult & 1 Male, 1 Female & Secondary & Patio $6 \mathrm{~S}, \mathrm{R} 1$ & Unphased \\
\hline LVB 28 & Adult & Female & Primary & Adobe Room & \\
\hline LVB 29 & Adult & Male & Primary & Patio $1 \mathrm{~S}, \mathrm{R} 4$ & Unphased \\
\hline LVB 30 & Infant & & Primary & Patio 5 S, R1 & Unphased \\
\hline LVB 31 & Adult & Male & Primary & Patio 7 S, Room 3 & Early Xolapan \\
\hline LVB 32 & Adult & Male & Secondary & Patio 7 S, Room 3 & Early Xolapan \\
\hline LVB 33 & Adult & Female & Primary & Adobe Room 2 & Unphased \\
\hline LVB 34 & Adult & Male & Cremation & Patio $6 \mathrm{~S}, \mathrm{R} 1$ & Metepec \\
\hline LVB 35 & Adult & Male & Primary & Patio $1 \mathrm{~W}, \mathrm{R}$ Al & Late Xolalpan \\
\hline LVB 36 & Adult & Male & Primary & Patio $1 \mathrm{~W}, \mathrm{R} 15$ & Late Xolalpan \\
\hline LVB 37 & Adult & Male & Primary & Patio $1 \mathrm{~W}, \mathrm{R} 15$ & $\begin{array}{l}\text { Late } \\
\text { Tlamimilolpa }\end{array}$ \\
\hline LVB 38 & Adult Female & & Primary & Patio $1 \mathrm{~W}, \mathrm{R} 15$ & $\begin{array}{l}\text { Late } \\
\text { Tlamimilolpa }\end{array}$ \\
\hline LVB 39 & Infant & Female & Primary & Patio $1 \mathrm{~W}, \mathrm{R}$ Al & Unphased \\
\hline LVB 40 & Adult & Female & Primary & Patio $1 \mathrm{~W}, \mathrm{R}$ Al & Unphased \\
\hline LVB 41 & Adult & Male? & Primary & Adobe Room & $\begin{array}{l}\text { Late } \\
\text { Tlamimilolpa }\end{array}$ \\
\hline LVB 42 & Adult & Male & Primary & Adobe Room & $\begin{array}{l}\text { Late } \\
\text { Tlamimilolpa }\end{array}$ \\
\hline LVB 43 & Adult & Female & Primary & Adobe Room & Unphased \\
\hline LVB 44 & Adult & & Primary & Adobe Room & Unphased \\
\hline LVB 45 & Adult & Female & Primary & Patio IW, R12 & Unphased \\
\hline LVB 46 & Adult & Female & Primary & Patio $1 \mathrm{~W}, \mathrm{R}$ A1 & Unphased \\
\hline
\end{tabular}




\begin{tabular}{|c|c|c|c|c|c|}
\hline Field No. Burial & Age & Sex & Type & Location in compound & Phase \\
\hline LVB 47 & Adult & Female & Primary & Patio 1W, R13 & Unphased \\
\hline LVB 48 & Adult & Female & Primary & Patio 1S, R6 & Unphased \\
\hline LVB 49 & Adult & Female and Male & Secondary & Patio $1 \mathrm{~W}, \mathrm{R}$ Al & Early Xolalpan \\
\hline LVB 50 & Adult & Female & Primary & Patio 1W, R A1 & Unphased \\
\hline LVB 51 & Infant & Female & Secondary & Patio 1 & Unphased \\
\hline LVB 52 & Adult & Male & Primary & Patio 1S, R4 & Unphased \\
\hline LVB 53 & Adult & Female & Primary & Patio 5-N, R1 & Unphased \\
\hline LVB 54 & Infant & & Primary & Patio 5-N, R1 & Unphased \\
\hline LVB 55 & Adult & Male & Primary & "Wall E" & Unphased \\
\hline LVB 56 & Adult & $?$ & Secondary & Patio 1 & Unphased \\
\hline LVB 57 & Infant & & Primary & Patio 1W, R6 & Unphased \\
\hline LVB 58 & Adult & Male & Primary & Altar III R & Late Xolalpan \\
\hline LVB 59 & Youth & Male & Secondary & Altar III R & Late Xolalpan \\
\hline LVB 60 & Youth & Female & Primary & Altar III R & $\begin{array}{l}\text { Early } \\
\text { Tlamimilolpa }\end{array}$ \\
\hline LVB 61 & Infant & & Primary & Altar III R & $\begin{array}{l}\text { Early } \\
\text { Tlamimilolpa }\end{array}$ \\
\hline LVB 62 & Infant & & Secondary & Altar III R & $\begin{array}{l}\text { Early } \\
\text { Tlamimilolpa }\end{array}$ \\
\hline LVB 63 & Adult & Female & Primary & Patio $1 \mathrm{~W}, \mathrm{R}$ Al & Unphased \\
\hline LVB 64 & Adult & Male & Primary & Patio IW, R Al & Unphased \\
\hline LVB 65 & Youth & Male & Primary & Patio 1W, Room 1 & Metepec \\
\hline LVB 66 & Adult & Male & Primary & Patio 1E, R1 & $\begin{array}{l}\text { Late } \\
\text { Tlamimilolpa }\end{array}$ \\
\hline LVB 67 & Youth & & Secondary & Adobe R2 & Unphased \\
\hline LVB 68 & Adult & Male & Secondary & Patio 1E, R1 & Unphased \\
\hline LVB 69 & Adult & Male & Secondary & Patio 1E, R-Al & Unphased \\
\hline LVB 71 & Youth & & Secondary & Patio $1 \mathrm{E}, \mathrm{R}-\mathrm{Al}$ & $\begin{array}{l}\text { Late } \\
\text { Tlamimilolpa }\end{array}$ \\
\hline LVB 72 & Adult & Female & Secondary & Patio 1E, R-A1 & $\begin{array}{l}\text { Early } \\
\text { Tlamimilolpa }\end{array}$ \\
\hline LVB 73A & Adult & Female & Primary & Adobe S, R3 & $\begin{array}{l}\text { Early } \\
\text { Tlamimilolpa }\end{array}$ \\
\hline LVB 73B & Adult & Female & Secondary & Adobe S, R3 & $\begin{array}{l}\text { Early } \\
\text { Tlamimilolpa }\end{array}$ \\
\hline LVB 74 & Adult & Female & Primary & Adobe $\mathrm{S}, \mathrm{R} 3$ & $\begin{array}{l}\text { Early } \\
\text { Tlamimilolpa }\end{array}$ \\
\hline LVB 75A & Adult & Male & Primary & Adobe S, R3 & Unphased \\
\hline LVB 75B & Adult & Female & Secondary & Adobe $\mathrm{S}, \mathrm{R} 3$ & Unphased \\
\hline LVB 76 & Adult & Female & Primary & Adobe S, R3 & $\begin{array}{l}\text { Early } \\
\text { Tlamimilolpa }\end{array}$ \\
\hline LVB 77 & Adult & Male & Primary & Adobe R3 & $\begin{array}{l}\text { Early } \\
\text { Tlamimilolpa }\end{array}$ \\
\hline LVB 78 & Adult & Female & Primary & Adobe R2 & Unphased \\
\hline
\end{tabular}




\begin{tabular}{|c|c|c|c|c|c|}
\hline Field No. Burial & Age & Sex & Type & Location in compound & Phase \\
\hline LVB 79 & Adult & & Primary & Adobe R2 & Unphased \\
\hline LVB 80 & Infant & & Primary & Adobe R2 & Unphased \\
\hline LVB 81 & Infant & & Primary & Patio 1A & Unphased \\
\hline LVB 82 & Adult & & Primary & Adobe R2 & $\begin{array}{l}\text { Late } \\
\text { Tlamimilolpa }\end{array}$ \\
\hline LVB 83A & Adult & Male & Primary & Adobe R2 & \\
\hline LVB 83B & Adult & Female & Secondary & Adobe R2 & Unphased \\
\hline LVB 84 & Infant & & Primary & Adobe R2 & Unphased \\
\hline LVB 85 & Infant & & Primary & Adobe R2 & Unphased \\
\hline LVB 86A & Adult & Female & Primary & "White Wall" R & $\begin{array}{l}\text { Late } \\
\text { Tlamimilolpa }\end{array}$ \\
\hline LVB 87 & Adult & Male & Primary & Patio 1E, R A1 & $\begin{array}{l}\text { Early } \\
\text { Tlamimilolpa }\end{array}$ \\
\hline LVB 88 & Adult & Male & Primary & Patio $1 \mathrm{E}, \mathrm{R}$ Al & $\begin{array}{l}\text { Early } \\
\text { Tlamimilolpa }\end{array}$ \\
\hline LVB 89 & Fetus & & Primary & Adobe W, R1 & Unphased \\
\hline LVB 90 & Infant & & Primary & Adobe $\mathrm{W}, \mathrm{R} 1$ & Unphased \\
\hline LVB 91 & Fetus & & Primary & Adobe $\mathrm{W}, \mathrm{R} 1$ & Unphased \\
\hline LVB 92 & Fetus & & Primary & Adobe $\mathrm{W}, \mathrm{R} 1$ & Unphased \\
\hline LVB 93A & Adult & Male & Primary & Patio 1E, R1 & Unphased \\
\hline LVB 93B & Adult & Female & Primary & Patio 1E, R1 & Early Xolalpan \\
\hline LVB 94 & Adult & Female & Secondary & Patio 1E, Room 3 & Unphased \\
\hline LVB 95 & Infant & & & Patio 1E, Room 3 & $\begin{array}{l}\text { Late } \\
\text { Tlamimilolpa }\end{array}$ \\
\hline LVB 96 & Infant & & Primary & Patio 1E, R1 & $\begin{array}{l}\text { Early } \\
\text { Tlamimilolpa }\end{array}$ \\
\hline LVB 97 & Infant & & Primary & Adobe $\mathrm{W}, \mathrm{R} 1$ & Unphased \\
\hline LVB 98 & Fetus & & Primary & Adobe W, R1 & Unphased \\
\hline LVB 99 & Infant & & Primary & Adobe W, R1 & Unphased \\
\hline LVB 100 & Adult & Female & Primary & Room 6, Patio 1S & $\begin{array}{l}\text { Early } \\
\text { Tlamimilolpa }\end{array}$ \\
\hline LVB 101 & Adult & Male & Primary & Room "white wall" & Unphased \\
\hline LVB 102 & Adult & Male & Primary & Adobe Room 1 & Unphased \\
\hline LVB 103 & Fetus & & Primary & Patio 1A & Unphased \\
\hline LVB 104 & Fetus & & Primary & Patio 1A & Unphased \\
\hline LVB 105 & Adult & Male & Primary & Room, East of wall & Unphased \\
\hline LVB 106 & Fetus & & Secondary & Adobe W, R1 & Unphased \\
\hline LVB 107 & Adult & Male & Primary & Adobe Room 2 & Unphased \\
\hline LVB 108 & Infant & & Primary & Adobe Room 3 & Unphased \\
\hline LVB 109 & Fetus & & Primary & Patio 1E, Room 2 & Unphased \\
\hline LVB 110 & Male & Primary & & Patio 1S Room 6 & $\begin{array}{l}\text { Early } \\
\text { Tlamimilolpa }\end{array}$ \\
\hline LVB 111 & Adult & Male? & Primary & Room South of wall & Unphased \\
\hline
\end{tabular}




\begin{tabular}{llllll}
\hline Field No. Burial & Age & Sex & Type & Location in compound & Phase \\
\hline LVB 112 & Adult & Female? & Primary & Patio 1S, Room 6A & Unphased \\
LVB 113 & Adult? & & Primary & Patio 1W, Room 8 & Unphased \\
LVB 114 & Adult & Male & Primary & Patio 1S, Room 6A & Late \\
& & & & & Tlamimilolpa \\
LVB 115 & Adult & Female & Primary & Adobe 1W, R1 & Unphased \\
LVB 116 & Adult & Male & Primary & Adobe 1W, R1 & Unphased \\
LVB 117 & Adult & Female & Primary & Altar Patio 1 & Unphased \\
LVB 118 & Adult & Female & Secondary & Group E, Room 1A & Unphased \\
LVB 119 & Adult & Male & Secondary & Patio 1W, Room 9A & Late Xolalpan
\end{tabular}

\section{La Ventilla B Salvage Burials}

\begin{tabular}{|c|c|c|c|c|c|}
\hline Field No. Burial & Age & Sex & Type & Location in compound (fig. 6) & Phase \\
\hline LVB I & Adult & Female & Primary & Patio 1S, Room, 6 & $\begin{array}{l}\text { Late } \\
\text { Tlamimilolpa }\end{array}$ \\
\hline LVB II & Adult & & & Patio $1 W$, Room 8 & $\begin{array}{l}\text { Late } \\
\text { Tlamimilolpa }\end{array}$ \\
\hline LVB IIIa & Adult & Male & Primary & Patio 1S, Room 6 & $\begin{array}{l}\text { Early } \\
\text { Tlamimilolpa }\end{array}$ \\
\hline LVB IIIb & Cranium & & Secondary & & \\
\hline LVB IIIc & Cranium & & Secondary & & \\
\hline LVB IV & Adult & Female & Primary & Patio 1W, Room 15 & Late Xolalpan \\
\hline LVB V & Adult & Female & & Patio 1W, Room 15 & $\begin{array}{l}\text { Late } \\
\text { Tlamimilolpa }\end{array}$ \\
\hline LVB VI & Adult & Female & Secondary & Altar Patio 1 & Unphased \\
\hline LVB VII & Adult & Female & Primary & Group E, Room 1 & Unphased \\
\hline LVB VIIIa & Adult & Male & Primary & Patio $1 \mathrm{~W}$, Room 9 & Unphased \\
\hline LVB VIIIb & Child & & Secondary & Patio $1 \mathrm{~W}$, Room 9 & Unphased \\
\hline LVB IX & Adult & Female & Primary & Patio $1 \mathrm{~W}$, Room 9 & $\begin{array}{l}\text { Early - Late } \\
\text { Tlamimilolpa }\end{array}$ \\
\hline LVB X & Adult & Female & Primary & Patio 1W, Room 20 & Unphased \\
\hline LVB XI & Adult & & & Adobe Room 2 & $\begin{array}{l}\text { Late } \\
\text { Tlamimilolpa }\end{array}$ \\
\hline LVB XIII & & & Cremation & Patio 10, Room 2 & $\begin{array}{l}\text { Late } \\
\text { Tlamimilolpa }\end{array}$ \\
\hline LVB XIV & Adult & Male & Primary & Patio $1 \mathrm{~W}$, Room Al & $\begin{array}{l}\text { Early } \\
\text { Tlamimilolpa }\end{array}$ \\
\hline LVB XVI & Adult & Male & & Patio $1 \mathrm{~W}$, Room Al & Unphased \\
\hline LVB XVII & Fetus & & Primary & Patio 5 & Unphased \\
\hline LVB XVIII & & & & Patio 5 & $\begin{array}{l}\text { Early } \\
\text { Tlamimilolpa }\end{array}$ \\
\hline LVB XIX & Fetus & & & Patio 5 & Unphased \\
\hline
\end{tabular}




\begin{tabular}{|c|c|c|c|c|c|}
\hline Field No. Burial & Age & Sex & Type & Location in compound & Phase \\
\hline LVB XX & Adult Female & & & Patio 5 & $\begin{array}{l}\text { Early } \\
\text { Tlamimilolpa }\end{array}$ \\
\hline LVB XXI & Adult & Female & & Patio 1W, Room A1 & Unphased \\
\hline LVB XXII & Adult & Male & Primary & Patio $1 \mathrm{~W}$, Room Al & Late Xolalpan \\
\hline LVB XXIII & Adult & Female & & Patio 1W, Room Al & Unphased \\
\hline LVB XXIV & & & & Patio $1 \mathrm{~W}$, Room 6 & Late Xolalpan \\
\hline LVB XXV & Adult & Female & & Patio 1W, Room 15 & $\begin{array}{l}\text { Late } \\
\text { Tlamimilolpa }\end{array}$ \\
\hline LVB XXVI & Adult & Female & & Patio $1 \mathrm{~W}$, Room 8 & Unphased \\
\hline LVB XXVII & Adult & Female & & Patio $1 \mathrm{~W}$, Room 5 & Unphased \\
\hline LVB XXVIII & Adult & Male & & Patio 1W, Room 1 & Unphased \\
\hline LVB XXIX & Youth & & & Patio 1 & Unphased \\
\hline LVB XXX & Adult & Male & Primary & Patio 1S, Room 6 & Unphased \\
\hline LVB XXXI & Adult & Female & Primary & Patio 5 & $\begin{array}{l}\text { Early } \\
\text { Tlamimilolpa }\end{array}$ \\
\hline LVB XXXII & Adult & Female & Primary & Adobe Room 2, "well" & Unphased \\
\hline LVB XXXIII & Adult & Female & Primary & Adobe Room 2, "well" & Unphased \\
\hline LVB XXXIV & Adult, aged & Female & Primary & Adobe Room 2, "well" & Unphased \\
\hline LVB XXXV & Adult & Male & Primary & Adobe Room 2, "well" & Unphased \\
\hline LVB XXXVI & Adult & Female & Primary & Adobe Room 2, "well" & Unphased \\
\hline
\end{tabular}

\section{Tetitla Apartment Compound Burials}

Field No. Burial

Te 1

Te 2

Te 3

Te 4

Te 5

Te 6

Te 7

Te 8

Te 9

Te 10

Te 11

Te 12
Adult

Male

Adult

Adult

Adult

Male

Adult

Cremation

Female
Type

Location in compound (fig. 25, 26)
Phase

Unphased

NE Temple group, west platform

NE Temple group, Patio Metepec

NE Temple group, Patio Metepec

NE Temple group, Patio Early Xolalpan

NE Temple group, Patio Late Xolalpan

NE Temple group, east room Metepec

South of NE Temple group Early Xolalpan

SW Patio, entrance

Late

Tlamimilolpa

Northeast Temple group, Late Xolalpan east platform

NE Temple group, Metepec

east platform

NE Temple group, Metepec east platform

Room east of

NE Temple group 


\begin{tabular}{|c|c|c|c|c|c|}
\hline Field No. Burial & Age & Sex & Type & Location in compound & Phase \\
\hline
\end{tabular}

\begin{tabular}{|c|c|c|c|c|}
\hline Te 13 & Youth & Male & Room, east wall & Metepec \\
\hline Te 14 & Adult & & $\begin{array}{l}\text { W Central Patio group, } \\
\text { south room }\end{array}$ & Late Xolalpan \\
\hline Te 15 & Adult & & $\begin{array}{l}\text { South room of } \\
\text { Central Patio }\end{array}$ & Late Xolalpan \\
\hline Te 16 & & & $\begin{array}{l}\text { NE Temple group, } \\
\text { east platform }\end{array}$ & Early Xolalpan \\
\hline Te 17 & Adult & & $\begin{array}{l}\text { NE Temple group, } \\
\text { east platform }\end{array}$ & $\begin{array}{l}\text { Late } \\
\text { Tlamimilolpa }\end{array}$ \\
\hline Te 18 & & & SE Temple group, patio & Late Xolalpan \\
\hline Te 19 & & & SE Temple group, patio & Late Xolalpan \\
\hline Te 20 & Adult & Male & $\begin{array}{l}\text { West Central group, } \\
\text { north room }\end{array}$ & Late Xolalpan \\
\hline Te 21 & & & NW Patio group, patio & Unphased \\
\hline Te 22 & & & Central Room with columns & Unphased \\
\hline Te 23 & & & $\begin{array}{l}\text { North Central Annex, } \\
\text { east room }\end{array}$ & Unphased \\
\hline Te 24 & Adult, Child & & $\begin{array}{l}\text { North Central Annex, } \\
\text { Center room }\end{array}$ & Unphased \\
\hline Te 25 & Adult & Female & $\begin{array}{l}\text { North Central Annex, } \\
\text { east room }\end{array}$ & Unphased \\
\hline Te 26 & Adult & Female & $\begin{array}{l}\text { North Central Annex, } \\
\text { North room }\end{array}$ & Early Xolalpan \\
\hline Te 27 & & & $\begin{array}{l}\text { North Central Annex, } \\
\text { east room }\end{array}$ & Early Xolalpan \\
\hline Te 28 & Adult & & $\begin{array}{l}\text { North Central unit, } \\
\text { East pórtico }\end{array}$ & Late Xolalpan \\
\hline Te 29 & 2 Adults & Male, Female & NW Unit, patio & Metepec \\
\hline $\mathrm{Te} 30$ & Adult & Female & NW unit, South center room & Metepec \\
\hline Te 31 & & & NE Temple group, patio & $\begin{array}{l}\text { Late } \\
\text { Tlamimilolpa }\end{array}$ \\
\hline Te 32 & Adult & & NE Temple group, plaza & Early Xolalpan \\
\hline Te 33 & Adult & & NE Annex, northeast corner & Metepec \\
\hline Te M1 & Adult, midd & & $\begin{array}{l}\text { West of Armillas' excavation } \\
\text { south room }\end{array}$ & Late Xolalpan \\
\hline
\end{tabular}


Field No. Burial

Age

Sex

Type

Location (fig. 27, 28)

Phase

Z 1

Z 2

Z 3

Z 4

Z 5

Z 6

Z 7

Z 8

Z 9

Z 10

Z 11

Z 12

Z 13

Z 14

Z 15

Z 16

Z 17

Z 18

Z 19

Z 20

Z 21

Z 22

Z 23

Z 24

Z 25

Z 26

$\mathrm{Z} 27$

Z 28

Z 29

Z 20

Z 31
Adult

Adult

5 individuals

(1 adult, 1 youth)

2 Adults

1 Male

1 Male, 1 Female

Male

Female

Male

Male

Female

Adult

Adult

Female

Adult, Child

Adult

Male

Adult, Child

Male

Adult

Male

Child

Adult

Male

Adult

Male

Adolescent

Adult

Female

Adult

Male

Adult

4 Adults, 2 Children

Female

3 Male,
Partial cremation

Zacuala Patios (fig. 27)

Zacuala Patios

Zacuala Patios

Zacuala Patios

Zacuala Patios

1 Secondary

Zacuala Patios

Zacuala Patios

Zacuala Patios

Zacuala Patios

Zacuala Patios

Zacuala Patios

Zacuala Patios

Zacuala Patios

1 Secondary Zacuala Patios

Zacuala Patios

Zacuala Patios

Zacuala Patios

Zacuala Patios

Zacuala Patios

Zacuala Patios

Zacuala Patios

Zacuala Patios

Zacuala Patios

Zacuala Patios

Zacuala Patios

Zacuala Patios

Zacuala Palace (fig. 28)

Zacuala Palace

Zacuala Palace

Zacuala Palace

1 Female

Zacuala Palace

Late Xolalpan

Late Xolalpan

Metepec

Late Xolalpan

Early Xolalpan

Late

Tlamimilolpa-

Early Xolalpan

Late Xolalpan

Metepec

Late Xolalpan

Late

Tlamimilolpa-

Early Xolalpan

Early Xolalpan

Unphased

Metepec

Unphased

Late Xolalpan

Late Xolalpan

Metepec

Unphased

Unphased

Unphased

Unphased

Unphased

Unphased

Late Xolalpan

Unphased

Metepec

Early Xolalpan

Late Xolalpan

Metepec

Early Xolalpan

Early Xolalpan 


\begin{tabular}{|c|c|c|c|c|c|}
\hline Field No. Burial & Age & Sex & Type & Location (fig. 29) & Phase \\
\hline Y1-Y3 & no data & & & Yayahuala & \\
\hline Y 4 & Adult, Child & Female & & Yayahuala & Late Xolalpan \\
\hline Y5-Y9 & no data & & & Yayahuala & \\
\hline Y 10 & Adult & $\begin{array}{l}1 \text { Female, } \\
1 \text { unknown }\end{array}$ & & Yayahuala & $\begin{array}{l}\text { Late } \\
\text { Tlamimilolpa }\end{array}$ \\
\hline Y 11 & no data & & & Yayahuala & \\
\hline Y 12 & 2 Adults & & Secondary & Yayahuala & Metepec \\
\hline Y 13 & Adult & Female & & Yayahuala & Early Xolalpan \\
\hline Y 14 & & & & Yayahuala & Early Xolalpan \\
\hline Y 15 & & & & Yayahuala & Early Xolalpan \\
\hline Y 16 & & & & Yayahuala & Early Xolalpan \\
\hline Y17-Y24 & no data & & & Yayahuala & \\
\hline Y 25 & & & & Yayahuala & $\begin{array}{l}\text { Late } \\
\text { Tlamimilolpa }\end{array}$ \\
\hline Y 26 & & & & Yayahuala & $\begin{array}{l}\text { Late } \\
\text { Tlamimilolpa }\end{array}$ \\
\hline Y-ST-1 & Adult & & Primary & $\begin{array}{l}\text { Southeast corner, } \\
\text { Rear room }\end{array}$ & Metepec \\
\hline
\end{tabular}

Tlajinga 33 Burials (Sanders, Story Widmer 1982; Storey 1987; Rattray 1983)

\begin{tabular}{|c|c|c|c|c|}
\hline Field No. Burial & Age & Type & Location in Compound, Room (fig. 8) & Phase \\
\hline TJ 1 & & Refuse & & \\
\hline TJ $2 a$ & Perinatal & Primary & 1 & Late Xolalpan \\
\hline $\mathrm{TJ} 2 \mathrm{~b}$ & Perinatal & Refuse & 1 & \\
\hline TJ 3 & Perinatal & Primary & 30 & Late Xolalpan \\
\hline $\mathrm{TJ} 4$ & \multicolumn{4}{|c|}{ Note: Belongs to Burial 3, not a separate individual (R.S.) } \\
\hline TJ 5 & Perinatal & Primary & 30 & Late Xolalpan \\
\hline TJ 6 & Adult & Primary & Courtyard 1 & Early Tlamimilolpa \\
\hline TJ 7 & Perinatal & Primary & 33 & Early Xolalpan \\
\hline TJ 8 & Perinatal & Primary & 30 & Late Xolalpan \\
\hline TJ 9 & Perinatal & Primary & Outside compound & Late Xolalpan \\
\hline TJ 10 & Perinatal & Primary & 74 & Early Tlamimilolpa \\
\hline $\mathrm{TJ} 11$ & Adult & Primary & Outside & Late Tlamimilolpa \\
\hline TJ 12 & Adult & Refuse & Courtyard 3 & Late Xolalpan \\
\hline $\mathrm{TJ} 13$ & Adult & Primary & 74 & Late Tlamimilolpa \\
\hline TJ 14 & Adult & Primary & 92 & Late Tlamimilolpa \\
\hline TJ 15 & Adult & Primary & 33 & $\begin{array}{l}\text { Late Tlamimilolpa- } \\
\text { Early Xolalpan }\end{array}$ \\
\hline
\end{tabular}




\begin{tabular}{|c|c|c|c|c|}
\hline Field No. Burial & Age & Type & Location in Compound, Room (fig. 8) & Phase \\
\hline TJ $16 \mathrm{a}$ & Adolescent & Refuse & 21 & $\begin{array}{l}\text { Early-Late } \\
\text { Tlamimilolpa }\end{array}$ \\
\hline $\mathrm{TJ} 16 \mathrm{~b}$ & Adolescent & Refuse & 21 & $\begin{array}{l}\text { Early-Late } \\
\text { Tlamimilolpa }\end{array}$ \\
\hline TJ $16 \mathrm{c}$ & Adult & Refuse & 21 & $\begin{array}{l}\text { Early-Late } \\
\text { Tlamimilolpa }\end{array}$ \\
\hline TJ $16 \mathrm{~d}$ & Adult & Refuse & 21 & $\begin{array}{l}\text { Early-Late } \\
\text { Tlamimilolpa }\end{array}$ \\
\hline TJ $16 \mathrm{e}$ & Adult & Refuse & 21 & $\begin{array}{l}\text { Early-Late } \\
\text { Tlamimilolpa }\end{array}$ \\
\hline $\mathrm{TJ} 16 \mathrm{f}$ & Adult & Refuse & 21 & $\begin{array}{l}\text { Early-Late } \\
\text { Tlamimilolpa }\end{array}$ \\
\hline TJ $16 \mathrm{~g}$ & Adult & Refuse & 21 & $\begin{array}{l}\text { Early-Late } \\
\text { Tlamimilolpa }\end{array}$ \\
\hline $\mathrm{TJ} 16 \mathrm{~h}$ & Adolescent & Refuse & 21 & $\begin{array}{l}\text { Early-Late } \\
\text { Tlamimilolpa }\end{array}$ \\
\hline $\mathrm{TJ} 16 \mathrm{i}$ & Adolescent & Refuse & 21 & $\begin{array}{l}\text { Early-Late } \\
\text { Tlamimilolpa }\end{array}$ \\
\hline TJ $17 \mathrm{a}$ & Child & Secondary & 32 & Late Xolalpan \\
\hline $\mathrm{TJ} 17 \mathrm{~b}$ & Adult & Secondary & 32 & Late Xolalpan \\
\hline TJ 18 & Adult & Secondary & 92 & Late Tlamimilolpa \\
\hline TJ 19 & Unidentifiable & Refuse & 92 & Late Tlamimilolpa \\
\hline TJ 20 & Adult & Primary & 24 & Late Xolalpan \\
\hline TJ $21 \mathrm{a}$ & Child & Primary & Courtyard 2 & Late Tlamimilolpa \\
\hline $\mathrm{TJ} 21 \mathrm{~b}$ & Infant & Primary & Courtyard 2 & Late Tlamimilolpa \\
\hline TJ $21 \mathrm{c}$ & Perinatal & Primary & Courtyard 2 & Late Tlamimilolpa \\
\hline $\mathrm{TJ} 21 \mathrm{~d}$ & Perinatal & Primary & Courtyard 2 & Late Tlamimilolpa \\
\hline TJ 22a & Adult & Refuse & Enclosed yard & Late Tlamimilolpa \\
\hline $\mathrm{TJ} 22 \mathrm{~b}$ & Adolescent & Refuse & Enclosed yard & Late Tlamimilolpa \\
\hline TJ $22 c$ & Adult & Refuse & Enclosed yard & Late Tlamimilolpa \\
\hline TJ 23 & Adult & Secondary & Enclosed yard & Late Xolalpan \\
\hline TJ 24 & Adult & Secondary & 10 & Late Xolalpan \\
\hline TJ 25 & Adult & Primary & 33 & Late Tlamimilolpa \\
\hline TJ 26 & Adult & Primary & 10 & \\
\hline
\end{tabular}

TJ 27 Note: No burial

TJ 28a

Child

TJ 28b

TJ $28 \mathrm{c}$

TJ 28d

TJ $28 \mathrm{e}$

TJ $28 \mathrm{f}$

TJ 29a

TJ 29b

Secondary

Enclosed yard

Late Tlamimilolpa

Adult

Refuse

Perinatal

Enclosed yard

Late Tlamimilolpa

Enclosed yard

Late Tlamimilolpa

Enclosed yard

Enclosed yard

Late Tlamimilolpa

Refuse

Refuse

Late Tlamimilolpa

Enclosed yard

Late Tlamimilolpa

Outside compound

Late Tlamimilolpa

Outside compound

Late Tlamimilolpa 


\begin{tabular}{|c|c|c|c|c|}
\hline Field No. Burial & Age & Type & Location in Compound Room (fig. 8) & Phase \\
\hline TJ $30 a$ & Adult & Primary & Outside compound & Late Tlamimilolpa \\
\hline $\mathrm{TJ} 30 \mathrm{~b}$ & Adult & Refuse & Outside compound & $\begin{array}{l}\text { Late Tlamimilolpa- } \\
\text { Early Xolalpan }\end{array}$ \\
\hline $\mathrm{TJ} 31$ & Perinatal & Primary & Enclosed Yard & Early Tlamimilolpa \\
\hline TJ 32 & Perinatal & Primary & 92 & Late Tlamimilolpa \\
\hline TJ 33 & Perinatal & Primary & 24 & Late Xolalpan \\
\hline $\mathrm{TJ} 34$ & Adult & Refuse & 90 & Late Xolalpan \\
\hline TJ 35 & Adult & Secondary & 84 & Late Tlamimilolpa \\
\hline TJ 36 & Perinatal & Refuse & Enclosed Yard & Late Xolalpan \\
\hline TJ 37 & Perinatal & Refuse & Enclosed Yard & Late Xolalpan \\
\hline TJ $38 \mathrm{a}$ & Child & Refuse & Enclosed Yard & Late Xolalpan \\
\hline TJ $38 \mathrm{~b}$ & Adult & Refuse & Enclosed Yard & Late Xolalpan \\
\hline TJ 39 & Perinatal & Primary & Courtyard 2 & Early Xolalpan \\
\hline TJ 40a & Perinatal & Secondary & Enclosed yard & Late Tlamimilolpa \\
\hline $\mathrm{TJ} 40 \mathrm{~b}$ & Perinatal & Refuse & Enclosed yard & Late Tlamimilolpa \\
\hline TJ 41a & Child & Secondary & Enclosed yard & Early Tlamimilolpa \\
\hline $\mathrm{TJ} 41 \mathrm{~b}$ & Perinatal & Secondary & Enclosed yard & Early Tlamimilolpa \\
\hline TJ 41c & Adult & Secondary & Enclosed yard & Early Tlamimilolpa \\
\hline TJ 41d & Child & Secondary & Enclosed yard & Early Tlamimilolpa \\
\hline TJ $41 \mathrm{e}$ & Perinatal & Refuse & Enclosed yard & Early Tlamimilolpa \\
\hline TJ 42a & Adult & Primary & Enclosed yard & Late Tlamimilolpa \\
\hline $\mathrm{TJ} 42 \mathrm{~b}$ & Adult & Primary & Enclosed yard & Late Tlamimilolpa \\
\hline TJ 43 & Adult & Primary & 103 & Early Tlamimilolpa \\
\hline $\mathrm{TJ} 44$ & Adult & Primary & 53 & Late Tlamimilolpa \\
\hline TJ $45 a$ & Adult & Secondary & 53 & Late Tlamimilolpa \\
\hline TJ $45 \mathrm{~b}$ & Adult & Secondary & 53 & Late Tlamimilolpa \\
\hline TJ 46a & Adult & Refuse & 23 & Late Tlamimilolpa \\
\hline TJ 46b & Adolescent & Refuse & 23 & Late Tlamimilolpa \\
\hline $\mathrm{TJ} 47 \mathrm{a}$ & Child & Refuse & 33 & Late Tlamimilolpa \\
\hline TJ $47 \mathrm{~b}$ & Adult & Refuse & 33 & Late Tlamimilolpa \\
\hline TJ 48 & Adolescent & Secondary & 24 & Late Xolalpan \\
\hline TJ 49 & Adult & Primary & 38 & Late Tlamimilolpa \\
\hline TJ $50 \mathrm{a}$ & Adult & Primary & Courtyard 3, Shrine & Late Xolalpan \\
\hline TJ $50 \mathrm{~b}$ & Adult & Primary & Courtyard 3, Shrine & Late Xolalpan \\
\hline TJ 50c & Adult & Primary & Courtyard 3, Shrine & Late Xolalpan \\
\hline TJ $50 \mathrm{~d}$ & Adult & Primary & Courtyard 3, Shrine & Late Xolalpan \\
\hline TJ $50 \mathrm{e}$ & Adult & Primary & Courtyard 3, Shrine & Late Xolalpan \\
\hline TJ 51 & Perinatal & Primary & 28 & Late Xolalpan \\
\hline TJ 52 & Adult & Refuse & 29 & Late Tlamimilolpa \\
\hline
\end{tabular}




\begin{tabular}{|c|c|c|c|c|}
\hline Field No. Burial & Age & Type & Location in Compound Room (fig. 8) & Phase \\
\hline TJ 53 & Adult & Refuse & 83 & Late Tlamimilolpa \\
\hline $\mathrm{TJ} 54$ & Child & Secondary & 61 & $\begin{array}{l}\text { Late Xolalpan- } \\
\text { Metepec }\end{array}$ \\
\hline $\mathrm{TJ} 55$ & Perinatal & Primary & 65 & Late Tlamimilolpa \\
\hline TJ 56 & Adult & Primary & 66 & Early Tlamimilolpa \\
\hline TJ 57 & Adult & Primary & 66 & Early Tlamimilolpa \\
\hline TJ 58 & Adult & Primary & 104 & Late Tlamimilolpa \\
\hline TJ $59 \mathrm{a}$ & Child & Primary & 44 & Early Xolalpan \\
\hline TJ $59 \mathrm{~b}$ & Adult & Refuse & 44 & Early Xolalpan \\
\hline TJ 60a & Adult & Primary & 68 & Early Tlamimilolpa \\
\hline TJ $60 \mathrm{~b}$ & Child & Primary & 68 & Late Xolalpan \\
\hline $\mathrm{TJ} 60 \mathrm{c}$ & Adult & Primary & 68 & Early Tlamimilolpa \\
\hline TJ $60 \mathrm{~d}$ & Adult & Primary & 68 & Early Tlamimilolpa \\
\hline TJ 61 & Adult & Primary & 44 & Late Xolalpan \\
\hline TJ $62 \mathrm{a}$ & Adult & Refuse & 32 & Late Tlamimilolpa \\
\hline TJ 62b & Adolescent & Refuse & 32 & Late Tlamimilolpa \\
\hline TJ $63 a$ & Adult & Refuse & 67 & Late Tlamimilolpa \\
\hline $\mathrm{TJ} 63 \mathrm{~b}$ & Adult & Refuse & 67 & Late Tlamimilolpa \\
\hline TJ 64 & Perinatal & Primary & 83 & Late Tlamimilolpa \\
\hline TJ 65 & Perinatal & Primary & 83 & Late Tlamimilolpa \\
\hline TJ 66 & Perinatal & Primary & 83 & Late Tlamimilolpa \\
\hline TJ 67 & Perinatal & Refuse & 34 & Late Tlamimilolpa \\
\hline TJ 68 & Perinatal & Secondary & Northern Walkway & Late Tlamimilolpa \\
\hline TJ 69 & Perinatal & Refuse & 21 & Late Tlamimilolpa \\
\hline TJ 70 & Adult & Secondary & 53 & Late Tlamimilolpa \\
\hline
\end{tabular}

Oaxaca Barrio Burials (Rattray 1981, 1986; Spence 1976)

\begin{tabular}{|c|c|c|c|c|c|}
\hline Field No. Burial & Age & Sex & Type & Location (fig. 11, 12, 13) & Phase \\
\hline Oax-C1 & Adult & & Secondary & Pit EIN17 & Early Xolalpan \\
\hline Oax-B1 & Adult & & Secondary & Pit WIN24 & Early Xolalpan \\
\hline Oax-A1, A2, A3 & 3 Adults & & $\begin{array}{l}2 \text { primary, } \\
1 \text { secondary }\end{array}$ & Pit WIN9- W2N9 & Late Xolalpan \\
\hline \multirow[t]{2}{*}{ Oax-Tomb } & 4 Adults & & $\begin{array}{l}2 \text { Males, } \\
1 \text { Female, } \\
1 \text { undetermined }\end{array}$ & $\begin{array}{l}\text { South central sector } \\
\text { compound }\end{array}$ & $\begin{array}{l}\text { Late Xolalpan- } \\
\text { Metepec }\end{array}$ \\
\hline & $\begin{array}{l}1 \text { Child, } \\
1 \text { Perinatal }\end{array}$ & & Secondary & & $\begin{array}{l}\text { Late Xolalpan- } \\
\text { Metepec }\end{array}$ \\
\hline
\end{tabular}




\begin{tabular}{|c|c|c|c|c|c|}
\hline Burial Field No. & Age & Sex & Type & Location (fig. 15-21) & Phase \\
\hline MB 1 & Fetus & & Secondary & $\begin{array}{l}\text { E1S2, A1 South } \\
\text { Platform, Xocotitla (fig. 15) }\end{array}$ & Late Xolalpan \\
\hline MB 2a & Perinatal & & Primary & E1N3, B3, & Early Xolalpan \\
\hline MB 2b & Mid. Adult & & Secondary & North Platform & Early Xolalpan \\
\hline MB 3a & Mid. Adult & & Cremation & Adoratorio & Late Xolalpan \\
\hline MB 3b & Mid. Adult & & Cremation & Adoratorio & Late Xolalpan \\
\hline MB 4 & Mid. Adult & & $\begin{array}{l}\text { Possible } \\
\text { Cremation }\end{array}$ & $\begin{array}{l}\text { Circular Structure } \\
\text { 2, Center }\end{array}$ & Early Xolalpan \\
\hline MB 5 & 2 Perinatals & & Secondary & $\begin{array}{l}\text { Circular Structure } 2 \\
\text { East ramp }\end{array}$ & Early Xolalpan \\
\hline MB 5 & 7 Infants & & Secondary & $\begin{array}{l}\text { Circular Structure } 2 \\
\text { East ramp }\end{array}$ & Early Xolalpan \\
\hline MB 5 & 3 Youths & & Secondary & $\begin{array}{l}\text { Circular Structure } 2 \\
\text { East ramp }\end{array}$ & Early Xolalpan \\
\hline MB 5 & 3 Sub-adults & 1 Male & Secondary & $\begin{array}{l}\text { Circular Structure } 2 \\
\text { East ramp }\end{array}$ & Early Xolalpan \\
\hline MB 5 & 5 Young Adults & 3 Female, 2 Male & Secondary & $\begin{array}{l}\text { Circular Structure } 2 \\
\text { East ramp }\end{array}$ & Early Xolalpan \\
\hline MB 5 & 1 Young Adult & Female & Primary & $\begin{array}{l}\text { Circular Structure } 2 \\
\text { East ramp }\end{array}$ & Early Xolalpan \\
\hline MB 5 & 9 Mid. Adults & 3 Female, 4 Male & Secondary & $\begin{array}{l}\text { Circular Structure } 2 \\
\text { East ramp }\end{array}$ & Early Xolalpan \\
\hline MB 5 & 4 Aged & 1 Female, 2 Male & Secondary & $\begin{array}{l}\text { Circular Structure } 2 \\
\text { East ramp }\end{array}$ & Early Xolalpan \\
\hline MB 9 & Child & & Secondary & Circular Structure 3 & $\begin{array}{l}\text { Late } \\
\text { Tlamimilolpa }\end{array}$ \\
\hline MB 10a & Young Adult & Male & Primary & Circular Structure 4 & $\begin{array}{l}\text { Late Xolalpan- } \\
\text { Metepec }\end{array}$ \\
\hline MB $10 \mathrm{~b}$ & Fetus & & Primary & Circular Structure 4 & $\begin{array}{l}\text { Late Xolalpan- } \\
\text { Metepec }\end{array}$ \\
\hline MB $10 \mathrm{c}$ & Child & & Primary & Circular Structure 4 & $\begin{array}{l}\text { Late Xolalpan- } \\
\text { Metepec }\end{array}$ \\
\hline MB 11a & Young Adult & Male & Primary & Circular Structure 4 & $\begin{array}{l}\text { Late Xolalpan- } \\
\text { Metepec }\end{array}$ \\
\hline MB $11 \mathrm{~b}$ & Child & Male & Primary & Circular Structure 4 & $\begin{array}{l}\text { Late Xolalpan- } \\
\text { Metepec }\end{array}$ \\
\hline MB 12 & Young Adult & Female & Primary & Circular Structure 4 & $\begin{array}{l}\text { Late Xolalpan- } \\
\text { Metepec }\end{array}$ \\
\hline MB 13a & Fetus & & & Shaft tomb, Structure 4 & Late Xolalpan \\
\hline MB 13b & Young Adult & Female & & & Late Xolalpan \\
\hline MB 14a & Fetus & & & Adoratorio 2 (fig. 21) & Early Xolalpan \\
\hline MB 14b & Young Adult & Female & & Adoratorio 2 & Early Xolalpan \\
\hline MB 14c & Mid. Adult & Male & & Adoratorio 2 & Early Xolalpan \\
\hline MB $14 d$ & Child & Male & & Adoratorio 2 & Early Xolalpan \\
\hline
\end{tabular}




\begin{tabular}{|c|c|c|c|c|c|}
\hline Burial Field No. & Age & Sex & Type & Location (fig. 15-21) & Phase \\
\hline MB $14 \mathrm{e}$ & Mid. Adult & Female & & Adoratorio 2 (fig. 21) & Early Xolalpan \\
\hline MB 15-16 & Adult & Male & & Platform W3N2-W2N2 (fig. 15) & Late Xolalpan \\
\hline MB 17a & Mid. Adult & Female & & Adoratorio 2 & Late Xolalpan \\
\hline MB $17 \mathrm{~b}$ & Mid. Adult & Female & & Adoratorio 2 & Late Xolalpan \\
\hline MB 18 & Fetus & & & Adoratorio 2 & Late Xolalpan \\
\hline MB 19 & Middle Adult & Male & & Platform W3S1 (fig. 15) & $\begin{array}{l}\text { Early-Late } \\
\text { Xolalpan }\end{array}$ \\
\hline MB 20-21 & Unidentified & & Secondary & $\begin{array}{l}\text { Circular Structure 10, } \\
\text { Adoratorio } 4 \text { Mezquititla } \\
\text { (fig. 16) }\end{array}$ & $\begin{array}{l}\text { Late } \\
\text { Tlamimilolpa }\end{array}$ \\
\hline MB 22a & Young Adult & & Secondary & Patio, Mezquititla (fig. 16,18 ) & $\begin{array}{l}\text { Late } \\
\text { Tlamimilolpa }\end{array}$ \\
\hline MB 22b & Child & & Secondary & Patio, Mezquititla & $\begin{array}{l}\text { Late } \\
\text { Tlamimilolpa }\end{array}$ \\
\hline MB 23 & Unidentified & & Secondary & Patio, Mezquititla & $\begin{array}{l}\text { Late } \\
\text { Tlamimilolpa }\end{array}$ \\
\hline MB 24-25a & Aged & Male & & Structure 12 , Xocotitla (fig. 15) & Early Xolalpan \\
\hline MB 24-25b & Mid. Adult & Male & & Adoratorio 3, Xocotitla & Early Xolalpan \\
\hline MB 24-25c & Aged & Male & & Adoratorio 3, Xocotitla & Early Xolalpan \\
\hline MB 24-25d & Young Adult & Female & & Adoratorio 3, Xocotitla & Early Xolalpan \\
\hline MB 26 & Mid. Adult & Female & & Adoratorio 3, Xocotitla & Early Xolalpan \\
\hline MB 27a & Fetus & & Secondary & $\begin{array}{l}\text { Patio Circular Structure } \\
12\end{array}$ & Early Xolalpan \\
\hline MB 27b & Infant & & Secondary & $\begin{array}{l}\text { Patio Circular Structure } \\
12\end{array}$ & Early Xolalpan \\
\hline MB 28 & Aged & Female & Secondary & Adoratorio 3 & Early Xolalpan \\
\hline MB 29 & Child & & Secondary & Adoratorio 3 & Early Xolalpan \\
\hline MB 30a & Young Adult & Female & & Adoratorio 3 & Unphased \\
\hline MB 30b & Fetus & & & Adoratorio 3 & Unphased \\
\hline MB 31 & Mid. Adult & & & Adoratorio 3 & Unphased \\
\hline MB 32 & Mid. Adult & Male & & Patio & Unphased \\
\hline MB 33a & Mid. Adult & Male & & $\begin{array}{l}\text { Structure 15, Nopalera } \\
\text { (fig. 17) }\end{array}$ & Late Xolalpan \\
\hline MB 33b & Young Adult & Male & & Structure 15 , Nopalera & Late Xolalpan \\
\hline MB 34a & Young Adult & Male & & Nopalera & Late Xolalpan \\
\hline MB 34b & Young Adult & Female & & Nopalera & Late Xolalpan \\
\hline MB 34c & Fetus & & & Nopalera & Late Xolalpan \\
\hline MB 35 & Mid. Adult & Male & & Adoratorio 5 (fig. 16) & Unphased \\
\hline
\end{tabular}




\begin{tabular}{lrrrr}
\hline Burial Field No. & Age & Sex & Type & Location \\
\hline PT 6 & & & Site 57, Pit 1 & Phase \\
PT 8 & Fetus & & Site 57, Pit 2 & Metepec \\
& & & Early \\
Tlamimilolpa
\end{tabular}

Teotihuacan Archaeological Project 1980-1982 (INAH) (González M. and D. Fuentes G., 1982;

González M. y Salas Cuesta, M. 1990)

\begin{tabular}{|c|c|c|c|}
\hline Burial Field No. & Age & Type & Location \\
\hline PAT & Burials 4-11 Burials 21-22 & $\begin{array}{l}2 \text { primary } \\
8 \text { secondary }\end{array}$ & $\begin{array}{l}\text { Semi-circular Structures, Great Rectangle } \\
\text { Semi-circular Structures, Great Rectangle }\end{array}$ \\
\hline PAT & Burials 1-3 Burials 12-20, 23-113 & & $\begin{array}{l}\text { Ciudadela, Calle de los Muertos, Great } \\
\text { Rectangle and Northeast Compound } \\
\text { (González, et. al 1982:421) } \\
\text { Ciudadela, Calle de los Muertos, Great } \\
\text { Rectangleand Northeast Compound } \\
\text { (González, et. al 1982: 421) }\end{array}$ \\
\hline
\end{tabular}


Number of

Burials

OS-Ostoyahualco

PP-Pueblo Perdido

Q-Temple of Quetzalcoatl

TL-Tlamimilolpa

XO-Xolalpan

EX-Extraordinary Find

LVA-La Ventilla A

LVB-La Ventilla B

Te-Tetitla

Z-Zacuala

Y-Yayahuala

TJ-Tlajinga 33

Oax-Oaxaca Barrio Tomb

MB-Merchants' Barrio

PT-Prouecto Teotihuacan 60-64

PAT-Proyecto Arqueológico Teotihuacan 80-82
Number of

Individuals

$\begin{array}{rc}11 & 12 \\ 1 & 1 \\ 6 & 26 \\ 18 & 18 \\ 7 & 7 \\ 1 & 1 \\ 11 & 11 \\ 152 & 160 \\ 34 & 36 \\ 31 & 45 \\ 27 & 27 \\ 68 & 107 \\ 4 & 11 \\ 35 & 80 \\ 2 & 261 \text { individuals } \\ 113 & \end{array}$

